\title{
NEW TASKS AND DIRECTIONS FOR THE DEVELOPMENT OF JURIDICAL SCIENCE IN XXI CENTURY
}

Collective monograph

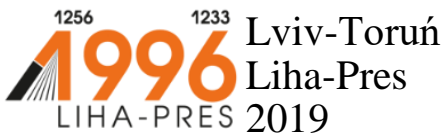




\section{Reviewers:}

Prof. dr hab. Sabina Grabowska, Uniwersytet Rzeszowski / University of Rzeszow (Republic of Poland);

Prof. dr hab. Joanna Marszalek-Kawa, Uniwersytet Mikotaja Kopernika w Toruniu / Nicolaus Copernicus University (Republic of Poland).

New tasks and directions for the development of juridical science in XXI century : collective monograph / S. S. Andreichenko, G. V. Chebotareva, A. V. Denysova, L. V. Didenko, etc. - Lviv-Toruń : Liha-Pres, 2019. $-328 \mathrm{p}$.

ISBN 978-966-397-178-0

Liha-Pres is an international publishing house which belongs to the category "C" according to the classification of Research School for Socio-Economic and Natural Sciences of the Environment (SENSE) [isn: 3943, 1705, 1704, 1703, 1702, 1701; prefixMetCode: 978966397]. Official website www.sense.nl. 


\section{CONTENTS}

THEORETICAL-CONCEPTUAL UNDERSTANDING

OF CATEGORIES "GUILT", "ATTRIBUTION"

AND "IMPUTATION" FOR THE PURPOSES

OF INTERNATIONAL RESPONSIBILITY OF THE STATE

Andreichenko S. S....................................................................................................1

PROBLEMS OF LEGAL REGULATION

OF THE STATE SERVICE OF UKRAINE

Chebotareva G. V.

PLACE OF ADMINISTRATIVE SUPERVISION

IN THE ACTIVITIES OF THE EXECUTIVE POWER

OF UKRAINE

Denysova A. $\mathrm{V}$.

THE RATIO OF THE CIVIL AND CIVIL-PROCEDURAL

LEGAL RELATIONS IN THE SCIENCE OF CIVIL

PROCEDURAL LAW

Didenko L. V.

COMBATING CRIMINAL LAW COMPLICITY

IN THE CRIME

Dombrovan N. V. .66

LEGAL STATUS OF THE CHIEF OF THE NATIONAL POLICE DEPARTMENT OF UKRAINE

Izbash K. S .86

VOLUNTARY INSTRUMENTS IN THE SPHERE OF PRODUCTION IN EUROPEAN UNION LAW AND THEIR IMPORTANCE TO UKRAINE

Kachuriner V. L.........................................................................................104

CRIME IN EPISTEMOLOGICAL-AXIOLOGICAL CONTEXT PARADIGMS OF QUALIFICATION AND COMPOSITION

Klyuev O. M. 
THE LEGAL ORDER AS A FACTOR OF INVESTMENT ATTRACTIVENESS OF UKRAINE FOR DOMESTIC AND FOREIGN ENTREPRENEURS

Kryzhanovskii A. F. 143

JURIDICAL ACTIVITY AS A SPECIAL AREA

FOR THE APPLICATION OF JURIDICAL ALGORITHMS

Manko D. G.

METHODS OF PUBLIC ADMINISTRATION

Nenko S. S. 175

OFFENSES RELATED OF GOODS / ITEMS ACROSS

THE CUSTOMS BORDER: NATURE AND BUSSINES

COMPONENT

Palamarchuk G. V., Neledva N. V.

THE SUBJECTS OF THE ADMINISTRATIVE PROCESS

Popovich Ye. M. 208

PROCEEDINGS FOR CONSIDERATION

OF CITIZEN'S APPEALS

Predmestnikov O. G.

ORGANIZATION OF ACTIVITIES OF PATROL POLICE, SECURITY POLICE AND SPECIAL PURPOSE POLICE

Rachinska I. M. 254

LEGAL SIGNIFICANCE OF THE CONCEPT

"ACADEMIC INTEGRITY"

Tytska Ya. O. 278

CONCEPT, PROPERTIES AND PRINCIPLES

OF ADMINISTRATIVE RESPONSIBILITY

Voronin Ya. G.

EVOLUTION OF THE HIGHER EDUCATION ISSUES

IN THE INTERNATIONAL TREATIES

Hromovenko K. V. 304 


\section{THEORETICAL-CONCEPTUAL UNDERSTANDING OF CATEGORIES “GUILT”, “ATTRIBUTION" AND "IMPUTATION" FOR THE PURPOSES OF INTERNATIONAL RESPONSIBILITY OF THE STATE}

\section{Andreichenko S. S.}

\section{INTRODUCTION}

The effectiveness of international law as of a socially necessary instrument for international relations regulating depends crucially on the States' strict adherence to their international obligations. The implementation and application of the rules of law have long been of particular importance, which is confirmed by the postulates executio est finis et fructus legis (An execution is the end and the fruit of the law) and applicatio est vita regalae (The application is the life of a rule). Conscientious implementation of international obligations is a criterion for the legitimacy of the activities of States in international and domestic spheres and it is a necessary condition for stability and efficiency of international law and order. However, the problem of the effectiveness of the rules of international law, which has been acutely and widely discussed throughout history and considered to be the most vulnerable side of international law, remains one of its central problems today.

The task of enhancing of the effectiveness of international law is largely entrusted with international responsibility, which plays a fundamental role in the current system of international law while demonstrating the level of its unity and stability.

The issue of State responsibility has received much attention in international legal literature. Some aspects of responsibility of States for their internationally wrongful acts have been considered in the works of such Ukrainian international lawyers as Y.Y. Blazhevych, M.V. Buromenskyi, V.H. Butkevych, A.I. Dmytriiev, N.A. Zelinska, I.I. Lukashuk, V.V. Mytsyk, L.D. Tymchenko, Y.S. Shemshuchenko and other.

A significant contribution to the development of responsibility problems was made by the works of Soviet scientists: V.A. Vasylenko, Y.M. Kolosov, P.M. Kuris, D.B. Levin, S.B. Petrovskyi, S.B. Raskalei, H.I. Tunkin and others. Foreign authors who devoted their issues to international legal responsibility are Roberto Ago, Dionisio Anzilotti, Ian Brownlie, Antonio Cassese, James Crawford, Lassa Oppenheim, Alain Pellet, Alfred Verdross, Malcolm Nathan Shaw and other. 
At the same time, many important aspects of international responsibility issues have not yet become the subject of special study in contemporary Ukrainian science of international law and have been partially disclosed by foreign scholars. Thus, the further study of one of the most contentious issues in the area of international responsibility, the issue of State guilt, is relevant.

\section{Category "guilt" of State in international law: the essential characteristic}

The notion that "guilt" is relevant in international law is shared by most of international lawyers. At the same time, the problem of guilt is perhaps the most complex in the whole theory of international responsibility law. The fact that the issue of State guilt has proven to be one of the most controversial areas of international responsibility has been repeatedly emphasized in the writings of many researchers. For example, D. Anzilotti wrote: "Generally, disputes regarding the theory of guilt and certain aspects of its application in international law have long existed and remain exist. While some authors support the theory of guilt providing it with an interpretation that differs significantly from the one given in internal law (Hatschek), others deny this theory without hesitation (Diena). Some authors also allow the notion of guilt only to identify certain categories of misconduct, in particular, the so-called "neglect torts" in general (Strupp) or some of them specifically (Schoen). Finally, some authors acknowledge that the notion of guilt is necessary to determine certain consequences, such as an obligation to compensate for harm, whereas this notion is unnecessary in simple satisfaction (Triepel), or believe that it is necessary in satisfaction, but not in compensation for damage suffered by patrimonial property (Iess)" $"$.

Some scientists have raised doubts about the possibility of using the concept of guilt to characterize the actions of the state. In one of his writings, V.M. Yelynychev concluded that an analysis of the state's behavior through the concept of guilt is not only optional but also largely redundant and harmful, as it raises a minor issue in the first place and allows the delinquent state to challenge the lawfulness of its liability (which it bears from the moment of committing the delict) by reference to the lack or unintentional intent or negligence on the part of its authorities ${ }^{2}$. From the perspective of other authors, "the guilt is a complex concept that can hardly be applied to the state at all, but proving the guilt of the state for its responsibility for

${ }^{1}$ Анцилотти Д. Курс международного права : введение - общая часть ; пер. с итал. ; под ред. : Д. Б. Левин (Предисл.) ; пер. : А. Л. Сакетти, Э. М. Фабриков. М. : Иностр. лит., 1961. T. 1. C. 415.

${ }^{2}$ Елынычев В. Н. Вина в международном праве. Советское государство и право. 1972. № 3. C. 127. 
internationally wrongful acts is optional, but this does not mean the absence of such guilt as the State's guilt presumes" ${ }^{3}$.

Note that in the process of codification, the idea of developing a general rule of guilt was repeatedly criticized by authoritative authors for being too large. The topic was considered to be too heterogeneous to regulate individual norms.

The International Law Commission, in view of the differences and debates, including the difficulty of proving guilt, did not include the guilt in the wrongful act as a necessary element. Another reason for not including the topic of guilt in the draft articles of the ILC was the inconsistency of jurisprudence in the area of state responsibility. The jurisprudence on this issue has always been different, and international courts and arbitrations have largely been unwilling, or at least incapable, of resolving this issue in principle.

Thus, the International Law Commission avoided a clear solution to the question of the place of guilt in the system of rules on international responsibility of States. The The Commission decided not to stop on the position, which was produced by the long-standing academic debate, and began to consider the problem of guilt in a pragmatic way, according to which the guilt is a circumstance, the absence of which must be proved by the defendant State in order to exclude the wrongfulness of its conduct ${ }^{4}$.

Despite the contradictions about the concept of "guilt", in the theory and practice of international law, this concept is used quite often, since it is inherently related to such fundamental categories as international offenses and international responsibility. In particular, the notion of guilt of the State, with reference to its two forms (intent and negligence), is featured in important diplomatic documents. For example, when considering in the Third Committee of the Third Commission of the UN Conference in San Francisco the provisions of Chapter VII of the Charter of the United Nations on threats to the peace, breaches of the peace, or acts of aggression the proposal from the report about "the costs of coercive action against the guilty State fell upon that State" was adopted. This proposal was unanimously approved at the plenary session of the conference ${ }^{5}$.

Provisions on guilt are found in many international courts, arbitrations, and conciliation commissions ${ }^{6}$. Links to guilt can also be found in a number

\footnotetext{
${ }^{3}$ Міжнародне право : [підручник] / Ліпкан В. А., Антипенко В. Ф., Акулов С. О. та ін. / заг. ред. В. А. Ліпкана. К. : КНТ, 2009. С. 249.

${ }^{4}$ Gattini A. Smoking / No Smoking : Some Remarks on the Current Place of Fault in the ILC Draft Articles on State Responsibility/l European Journal of International Law. 1999. Vol. 10. P. 397.

5 Левин Д. Б. Ответственность государств в современном международном праве. М. : Междунар. отношения, 1966. С. 56.

${ }^{6}$ Ref., for instance, cases: Alabama claims of the United States of America against Great Britain (1871) // Reports of International Arbitral Awards. Vol. XXIX. P. 125-134 ; United States v. Great Britain (Home Missionary Society Case) (1920) // Reports of International Arbitral
} 
of international treaties, in particular Art. 54 of Convention respecting the Laws and Customs of War on Land $(1907)^{7}$, Art. 2 of Convention on the Prevention and Punishment of the Crime of Genocide $(1948)^{8}$, Convention for the Unification of Certain Rules Relating to International Carriage by Air $(1929)^{9}$ and other.

It follows from the above mentioned that the guilt category in both its forms is uniquely applicable to the States. The presence of specific attributes of the State's guilt in international law in comparison with the guilt of certain individuals in internal law cannot be a reason for neglecting the concept of guilt relative to the State.

The notion of guilt as well as its application in international law has its own specific features that distinguishes it from the guilt in internal (criminal or civil) law. Let's try to distinguish several of such characteristics.

1) The guilt as a separate institution of international law has its own peculiarities connected with the peculiarities of international law itself and international relations to which it is directed.

2) The State's guilt is not a psychic attitude to behavior, which is committing.

3) The guilt is a manifestation of state will.

4) The State's guilt is not equated with the guilt of its separate bodies: legislative, executive, judicial, both central and local.

5) The degree of guilt can be essential for the onset of international responsibility of the State.

6) The State's guilt is not proved in all cases but only when it is explicitly provided by the primary norms (genocide, aggression).

Awards. Vol. VI. P. 42-44 ; Award between the United States and the United Kingdom relating to the rights of jurisdiction of United States in the Bering's sea and the preservation of fur seals (1893) // Reports of International Arbitral Awards. Vol. XXVIII. P. 263-276 ; Casablanca Arbitration (France v. Germany) (1909) // The American Journal of International Law. Jul., 1909. Vol. 3. № 3. P. 755-760; Award in the Matter of the Cadenhead Case (1914) // The American Journal of International Law. Jul., 1914. Vol. 8. № 3. P. 663-665 ; B. E. Chattin (United States) v. United Mexican (1927) // Reports of International Arbitral Awards. Vol. IV. P. 282-312; In the matter of the death of James Pugh (Great Britain, Panama) (1933) // Reports of International Arbitral Awards. Vol. III. P. 1439-1453; Loizidou v. Turkey. ECHR Judgment of 18 December 1996 // EHRR. Vol. 23. P. 513 та ін.

${ }^{7}$ Convention (IV) respecting the Laws and Customs of War on Land and its annex : Regulations concerning the Laws and Customs of War on Land (1907) URL: http://avalon.law.yale.edu/20th_century/hague04.asp.

${ }^{8}$ Convention on the Prevention and Punishment of the Crime of Genocide (1948) URL: http://www.hrweb.org/legal/genocide.html.

${ }^{9}$ Convention for the Unification of Certain Rules Relating to International Carriage by Air (1929) URL: http://www.jus.uio.no/lm/air.carriage.warsaw.convention.1929/doc.html. 


\section{The relation between the concepts of imputation and attribution}

For the onset of an international responsibility of the State, in addition to committing wrongful acts, another important condition must be fulfilled, namely: the subject of the obligation must be legally charged with wrongful conduct ("imputation"). Article 2 of the Articles on Responsibility of States for Internationally Wrongful Acts specifies that the necessary element for determining the existence of an internationally wrongful act is the State's behavior, which does not comply with its international obligations. As stated in the award of the international arbitration tribunal, established under the Convention on the Settlement of Investment Disputes, in the case of Gustav F. W. Hamester GmbH \& Co KG v. Republic of Ghana (2010), "Article 2 is not an independent basis for attribution, but merely provides for the elements of determining the internationally wrongful act of a State, which must be attributed to the State and violate the State's international obligation" $"$.

C. Eustathiades emphasizes that in international delict a distinction is made between an objective element, an action or omission that is a known behavior, and a subjective element arising from the perpetration of the conduct of the subject of the law ${ }^{11}$.

Familiarization with the work of the Commission, as well as with international legal literature, leads to the conclusion that the essence of the guilt, its theoretical justification due to various reasons became an obstacle for international lawyers, which caused the most controversial opinions. As a result, the problem of imputation has been largely confused ${ }^{12}$.

What does the "imputation" condition of a particular State's conduct as a requirement to qualify it as an internationally wrongful act? In scientific works on international responsibility, court decisions and in the practices of States the term "imputation" is used to indicate that a particular act is a State activity.

M. Marinoni rightly concluded, "States, as well as legal entities, cannot but resort to the actions of individuals whose activities must be legally related to the States themselves... In reality, there is no legal entity "state", but only the actions and wills of the persons, which by nomocracy are assigned to the subject of law of

${ }^{10}$ Gustav F. W. Hamester GmbH \& Co KG v. Republic of Ghana. ICSID. Case № ARB/07/24. Award. 18 June 2010. Para. 173 URL: http://www.italaw.com/documents/ Hamesterv.GhanaAward.pdf.

${ }^{11}$ Eustathiades C. Th. Les sujets du droit international et la responsabilité internationale : Nouvelles tendances / C. Th. Eustathiades / Recueil des Cours de l'Académie de droit international. T. 84. 1953-III. Leyden, Sijthoff, 1955. P. 422.

${ }^{12}$ Елынычев В. Н. Проблема вменения в международном праве. Правоведение. 1970. № 5 . C. 83 . 
the other than the natural person who is their executor"13. As K. Strupp emphasized, "the state requires individuals... whose will and behavior in the physical natural world are the actions of individuals, but in the legal world they are the actions of the community as a whole, that is, of the state"14.

From G. Kreijen's perspective, without government agencies and agents imputation, which is actually "attribution", becomes impossible. Without reference to the author of the act, there can be no liability for internationally wrongful acts. Without responsibility, international law loses its meaning as a mechanism that ensures international stability and order ${ }^{15}$.

Experts in international law have repeatedly emphasized that the term "imputation" in international law does not have the same meaning as, for example, in internal criminal law, where it may mean the mental properties of a person.

The concept of "imputation", which is used in international law, has significant differences from the similar concept used in internal legal systems. The provision set out by Special Rapporteur R. Ago in his third report on International Responsibility of States was of fundamental importance: "International law scientists have long sought to emphasize that those who use these terms in the area of international responsibility of States do not seek to attach a meaning corresponding to the meaning given, for example, in internal criminal law, where the term "imputability" is sometimes understood as a moral state, the possibility of perception and manifestation of desire on the part of the subject as the basis of responsibility and where "imputation" can be understood as a charge brought against a person by the judiciary"16.

The Commission was extremely keen to avoid the ambiguity that different perceptions of these concepts may cause in certain systems of internal criminal law. For this very reason, at the end of the discussion of the second report on the responsibility of States at the twenty-second session, the Commission at the suggestion of some of its members, in particular of M.O. Ushakov, concluded on the advisability of not using the terms

${ }^{13}$ Marinoni M. La responsabilita degli Stati per gli atti dei low rappresentanti secondo il diritto internazionale / M. Marinoni. Rome, Arthenaeum, 1913. Р. 33. Цит по : Second report on State responsibility by Roberto Ago, Special Rapporteur. The origin international responsibility A/CN.4/233 // Extract from the Yearbook of the International Law Commission. 1970. Vol. II. P. 189.

${ }^{14}$ Strupp K. Das volkerrechtliche Delikt. Handbuch des Volkerrechts. Stuttgart, Verlag von K. Kohlhammer, 1920. Bd. III, 1st abt. P. 35-36.

15 Kreijen G. State failure, sovereignty and effectiveness: legal lessons from the decolonization of Sub-Saharan Africa. Leiden; Boston : M. Nijhoff, 2004. P. 273.

16 Third Report on State responsibility, by Mr. Roberto Ago, Special Rapporteur, the internationally wrongful act of the State, source of international responsibility. A/CN.4/246 and Add.1-3 // Yearbook of the International Law Commission. 1971. Vol. II, Part One. P. 214. 
"imputation", "imputability" and the use of the term "attribution" to statement of fact of attribution of action or inaction to the state. As Professor N.A. Zelinska points out, "it is very telling that the terms "guilt" and "imputation" were not used in the proposed draft articles in respect of the State's responsibility" ${ }^{\prime 17}$.

The fact that the term "imputation" has a different meaning than the general sense of the term, which connects wrongful action or omission of its performer, D. Anzilotti wrote in his first work, which dealt with the international responsibility ${ }^{18}$. The author stressed that the meaning of the term "imputation" in international law does not correspond in any way to the content that is embedded in it in internal law, when imputation means the mental state of the agent as a basis of responsibility. When it comes to imputation on the State, it simply means that the international legal order treats actions or omissions as actions of a particular State... Then, since the state as a legal entity is physically incapable of acting, it is obvious that all that can be imputed on the State is the action or omission of individuals or groups of individuals ${ }^{19}$.

At the $25^{\text {th }}$ session of the ILC in 1975, it was stated that the term "attribution" in international law is in essence analogous to the term "imputation" used in internal law. However, there is no unambiguous opinion as to what is the term to indicate the relationship between the act and the entity in international law. The International Law Commission, like some authors, opposes the transfer of the term "imputation" from national law. Primarily, this is again due to the fact that in national law the term is used in a different meaning and is related to the concept of guilt. The ILC also believes that the term "imputation" has some criminal law connotation, so it would be more appropriate to use the term "attribution"20.

The commentary on Articles of 2001 explains: "... the term "attribution" is used to refer to an operation of attribution of a particular action or omission to a State. International practice and judgments also use the term "imputation"

17 Зелинская Н. А. Международные преступления и международная преступность : [монография]. Одесса : Юридическая литература, 2006. С. 89.

${ }^{18}$ Second report on State responsibility by Roberto Ago, Special Rapporteur. The origin international responsibility A/CN.4/233 // Extract from the Yearbook of the International Law Commission. 1970. Vol. II. P. 189.

${ }^{19}$ Second report on State responsibility by Roberto Ago, Special Rapporteur. The origin international responsibility A/CN.4/233 // Extract from the Yearbook of the International Law Commission. 1970. Vol. II. P. 189.

${ }^{20}$ Report of the International Law Commission on the work of its twenty-fifth session, 7 May - 13 July 1973. UN Doc. A/9010/Rev.1 Official Records of the General Assembly. Twenty-eighth session. Supplement № 10 // Extract from the Yearbook of the International Law Commission. 1973. Vol. II. P. 165. 
as, for instance, Diplomatic and Consular Staff (1980), Military and Paramilitary Activities (1986). However, the term "attribution" makes possible to avoid any suggestion that procedural actions, which attribute behavior to a State, are fiction or that the conduct in question is in fact the behavior of another entity ${ }^{21}$.

According to V.D. Vadaplas, "the Commission's rejection of the term "imputation" and its replacement with the term "attribution" "is decisive, allowing thus to avoid the previously known semantic confusion when the imputation for the action of the State was without any reason associated with the accusation of the judiciary in the internal state law ${ }^{22}$.

According to V.A. Vasylenko, assignment (attribution or imputation) is not only closely linked to the guilt of the States, but is a system of procedural actions for its establishment. Respectively, the clarification of peculiarities of attribution or imputation process reveals the specific nature of the guilt of delinquent State and determines the procedure for its establishment. And the main thing here is not in the terminology, but in the nature of the legal relations caused by the internationally wrongful $\mathrm{act}^{23}$.

An indication that imputation is regarded as attributing the actions of individuals to the State is also contained in the jurisprudence of states. For example, in the advisory opinion of the Permanent Court of International Justice in the case of German settlers in Poland in 1923, it was stated that the "action of the State" should include action or omission of whichever person or group of persons: "States can act only with or through their agents or representatives". Imputation is the means by which liability for wrongful acts is applied to the $\mathrm{State}^{24}$. In the conclusion mentioned above, the court ruled that the Polish Government under the Minority Treaty had an obligation to take measures "to ensure full protection of life and freedom for all Polish citizens regardless of their birth, nationality, language, race or religion."

The Court found that the eviction of German settlers from Poland would violate the State's obligations under the Minority Treaty, especially the property rights of the German minority in Poland.

${ }^{21}$ Commentaries to the draft articles on Responsibility of States for internationally wrongful acts adopted by the International Law Commission at its fifty-third session (2001). Report of the Commission to the General Assembly on the work of its fifty-third session // Yearbook of the International Law Commission. 2001. Vol. II, Part Two. P. 36.

22 Вадаплас В. Д. Развитие института международно-правовой ответственности // Международное право в современном мире : сб. ст./ отв. ред. Ю. М. Колосов. М. : Международные отношения, 1991. С. 41-51.

${ }^{23}$ Василенко В. А. Ответственность государства за международные правонарушения. Киев : Вища школа, 1976. С. 156.

${ }^{24}$ Settlers in Poland. Advisory Opinion of 10 September 1923 // PCIJ - Series B. № 6. URL: http://www.icj-cij.org/pcij/serie_B/B_06/Colons_allemands_en_Pologne_Avis_consultatif.pdf. 
In the case of Dickson Car Wheel Company (U.S.A.) v. United Mexican States (1931) the General Claims Commission (Mexico and United States) noted in its award: "Under international law, apart from any convention, in order that a State may incur responsibility it is necessary that an unlawful international act be imputed to it, that is, that there exist a violation of a duty imposed by an international juridical standard" 25 .

When examining the nature and meaning of the category "imputation" on the State, one should also present the positions of jurists who do not consider it necessary to impute the unlawful actions or omissions of individuals or legal entities before it is found responsible for violating the principles and rules of international law.

I. Brownlie comes from the assertion that "generally broad formulas of State responsibility are of little use and they are simply misleading when internal law analogies arise. Thus, it is often said that responsibility arises only when the contested action or omission can be imputed on the State. Imputation is a superfluous notion since the main question in a particular situation is whether there is a breach of duty. The content of the imputation varies depending on the specific duty, the nature of the offense, etc. Imputation generates fiction in cases, where there is no guilt, and suggests a substitute (derivative) responsibility, when the latter is not applicable..."26 Moreover, in one of his later works I. Brownlie stated, "The concept of imputation is a source of unnecessary difficulty and should be avoided"27.

In our opinion, the statements made by opponents of imputation theory are not sufficiently convincing. We cannot agree that imputation is a "needless" or "superfluous" concept. Imputation is one of the prerequisites for the existence of international responsibility, since in order to put the mechanism of international responsibility into effect, it is necessary to determine whether the action or omission was committed by a State. Imputation is an integral and inevitable component in the mechanism of recognition of a State's responsibility for breach of international obligations.

Thus, attribution provisions are prominent in international law. The main reason is that States can act only through individuals and legal entities and without the application of proper attribution mechanism States will not be a subject to international liability for specific misconduct.

${ }^{25}$ Dickson Car Wheel Company (U.S.A.) v. United Mexican States (1931)// Reports of International Arbitral Awards. Vol. IV. P. 669-691.

${ }^{26}$ Международное право. В 2-х книгах : перевод с английского. Кн. 2 / Броунли Я. ; под ред. : Тункин Г. И. ; пер. : Андрианов С. Н. М. : Прогресс, 1977. С. 83.

${ }^{27}$ Brownlie I. The Rule of Law in International Affairs : International Law at the Fiftieth Anniversary of the United Nations. Hague : Martinus Nijhoff Publishers, 1998. P. 83. 
At the same time, it is necessary to ascertain the existence of politically legal problems in the application of attribution rules, which provokes heated discussions in the theory and practice of international law. The reasons for such disputes, as seen, can include: the absence of general mandatory rules, which define the conditions for attribution; the dependence of the application of one or the other rule on the particular circumstances of the case; the contestation of applicable rules and different interpretations in case law and legal doctrine.

\section{The concept "attribution" through the prism of state-oriented and individually-oriented approaches}

For the purpose of deep analysis and evaluation of such a legal phenomenon as "attribution" in international law, in our opinion, two main approaches can be applied: state-oriented and individually-oriented.

These approaches are determined by such two fundamental criteria as the status of the subject of the act that contradicts the international legal obligations of the State and the relationship of the subject of the act that contravenes the international legal obligations of the State with the latter.

The criterion of the status of the subject of unlawful conduct is based on the recognition of the legal significance of the actions of state or non-state actors in establishing the State's international legal responsibility in situations which are determined by international law. In this context it is necessary to distinguish between categories of state and non-state actors whose unlawful conduct is attributed to the State in order to hold them accountable internationally.

For the purposes of attribution state actors should be understood as persons and entities which regardless of their functions and position in the system of the state are part of the state apparatus, exercise state power, in accordance with internal law, state legal practice and the provisions of the law of international relations have the "governmental" status, act in an official capacity, including the ultra vires conduct and violating the rules governing their activities and whose conduct is contrary to the international obligations of the State.

Non-state actors for attribution purposes should be understood as:

1) persons and entities that do not have the governmental status but in certain circumstances perform certain elements of state power, have a functional or factual connection with the State, and whose conduct is contrary to the international obligations of the State;

2) non-governmental individuals and entities acting in the absence of significant for the purposes of attribution functional or actual communication 
with public officials, and whose conduct is contrary to the international obligations of the State (private actors).

The criterion of connection of the subject of the act, which contradicts the international legal obligations of the State with the State itself, is based on the recognition of the legal significance of the functional or actual influence of the state on the subject, the behavior of which is attributed to the State in establishing its international legal responsibility in situations determined by the international law.

According to a state-oriented approach, unlawful conduct can be attributed to the State when it comes from one of its bodies or officials, that is, from one of the elements by which the State functions. In this case, the place of the body or official in the mechanism of the State does not matter: according to Art. 4 the Articles of 2001, the conduct of any State organ shall be considered an act of that State under international law, whether the organ exercises legislative, executive, judicial or any other functions, whatever position it holds in the organization of the State, and whatever its character as an organ of the central Government or of a territorial unit of the State. In this case, the relationship between the State and the subject of the specific conduct is functional.

In addition, under the influence of international practice, special rules for attribution to the State of unlawful conduct committed by a person or entity, which is not state in a narrow sense (stricto sensu) but which have a functional or factual connection with the State, have been developed. Such rules are reflected in Art. 5-11 of Articles on Responsibility of States for Internationally Wrongful Acts of 2001.

These provisions, however, do not take into account the situation of the conduct of persons in the situation of absence of significant in terms of international responsibility connection with the state functions holders. In today's context, it is possible to trace the emergence of a large number of private actors in the international arena, who "undermine" the state-oriented model of international relations, which testifies to the change and transformation of international public law at the beginning of the XXI century, in particular regarding the system of actors, and allows us to single out an individual-oriented approach in addressing the issue of attribution to the State of the conduct of individuals and the imputation of international responsibility on the State. The isolation of this approach is conditioned by the importance of the conduct of individuals in determining the international responsibility of the State.

An individual-oriented approach in the context of the issue of attribution of conduct to the State in order of international responsibility should be considered in two ways: 
1) unlawful conduct of private actors may be attributed to the State for the purpose of determining its international legal responsibility in situations where such actors are not functionally or actualy linked to the State in cases expressly provided by the international law;

2) Due to the unlawful conduct of private actors, which are functionally or actually unrelated to the State apparatus, the conduct of State bodies for failing to comply with the due diligence standard is attributed to the State.

Based on a state-oriented and individual-oriented approach attribution rules can be classified into five main groups:

1) attribution of the conduct of bodies and persons having the status of an authority of a state or its official and acting in such a capacity, including the ultra vires conduct or committed with excess of authority; cases of attribution to the State of the conduct of bodies placed at the disposal of a State by another State;

2) attribution of the conduct of non-state bodies, which nevertheless are authorized to execute the elements of state power and attribution to the State of the conduct of non-state persons and entities that execute the elements of state power in situations of absence or failure of official power;

3) attribution to the State of conduct directed, controlled or supervised by the State; attribution to the State of the unlawful conduct of insurgent or other movements that are successful; an attribution of conduct that is recognized and accepted by the State as its own ex post facto;

4) attribution to the State of unlawful conduct of individuals and entities in situations where there is no functional or actual connection of such actors with the State;

5) attribution to the State in connection with the unlawful conduct of private actors in the conduct of public authorities for failure to comply with the due diligence standard.

Based on the above, we can conclude that "attribution" should be understood as the recognition of the act or omission of state or non-state actors by the State's action in order to determine its international responsibility for the violation of its international legal obligations.

It should be noted that the purpose of attribution is to indicate for liability purposes that it is related to the actions of the State. Attribution of conduct to the State by itself says nothing about the lawfulness or wrongfulness of such conduct and attribution rules should not be formulated in such a way that they have the opposite meaning ${ }^{28}$.

\footnotetext{
${ }^{28}$ Commentaries to the draft articles on Responsibility of States for internationally wrongful acts adopted by the International Law Commission at its fifty-third session (2001). Report of the Commission to the General Assembly on the work of its fifty-third session // Yearbook of the International Law Commission. 2001. Vol. II, Part Two. P. 39.
} 


\section{CONCLUSIONS}

The question of guilt in international law gives rise to different judgments and has no clear answer. Two main directions should be clearly distinguished, reflecting the attitude of the doctrine to the problem of guilt: the position on the recognition of the value of guilt (advocated by Soviet and most post-Soviet international lawyers, as well as some Western scientists); the position of leveling any value of guilt for the onset of responsibility (a significant number of leading scientists in international law).

The following main approaches to the essence of State guilt in international law can be distinguished: the theory of fault responsibility, the theory of objective responsibility, the approach to guilt understanding through violation of due diligence, an eclectic approach to the question of guilt. These theories should be the subject of some thorough research.

The attribution provision occupies a prominent place in international law, which is explained by the need to determine whether a particular act of a state or non-state actor is committed by a State for further bringing it to international responsibility. At the same time, it is necessary to ascertain the existence of political and legal problems in the application of norms on attribution, which causes heated debate in the theory and practice of international law. Among the reasons for such disputes are the following: the absence of general mandatory rules, which define the conditions for attribution; the dependence of the application of one or the other rule on the particular circumstances of the case; the contestation of applicable rules and different interpretations in case law and legal doctrine.

International legal relations, constantly becoming more complicated, determine in today's conditions the growing need for a clear formulation and specification of the rules governing the recognition of State conduct as contrary to the international legal obligations of the State and the adoption of a universal convention on the responsibility of states for internationally wrongful acts. Intense activity in the international arena of non-state actors, including private actors, which violates internationally recognized values and destabilizes the international system, indicates a departure from the traditional state-centered world and requires an adequate response from the international community to new challenges. A deep and comprehensive study of the peculiarities of attribution to the State of unlawful actions by state and non-state actors, including private entities, is absolutely necessary for improvement of the mechanism of international responsibility and increase of the effectiveness of international law. 


\section{SUMMARY}

The question of guilt in international law gives rise to different judgments and has no clear answer. Two main directions should be clearly distinguished, reflecting the attitude of the doctrine to the problem of guilt: the position on the recognition of the value of guilt (advocated by Soviet and most postSoviet international lawyers, as well as some Western scientists); the position of leveling any value of guilt for the onset of responsibility (a significant number of leading scientists in international law). The following main approaches to the essence of State guilt in international law can be distinguished: the theory of fault responsibility, the theory of objective responsibility, the approach to guilt understanding through violation of due diligence, an eclectic approach to the question of guilt. It is determined that "attribution" should be understood as the recognition of the act or omission of state or non-state actors by the State's action in order to determine its international responsibility for the violation of its international legal obligations.

\section{REFERENCES}

1. Brownlie I. The Rule of Law in International Affairs : International Law at the Fiftieth Anniversary of the United Nations. Hague : Martinus Nijhoff Publishers, 1998.

2. Commentaries to the draft articles on Responsibility of States for internationally wrongful acts adopted by the International Law Commission at its fifty-third session (2001). Report of the Commission to the General Assembly on the work of its fifty-third session // Yearbook of the International Law Commission. 2001. Vol. II, Part Two.

3. Convention (IV) respecting the Laws and Customs of War on Land and its annex : Regulations concerning the Laws and Customs of War on Land (1907) URL: http://avalon.law.yale.edu/20th_century/hague04.asp.

4. Convention for the Unification of Certain Rules Relating to International Carriage by Air (1929) URL: http://www.jus.uio.no/lm/ air.carriage.warsaw.convention.1929/doc.html.

5. Convention on the Prevention and Punishment of the Crime of Genocide (1948) URL: http://www.hrweb.org/legal/genocide.html.

6. Dickson Car Wheel Company (U.S.A.) v. United Mexican States (1931) // Reports of International Arbitral Awards. Vol. IV.

7. Eustathiades C. Th. Les sujets du droit international et la responsabilité internationale : Nouvelles tendances / C. Th. Eustathiades / Recueil des Cours de l'Académie de droit international. T. 84. 1953-III. Leyden, Sijthoff, 1955. 
8. Gattini A. Smoking / No Smoking : Some Remarks on the Current Place of Fault in the ILC Draft Articles on State Responsibility. European Journal of International Law. 1999. Vol. 10.

9. Gustav F. W. Hamester GmbH \& Co KG v. Republic of Ghana. ICSID. Case № ARB/07/24. Award. 18 June 2010. URL: http://www.italaw.com/ documents/Hamesterv.GhanaAward.pdf.

10. Kreijen G. State failure, sovereignty and effectiveness : legal lessons from the decolonization of Sub-Saharan Africa. Leiden; Boston : M. Nijhoff, 2004.

11. Marinoni M. La responsabilita degli Stati per gli atti dei low rappresentanti secondo il diritto internazionale / M. Marinoni. Rome, Arthenaeum, 1913.

12. Report of the International Law Commission on the work of its twentyfifth session, 7 May - 13 July 1973. UN Doc. A/9010/Rev.1 Official Records of the General Assembly. Twenty-eighth session. Supplement № 10 // Extract from the Yearbook of the International Law Commission. 1973. Vol. II.

13. Second report on State responsibility by Roberto Ago, Special Rapporteur. The origin international responsibility A/CN.4/233 // Extract from the Yearbook of the International Law Commission. 1970. Vol. II.

14. Settlers in Poland. Advisory Opinion of 10 September 1923 // PCIJ Series B. № 6. URL: http://www.icj-cij.org/pcij/serie_B/B_06/Colons_ allemands_en_Pologne_Avis_consultatif.pdf.

15. Strupp K. Das volkerrechtliche Delikt. Handbuch des Volkerrechts. Stuttgart, Verlag von K. Kohlhammer, 1920. Bd. III, 1st abt.

16. Third Report on State responsibility, by Mr. Roberto Ago, Special Rapporteur, the internationally wrongful act of the State, source of international responsibility. A/CN.4/246 and Add.1-3 // Yearbook of the International Law Commission. 1971. Vol. II, Part One.

17. Анцилотти Д. Курс международного права : введение - общая часть ; пер. с итал. ; под ред. : Д. Б. Левин (Предисл.) ; пер. : А. Л. Сакетти, Э. М. Фабриков. М. : Иностр. лит., 1961. Т. 1.

18. Вадаплас В. Д. Развитие института международно-правовой ответственности // Международное право в современном мире : сб. ст. / отв. ред. Ю. М. Колосов. М. : Международные отношения, 1991.

19. Василенко В. А. Ответственность государства за международные правонарушения. Киев : Вища школа, 1976.

20. Alabama claims of the United States of America against Great Britain (1871) // Reports of International Arbitral Awards. Vol. XXIX.

21. United States v. Great Britain (Home Missionary Society Case) (1920) // Reports of International Arbitral Awards. Vol. VI. 
22. Award between the United States and the United Kingdom relating to the rights of jurisdiction of United States in the Bering's sea and the preservation of fur seals (1893) // Reports of International Arbitral Awards. Vol. XXVIII.

23. Casablanca Arbitration (France v. Germany) (1909) // The American Journal of International Law. Jul., 1909. Vol. 3. № 3.

24. Award in the Matter of the Cadenhead Case (1914) // The American Journal of International Law. Jul., 1914. Vol. 8. № 3.

25. Chattin B. E. (United States) v. United Mexican (1927) // Reports of International Arbitral Awards. Vol. IV.

26. Loizidou v. Turkey. ECHR Judgment of 18 December 1996 // EHRR. Vol. 23.

27. Елынычев В. Н. Вина в международном праве. Советское государство и право. 1972. № 3.

28. Елынычев В. Н. Проблема вменения в международном праве. Правоведение. 1970. № 5.

29. Зелинская Н. А. Международные преступления и международная преступность : [монография]. Одесса : Юридическая литература, 2006.

30.Левин Д. Б. Ответственность государств в современном международном праве. М. : Междунар. отношения, 1966.

31. Международное право. В 2-х книгах : перевод с английского. Кн. 2 / Броунли Я. ; под ред. : Тункин Г. И. ; пер. : Андрианов С. Н. М. : Прогресс, 1977.

32. Міжнародне право : [підручник] / Ліпкан В. А., Антипенко В. Ф., Акулов С. О. та ін. / заг. ред. В. А. Ліпкана. К. : КНТ, 2009.

33. Second report on State responsibility by Roberto Ago, Special Rapporteur. The origin international responsibility A/CN.4/233 // Extract from the Yearbook of the International Law Commission. 1970. Vol. II.

Information about the author: Andreichenko S. S.,

Doctor of Sciences in Law, Associate Professor, Professor at the Department of International Law and Comparative law, International Humanitarian University 33, Fontanska Road str., Odessa, 65009, Ukraine 


\section{PROBLEMS OF LEGAL REGULATION OF THE STATE SERVICE OF UKRAINE}

\section{Chebotareva G. V.}

\section{INTRODUCTION}

The state service of Ukraine, which ensures the legality of political decisions, the integrity of the state as an institution, the qualitative level of implementation of constitutional guarantees of citizens through stable and continuous provision of public services, has a special role in the construction of a modern European-style legal state, the approval of a democratic model of public administration. Therefore, the problem of creating an effective system of public service is of special importance today.

The essential paradigm of modern public service (to provide and/or provide modern, high-quality legislative and regulatory services to legal entities and individuals, as well as other professional activities of civil servants in the practical implementation of the tasks and functions of the state; focus on the final result of the activity, not the process; rational organization of the activities of public authorities; increasing the level of profitability of public services; the effectiveness of the functioning of the public service), the state and problems of the current system, the functions and tasks of the public service determine the importance of reforming this public institution, bringing it into line with European standards. These issues are reflected in documentary, scientific and journalistic literature.

\section{The main directions of reforming the Civil service at the present stage}

Public service is an important institution of the modern state. Public service as an independent type of state professional activity emerged in the second half of the XVII century in Europe, in particular in Germany and France. Until today, the institution of public service has evolved into one of the foundations of a democratic legal state, an important guarantee of the effective functioning of the state mechanism. Although there are different variants of public service systems in the world, it is still possible to name the General features (principles) of public service. This is primarily professionalism, apolitical (political neutrality or loyalty), stability (or indefinite) and public funding ${ }^{1}$.

\footnotetext{
${ }^{1}$ Tsurkan M. legal regulation of public service in Ukraine. Features of litigation disputes: monograph. Kharkiv: Pravo, 2010. 216 p.
} 
As you know, in Soviet times, the domestic science of administrative law did not pay due attention to the development of the theory of public service, which subsequently affected the level of scientific support of the process of formation of this institution in Ukraine.

Creation and current state of the Institute of public service in Ukraine. Recall that the Institute of public service in our country was established only after the Declaration of independence. The current Law of Ukraine "on public service" was adopted for the first time in the territory of the former Soviet Union on December 16, 1993 among the fundamental laws of independent Ukraine, which directly concerned the process of development of statehood, the definition of the basic principles of organization and functioning of public authorities. The main provisions of this Law were developed under the influence of the socio-political situation of the then Ukraine, and therefore its main task was actually to create the institution of public service, since Ukraine inherited from the Soviet era the party-nomenclature organization of public service relations.

The adoption of a separate law on public service made it possible to state the fact of the establishment of the Institute of public service in Ukraine. The law established a system of civil service and civil servants ' career, especially a public office, detailed the concept of foster care services, service career, the system of management of the civil service - a special body of management of state service of the Main Directorate of state service under the Cabinet of Ministers of Ukraine (later, Ukraine) and interagency Advisory body - the Coordination Council on state service.

This gives grounds to believe that the current Law "on public service" has largely fulfilled its task of creating and legislative support for the main directions of functioning of the Institute of public service in Ukraine ${ }^{2}$.

However, in the broader context, the implementation of this Law has not produced the expected results. In today's conditions, the civil service has not yet become a democratic and effective organization of public service activities under the control of society, aimed at solving urgent problems facing society and the state.

Therefore, one of the priority areas of administrative reform in Ukraine, along with structural and functional reforms in the sphere of Executive power, is also the reform of public-service relations. The main goals and objectives of the civil service should be the protection of the constitutional order, the protection of human and civil rights and freedoms, ensuring the effective

\footnotetext{
${ }^{2}$ Kravchenko S. state-management reforms: theoretical and methodological justification and directions of implementation: monograph. Kyiv: NAGU, 2008. 296c.
} 
activities of state bodies in accordance with their powers, providing quality administrative (management) services to citizens.

New approaches to the organization of civil servants activities should be approved. It is necessary to establish standards of quality of work of public servants and their behavior in relations with citizens. Today, the main task of civil servants should be to ensure human rights and legitimate interests. It is necessary to develop a new management ideology aimed at updating the administrative culture, forming the readiness of management personnel to make decisions and increase personal responsibility with a focus on serving the interests of society ${ }^{3}$.

The concept of administrative reform in Ukraine provides that the public service should be based on such principles:

- classification of state bodies and positions of civil servants;

- determination of the scope of public service and the status of civil servants;

- competitiveness, objectivity, transparency and publicity in public service and career;

- improving the administrative culture of civil servants and strengthening public confidence in them;

- legal protection and political neutrality in the public service;

- motivating, stimulating and encouraging public servants;

- professional training for the civil service;

- optimization of the public service management structure.

It is necessary to provide for the fullest possible regulation of various types of public service, among which many researchers distinguish: militarized (armed forces) and civil, which has two subspecies: a) civil service in public authorities (that is, what is called public service under the current Law); b) civil service in institutions and organizations (in educational institutions, health care and other budgetary organizations).

It would be best to adopt a generalizing law on public service, which would serve as a methodological Foundation for the legal regulation of public service, and not on its separate form, but for today's "weakness" of the budget, this seems premature.

Therefore, the scope of regulation of the new version of the law on public service should be specified to the public-service relations related to the functioning of public authorities. The main title of the law regulating the issues of public service in its narrow sense can be "on service in public authorities".

\footnotetext{
${ }^{3}$ Kolpakov V. Administrative law of Ukraine: Textbook, third edition, augmented. Kiev, Yurinkom Inter, 2001. 752 p.
} 


\section{Types of public service}

The activities of the state, the functioning of its administrative apparatus are carried out through the civil service, which is a special institution of the modern state. The institution of public service makes the mechanism of the state capable of practically solving any issues in the field of public administration.

The word "service" itself is used in various meanings. Under the service is understood and the type of activity of people, and departmental unit (state security service of the Ministry of internal Affairs), and an independent Agency (State customs service). Considering public service as one of types of paid socially useful activity the legislator, in Art. 1 of the Law of Ukraine "About public service", gives its definition as professional activity of the persons holding positions in public bodies and their office on practical performance of tasks and functions of the state and receiving a salary at the expense of public funds. These persons are civil servants and have the corresponding official powers. Doctrinally, civil servants are often also referred to as employees engaged in social services. Thus, taking into account the currently legalized definition of public service, it is necessary to distinguish between state bodies (in which, mainly, civil servants serve) and state enterprises and institutions, the work in which is not a public service ${ }^{4}$.

Public service is classified into the following types:

a) service in the legislative, Executive and judicial branches;

b) on civil and militarized (paramilitary) service;

c) PA civil and specialized service;

d) on the state (in state bodies and military) and civil (municipal service, service in the state organizations and establishments.

\section{The problems of classification}

The current legislation of Ukraine on public service does not provide for a clear division of public service into types and types. The law of Ukraine "on civil service" (hereinafter - the current Law) applies only to those civil servants who: firstly, serve in the Executive authorities or in the offices of these and other state bodies; secondly, who are assigned the rank of civil servant. That is, the current Law provides for the so-called narrow interpretation of public service.

In a broad sense, civil servants should be considered all persons who: first, work or serve in state bodies or in the apparatus of such bodies; secondly, who are assigned either the rank of a civil servant, or class ranks or military or special ranks; thirdly, who are financed by public funds.

\footnotetext{
${ }^{4}$ Constitution of Ukraine: Adopted by the Verkhovna Rada of Ukraine on June 28, 1996. 1996. No. 30. P. 141.
} 
In the context of the need to reform the public service system in Ukraine, the decision on the division of public service into appropriate types and types becomes extremely relevant ${ }^{5}$.

Although a clear legislative consolidation of the various types and types of Ukrainian civil service has not yet occurred, this does not mean that in our country there are no different components of the civil service. First, in addition to the current Law, there are other laws that actually regulate public service issues in various areas (diplomatic service, sanitary and epidemiological service, police service, etc.). Secondly, a significant part of the persons who are not directly covered by the current Law are classified as civil servants. Thirdly, there is an urgent need to unify the current legislation based on the constitutional principle of separation of state power into the relevant branches (legislative, Executive, judicial) and functional components of public administration.

It is proposed to apply the principle of division of the entire civil service into three types. In addition, there are two main types - civil service and militarized service. Those components of the public service that they cannot be attributed to these two types should be grouped into an intermediate (third) type-specialized. This approach will make it possible to classify the whole set of legal relations arising in the public service by type and species characteristics.

Approaches to classification of types of public service. Recall that various researchers proper to do the division of civil service on civil and militarized. For example, D. Bakhrakh notes that the militarized service is characterized by such signs, different from the civil service: the professional duty of employees of this category is to protect the life and health of people, ensuring the safety of citizens and the established order of management, material values, protection of public order and law and order; the right to enter the civil service of a militarized character are persons who reach the age of eighteen years; special disciplinary statutes, regulations about discipline due to the specific characteristics of official powers militarized civil servants; the civil servants have special conditions of entry on duty, the conditions of its passage, the assignment of military and special ranks, attestation and termination of service; have installed in the special administrative-legal regulations of the special legal status of militarized civil servants; special order of attraction to the "legal responsibility".

${ }^{5}$ Code of Ukraine on administrative offences: Enacted by the Supreme Council Of the Ukrainian SSR from 07.12.1984. Bulletin of the Supreme Rada of the Ukrainian SSR. 1984. Annex to No. 51. P. 1122.

${ }^{6}$ Administrative law of Ukraine. Academic course: Textbook: in 2 t./ Vidpovid. ed. Averyanov: Vol. 1: General part. Kyiv: legal opinion, 2007. 591 c. T. 2: special part. Kyiv: Yuridichna Dumka, 2009. 600 s. 
Quite common is the point of view of V. Averyanov, who proposed legislation to delimit such types of public service:

1) service in organs: viscounts power and apparatus, and also in apparatus Parliament, judicial organs, other public bodies (for example, prosecutors). This is actually an administrative service, or the service of officials;

2) service in state bodies (including some bodies of Executive power), which receives a special legal status, including in the Prosecutor's office, internal Affairs, state security, customs authorities, diplomatic institutions, the armed forces. It is a specialized service;

3) service in various state bodies and their apparatus, which, although it has a support and service orientation, but because of its importance requires a special legal regime within the public service. This is the functioning of the so-called patronage services (conditional patronage service).

Moreover, the author believes that "before the institution of public service should not include the activities of persons who, although they perform the most important state-power functions, but have the status of "political figures" and not "civil servants". These persons include the President of Ukraine, the Prime Minister of Ukraine, members of the government of Ukraine, heads of local state administrations, people's deputies of Ukraine, elected officials of the Parliament, including the Chairman of the Verkhovna Rada of Ukraine. The legal status of these persons should be regulated in detail in separate legislative acts" ${ }^{\prime 7}$.

\section{Problems of legal regulation of behavior and disciplinary responsibility of civil servants}

Implementation of large-scale administrative reform in Ukraine, including improvement of the civil service system, will not give the desired positive result if new approaches to the legal regulation of the behavior of civil servants are not introduced.

The need for legislative regulation of the behavior of civil servants. In the current Law of Ukraine "on civil service" (hereinafter - the current Law), a separate article is devoted to the behavior of civil servants: "Article 5. Ethics of conduct of a public servant", according to which a public servant must:

- conscientiously to forge official duties;

- respect citizens, managers and employees, adhere to a high culture of communication;

- to prevent actions and actions that may harm the interests of the public service or adversely affect the reputation of the public servant.

\footnotetext{
${ }^{7}$ About measures for introduction of the concept of administrative, reform in Ukraine: the Decree of the President of Ukraine No. 810 of 22.07.1998. Official journal of Ukraine. 1999. No. 21. P. 943.
} 
It is clear that the tightening of requirements to the behavior of civil servants should be carried out simultaneously both by the state - by means of law and by society - by means of morality. Therefore, the successful solution of these problems is possible by establishing certain, accurate, understandable and, most importantly, acceptable to modern Ukrainian society moral and ethical requirements for permissible manifestations of behavior of civil servants and their legislative consolidation. The complexity of the practical implementation of this task lies primarily in the identification of those rules of conduct of civil servants that are generally recognized, as well as in solving the problem of the ratio of legal norms and moral and ethical requirements.

Now requirements to behavior exist, but they are scattered on different, mainly by-laws, acts. It seems that it is necessary to focus all the requirements for the behavior of civil servants in one legal act of a codified type ${ }^{8}$.

It will allow, first, to group requirements in concrete norms in interrelation and depending on degree of their public danger; secondly, to establish a certain ratio between moral responsibility and responsibility legal for violation of rules of behavior; thirdly, to improve legal responsibility for violation or non-performance of rules of behavior by civil servants by legislative establishment as General requirements (for all community of officials), and special requirements (for special category of civil servants - officials).

Basic requirements for the behavior of civil servants. We should not forget that it is important to determine what requirements for the behavior of employees should be considered basic. The main are considered such:

- respect for the rule of law in the second activity;

- observance of the moral and ethical requirements of behavior accepted in society;

- prevention of corruption;

- conscientious and professional performance of official duties;

- preservation of state and other secrets protected by law.

Ethical requirements for employees in General and civil servants in particular at different times and in different countries were both fundamentally similar and diametrically opposite. Now in Ukraine the ethical requirements to conduct of civil servant is mainly perceived as an important form of professional ethics, which are a set of moral rules of conduct of civil servants, with which to assess its activities in terms of such values as justice, honesty, conscience, dignity, humanity, compassion, responsibility, professionalism, patriotism and the like.

${ }^{8}$ Code of Ukraine on administrative offences: Enacted by the Supreme Council of the Ukrainian SSR from 07.12.1984. Bulletin of the Supreme Rada of the Ukrainian SSR. 1984. Annex to No. 51. P. 1122. 
In principle, the issue of political loyalty of employees to the political leadership needs to be addressed. Here it is not a question of interference in personal life or restriction by certain limits of Outlook of the employee as the person or the citizen ${ }^{9}$.

A civil servant shall not use his official position to obtain additional income, benefits or other benefits from any legal entities and individuals, both for himself, relatives and friends, and for other persons, and shall not violate restrictions and prohibitions against civil servants established by the anticorruption legislation and the Law of Ukraine "on civil service".

Civil servants are constantly working with a lot of information. Therefore, the behavior of a civil servant to preserve state and other secrets protected by law is one of the most important objects of regulation. As a rule, a state employee is prohibited from disclosing state secrets entrusted to him in connection with the performance of official powers, other information with limited access, including after leaving the state service. This question is quite controversial, but its very formulation, in our opinion, is correct. Therefore, we propose to set a period for non-disclosure of state or other legally protected secrets in accordance with the Law of Ukraine "on state secrets" and "on information", and for non - disclosure of confidential and private information-five years after retirement from public service.

In The code of conduct it should also be noted that the employee as a General rule should not use the information obtained in the course of the performance of official duties, the disclosure of which is prohibited both in their own interests and in the interests of other persons, except for cases when such use is aimed at preventing a real threat to life or health of people ${ }^{10}$.

\section{Problems of systematization of legislation on public service}

The civil service is a multi-element legal institution. Most of the legal norms regulating it are now concentrated in administrative law. The legislation of Ukraine on civil service is considered a sub-branch of administrative legislation.

The systematization of administrative legislation, part of which is the legislation on public service, is an extremely urgent problem now. Systematization of this legislation is quite a difficult task. This is explained to some extent by the fact that, first, it is now the law consists of the basic legislative act - the law of Ukraine "On civil service" of 1993 (hereinafter the

\footnotetext{
${ }^{9}$ On the Cabinet of Ministers of Ukraine: Law of 07.10.2010. Sheets of the Verkhovna Rada of Ukraine from 04.03.2011. No. 9, page 429, article 58/

${ }^{10}$ About public service: the Law of Ukraine of 10.12.2015. Sheets Of The Verkhovna Rada. 2016. No. 4. P. 43.
} 
current Law), as well as from a large number of regulations - more than twenty decrees of the President of Ukraine and over a hundred resolutions of the Cabinet of Ministers of Ukraine (hereinafter - regulations); secondly, the full systematization of this legislation in the past period was not carried out.

At the same time, the legislation on public service does not correspond to many norms-regulations of the Constitution of Ukraine, it is obsolete, cumbersome, regulations largely inconsistent and the like. In particular, the still ongoing practice of trying to settle the relations of the public service regulations, despite the fact that the Constitution requires the organization and activities of bodies of Executive power, the fundamentals of state service" was defined exclusively by laws (paragraph 12 of part one of article 92). A serious drawback is the conceptual focus on the regulation of public-service relations arising in connection with and about the passage of public service, mainly by private legal means inherent in labor law, and the diminution of the value of public-legal means inherent in administrative law. There is also a lack of system of the whole array of different legal nature of the acts devoted to public service, which led to the parallel existence of different types of public service, the development of which in conceptual terms, in our opinion, should be based on common principles and approaches. As rightly pointed out in this regard, V. Averyanov, the current Law of Ukraine "on public service" does not systematically solve the conceptual issues of creating an integral Institution of public service in our state ${ }^{11}$.

Systematization of legislation should be carried out by its inherent methods. As is known, systematization is carried out in the form of incorporation and codification. Therefore, it is necessary to determine the priority way to systematize the legislation of Ukraine on public service.

In the course of the forthcoming systematization of legislation on public service, it is necessary to focus on the main thing-the release from outdated acts and the preparation of a new legislative act, the replacement of contradictory norms and constipation in such a new act of progressive legal structures, the elimination of legal gaps by offering modern scientific views and approaches.

To do this, it is necessary to focus on codification. Incorporation should be given a supporting role - to conduct an ongoing review of legal acts for the removal of no longer existing provisions and making appropriate additions.

So, despite the fact that the civil service is a special institution of the modern state, it is necessary to codify the legislation of Ukraine on public service.

${ }^{11}$ On the Central bodies of Executive, power the Law of 17.03.2011. Official Visnik Ukrainy vid 18.04.2011. No. 27, p. 320 , article 1123 
As it is known, the basic codification acts include: fundamentals of legislation-normative legal acts that establish the most important provisions (basic principles) of a certain branch of law or the sphere of state administration; code-the most common type of codification acts acting in the main spheres of public life that require legal order; Charter, regulationscodification acts of special action, which are adopted not only by legislative but also law-making bodies (for example, the government).

In preparation for the systematization, it should be borne in mind that the codification of legislation on public service is a complex problem of legal science. The fact is that various branches of law regulate the institution of public service simultaneously, in particular such as constitutional, administrative, labor, financial, civil, and criminal and the like. At the same time, administrative law exerts the most significant influence on the civil service. It is no coincidence that today the civil service is considered as a subbranch of administrative law.

The process of codification is quite complex and painstaking work, in particular because it involves such three stages as: identification of legislative shortcomings of a particular industry (sub-sector); elimination of such shortcomings by means of law and legal technology; bringing the processed material into a single whole in order to consolidate it at the legislative level.

The basis for the codification of the legislation on public service should already be taken at the highest state level political decisions on the need for state law reform in Ukraine and on the assignment of the basic provisions of the Concept of administrative reform in Ukraine as the basis for the implementation of the reform of the public administration system. This Concept, in particular, provides that, first, it is necessary to revise the legislation in relation to the public service. Along with amendments to the current Law of Ukraine "on public service" and improvement of existing legal acts, "in the future, it is necessary to adopt a generalizing law that would serve as a methodological and regulatory Foundation for the legal support of an integral Institution of public service, taking into account all the features at different stages of its development."

Codification is primarily subject to those institutions of public service that are insufficiently regulated by the current Law, their regulation is carried out not by Law, but by bylaws, or they are still regulated by other branches of law.

Such codification should be aimed at overcoming existing contradictions and inconsistencies in the current legislation, based on modern scientific ideas about the Institute of public service with its inherent features and prospects for improvement. 


\section{CONCLUSIONS}

Since the entire system of public service of Ukraine is subject to reform, we focus only on the main unresolved problems that need to be eliminated as a result of codification.

First, the scope of the institution of public service in Ukraine requires a clear definition. For this purpose, it is necessary, at last, to get rid of terminological uncertainty and as soon as possible legislatively to fix concept "the civil servant", "the state position of public service", and to specify value of the basic term "public service". At the same time, it is necessary to take into account the terminological divergence of the content of the concepts of "work" and "service". This will help to determine the broad and narrow understanding of the concept of "public service" in favor of one of them. In particular, we propose to choose a narrowed approach. That is to consider as civil servants only those persons who professionally and for the state means carry out tasks of public administration and state regulation on positions of public service in public bodies of their office. It should also be borne in mind that the terms "public service", "public sector", "public sector" cannot coincide.

Secondly, it is necessary to move to the legal regulation of public service and legal relations arising in connection with its passage by civil servants of state bodies and their apparatuses, methods of public law inherent in administrative, constitutional and other public branches of law, and at the same time to stop the use of private law methods inherent in civil and labor law. That is, the legal relations of the civil service should be regulated not by labor, but by administrative law.

Scientists have already made various proposals, including those that are quite difficult to agree on the ways and methods of codification of legislation on public service, as well as the form of future codified acts. For Example, V. Would. Averyanov believes that this may be the fundamental Law of Ukraine "on the basics of service in the state", which would include: General provisions inherent in all categories of civil servants; comprehensive classification of civil servants; regulation of the organization of management of the civil service, etc.

\section{SUMMARY}

The main directions of reforming the civil service at the present stage. Types of public service: problems of classification. Problems of legal regulation of behavior and disciplinary responsibility of civil servants. Problems of systematization of legislation on public service. 


\section{REFERENCES}

1. Constitution of Ukraine: Adopted by the Verkhovna Rada of Ukraine on June 28, 1996. 1996. No. 30. P. 141.

2. Code of Ukraine on administrative offences: Enacted by the Supreme Council of the Ukrainian SSR from 07.12.1984. Bulletin of the Supreme Rada of the Ukrainian SSR. 1984. Annex to No. 51. P. 1122.

3. About public service: the Law of Ukraine of 10.12.2015. Sheets Of The Verkhovna Rada. 2016. No. 4. P. 43.

4. On the Cabinet of Ministers of Ukraine: Law of 07.10.2010. Sheets of the Verkhovna Rada of Ukraine from 04.03.2011. No. 9, page 429, article 58.

5. On the Central bodies of Executive power: the Law of 17.03.2011. Official Visnik Ukrainy vid 18.04.2011. No. 27, p. 3 20, article 1123.

6. About local state administrations: the Law of Ukraine of 09.04.1999. Sheets of the Verkhovna Rada of Ukraine of 28.05.1999. No. 20, article 190.

7. About measures for introduction Of the concept of administrative reform in Ukraine: the Decree of the President of Ukraine No. 810 of 22.07.1998. Official journal of Ukraine. 1999. No. 21. P. 943.

8. Administrative law of Ukraine. Academic course: Textbook: in 2 t. / Vidpovid. ed. Averyanov: Vol. 1: General part. Kyiv: legal opinion, 2007. 591 c. T. 2: special part. Kyiv: Yuridichna Dumka, 2009. 600 s.

9. Bityak Y. Civil service in Ukraine: organizational and legal basis. Kharkiv: Pravo, 2005. 304s.

10. Kolpakov V. Administrative law of Ukraine: Textbook, third edition, augmented. Kiev, Yurinkom Inter, 2001. 752 p.

11. Kravchenko S. state-management reforms: theoretical and methodological justification and directions of implementation: monograph. Kyiv: NAGU, 2008. 296c.

12. Tsurkan M. legal regulation of public service in Ukraine. Features of litigation disputes: monograph. Kharkiv: Pravo, 2010. 216 p.

\section{Information about the author:} Chebotareva G. V.,

Doctor of Law, Professor, Professor of the Department of Administrative,

Criminal Law and Procedure, International University of Business and Law 37-A, 49 HGD str., Kherson, 73040, Ukraine 


\title{
PLACE OF ADMINISTRATIVE SUPERVISION IN THE ACTIVITIES OF THE EXECUTIVE POWER OF UKRAINE
}

\author{
Denysova A. V.
}

\section{INTRODUCTION}

The constitutional and legal content of the executive power is a result of the prescriptions of the Constitution of Ukraine, which provides for the separation of state power into legislative, executive and judicial branches. The purpose of separation is to ensure the rights and freedoms of man and citizen, political stability. Separation of state power is the basis of the deconcentration of power, which excludes of excessive concentration of power in individual state bodies, dangerous for the public freedom, ensures "preventing the appropriation of the completeness of state power by one of the branches of power". Separation of state power acts as a principle, the basis of the functioning of the mechanism of the state and is implemented in the activities of the relevant bodies and they are the legislative, the executive and the judiciary, each of which performs separate tasks and functions, but within the sole purpose of the state power, which involves interaction between them. Separation of state power does not preclude interaction between public authorities, including the provision of necessary information, participation in the preparation or consideration of a particular issue, etc. Such interaction should be permermed taken into account the requirements of the Constitution of Ukraine, according to which state authorities are obliged to act on the basis, within the powers and in the manner provided by the Constitution and laws of Ukraine.

This means unity in the content of state power, and the constitutional principle of separation of powers is a theoretical constant, which allows to build a state mechanism and organize its functioning, which means in organizational terms the realization of state power through certain types of state bodies. The powers are distributed among them in such a way that they are independent in exercising their competence within the limits established by the Constitution and interact with each other by means of certain levers of mutual "restraint" and "counterbalance".

Scientists note that not only power is shared, but the functional and structural mechanism of its implementation. In one case, separation of powers means the separation of the main functional activities of the state lawmaking, enforcement and justice, and in the other that the organizational structure of the state as a set of different types of state bodies and they are legislative, executive and judicial (these are only the main types), with their inherent competence which is a set of state-power powers 


\section{The essence of the executive power in Ukraine}

The peculiarity of executive power among the branches of state power is manifested in its focus on the implementation of laws and other normative acts of the state, as well as in the practical application of all levers of state regulation and management of important processes of social development. The decisive focus of the executive is to assert and secure human rights and freedoms and is recognized by the Constitution of Ukraine (Article 3) as "the highest social value" ${ }^{1}$.

The constitutional and legal nature of the separation of state power determines the need to distinguish the following features of the executive power:

- inalienability in the separation of state power;

- is one of the functional activities of the state - law enforcement;

- is a component of the functional and structural mechanism of exercising state power;

- is a component of the organizational structure of the state in the form of a system of bodies of executive power; power ${ }^{2}$.

- organizationally represented by the entities, holders of executive

The constitutional and legal content and organizational form are reproduced in the listed features of the executive branch. This means that the principle of separation of powers as the basis for the functioning of the mechanism of the state is organizationally represented by the system of executive bodies. At the same time, the essence of the executive power in the light of the principle of separation of state power is characterized from the point of view of implementation of one of the functional activities of the state and it is the implementation of laws. The executive nature of power, which determines the content of the executive power, causes the expansion of the executive power and it is beyond the system of executive bodies, which allows to indicate the exercise of executive power by its holders who are authorized entities.

In this connection, scientists point to the need to distinguish between public administration and executive power, noting that some of the functions of public administration are exercised outside the executive power, but at the same time, some of the functions of executive power are exercised outside of public administration. This means that public administration can be carried

\footnotetext{
${ }^{1}$ Виконавча влада і адміністративне право/ За заг.ред. В.Б. Авер'янова. К.: Видавничий Дім “Ін Юре”, 2002. 668 с.

2 Денисова А. В. Сущность и содержание базовых категорий административного права: отдельные проблемы определения / А. В. Денисова // Legea si Viata. - 2017. - № 3/2 (303). C. $57-60$
} 
out not only within the system of executive bodies, but also when organizing the activities of enterprises, institutions, organizations of state ownership. The executive power is also exercised in the case of delegation of powers to the bodies of local self-government. Thus, public administration and executive power are regarded as legal phenomena, and the corresponding categories indicate the peculiarities of their manifestations in the organization of the functioning of the mechanism of the state. These legal phenomena are reproduced in the competence of the entities of the state administration and the executive power. The constitutional and legal content of the executive power determines its legal significance, which is wider in content and essence than the state administration.

The essence of administrative activity is revealed in the research of scientists who dealt mainly with the problems of legal protection and the activity of law enforcement agencies. The term "administrative activity" refers to the imperative, state-governmental, executive-administrative activity of law enforcement agencies, which concerned both management and issues of application of administrative-jurisdictional powers.

It is advisable to mention the scientific approach of Zolotarova N.I., who points to the wider meaning of the notion of administrative activity of the authorities compared to the concept of the executive. The researcher emphasizes the difference in the entities of administrative activity and executive power. Thus, the executive power is exercised only by the bodies of this branch of power and special institutions, and powers to exercise the functions of the bodies of the executive power are delegated to them. The number of entities of administrative activity, which are called administrative by the researcher, and they are regulated by the norms of administrative law, it is wider, because it is carried out not only by executive bodies, but also by courts, prosecutor's offices, the Secretariat of the Verkhovna Rada of Ukraine, and the Presidential Administration. These entities carry out organizational activities related to the performance of administrative functions ${ }^{3}$.

However, Zolotarova N.I. determines the relationship between the administrative activity of the authorities and the executive power, using terms whose content needs clarification and concretization. In particular, the above refers to terms such as "organization", "institution", which leads to some inaccuracies in the definition of the subjective composition of administrative activity and executive power. That is why this approach of the researcher, although it is interesting, is not unquestionable.

3 Золотарьова Н. І. Співвідношення виконавчої влади та адміністративної діяльності / Н. І. Золотарьова // Вісник Національного технічного університету “КПІ". - 2011. № 1 (9). - C. 45-54. 
Another approach is to identify the nature and content of administrative activity that implies its focus on the exercise of citizens' rights and freedoms in the field of governance. Among the features of administrative activity, the executive and administrative nature is indicated, the entities are public authorities, regulated by the rules of administrative law ${ }^{4}$. Revealing the essence of the executive nature of the activity of executive bodies, Melnyk A.F. noted that it is practical implementation of legislative acts, operational and dynamic management of economic and social spheres, as well as statepolitical activity (defense, security, customs and tax). According to the researcher, the administrative character of the state-administrative activity is to issue executive bodies of decrees, orders, orders, instructions, rules and other by-laws, which allows to ensure compliance with the norms and principles of the Constitution of Ukraine, laws, other normative acts and effectively manage the branches of economy and socio-cultural sphere ${ }^{5}$.

The definitions mentioned above and characteristics of administrative activity are presented by researchers in the field of public administration, but their work is appropriate even in the case of their use in scientific developments in administrative law. The theoretical novelty of this approach is to take into account the primacy of the rights and freedoms of citizens in this activity, which allows to determine the main purpose of administrative activity of bodies of executive power the realization of citizens' constitutional rights and protection of their rights and freedoms.

Thus, it is expedient to define administrative activity as regulated by norms of administrative law specific, executive-administrative, subordinate, state-government purposeful activity of the authorized bodies of executive power (officials) in the exercise of the constitutional rights of citizens and protection of their rights and freedoms.

Among the features (signs) of administrative activity it is advisable to emphasize:

- executive and administrative character, which is manifested in the enforcement activities of authorized entities, the peculiarities of which are to establish a legal obligation to act clearly within the limits and on the basis of the rules of the current legislation in order to perform the tasks and functions corresponding to the legal status;

${ }^{4}$ Гробова В. П. Адміністративний аспект державного управління / В. П. Гробова // Актуальные проблемы права: теория и практика. Сборник научных трудов. - 2010. № 18. - С. 298-304.

5 Державне управління : навч. посіб./ [Мельник А. Ф., Оболенський О. Ю., Васіна А. Ю., Гордієнко Л. Ю. та ін..] ; під ред. А. Ф. Мельник. - К. : Знання-Прес, 2003. $343 \mathrm{c}$. 
- subordinate nature of administrative activities, which means its focus on the implementation of the law;

- state-governmental character, which means performing administrative activities on behalf of the state and performing the functions of the state. At the same time, the authorized entities act on behalf of the state and their activities are not individualized;

- accountability and control as characteristic features (features) of administrative activity, the specificity of which is determined, first of all, by the imperative nature of the activity of executive bodies.

In revealing the content of accountability, Sinkova A.M. described it as a legal category, which is considered in the current legislation, primarily from the point of view of the form of management, which is a prerequisite for ensuring socio-political stability and making optimal decisions. The researcher defines accountability as a tool for creating information flows and defining communicative interactions between executive bodies, as well as between the system of executive authorities and the external environment ${ }^{6}$.

Taking into account the scientific approach Synkova O.M. on the essence of accountability allows to distinguish the administrative nature of administrative activities. This approach does not identify management and administrative activities. Being legal phenomena of different order of administration and administrative activity they are correlated as general and special. In this case, management is viewed from the standpoint of the general legal phenomenon, as opposed to administrative activity, which reproduces the specific purposeful nature of management. Along with this approach, it is advisable to talk about the procedural aspect of the relationship between management and administrative activity, according to which administrative activity should be indicated as a component of management activity, taking into account the difference in the entities of implementation. If administrative activities (according to the existing theoretical experience) are connected with executive authorities, then administrative activity is carried out by a wider range of entities.

In the case of a wide approach to defining the nature and content of management and administrative activity, it is appropriate to note their identical nature, especially given the designation of the term "administrative" purposeful influence on a particular object.

Therefore, characterization of the content of management and administrative activity can be implemented in aspects of material and

\footnotetext{
${ }^{6}$ Синкова О.М. Підзвітність в системі органів виконавчої влади: організаційно-правові проблеми: дис. ... д.ю.н. 12.00.07 / Синкова Олена Михайлівна / Інститут держави і права ім. В. М. Корецького НАН України. - К., 2011. - 400 с.
} 
procedural by "wide" or "narrow" approaches. The material aspect involves the characterization of management and administrative activity as legal phenomena. Procedural is a type of activity (a set of sequentially performed deliberate procedures) of authorized entities. The "wide" and "narrow" approaches are a logical extension of the procedural aspect of the nature and content of management and administrative activity.

The consideration of the procedural aspect in the characterization of administrative activity allows to distinguish organizational and jurisdictional types of administrative activity. Organizational refers to the formation of the state apparatus, administrative decisions, the implementation of logistical operations, the performance of office functions, personnel, information support, etc. Jurisdictional administrative activity concerns the application of measures of administrative compulsion, bringing to administrative and disciplinary responsibility, administrative appeal.

According to the directions of influence, administrative activity is divided into internal organizational (internal) and external organizational (external). Internal organization refers to the ordering of relations within the structure of the system of executive bodies: personnel, information, resource and other types of security. External organizational administrative activity is the main activity of executive bodies aimed at fulfilling the tasks and functions assigned to them by the current legislation. Administrative-supervisory activity is a part of the external organizational activity of executive bodies.

At the same time, it is worth to mention about the latest developments on the problem of dissemination of the dispositive method in administrative law. Thus, according to Riabchenko O.P., in the economic sphere, the means and measures inherent in the dispositive method of public-legal regulation of relations should be developed, which means establishing the legal possibility of alternative choices by participants of these relations of behavior within the law. Such legal possibility is realized, in particular, in permits, administrative contracts, administrative services that ensure social freedom and human activity, the implementation of the principle of "what is not prohibited by law" is allowed? .

This approach allows you to extend the nature of administrative activity, introducing the principles of dispositiveness. Mentioned information determines the need to establish such a feature of administrative activity as the legal possibility of applying the dispositive method in order to streamline public-legal relations.

7 Рябченко О. П. Концептуальні проблеми застосування диспозитивного методу публічно-правового регулювання відносин у сфері економіки / О.П. Рябченко: наукова доповідь. - К.: Логос, 2013. - 40 с. 
Taking into account mentioned information, we can distinguish the following features (signs) of administrative activity:

- is executive-administrative;

- is by-law;

- has a state-power character;

- is accountable and controlled;

- has the legal possibility of applying the means and measures of influence inherent in the dispositive method ${ }^{8}$.

The listed features (signs) of administrative activity reflect its executive nature, which allows to speak about its compliance with the executive activity, which is carried out by the executive power bodies, authorized entities.

It should be emphasized that there are no contradictions in establishing the features of administrative (executive) activity of the state-governmental nature and the availability of a legal possibility of applying the principles of dispositiveness, given that the latter feature forms a modern perception of state-governmental activity as such, within which administrative services may be provided, administrative contracts may be concluded.

Thus, in the categories "executive power", "public administration", "administrative activity" are their executive nature and state power. Even if there is a legal possibility of using the means and measures inherent in the dispositive method of legal influence, the authorized person for their application acts for the purpose of performing state tasks and functions and is not individualized. The doctrine of public administration needs to be substantially updated, taking into account the tendencies to modernize the forms and methods of administrative and legal influence characteristic of the dispositive method of public legal regulation: an administrative contract, an administrative service, the need for the development of which is objectively conditioned by the social essence of social transformations. Provided they are taken into account; one can anticipate the convergence of the doctrine of public administration into public administration. The modern approach to defining the essence of the category "public administration" allows to speak about its narrower meaning in comparison with the categories "executive power" and "administrative activity".

The search for a single category, which should take into account theoretical principles, on the one hand, and the executive nature of the activities of authorized entities, has recently led to the active use of the term "public administration" in scientific research.

8 Денисова А. В. Сутність адміністративної діяльності щодо здійснення нагляду органами виконавчої влади та їі місце у виконавчій владі / А. В. Денисова // Актуальні проблеми держави і права. - 2017. - Випуск 79. - № 79. - С. 46-50. 
According to scientists, public administration reveals the main directions of purposeful activity of entities of power over the performance of administrative duties ${ }^{9}$. In essence, this approach can be called wide, taking into account the fact that it covers all the activities of entities vested with powers that carry out administrative content obligations. However, taking into account the substantive ambiguity (that is, the lack of a unified scientific approach to determine the essence) of the term "entity of authority", that was repeatedly noted by scholars who analyzed the problems of judicial administrative jurisdiction and ambiguity of meaningful content in the category administration is inappropriate.

The scientific approach of Vitvitskyi S.S. is interesting, the scientist proposed to systematize the activities of public administration and distinguish three types of it: 1) managerial (organizational, as well as public service); 2) control; 3) administrative and jurisdictional. The researcher, relying on scientific approach Tymoshenko K.O., stated that administrative-judicial activity can be considered from the standpoint of guarantees of legality and restoration of the violated right, which is carried out by authorized entities public administration and courts (administrative courts) ${ }^{10}$.

This approach can be accepted in case that the public administration (whose activity is called public administration) is performed by the state executive bodies, local self-government bodies in the exercise of the delegated powers of the executive power. Right this approach to the definition of public administration is suggested by Vitvitskyi S.S. At the same time, supervision is not singled out as a separate activity of public administration.

Approach presented by Vitvitskyi S.S. can be applied to determine the place of administrative oversight among public administration activities (ie, public administration). Considering the nature of administrative oversight does not allow it to be attributed to control or administrative and jurisdictional activity, especially considering the fact that supervision combines both positive and negative (extrajudicial) administrative activities. Taking into account mentioned information, it is appropriate to note that the administrative oversight carried out by the executive authorities is covered by the control and administrative-jurisdictional activities of the public administration. The term "public administration" means the bodies of state executive power and local self-government bodies in the part of exercising their delegated powers of executive power.

${ }^{9}$ Курс адміністративного права України: підручник / В. К. Колпаков, О. В. Кузьменко, І. Д. Пастух, В. Д. Сущенко [та ін.] / за ред. В. В. Коваленка. - К.: Юрінком Інтер, 2012. $808 \mathrm{c}$.

${ }^{10}$ Вітвіцький С. С. Контроль діяльності публічної адміністрації в Україні: теорія і практика [монографія] / С. С. Вітвіцький. - Дніпропетровськ: Дніпропетровський державний університет внутрішніх справ, 2015. - 362 с. 
The approach of introducing the term "public administration" presented by the researchers is not well established and needs further scientific analysis. Thus, according to the meaning of the word "public", the term "public administration" should cover not only the activity of executive bodies, but also the activity of all public authorities, local self-government bodies, public and international organizations.

Appeal to legal encyclopedic publications gives the opportunity to distinguish the legal meaning of the term "public", which follows from the content of the terms "public law", "public-legal relations", "public interest".

Public law is the system of legal rules governing relations in the sphere of public authority. The entity of regulation of public law is the structure and functioning of the state, its institutions, institutions of civil society, human and civil rights and freedoms, the relationship between the individual and the state in the field of public order, the mechanism and levels of self-government, consolidation of public interest in the system of finance and labor, the basics of the legal system, lawmaking and enforcement, principles, norms and institutions of interstate relations and international organizations. Regarding public-law relations, it is stated that such are public relations that arise between certain entities of law mainly concerning the exercise of publicpower powers, realization and protection of subjective public rights and freedoms, satisfaction of public interests and regulated by a complex of public-legal norms of different branches of law ${ }^{11}$. In the theory of law, public law is defined as a subsystem of law, which consists of norms governing relations related to the exercise of functions of public authority in the sphere of the interests of the state and local self-government through the imperative method of legal regulation. Public interest is the general public interest recognized by the state, which relies on its support and legal protection ${ }^{12}$.

Therefore, the legal meaning of the category "public" is revealed in legal phenomena that do not involve individualization and do not relate to private (personal) interest. According to the modern content of public administration, this category is close to the content of the category "public administration". Against this background, the content of the terminology of the term "public administration" needs further scientific analysis and clarification.

The following requirements for scientific terms should be taken into account when conducting further research to clarify the term "public administration":

11 Великий енциклопедичний юридичний словник/ За ред.. акад.. НАН України Ю. С. Шемшученка. - 2-ге вид., переробл. і доповн. - К.: Вид-во "Юридична думка", 2012. $-1020 \mathrm{c}$.

12 Теорія держави i права: підручник/ О. В. Петришин, С. П. Погребняк, В. С. Смородинський та ін.; за ред. О. В. Петришина. - Х.: Право, 2015. - 368 с. 
- should denote concepts that are the result of direct knowledge of state and legal reality;

- should reflect social realities;

- their appearance, change or removal from circulation should be dictated by the real needs of the practice;

- the legislation should stipulate those scientific terms that are conventional in nature, they are called doctrinal terms ${ }^{13}$.

If you apply the above requirements to the term "public administration", then there are at least two questions. First, the introduction of a new term requires a well-grounded critique of pre-existing terminology. Secondly, it is necessary to prove the objective nature of the need to introduce a new term in the presence of existing and elaborated in the doctrine of administrative law.

Next after the logic of scientific analysis is the question of the relationship between the terms "public administration" and "state regulation", for analysis of which an approach was proposed, which involves the use of the general concept of "organization" (or "organizational activity"). In this case, the concept of "organization" is not limited to considering it as "organizational activity", but also considered as the organization of a system of authorities that exercise their authority to achieve specific goals in certain areas of public administration and regulation. Revealing the relation between these concepts in the example of tourism industry management, the wider meaning of the term "regulation" is defined. Thus, the state administration covers the type of activity of the state, the content of which is to exert organizational influence on a certain branch (in fact - the entity of public administration) by using the powers of executive authorities and local self-government bodies through the implementation of laws, implementation of administrative functions, ensuring the implementation of public policy. State regulation is a set of methods of public administration, which provides for a system of measures of legislative, executive and control nature and is carried out by state bodies in a certain area in order to stabilize its functioning ${ }^{14}$.

In this approach, administrative oversight goes beyond public administration and state regulation, given that this type of state activity also applies to the exercise of jurisdiction by authorized entities. Therefore, the term "administrative activity" is more consistent with the nature and content of administrative oversight.

13 Любченко М. І. Юридична термінологія: поняття, особливості, види: монографія / М. І. Любченко. - Х.: ТОВ “Видавництво права людини”, 2015. - 280 с.

14 Чан Тхуи Ван. Организационно-правовое обеспечение туризма во Вьетнаме (сравнительный анализ с Украиной): дис.к.ю.н. 12.00.07/ Чан Тхуи Ван/ Инстиут государства и права им. В. М. Корецкого НАН Украины. - К., 2016. - 206 с. 


\section{Place of administrative supervision in the executive branch}

Determining the place of administrative oversight in the executive branch, it is expedient to highlight the approach of Salishcheva N.G. regarding the essence of state-power powers, which are considered in the context of federal executive bodies. Thus, state-governmental powers of federal executive bodies are proposed to be considered as:

- the legislative powers that enable the relevant body (government, ministry) to establish certain rules, as well as standards, normative requirements, prohibitions, administrative regimes, etc.;

- enforcement powers, that is, the right to carry out certain legal actions, to adopt normative legal acts, to resolve specific conflicts between entities of administrative activity, to carry out permitting functions, to provide administrative (state) services;

- law enforcement powers, ie the right to ensure legality and discipline, to carry out administrative and jurisdictional activities, to apply measures of administrative coercion, administrative responsibility ${ }^{15}$.

Approach of Salischevoyi N.G. may be taken into consideration with certain reservations. Thus, the scientist emphasizes the law enforcement nature of the powers of the executive authorities, which, although it is acceptable for determining the nature of state-power powers, nevertheless reflects one aspect of the functioning of the executive authorities.

Academician Averianov V.B. singled out the activities of bodies that are not administrative in essence: applying to the citizens measures of administrative coercion, including administrative penalties; extrajudicial protection of violated rights and freedoms of citizens (in order of administrative appeal); consideration and resolution of administrative cases at the request of individuals, including the provision of various administrative (management) services in the form of permit-registration and other such actions; making binding decisions on individuals in the process of addressing so-called "public needs" (such as land acquisition, construction of roads, bridges, etc.). The scientist emphasized that the executive power is realized not only in the form of state administration, but also in various other forms of state activity, which is entity to regulation by administrative law ${ }^{16}$.

Scientific approach of academician Averianov V.B. reveals the essence of the activity of executive bodies as a multidimensional one, which is not limited to purely power-organizing and proper administrative functions.

15 Административное право России: курс лекций / К. С. Бельский [и др.]; под. ред. Н. Ю. Хаманевой. - М.: ТК Велби, Изд-во Проспект, 2008. - 704 с.

16 Авер'янов В. Б. Вибрані наукові праці под ред. Ю. С. Шемшученко, О. Ф. Андрійко. - К.: Інст-т держави і права ім. В. М. Корецького НАН України, 2011. $448 \mathrm{c}$. 
However, if we consider the opinion of Salishcheva N.G. regarding the essence of state-governmental authority, it is possible to point out the expediency of attributing the activity of the executive authorities to the application of measures of administrative coercion to law enforcement activity, which is aimed at ensuring legality and discipline.

From the above scientific controversy on the nature and content of the basic categories of science of administrative law, we can distinguish the established position, the content of which there are no fundamental contradictions - the provision of law enforcement as one of the main functional types of state (Averyanov V.B.) and the main organic connection of the functions of executive bodies with state-power powers (Averyanov V.B.) ${ }^{17}$. In this approach, administrative oversight should be considered as one of the varieties of the basic functional type of lawenforcement activity, which has its own purpose and object within the general direction of the administrative (executive) activity of the executive power holders, which advocates the realization of citizens' constitutional rights and protection of their rights. and freedoms.

The executive holder is the executive body. The part of the state apparatus (organization) is defined by him, and this state apparatus has its own structure and staff, territorial scope of activity, is formed in the statutory or other legal acts, in the manner and within the limits of the envisaged competence, performs on behalf of the state the functions of public administration in economic, social -cultural, administrative-political spheres of public life ${ }^{18}$. Similar to the list of features (traits) of the executive authority, and therefore the essence of the definition of the corresponding concept is provided by Chetverikov V.S. ${ }^{19}$.

Such a definition is complemented by the inclusion in it of the features (features) of structuring by departments and positions occupied by public servants, and by the constitution and laws of Ukraine in the system of bodies of executive power. The body of executive power is an organizationally independent element of the state apparatus (mechanism of the state), which is endowed with a clearly defined scope of powers (competence) in accordance with the tasks and functions assigned to it, consists of structural units and

17 Адміністративне право України. Академічний курс: Підруч.: У двох томах: Т. 1. Загальна частина / Ред. колегія: В. Б. Авер'янов (голова) та ін. - К.: ТОВ “Видавництво “Юридична думка", 2007. - 592 с.

18 Адміністративне право [Текст]: підручник/ Ю. П. Битяк (кер.авт.кол.), В. М. Гаращук, В. В. Богуцький та ін. ; за заг.ред. Ю. П. Битяка, В. М. Гаращука, В. В. Зуй. - Х. : Право, 2010. - 624 с.

${ }_{19}$ Четвериков В. С. Административное право: ученик/ В. С. Четвериков. - М.: Эксмо, 2010. -608 c. 
positions occupied by civil servants, and is classified by the Constitution of Ukraine to the system of executive authorities.

Scientists also identify the following attributes of the executive power: the creation for the purpose of direct implementation of a specific type of state activity; performance of activities characterized by a clearly defined state orientation, goals, objectives and functions; implementation of activities using state-defined methods and forms. An important feature of the executive authority is the establishment of its legal form of legal personality, which gives the right to enter and participate in certain legal relationships.

Summarizing of scientific provisions mentioned above allows us to distinguish the following features (features) of the executive authority:

- is part of the state apparatus and is referred to by the Constitution and laws of Ukraine as a system of executive bodies;

- has legal status, acts as a holder of state-power powers, which he implements in connection with the implementation of public administration in the socio-economic and other spheres of society;

- has the legal form of a legal entity;

- created for the purpose of direct implementation of a specific type of state activity using state-defined methods and forms;

- within the system of bodies of executive power is endowed with operational autonomy, which is expressed in entities of authority, rights, duties, territorial limits of activity of each individual body;

- the activity is subordinate, executive and administrative in nature;

- it is structured by units and positions occupied by civil servants;

- financing of activities is carried out from the state budget.

The body of executive power is appropriate to name the part of the state apparatus, structured according to the units and positions occupied by civil servants, created with the purpose of direct realization of a specific type of state activity by means of the state-defined methods and forms and referred to by the Constitution and laws of Ukraine in the system of bodies of executive power.

Characterizing the executive authorities as entities of administrative law, it should be pointed out to the well-established scientific opinion that the entity of administrative law can be only the one that has the potential ability to enter into legal relations. At the same time, the proposed approach to the definition of the entity of administrative law does not actually contradict the existing developments. This determines the paramount role in establishing the content of the administrative-legal relations of their parties (entities). Such parties are the entities of administrative law, they are the holders of the administrative and legal norms of rights and obligations that are capable of exercising these rights, and the assigned duties. In this way, not only the potential ability to be 
the holder of administrative and legal powers, but also the ability to exercise these powers is actually indicated.

Based on the information mentioned above, it is advisable to provide a narrow and wide understanding of the category of "entity of administrative law". In the wide, this category covers not only the potential to enter into legal relationships, but also the exercise of the rights and obligations conferred by an administrative rule. In a narrow sense, the category of "entity of administrative law" encompasses the potential for legal capacity.

The primacy of the wide view of the essence of the category "entity of administrative law" allows the application of the category of "entity" to all participants of administrative and legal relations, regardless of whether they are potential participants, or actually participate in such legal relations.

In this approach, it is possible to formulate the concept of executive authority as an entity of relations in the field of administrative oversight.

The executive body as the entity of relations in the field of administrative supervision - part of the state apparatus, empowered with the administrative norms of rights and responsibilities in the relations with the administrative supervision as a separate type of state-governmental, executive activity, thereby generating such relations, in who appear to be a potential or a real party.

The signs of the executive authority as the entity of relations in the field of administrative supervision are derived from the most essential features of the executive authority, identified by scientists. The difference lies in the specific nature of the relations in the field of administrative supervision as a stategovernmental activity aimed at establishing the conformity of the state of the supervised object with the current legislation without interfering with its activity. Such specificity determines the content of the activity of the executive authorities in the sphere of administrative supervision, the competence in the relevant relations and the limits of its implementation. The characteristics of the executive branch of the legal supervisory relationship should also be taken into account.

Therefore, the most essential features of an executive authority as a legal entity in the area of administrative oversight should be identified as follows:

- is a legal entity separated by legal status;

- acts on behalf of the state and for the performance of functions of the state;

- the administrative capacity of a body of executive power is defined by legal status as a holder of state-power powers in connection with the exercise of administrative supervision;

- has administrative legal personality, defined by legislative acts, the rules of which regulate relations in the exercise of administrative supervision; 
- realizes administrative legal personality within the limits of carrying out administrative supervision as administrative activity of special character;

- activities aimed at ensuring legality and discipline;

- predominantly endowed with the power to resolve a case-by-case and to make a legally binding decision, binding on the addressees of the order;

- the decision taken by the executive authority on the consequences of administrative supervision, causes for the addressees of the prescriptions certain restrictions, stipulated by the legal norm.

Characterizing the executive authorities as entities of administrative oversight, it is necessary to point out their main feature as the presence of state-power powers.

In particular, Bevzenko V.M. characterizes the content of a power management function as a criterion for determining the entity of power, substantiates the relevant category, establishes the types of entities and the form of their participation in administrative justice. Based on the existing scientific achievements of scientists determines the following features of managerial functions: a) it is one of the types (directions) of a conscious, volitional, active, purposeful activity of a public authority, local selfgovernment body, their official or official person, other authorized entity; b) it is part of the content of management activity, relatively independent and homogeneous; c) power-organizing, regulatory influence, which in the established forms and methods and in a certain procedure is exercised by authorized entities, expresses the power-organizational nature of management, and the purpose of influence, in general, is to streamline a certain type of social relations, bringing them in line with the needs of society, the state, the focus of management functions on ensuring the vital needs of the management object; d) the presence of each function of a managerial function, the performance of which ensures the performance of the current task, the exercise of a legal duty, and therefore the management function is a kind of means, a way of exercising the rights and duties entrusted to an authorized entity; e) establishing by law the types, content and procedures of performing management functions; f) the exercise of managerial functions solely within the limits of the public powers conferred; g) identification of the content and procedure for the implementation of a specific managerial function in the development, drafting and execution of various regulatory, individual and other acts, as well as the manifestation of management functions in the exercise of physical-mental, procedural nature - coordination of joint actions, verification, introduction to databases, etc.; h) the implementation of managerial functions in the relationship between the entity and the object of management; i) the logical connection between the previous performance of administrative and subsequent functions, the interconnection and 
interdependence of functions with each other, the formation of their implementation of continuous, long, heterogeneous procedural activities of an authorized entity (state authority, local government, their official, another entity); j) ensuring the exercise of the administrative function and its effectiveness by the coercive power of the state, on whose behalf the relevant authorized entity acts.

The managerial function is the purposeful, procedural, by-law activity of an authorized entity (state authority, local self-government body, their official or official person, other entity), which should ensure the fulfillment of its tasks by the relevant entity, meeting the needs of society or the state. The list of basic management functions includes: forecasting, planning, organization, coordination, control, accounting, motivation ${ }^{20}$.

Scientific approach Bevzenko V.M. is built on the legal essence of the category of "functions of public administration", which allows to take into account the orderly content of management activities and the established approach to determining the essence of management. In the development of existing work, the researcher proposes to introduce a legal procedure under which the managerial function should be implemented. Taking into account this theoretical shortcoming allows you to: firstly, to apply the theoretical model of the formed features of the managerial function to the analyzed legal phenomena in order to distinguish similar functions and, secondly, to establish the existence of legal procedures for the implementation of the respective functions. In this case, the proposed Bevzenko's V.M. theoretical construction of "public function" is wide and covers all the functions entrusted to entities that fall into the category of public: public authorities, local governments, public organizations. According to information mentioned above, it is difficult to establish the feasibility of a theoretical construction with such a wide content.

The systematic and dynamic content of the content of the term "authority" determines the need to analyze the category of "authority", which suggested the use of Yampolska Ts.A. In her view, authority should be considered from the standpoint of the status of a state body. This approach does not contradict the provisions formulated by Tykhomirov Yu., who indicated that the power of the state actually consists of a number of inextricably linked elements, among which the most important are the following:

a) the issuance of statutes by the state - legal acts that are binding on all citizens and officials;

20 Бевзенко В. М. Участь в адміністративному судочинстві суб'єктів владних повноважень: правові засади, підстави та форми: монографія / В. М. Бевзенко. - К. : Прецедент, 2010. - 475 с. 
b) protection of these orders from violations by the coercive power of the state;

c) ensuring the enforcement of orders by education, persuasion;

d) the material support of the execution of state orders through the disposal of a single state property fund ${ }^{21}$.

Proposed elements by Tykhomyrov of power are the basis for establishing meaningful characteristics of power, such as state orders issued within the competence, binding and protected by the coercive power of the state.

The substantive characteristics of ownership substantiated above are also characteristic of administrative supervision.

Haraschuk V.M. noted correctly, that in the system of control and supervisory activity, the executive authorities have the most essential powers. This is due to the fact that the system of designated bodies is created by the state for the day-to-day (continuous) management activities, of which, as already noted, is oversight. The management process constantly requires, in addition to scientific forecasting, the correction and correction of the "course", the finding and elimination of deficiencies that occur periodically along the way. Each executive body, its officials, within the limits of their powers, control the implementation of the decisions taken, the observance of the legislation in the activities of a particular system, individual structural unit or industry. Such control may relate to both the internal aspects of the system and its external relations ${ }^{22}$.

\section{CONCLUSIONS}

The analysis of scientific views on the definition of categories, which denote the functional and subjective constituent of the executive power, allowed to form an approach on the essence of the executive power and the place of administrative supervision in the executive power.

Pointing to the essence of executive power it should be based on a scientific approach established in the science of administrative law, which provides for its disclosure in the light of the principle of separation of state power as one of the functional types of activity of the state - the implementation of laws by authorized entities - holders of executive power. The relevant activity is defined as administrative (executive). Administrative supervision is one of the varieties of the specified functional activity of the

${ }^{21}$ Тихомиров Ю. А. Теория компетенции. - М.: Юринформцентр, 2001. - 355 с.

22 Гаращук В. М. Теоретико-правові проблеми контролю та нагляду у державному управлінні : автореф. дис.. на здобуття наук. ступеня доктора юридичних наук : спец. 12.00.07 - теорія управління; адміністративне право і процес; фінансове право / Володимир Миколайович Гаращук ; Національна юридична академія України ім.. Ярослава Мудрого. Харків, 2003. - 35 с. 
state, which has its own purpose and object within the general orientation of the administrative (executive) activity of the holders of executive power.

Administrative supervision should be defined as part of the executive activity of the authorized bodies of the state executive power, other entities (their officials), empowered with the administrative legal authority to establish the extent and degree of compliance of the activity of the entity to administrative supervision to the current legislation, and also guaranteeing safety in certain spheres of life of the population, which is a relatively separate, power-organizing, implementation procedures established by current legislation. Administrative oversight procedures include the development, drafting of individual legal acts, and the taking of organizational actions in order to fulfill the tasks assigned by the current legislation to an entity, authorized to carry out administrative supervision. Administrative enforcement is ensured by the coercive power of the State on whose behalf the relevant authorized entity acts.

\section{SUMMARY}

The most essential features of the executive authority as the entity of legal relations in the field of administrative supervision are: separated by the legal status of the entity of administrative and legal relations; acts on behalf of the state and performs the functions of the state; the administrative capacity of a body of executive power is defined by legal status as a holder of state-power powers in connection with the exercise of administrative supervision; has administrative legal personality, defined by legislative acts, the rules of which regulate relations in the exercise of administrative supervision; realizes administrative legal personality within the limits of carrying out administrative supervision as administrative activity of special character; aimed at ensuring legality and discipline; predominantly endowed with the power to resolve an individual case and make a legally binding decision, binding on the addressees of the order; such a decision taken by an executive authority following the effects of administrative oversight causes certain recipients of the injunctions prescribed by the rule of law. On the basis of signs of administrative supervision, determinations of distinction between control and supervision in methodological and normative values the concept of administrative supervision of executive bodies is set forth. Leaning against approach of the systems, expediency of description of subjects of administrative supervision is well proven in three aspects: structuralfunctional, synergetics and responsible. Classification of subjects of administrative supervision is offered not only on the sign of competence but also after character of the article of realization. The concept of principles of administrative supervision is reasonable, general and special principles are distinguished. Systematization of methods of administrative activity is conducted in relation to realization of supervision National Policy. 


\section{REFERENCES}

1. Виконавча влада i адміністративне право / За заг.ред. В. Б. Авер'янова. - К.: Видавничий Дім “Ін Юре”, 2002. - 668 с.

2. Денисова А. В. Сущность и содержание базовых категорий административного права: отдельные проблемы определения / А. В. Денисова // Legea si Viata. - 2017. - № 3/2 (303). - С. 57-60.

3. Золотарьова Н. I. Співвідношення виконавчої влади та адміністративної діяльності / Н. І. Золотарьова // Вісник Національного технічного університету “КПІ”. - 2011. - № 1 (9). - С. 45-54.

4. Гробова В. П. Адміністративний аспект державного управління / В. П. Гробова // Актуальные проблемы права : теория и практика. Сборник научных трудов. - 2010. - № 18. - С. 298-304.

5. Державне управління : навч. посіб. / [Мельник А. Ф., Оболенський О. Ю., Васіна А. Ю., Гордієнко Л. Ю. та ін.] ; під ред. А. Ф. Мельник. - К. : Знання-Прес, 2003. - 343 с.

6. Синкова О. М. Підзвітність в системі органів виконавчої влади: організаційно-правові проблеми: дис..д.ю.н. 12.00.07 / Синкова Олена Михайлівна/ Інститут держави і права ім.. В. М. Корецького НАН України. - К., 2011. - 400 с.

7. Рябченко О.П. Концептуальні проблеми застосування диспозитивного методу публічно-правового регулювання відносин у сфері економіки / О. П. Рябченко: наукова доповідь. - К.: Логос, 2013. $-40 \mathrm{c}$.

8. Денисова А. В. Сутність адміністративної діяльності щодо здійснення нагляду органами виконавчої влади та їі місце у виконавчій владі / А. В. Денисова // Актуальні проблеми держави і права. - 2017. Випуск 79. - С. 46-50.

9. Курс адміністративного права України: підручник / В. К. Колпаков, О. В. Кузьменко, І. Д. Пастух, В. Д. Сущенко [та ін.] / за ред. В. В. Коваленка. - К.: Юрінком Інтер, 2012. - 808 с.

10. Вітвіцький С. С. Контроль діяльності публічної адміністрації в Україні: теорія i практика [монографія] / С. С. Вітвіцький. Дніпропетровськ: Дніпропетровський державний університет внутрішніх справ, 2015. - 362 с.

11. Великий енциклопедичний юридичний словник / За ред.. акад.. НАН України Ю. С. Шемшученка. - 2-ге вид., переробл. і доповн. - К.: Вид-во “Юридична думка", 2012. - 1020 с.

12. Теорія держави i права: підручник / О.В. Петришин, С. П. Погребняк, В. С. Смородинський та ін.; за ред. О. В. Петришина. Х.: Право, 2015. -368 с. 
13. Любченко М. І. Юридична термінологія: поняття, особливості, види: монографія / М. І. Любченко. - Х.: ТОВ "Видавництво права людини", 2015. - 280 с.

14. Чан Тхуи Ван. Организационно-правовое обеспечение туризма во Вьетнаме (сравнительный анализ с Украиной): дис.к.ю.н. 12.00.07 / Чан Тхуи Ван / Инстиут государства и права им. В. М. Корецкого НАН Украины. - К., 2016. - 206 с.

15. Административное право России: курс лекций / К. С. Бельский [и др.]; под. ред. Н. Ю. Хаманевой. - М.: ТК Велби, Изд-во Проспект, 2008. - 704 c.

16. Авер'янов В. Б. Вибрані наукові праці / [ред. Ю. С. Шемшученко, О. Ф. Андрійко]. - К.: Інст-т держави і права ім. В. М. Корецького НАН України, 2011. - 448 с.

17. Адміністративне право України. Академічний курс: Підруч.: У двох томах: Том 1. Загальна частина / Ред. колегія: В. Б. Авер'янов (голова) та ін. - К.: ТОВ “Видавництво “Юридична думка", 2007. - 592 с.

18. Адміністративне право [Текст] : підручник / Ю. П. Битяк (кер.авт.кол.), В. М. Гаращук, В. В. Богуцький та ін. ; за заг.ред. Ю. П. Битяка, В. М. Гаращука, В. В. Зуй. - Х. : Право, 2010. - 624 с.

19. Четвериков В. С. Административное право: ученик / В. С. Четвериков. - М.: Эксмо, 2010. -608 с.

20. Бевзенко В. М. Участь в адміністративному судочинстві суб'єктів владних повноважень: правові засади, підстави та форми: монографія / В. М. Бевзенко. - К. : Прецедент, 2010. -475 с.

21. Тихомиров Ю. А. Теория компетенции. - М.: Юринформцентр, 2001. $-355 \mathrm{c}$.

22. Гаращук В. М. Теоретико-правові проблеми контролю та нагляду у державному управлінні : автореф. дис.. на здобуття наук. ступеня доктора юридичних наук : спец. 12.00.07 - теорія управління; адміністративне право i процес; фінансове право / Володимир Миколайович Гаращук ; Національна юридична академія України ім. Ярослава Мудрого. - Харків, 2003. - 35 с.

\section{Information about the author:}

Denysova A. V.,

Doctor of Law, Associate Professor, Head of the Department of Administrative Law and Administrative Process, Odessa State University of Internal Affairs 1, Uspenska str., Odessa, 65000, Ukraine 
DOI https://doi.org/10.36059/978-966-397-178-0/49-65

\section{THE RATIO OF THE CIVIL AND CIVIL-PROCEDURAL LEGAL RELATIONS IN THE SCIENCE OF CIVIL PROCEDURAL LAW}

\section{Didenko L. V.}

\section{INTRODUCTION}

In society there is always a wide variety of relationships between people and their associations, resolved or not resolved rules of law: economic, political, moral, spiritual, cultural, civil, family etc. The scientific relationship between them is often related to such categories as "activity", "user", "rule of law". In addition, different types of relationships differ. The issue of cooperation between civil law and civil procedure relations is new for the domestic legal science, which today is civilized and considers issues that do not consider the issue in such a context. So far, the ratio of civil and civil procedural legal relations has not been carried out within the framework of scientific research. At the same time, a number of scientists carried out comparisons of categories of civil and civil procedural law, civil law and civil procedure norms, and also established the concept of civil law and civil procedure legal relations, the definition of the essence of which makes it possible to correlate both categories. Such researchers include, first of all, such as: I.S. Andriyenko, Y. Belousov, S. Vasiliev, A.V. Getmantsev, K.V. Gusarov, T.M. Kilichawa, V.V. Komarov, Z. Lazko, A.L. Paskar, A.V. Pidlubnaya, P.I. Radchenko, L. Tychynski, E.I. Fursa, S.Y. Fursa, T.V. Tsyura, S.I. Chernoochenko, M.I. Stefan, S.V. Scherbak, M.M. Yasinok etc. However, directly establishing the relations between the civil law and civil procedural legal relations in scientific research by these authors was not done, which determines the relevance of research on a given topic.

\section{Relationship between civil law and civil procedural law}

Ratio is the mutual relation, mutual connection, mutual dependence of different values, objects, events. That is, setting the ratio civil-law and civilprocedural relations, we are primarily defined by their mutual relation to each other, mutual connection and dependence.To establish this relationship, you first need to figure out how to relate to civil procedure law and civil law, because the regulatory force of their norms revealed in the regulation of appropriate relations. The expediency of the study of the ratio of civil procedure and civil law is also confirmed in the work of A.V. Podlubnyi, who, by correlating civil procedure norms and civil legal relations, came to the conclusion that they are interrelated forms of law existence. The norm of law 
transforms public relations into legal, that is, a prerequisite for the emergence of legal relations, and the latter, in turn, is a way to implement in practice the norms of law and help the norms to influence public relations. In other words, the norms of civil procedural law are the primary links of the system of civil process, one of the ways of implementation of civil procedural relations in practice and a tool through which the impact on public relations is carried out ${ }^{1}$. Taking into account the interconnectedness of civil procedural norms and civil legal relations, we conclude that it is advisable to analyze the relationship between civil procedural law and civil law in order to achieve the goals of this study.

Thus, M.I. Stefan notes that the link between civil procedural law and civil and other branches of substantive law is determined by the need to enforce the norms of substantive law by the judiciary. That is, civil procedural law is a form of ensuring the vital activity of the norms of substantive law, protection and their enforcement. In particular, part 1 of Article 19 of the current Civil Procedural Code of Ukraine states that the courts consider in the order of civil proceedings cases arising from civil, land, labor, family, housing and other legal relations, except for cases, consideration of which is carried out in the order of other legal proceedings. Also, as noted by M.I. Stefan, the link between civil procedure and civil law is manifested in the existence of a coercive apparatus capable of enforcing compliance with the norms of civil law - the court, the order of which is regulated by the norms of procedural law in the consideration and resolution of civil cases; as well as in certain norms and institutions of civil law - in particular, those that determine the circumstances, the totality of legal facts that constitute the basis of the claim, the subject of proof and are subject to clarification in civil proceedings when considering specific references ${ }^{2}$. From all of the above we can conclude that the relationship between civil and civil procedural legal relations, according to the position of M.I. Stefan, is as follows:

1) civil procedural legal relations arise in the presence of disputable nature in civil legal relations;

2) in the case when the subject of civil legal relations is a court, such legal relations turn into civil procedural ones. At the same time, the activities of the court are regulated by the norms of civil procedural law, and the cases that are considered by it are regulated by the norms of civil law;

${ }^{1}$ Теоретичні проблеми цивільного процесуального права : підручник / М. М. Ясинок, М. П. Курило, О. В. Кіріяк, О. О. Кармаза, С. І. Запара та ін.; за заг. ред. д.ю.н. професора М. М. Ясинка. К. : Алерта, 2016.

${ }^{2}$ Штефан М. Й. Цивільне процесуальне право України : академічний курс. К. : Ін Юре, 2005. 624 c. 
3) separate norms and institutions of civil law, respectively, are related to civil legal relations, as they determine the circumstances, the totality of legal facts that constitute the basis of the claim, the subject of evidence and are subject to clarification in civil proceedings in the consideration of specific cases.

Thus, guided by the above analyzed point of view, we can conclude that civil procedural and civil legal relations are related as a prerequisite and consequence. The existence of civil procedural legal relations is not a primary need, except in cases where coercion is necessary in civil legal relations. These legal relations differ, above all, by their subjective composition. After all, when the party to the relationship becomes a court, such legal relations can be defined only as civil procedural. Certain relations are also observed in the legal regulation of both types of legal relations, because it is the norms of civil law that determine the legal facts that are subject to clarification in civil procedural legal relations. The authors of the book "Theoretical Problems of Civil Procedure Law" under the general editorship of M.M. Yasinka explain that the ratio of civil and civil procedure law is that civil procedure law is a form of law, ensures the life of norms of civil law, protection and their enforcement ${ }^{3}$. At the same time, the researcher notes that civil procedural law without civil (or other material) law would become meaningless and lose its social and legal meaning. This position is very close to the previous one analyzed. However, we emphasize that from this point of view, the relationship between civil and civil procedural law lies in the mutual dependence of individual provisions of civil law institutions and civil procedural law. In particular, as well as in the opinion of M.I. Stefan, their ratio is that the norms of civil law determine the grounds for appeal to the court, the parties to the civil process, the range of circumstances to be proved, the rules of jurisdiction, and, accordingly, the norms of civil procedural law are the procedural order of such appeal, the types of evidence and the order of proof. However, the authors emphasize that not only the functioning of civil law depends on the procedural law, but also the existence of civil procedural law without civil law loses its sensor. Taking this into account, we can somewhat expand the conclusions made earlier in this paper on the relationship between civil and civil procedural legal relations, namely, that the links and interdependence of civil procedural legal relations and civil legal relations are two-way: civil procedural legal relations arise in the presence of a controversial nature in civil legal relations and at the same time, due to the existence of civil procedural legal relations, the life of civil legal relations is ensured, their protection, as well as their enforcement.

${ }^{3}$ Цивільний процес України : підруч. / В. О. Кучер та ін.; ред. В. О. Кучер. Львів : ЛьвДУВС, 2016. 768 с. 
Other researchers (e.g. L. Tichinska) agree with such conclusions, but do not offer alternative views ${ }^{4}$.

Thus, in the process of analysis of the scientific literature devoted to the ratio of civil and civil procedural law, we have established that civil and civil procedural legal relations are related as follows:

1) 1)relations between civil law and civil procedural legal relations are bilateral - civil procedural legal relations arise in the presence of a controversial nature in civil legal relations, and due to the existence of civil procedural legal relations, the life of civil legal relations is ensured, their protection and enforcement;

2) 2)when the court enters into civil legal relations, such legal relations turn into civil procedural ones. At the same time, the activities of the court are regulated by the norms of civil procedural law, and the cases that are considered by it are regulated by the norms of civil law;

3) certain norms and institutions of civil law are also relevant to civil procedural legal relations, because they determine the circumstances, the totality of legal facts that constitute the basis of the claim, the subject of proof and are subject to clarification in civil proceedings in the consideration of specific cases: The norms of civil law define the grounds for appeal to the court, the parties to the civil process, the range of circumstances to be proved, the rules of jurisdiction, and accordingly the norms of civil procedural law are the procedural order of such appeal, the types of evidence and the order of proof.

We conclude that the above features are sectoral criteria for the ratio of civil law and civil procedural legal relations, because their allocation follows from the features of the ratio of branches of law, within which they are implemented. However, the ratio consists not only in establishing mutual relations and mutual dependence of different phenomena or concepts. The ratio also consists in defining the distinguishing features that distinguish one institution from another. Therefore, we propose to distinguish special criteria of differentiation between civil and civil procedural legal relations, the essence of which follows from the legal nature of each of the institutions. For example, N.Y. Golubeva, studying the ratio of mandatory and proprietary legal relations, defined the following criteria by which they differ from each other: 1) by the circle of related persons; 2) by the object; 3 ) by the grounds of origin; 4) by the specific form in which the rights and respective obligations of the parties are expressed; 5) by the peculiarities of subjective law; 6) by the

\footnotetext{
${ }^{4}$ Тичинська Л. А. Правові засади цивільного процесуального права: співвідношення 3 іншими галузями права в умовах розбудови правової держави. Європейські перспективи. 2014. № 4. C. 121-123.
} 
nature of implementation; 7) by the peculiarities of legal regulation; 8) by the value for civil turnover; 9) by the time of existence; 10) if necessary, the interaction of the parties; 11) by property or non-property nature ${ }^{5}$.

The following conclusions will be drawn from this position:

1) 1)it has enough general character, that is it can be applied not only for an establishment of parities between obligatory and material legal relations, but also for differentiation of civil and civil procedural legal relations or other kinds of legal relations;

2) 2)since the ratio of different types of legal relations does not enjoy popularity among domestic scientists, we propose to be guided in our study by the majority of the above-mentioned criteria, except for those that are more of a special nature (for example, the establishment of a ratio of civil law and civil procedural legal relations on the meaning for civil turnover does not seem to be appropriate and possible).

Thus, our research allows us to conclude that the ratio of civil and civil procedural legal relations should be carried out according to the following criteria:

1) by the circle of persons related to them;

2) by object;

3) on the grounds of occurrence;

4) in a specific form in which the rights and respective obligations of the parties are expressed;

5) by peculiarities of subjective law;

6) by the nature of the subjects' exercise of their rights;

7) on peculiarities of legal regulation;

8) by the time of existence;

9) if necessary, interaction between the parties;

10) by legal nature (property or non-property).

\section{Criteria for the ratio of civil law and civil procedural relations}

Accordingly, to determine how is the relationship of civil and civilprocedural legal relations, it is worth to analyze the characteristics of each of them within selected guidelines.

1. In a circle of related persons. A.S. Mazur notes that each civil legal relationship involves at least two subjects, which are its participants, who are also called persons. The subject of civil legal relations, to which the right belongs, is called the subject of law, and the subject of civil legal relations, to

5 Діденко Л. В. Співвідношення цивільно-правових та цивільно-процесуальних відносин. Науковий вісник Ужгородського національного університету. Серія: Право. 2016. Вип. 41. Т. 4. С. 146-149. 
which the duty is assigned - a passive subject. In civil legal relations, each of the participants has subjective rights and bears subjective duties (for example, in civil legal relations arising from contracts of sale, each of the subjects of legal relations has rights and bears duties) and should be a legal entity, that is, possess the ability to be a party to civil legal relations. A.S. Mazur also points out those subjects that may be participants of civil legal relations - citizens of Ukraine, foreign citizens, stateless persons, legal entities (state enterprises and institutions, cooperatives, public organizations, joint-stock companies, rental companies), the state of Ukraine, other organizations (for example, religious organizations, joint ventures with the participation of Ukrainian and foreign legal entities, foreign enterprises and organizations). That is, in this case, we note the absence of special subjects that are unique to this type of legal relations. In general terms, there is a wide range of persons who are subjects of civil law.

As for the subjects of civil and procedural legal relations, the analysis of the norms of Chapter 4 of the Civil Procedural Code of Ukraine shows that they are primarily related to them ${ }^{6}: 1$ ) participants of the case (including presbyters of the parties); 2) other participants of the trial. However, as the author of the textbook "Theoretical Problems of Civil Procedure Law" under the editorship of M.M. Yasynka aptly points out, civil procedure law does not distinguish the court or bodies administering justice as a separate group of subjects, however, based on the constitutional provisions on legal proceedings and general principles of justice, we can conclude that it is the court that will play a leading and decisive role in the judicial process. That is why the third group of subjects of civil procedural legal relations should include the court as a subject whose exclusive function is the administration of justice. Analysis of the provisions of Chapter 3 of the Civil Procedural Code of Ukraine shows that this group of subjects belongs to this group: 1) a judge is a sole person who is the chairman and acts on behalf of the court; 2) a collegial composition of the court consisting of one judge and two jurors; 3 ) a collegial composition of the court of appeal consisting of three judges; 4) a collegial composition of judges of the court of cassation consisting of three or more odd number of judges; 5) a judicial chamber of the Civil Court of Cassation (chamber), a united chamber of the Civil Court of Cassation (united chamber) or the Grand Chamber of the Supreme Court (the Grand Chamber). Participants in the case are individuals and legal entities, the State of Ukraine, the Autonomous Republic of Crimea, territorial communities, foreign states, public authorities (central and local), local governments, public authorities of the Autonomous Republic of Crimea, public institutions (foundations and institutions), public

${ }^{6}$ Цивільний кодекс України : Закон України від 16.01.2003 № 435-IV. Відомості Верховної Ради Украӥни. 2003. № 40. Ст. 356. 
institutions (foundations and institutions), public and public enterprises, public utilities. Such a conclusion can be made taking into account the subjects of civil legal relations.

Any subject of civil legal relations can become a subject of civil procedure if there is a need to protect violated, unrecognized or disputed rights, freedoms or legitimate interests.

At the same time, the subjects of civil procedural relations can be much wider circle of people. According to article 56 of the CPC of Ukraine to subjects should include bodies and persons who legally have the right to go to court in the interests of other parties (state authorities, local self-government bodies, physical persons and legal entities, the Ukrainian Parliament Commissioner for human rights), as well as representatives. Other participants, in accordance with paragraph 3 of Chapter 4 of the CCP, is the assistant judge, court clerk, court bailiff, witness, expert, expert on law, a translator, a specialist.

So, correlating civil and civil procedural legal relations on criterion of a circle of the persons connected by them, we come to a conclusion that in civil procedural legal relations the wider circle of persons can participate much wider. Specific subjects are, first of all, the court as a subject, the exclusive function of which is the administration of justice, bodies and persons, which by law are granted the right to appeal to the court in the interests of other persons and representatives. Also, the subjects of civil and procedural legal relations should include a special category of subjects who are participants in the trial, but are not parties to it - assistant judge, secretary of the court session, court administrator, witness, expert, legal expert, interpreter, specialist.

2. The object. The object in general theoretical understanding is a phenomenon, a subject, a person to which a certain activity aspires, attention is longing. That is, the object of legal relations is what they arise and exist for. V.I. Borisova, I. Spasibo-Fateeva, and V.L. Yarotsky note that the issue of the object of civil legal relations is one of the most complicated in the theory of civil law. Since all civil legal relations arise in relation to a certain property or non-property benefit, the Civil Procedure Code of Ukraine singles out the property object of civil legal relations and non-property object ${ }^{7}$. Property objects of civil legal relations are: 1) things; 2) money; 3) securities; 4) property rights, results of some types of human activity (works and services - for example, a house was built, a thing, a costume was repaired, etc.). Non-material objects of civil legal relations are referred to as non-property objects: 1) results of

${ }^{7}$ Цивільний процес України : підруч. / В. О. Кучер та ін.; ред. В. О. Кучер. Львів : ЛьвДУВС, 2016. 768 с. 
human intellectual activity or objects of intellectual property rights (works of science, literature, art, discoveries, inventions, etc.); 2) information; 3) personal non-property benefits (honor, dignity, business reputation, name, image, privacy, etc.). Accordingly, in general terms, civil procedure relations arise in relation to these very benefits, but in this case they are not the object of legal relations. As defined by T.M. Kilichava, the object of civil procedural legal relations is the public relations on protection of the violated material right or interest protected by the law in court. It follows that civil legal relations arise in relation to a certain property and personal non-property right or interest protected by law. In turn, the basis for the emergence of civil procedural legal relations is the violation of such a right. That is, according to the criterion of the object of legal relations, civil and civil procedural legal relations are related as a prerequisite and as a consequence. It is impossible to violate this right or interest without the occurrence of a corresponding right or interest. Accordingly, the protection of violated rights and interests is the only object of civil and procedural legal relations ${ }^{8}$.

3. On the grounds of origin. It is generally accepted that any legal relations arise, change and terminate on the basis of legal facts, i.e. certain circumstances and facts of reality. Thus, the legal fact is the main condition for the emergence of both civil and civil procedural legal relations. The list of legal facts, with the onset of which the emergence of civil legal relations, is enshrined in Article 11 of the Civil Code of Ukraine, and they are referred to them: 1) contracts and other transactions; 2) creation of literary, artistic works, inventions and other results of intellectual activity; 3) infliction of property (material) and moral damage to another person; 4) other legal facts. We note the phrase "other legal facts", which demonstrates the inexhaustibility of this list. This means that civil legal relations may arise both on the grounds provided by Article 11 of the Civil Code of Ukraine and on other grounds. This is partially disclosed in the following parts of the article, which, in particular, establish that civil rights and obligations may arise directly from acts of civil law, acts of state authorities, the Autonomous Republic of Crimea, local self-government bodies and court decisions. Also, the basis for the emergence of civil rights and obligations may be the onset or nonoccurrence of a certain event. Therefore, we can conclude that the grounds for the emergence of civil legal relations are a wide range of legal facts, different in nature, which are inexhaustible in nature, that is, their list is much broader than that which is enshrined in Article 11 of the Civil Code of Ukraine.

${ }^{8}$ Цивільний процес України : підруч. / В. О. Кучер та ін.; ред. В. О. Кучер. Львів : ЛьвДУВС, 2016. 
The basis for the emergence of civil procedural legal relations is much more difficult, and several researchers defined as the following set of elements: 1) norms of civil procedural law; 2) civil procedural legal capacity of participants in civil proceedings; 3 ) procedural legal facts. According to the works of these authors, the rule of law as a prerequisite for the emergence of civil procedural legal relations can be established exclusively by the state, is mandatory, has a general nature, regulates social relations exclusively in the field of administration of justice in civil cases, aims at comprehensive and timely consideration and resolution of civil cases etc. In turn, civil procedural legal capacity is the ability to have civil procedural rights and obligations ${ }^{9}$. Specificity of legal procedural facts is that such circumstances are directly related to the realization of the right to appeal to the court for the protection of violated or disputed subjective substantive law or interest, that is, with the opening of proceedings on the case in the trial court, stages of appeal or cassation proceedings to review decisions on newly discovered circumstances etc.

That is, the main difference between the grounds for the emergence of civil law and civil procedural legal relations is that for the emergence of the first only the presence of a legal fact is necessary. The list of legal facts clearly regulated by law, and it can be complemented by other legal facts, provided that they will contribute to the emergence of civil rights and obligations. In turn, the emergence of civil procedural legal relations implies the need to comply with several conditions at once. The presence of a legal fact, which, we note, in this case has its own specifics, is not the only reason for the emergence of civil procedural legal relations, because it is necessary to have an appropriate norm of law and legal capacity of the subject. Therefore, according to the criterion of the basis for the emergence of civil procedural legal relations is much more difficult on civil law.

4. A specific form in which the rights and respective obligations of the parties are expressed. In the context of civil relations, the form in which the rights and respective obligations of the parties are expressed is the deal, i.e. the action of a person aimed at acquisition, change or termination of civil rights and obligations. Deals can be unilateral and bilateral or multilateral (agreements). A unilateral transaction is the action of one party, which may be represented by one or more persons. Such deal creates obligations only for the person who has performed it, and for other persons the obligations can be created only in cases established by law or agreement with these persons. Accordingly, a two- or multilateral transaction is a concerted action by two or

\footnotetext{
2006.

${ }^{9}$ Мазур О. С. Цивільне право України : навч. пос. К.: Центр навчальної літератури,
} 
more parties. The deal may be made orally or in writing (electronically), and the parties are entitled to choose the form of the transaction, unless otherwise provided by law. The deal may be made orally or in writing (electronically), and the parties are given the right to choose the form of the deal, unless otherwise provided by law. The deal for which the law does not provide for a mandatory written form, shall be deemed to have been concluded if the conduct of the parties certifies their will to have the relevant legal consequences, and in cases stipulated by the contract or law, the will of the party to conclude the deal may be expressed in silence. In other words, the form in which the rights and respective obligations of the parties to civil relations are expressed is oral or written (electronic) transaction, and a mandatory written form may be established by law, but there is no rule of mandatory written nature.

The form in which the rights and respective obligations of the parties in civil procedural relations are expressed is a judicial decision. According to Article 258 of the Civil Procedural Code of Ukraine, court judgments are determinations, decisions, resolutions and court orders. By passing resolutions the court resolved the procedural issues associated with the movement of the case in the court of first instance, the motions and statements of persons participating in the case, the question to postpone consideration of the case, the ad break, stay or termination of proceedings, abandonment of the application without consideration, and other cases provided for by this Code. The decision of the court ends with the consideration of the merits of the case by the trial court. The judgment is adopted as a result of the review of court decisions in the appeal and cassation procedure. Accordingly, in cases defined by law, the court proceedings may result in a ruling or a court order. The form in which the rights and respective obligations of the parties to civil and procedural legal relations are expressed is considered to be the court decisions, since their content establishes the rights and obligations of the parties to the relevant proceedings (legal relations), which each party is obliged to fulfill and observe. Also, the court decision is the basis for the restoration of violated rights of the subject of civil relations.

Therefore, we conclude that civil law and civil procedural legal relations are characterized by different forms, in which the rights and obligations of the parties are expressed. If in the first case such a form is an oral or written transaction, that is, the action of a person aimed at the acquisition, change or termination of civil rights and obligations, the form of expression of rights and obligations of the parties to civil and procedural legal relations is a court decision.

5. The peculiarities of the subjective right. Features of the subjective right of participants in civil legal relations is enshrined in Article 13 of the Civil 
Code of Ukraine, according to which a person exercises civil rights within the limits provided by the contract or acts of civil law. In exercising his or her rights, a person is obliged to refrain from actions that could violate the rights of others or cause damage to the environment or cultural heritage. Not allowed actions of the person, committed with the intent to cause harm to another person, and also abuse of right in other forms. In the exercise of civil rights, a person must observe the moral principles of society. Civil rights may not be used to unduly restrict competition, abuse of a monopoly position in the market or unfair competition. If a person fails to comply with such requirements in the course of exercising his or her rights, the court may oblige him or her to stop abusing his or her rights and apply other consequences. That is, in civil law relations the essence of subjective law is primarily reduced to the right to one's own conduct. A person receives the scope of rights, which is limited by certain boundary requirements, according to which he or she controls his or her behavior.

Under article 4 of the Code of Civil Procedure, a person applies to the courts for protection of his or her violated, unrecognized or disputed rights, freedoms or legitimate interests. That is, the subjective right of a person in civil and procedural legal relations arises as a result of the formulation of the requirement of specific behavior from other persons to stop violating the rights and interests of the person and update it in the violated rights.

6. By the nature of the implementing entities of their rights. As we have already mentioned before, in civil relations a person realizes his civil rights freely, at his own discretion, but within the limits provided to him by the contract or acts of civil law. That is, the desire to implement civil law is sufficient for their implementation. At the same time, in bilateral civil relations, it is important for the realization of human rights that the other party fulfils its corresponding duty. For example, Article 901 of the Civil Code ${ }^{10}$ of Ukraine states that under the contract for the provision of services, one of the parties (the contractor) undertakes to provide a service at the request of the other party (the customer), which is consumed in the process of performing a certain action or carrying out certain activities, and the customer undertakes to pay the contractor specified service, if the other is not established by the contract. That is, a person's right to the service may be exercised only if another person fulfils his obligations.

A person's subjective right to participate in civil and procedural legal relations is realized by the person in accordance with Article 4 of the Civil Procedure Code of Ukraine by applying to the court for protection of his

${ }^{10}$ Цивільний кодекс України : Закон України від 16.01.2003 № 435-IV. Відомості Верховної Ради України. 2003. № 40. Ст. 356. 
violated, unrecognized or disputed rights, freedoms or legitimate interests. In this context, there is no need to coordinate their actions aimed at the implementation of subjective law in such legal relations with the other party. Everyone has such a right, and its desire to realize it does not depend on the other party.

Therefore, by the nature of implementation of subjective rights by the parties, civil and civil procedural legal relations also differ significantly. If civil legal relations are characterized by the interrelation between the realization of human rights and the fulfillment of other person's obligations, then in civil procedural legal relations any person realizes his rights at his discretion, but the final result of implementation does not depend on his will, because the decision in the civil process is made by the court.

7. On peculiarities of legal regulation. The academic literature on civil law notes that civil relations may arise on the basis of both legislation and other sources. B. Yanovitskaya and V.A. Kucher are the main legal regulators of civil legal relations: civil contract, founding document of a legal entity, custom, international contract, and in cases provided by law, and court precedent ${ }^{11}$. Researchers first of all emphasize the role of contracts in civil law self-regulation (part 1-3 of article 6 of the Civil Code of Ukraine) and constituent documents of legal entities (article 87 of the Civil Code of Ukraine). Thus, the peculiarity of legal regulation of civil legal relations is that it is carried out not only by the legislative way. At the same time, at the scientific level the role and importance of individual regulators - in particular, contracts and constituent documents of legal entities - are emphasized.

Regarding civil and procedural relations, all the procedures that they assume are clearly regulated and subject to unconditional execution by the parties of legal relations, because the legal regulation of civil and procedural legal relations is carried out by the norms of the Civil Procedural Code of Ukraine. It should be noted that if the legal regulation of civil legal relations is carried out by the norms of civil law and in other ways provided by law, the civil procedural relations are regulated exclusively by law.

Therefore, we conclude that the peculiarities of legal regulation of civil and civil procedural legal relations differ. Legal regulation of civil and procedural legal relations is carried out by law, and civil - by law, civil contract, constituent documents of the legal entity, customs, international treaties, judicial precedents.

${ }^{11}$ Цивільний процес України : підруч. / В. О. Кучер та ін.; ред. В. О. Кучер. Львів : ЛьвДУВС, 2016. 
8. At the time of existence. In Chapter 18 of the Civil Code of Ukraine ${ }^{12}$ it is established that both terms and conditions apply in civil relations. The term is a certain period in time, with the expiration of which is associated with an action or event of legal significance, and the period of time is a certain point in time, the onset of which is associated with an action or event of legal significance. The term is determined by years, months, weeks, days or hours, and the time period by the calendar date or an indication of an event that must inevitably occur. If the contract between the parties is concluded indefinitely, the end of the legal relationship may be linked to the occurrence of a certain event (e.g. the withdrawal of one of the parties from an indefinite contract). Thus, civil legal relations may exist within a certain period of time, before the deadline agreed upon by the parties (including the occurrence of a certain event) or indefinitely.

In turn, there are special procedural deadlines for civil and procedural legal relations. Thus, Chapter 6 of the Civil Procedural Code of Ukraine determines that the time limits within which procedural actions are performed are established by law, and if such time limits are not determined by law - are established by the court. From this we can conclude that in contrast to the civil law, in the civil procedural legal relations there are other rules for determining the terms and time of existence of legal relations. First of all, a number of terms are directly established in the norms of the Civil Procedure Code of Ukraine. For example, in part 1 of Article 170 it is established that the debtor has the right within fifteen days from the date of delivery of a copy of the court order and attached documents to submit an application for its cancellation to the court that issued it. Another example of the terms of civil and procedural legal relations is the indication in Article 43 of the Civil Procedural Code of Ukraine that the participants of the case are obliged to perform procedural actions within the time limits established by law or by the court. That is, in this case, there is no specific term of civil and procedural legal relations, but it is established that it can be regulated in the norms of the Civil Procedural Code of Ukraine (for example, as in the above example), and directly in the court decision. So, civil and procedural legal relations exist within the period specified in the legislation.

9. If necessary, interaction between the parties. As we have already repeatedly noted in this article, the interaction of the parties in civil legal relations is necessary because the overwhelming majority of the legal relations regulated by the norms of the Civil Code of Ukraine are bilateral, and therefore require the parties to fulfill their corresponding rights and

12 Цивільний кодекс України : Закон України від 16.01.2003 № 435-IV. Відомості Верховної Ради Украӥни. 2003. № 40. Ст. 356. 
obligations. Moreover, when entering into civil legal relations, the participants themselves are interested in interacting with each other and achieving the goal of their relations.

In the same time, not all parties may be interested in civil procedural legal relations, because they arise in connection with the need to protect violated, unrecognized or disputed rights, freedoms or legitimate interests. In civil and procedural legal relations involves a much larger number of subjects, and all the procedures provided for clearly regulated in the Civil Procedural Code of Ukraine, so each party is required, above all, strict compliance with the requirements established by law. That is, in civil and procedural legal relations the term "interaction of the parties" acquires a slightly different meaning. If interaction of subjects of civil legal relations is expressed in mutual performance by them of corresponding rights and duties with a view of achievement of the purpose of joint activity in civil procedural legal relations interaction represents performance by all parties of the established legislative instructions as a result of what they get the status of subjects of corresponding legal relations. In other words, the interaction of the parties in this case loses the sign of voluntariness and is expressed in the form of a legislatively established requirement to the behavior of certain subjects.

Consequently, the need for interaction between the parties is characteristic of both civil and civil procedural legal relations. However, in both cases it takes different forms, which we have established above.

10. Legal nature of relations (property or non-property). Both civil law and civil procedural legal relations can be both property and non-property, as confirmed by the previous study. It follows from the fact that such a character is inherent in civil legal relations. Since civil legal relations is the actual reason for the existence of civil procedural relations. We will come to the conclusion that they can also be characterized by both types of legal relations.

Thus, in the process of research we have established that the criteria of the ratio of civil and civil procedural legal relations should be divided into general and special ones.

We propose to express special criteria of the ratio of civil law and civil procedural legal relations in the following way:

1) in the circle of persons related to them - a much wider range of persons participates in civil and procedural legal relations;

2) on the object - civil and civil procedural legal relations are related as a prerequisite and as a consequence. It is not possible to violate this right or interest without it. Accordingly, the protection of violated rights and interests is the only object of civil and procedural legal relations; 
3) on the grounds of origin - the main difference between the grounds of appearance of civil and civil procedural legal relations is that for the emergence of the first only the presence of a legal fact is required;

4) in the specific form in which the rights and respective obligations of the parties are expressed - civil and civil procedural legal relations are characterized by various forms in which the rights and obligations of the parties are expressed;

5) by the peculiarities of subjective law - the essence of subjective law of the side of civil legal relations is reduced to the right to one's own behavior, and civil procedural legal relations - to the right to demand a specific behavior from other persons;

6) by the nature of implementation - civil and civil procedural legal relations also differ significantly;

7) in accordance with the peculiarities of legal regulation - civil and civil procedural legal relations are characterized by both clear regulation of procedures and establishment of legal regulation of occurrence, change and termination of subjective rights;

8 ) in the period of existence - civil and civil procedural legal relations also differ, but insignificantly. In civil legal relations, time is set clearly or by reference to the term, or the occurrence of a certain event, which is associated with the termination of legal relations. In turn, for civil procedural legal relations is characterized mainly by legislative establishment of terms or references to the definition of terms in court decisions;

9) if necessary, the need for interaction between the parties - the need for interaction between the parties is characteristic of both civil and civil procedural legal relations. However, in both cases it takes different forms;

10) by property or non-property nature - both civil and civil procedural legal relations can be both property and non-property. It follows from the fact that such a nature is inherent in civil legal relations. As the civil-legal relations are actually a prerequisite for the existence of civil-procedural, we come to the conclusion that they can also be characterized by both varieties.

\section{CONCLUSIONS}

Thus, studying the ratio of civil law and civil procedural legal relations, we came to the conclusion that both types of legal relations are very close and closely interacting, although they are characterized by a number of significant differences. Initially, their interrelation can be characterized as bilateral, since the emergence of civil procedural legal relations is associated with the controversial nature of civil legal relations. In turn, the existence of civil procedural legal relations is a guarantee of ensuring the functioning of civil legal relations. Therefore, in general terms, these legal relations correlate as such that constantly and closely interact with each other. 
Analyzing and correlating separate elements of both types of legal relations, we have made a conclusion that civil and civil procedural legal relations essentially differ, especially in a part of a subject structure, object of legal regulation, on the bases of occurrence, forms of expression, features of subjective rights, character of realisation and so forth. It testifies to the fact that despite the proximity and a number of close ties, civil law and civil procedural legal relations are not subject to identification and coexist as two full-fledged and independent legal institutions.

\section{SUMMARY}

The article deals with the analysis of the relationship between civil and civil procedure. The categories of civil and civil procedural law, civil and civil procedural norms are compared, as well as the concepts of civil and civil procedural relations are established. The connection between civil and civil proceedings has been established.

The author examines the features that are sectoral criteria for the relationship between civil and civil proceedings. The author has established the ratio of civil and civil legal relations according to certain criteria. They should be divided into general and special ones.

The author emphasizes that by examining the relationship between civil and civil proceedings, we have come to the conclusion that both types of legal relationships are very close and closely interacting, although they are characterized by a number of significant differences.

\section{REFERENCES}

1. Цивільний кодекс України : Закон України від 16.01.2003 № 435-IV. Відомості Верховної Ради України. 2003. № 40. Ст. 356.

2. Протокол № 11, який передбачає перебудову контрольного механізму, створеного Конвенцією про захист прав і основних свобод людини : Міжнародний документ від 11.05.1994 № 11. Офіційний вісник Украӥни. 1998. № 13. Ст. 291.

3. Великий тлумачний словник сучасної української мови (з дод. і допов.) / уклад. і голов. ред. В. Т. Бусел. К.; Ірпінь : ВТФ “Перун”, 2005. $1728 \mathrm{c}$.

4. Голубєва Н. Ю. Співвідношення зобов'язальних та речових правовідносин . Часопис иивілістики. 2015. Вип. 19. С. 13-17.

5. Діденко Л. В. Співвідношення цивільно-правових та цивільнопроцесуальних відносин. Науковий вісник Ужгородського національного університету. Серія: Право. 2016. Вип. 41. Т. 4. С. 146-149.

6. Кілічава Т. М. Цивільне процесуальне право : навч. посіб. К. : Центр учбової літератури. 2007. 352 с. 
7. Мазур О. С. Цивільне право України : навч. пос. К.: Центр навчальної літератури, 2006. 384 с.

8. Підлубна О. В. Співвідношення норм цивільного процесуального права і цивільного процесуального правовідношення. Вісник Хмельницького інституту регіонального управління та права. 2002. № 2. C. 237-240.

9. Теоретичні проблеми цивільного процесуального права : підручник / М. М. Ясинок, М. П. Курило, О. В. Кіріяк, О. О. Кармаза, С. І. Запара та ін.; за заг. ред. д.ю.н. професора М. М. Ясинка. К. : Алерта, 2016. $890 \mathrm{c}$.

10. Тичинська Л. А. Правові засади цивільного процесуального права: співвідношення з іншими галузями права в умовах розбудови правової держави. Свропейські перспективи. 2014. № 4. С. 121-123.

11. Цивільне право : підручник : у 2 т. / В. І. Борисова (кер. авт. кол.), Л. М. Баранова, Т. І. Бєгова та ін. ; за ред. В. І. Борисової, І. В. СпасибоФатєєвої, В. Л. Яроцького. Х. : Право, 2011. Т. 1. 656 с.

12. Цивільний процес України : підруч. / В. О. Кучер та ін.; ред. В. О. Кучер. Львів : ЛьвДУВС, 2016. 768 с.

13. Штефан М. Й. Цивільне процесуальне право України : академічний курс. К. : Ін Юре, 2005. 624 с.

\section{Information about the author:} Didenko L. V., $\mathrm{PhD}$, Associate Professor at the Department of Civil and Economic Law and Procedure, International Humanitarian University 33, Fontanska Road str., Odessa, 65009, Ukraine 


\section{COMBATING CRIMINAL LAW COMPLICITY IN THE CRIME}

\section{Dombrovan N. V.}

\section{INTRODUCTION}

The proper criminal legal counteraction to the crimes committed by the accomplices depends to a large extent on the correct determination of the role of each of them in the commission of the crime, which is a necessary precondition for the punishment that would be appropriate to the nature and degree of participation of the accomplices in the crime. Unlike other accomplices (organizer, instigator, executor), the science of criminal law in Ukraine did not pay proper attention to the research of the legal evaluation of complicity.

The common law and practice approach is that this type of accomplice is considered the least socially dangerous among others. At the same time, the position of an accomplice in its content is to perform functions that generally make it possible to commit a crime by the executor and other accomplices. In doing so, this role of the accomplice is not limited solely to the physical or intellectual facilitation of the achievement of the common criminal purpose, but also to a certain extent contributes to strengthening the determination of other accomplices in the pursuit of the criminal intent.

Particularly important is the analysis of complicity a crime by a special subject, when the role of the accomplice is actually reduced to partial or complete fulfillment of the objective side of the crime, which, given the general principles of criminal law, does not receive a proper legal evaluation.

It should be noted that the objective complexity of socially dangerous acts committed in complicity, their multiple occurrences, the combination of different roles in the actions of one accomplice, necessitates the definition of clear criteria for differentiation of actions of different accomplices. In particular, this applies to the accomplice and the organizer (the latter may involve some form of assistance in committing the crime), the accomplice and the co-executor (the division of functions between co-executors may lead to one of them performing an auxiliary function), the co-worker and the instigator (the person inclining to committing the crime, and the person assisting it, influence the decision of the perpetrator to commit the crime).

Significant contribution to the study of criminal responsibility for complicity the crime was made by such scholars as: P. Andrushko, M. Bazhanov, A. Benitskyi, Yu. Bila, V. Glushkov, D. Gorbachev, N. Gutorova, A. Zakalyuk, O. Kvasha, O. Kostenko, O. Lytvak, M. Melnyk, 
A. Muzyka, V. Tatsiy, V. Tyhyi, M. Havroniuk, S. Hiliuk, S. Shapchenko, N. Yarmysh, S. Yatsenko and other scientists. Despite the considerable amount of research done by the institute on complicity in crime, many questions remain debatable and need further analysis, in particular to clarify the nature of complicity, distinguishing it from other accomplices, differentiating the criminal liability of an accomplice, and more.

Therefore, it is relevant and important to conduct a scientific study aimed at ensuring effective criminal and legal counteraction to complicity a crime.

\section{Genesis of complicity in the history of criminal legislation}

In the theory of criminal law was a common view, according to which the institution of complicity was completely identified with Art. 19 of the Criminal Code of Ukraine 1960 (the content of this provision is partially reproduced in Articles 26 and 27 of the current Criminal Code of Ukraine). So, speaking about the overall importance of the complicity institute, $\mathrm{N}$. Gutorova notes that the complicity institute extends its action to all cases of intentional joint committing of a crime, establishing objective and subjective indications of complicity, the limits of criminal liability of accomplices and peculiarities of assignment.

The institute of complicity in crime is one of the instruments of the state's implementation of criminal policy. Historically, its official function has been to justify the criminal responsibility of persons who did not commit the objective side of the crime themselves, but in various forms assisted it. Traditionally, in law, it was done through the identification of types of accomplices and the differentiation of their responsibilities.

Already in ancient sources of domestic criminal law we find mention of persons who assist in committing a crime - accomplices. However, despite the aforementioned obviousness of the content of the actions of the accomplice of the crime, both in theory and in law enforcement practice, there remain many issues related to their legal assessment.

Complicity was known for a long time, it did not require consolidation in the law, as it was obvious ${ }^{1}$. In the opinion of M. Kovaliova: "That is why no one and in the head came to specifically determine responsibility for the joint activity of several persons" ${ }^{2}$.

The first period of formation of complicity began in Rus. As P.Kolosovskyi rightly pointed out: "In Rus, much attention was paid to the

\footnotetext{
${ }^{1}$ Пипия А.Г. Ответственность за совместную преступную деятельность по римскому и западноевропейскому раннефеодальному праву. Правоведение. 1990. № 6. С. 91-96.

${ }^{2}$ Ковалев М. И. Соучастие в преступлении : в 2 т. - Свердловск : СЮИ, 1962. Т. 2. $274 \mathrm{c}$.
} 
mental activity of the perpetrator, not his actions" ${ }^{\text {. }}$. Thus, despite the fact that the Ruska Pravda did not contain the legal acts established by the criminalization of the accomplice of the crime, in general, they played an important role in establishing the institution of complicity. According to V. Momotov, this source is important not only in connection with the first mention in the history of domestic criminal law about complicity in the commission of a crime, but also sanctions. "For the sanction provided for in this article (Article 40 of the Short Edition of the Ruska Pravda) reflects the process of formation of criminal law itself as a public right, for which the sphere of social interest stands in the first place" 4 .

The second period in the formation of the Institute of complicity falls at the end of the fifteenth century and was related to the adoption of Sudebnyk 1497. This first codified legal act, like previous sources, did not contain the concept of complicity, its forms and types. However, Art. 19 provided for the release of boyars and scribes for complicity in wrongful accusation. It is also worth mentioning the Bilozerska diploma of 1539 , in which the concealers were clearly identified with the direct performers.

Sudebnyk 1550 already contained more rules governing complicity. The progressive vector of the development of this institute is evidenced by the securing of the special responsibility of guardians and indulgants towards all

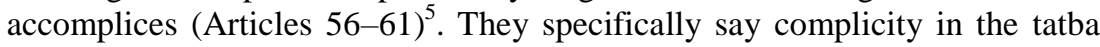
(abduction).

In the view of A.Pluzhnikova: The courts of 1497 and 1550 did not contain the established rules on complicity, as the basis of responsibility was the admission of guilt and people voice ${ }^{6}$. But as the spheres of criminal activity carried out in complicity, the increase in the number of such crimes, as well as the change in the number of participants in the crimes, there was a need to differentiate the responsibilities of the guards, the depositors and other accomplices. All this eventually led to the isolation of their species, which was consolidated in the Cathedral Code in 1649.

In the view of Ye.Epiphanova: "The conclusion, along with the interpretation of other legal institutions, gave a brilliant model of legislative

\footnotetext{
${ }^{3}$ Пипия А.Г. Ответственность за совместную преступную деятельность по римскому и западноевропейскому раннефеодальному праву. Правоведение. 1990. № 6. С. 91-96.

${ }^{4}$ Пипия А.Г. Ответственность за совместную преступную деятельность по римскому и западноевропейскому раннефеодальному праву. Правоведение. 1990. № 6. С. 91-96.

${ }^{5}$ Пипия А.Г. Ответственность за совместную преступную деятельность по римскому и западноевропейскому раннефеодальному праву. Правоведение. 1990. № 6. С. 91-96.

6 Плужников А.В. Соучастие в преступлении (проблема соучастия общего и специального субъекта): автореф. дис. на соискание науч. степени канд. юрид. наук : 12.00.08. Москва, 2008. 22 с.
} 
understanding of complicity"7 . In Art. 12 of Chapter X was for the first time a legislative system of types of accomplices, which was based on the selection of the main culprits (instigators and executors) and minor - assistants and patrons (accomplices). The main culprits were those who directly committed the crime (physically, the main culprits) or took action earlier than others from the very beginning of the crime. Participation is psychological, spiritual, such as advice, command, incitement, was also recognized. Assistants to the main perpetrators of the crime were usually called comrades. These persons contributed to the commission of the crime by unlawful acts or omissions, or delivered funds in advance for the commission of the crime or eliminated obstacles to the commission of the crime.

The third period of development of the principle of individualization of responsibility of accomplices is connected with the publication of the "order" of Katerina the Great in 1767. For the first time in the history of domestic criminal law "Order" quite clearly distinguished between the executor and other accomplices ("accessory") and demanded the establishment of different punishment them. At the base of this difference was the assessment of the contribution of each accomplice to the crime and correlated his responsibility. These provisions have been further developed. Thus, in 1833, the Criminal Code was put into effect, which made significant changes to the institution of complicity in crime. Thus, Section I of the First Book of Volume XV contained the norms of "Crimes" 8 . They distinguished the following categories of participants: a) associates who, in the aggregate, brought the crime into action, and invaders who acted together with others, but before their first put intent and consent to the others, or the former gave an example of committing the crime to others; b) assistants and participants, of which there were only six categories. The normative act also implemented the principle of individualization of punishment.

Institute of complicity in the middle of the XVII century - the beginning of XVIII century continued its progressive development in the norms of domestic criminal law. For the first time, the legislator establishes the general principle of liability for complicity as a joint, unbundled participation in a single unlawful act. More detailed consolidation was found in the legislation of Peter I and the provision of complicity, which was first considered as a complex system of alternative actions covering both intellectual and physical assistance to the perpetrator.

\footnotetext{
${ }^{7}$ Пипия А.Г. Ответственность за совместную преступную деятельность по римскому и западноевропейскому раннефеодальному праву. Правоведение. 1990. № 6. С. 91-96.

${ }^{8}$ Пипия А.Г. Ответственность за совместную преступную деятельность по римскому и западноевропейскому раннефеодальному праву. Правоведение. 1990. № 6. С. 91-96.
} 
The fourth period. However, the most detailed development of the Institute of complicity was carried out only until the middle of the XIX century. The decision to punish criminal and correctional officials in 1845 was the result of the codification of criminal law in the Russian Empire. In Art. 13-17 the Codification distinguished between two types of complicity: complicity without prior agreement (osprey) and complicity with prior agreement (conspiracy). The definitions of the main culprits and participants were summarized in Art. 14. And the notions of guards, sub-contractors, instigators and accomplices were stated in Art. 15. Article 12 of the Code lists the components of an accomplice's actions: direct assistance to the main perpetrators of the crime; delivery of means for committing a crime, removing obstacles. According to Art. 13 assistants were persons who, although not directly involved in the commission of the crime, but of selfish or other personal kinds, assisted or undertook to assist with advice or instructions and communications, or to supply any other means of committing the crime, or by removing obstacles, or knowingly, before committing a crime, sheltering themselves, or promising to assist in the concealment of criminals or crime ${ }^{9}$.

Thus, the authors of the Code sought to provide the most comprehensive list of acts constituting complicity of a crime. This approach should be considered justified from the point of view of law enforcement, since the legal assessment of complicity often raises the need to distinguish it from involvement in a crime. The formal approach to punishment of accomplices based on the objectively fulfilled role of each actor also implies from the same positions. The criminal conviction of 1903 not only significantly simplified the system of types of complicity, attributing to them the executor, instigator and accomplice, but also gave definition of complicity: "Acts committed by several persons who agreed to commit it or acted knowingly jointly".

Therefore, the main feature of complicity under the Criminal Code was the commonality of guilt. Art. 51 of the Code provides a list of participants, which include: a) the directly committed criminal act or persons who participated in its execution; b) inciting another to complicity in a criminal act; c) accomplices who have provided funds or assisted in the commission of a criminal act by advice, an indication or a promise not to obstruct it or to conceal it.

The assistants were persons involved in the crime itself, in terms of assistance in its execution. For complicity, it was important that there was a link between the accomplices and the perpetrators of the crime, proving an

\footnotetext{
${ }^{9}$ Пипия А.Г. Ответственность за совместную преступную деятельность по римскому и западноевропейскому раннефеодальному праву. Правоведение. 1990. № 6. С. 91-96.
} 
agreement to commit the intended crime. The accomplice always had to know that his actions would facilitate the commission of the crime.

Thus, the Criminal Code of 1903 gives a more concise definition of an accomplice, since the actions of its components displays information and the physical concealment of criminals. In addition, the Code introduced a fundamentally new approach to the responsibility of the accomplices of the crime. Thus, in particular, the instigator and the accomplice were punished when stipulated in the article of Code. If the assistance of an accomplice was not significant, then the punishment could be mitigated.

As a result of the historical and legal analysis of the rules on complicity in crime contained in the main monuments of domestic law, a number of conclusions emerge: despite the fact that the legislative definition of complicity was formulated only until the middle of the XIX century by Code, certain provisions on the types of accomplices, including the associate, were enshrined in early sources of domestic law (in the Belozerska diploma of 1539 and Sudebnyk 1550); the definition of complicity occurred against the background of delineating complicity from involvement in a crime; traditionally, in the sources of law throughout its development, the concept of an accomplice is revealed through the listing of his actions; in different periods of formation of criminal law, the content of the objective side of the assistance differs, it was most widely defined in Art. 12 and 13 of the Criminal and Correctional Code of 1845.

To summarize, we emphasize that the narrow understanding of complicity in the current criminal situation related to the increase of complicity crimes offered by the legislator in the Criminal Code of Ukraine does not correspond to the current criminal situation. An important role here is played by the limitations of criminal prevention against persons who intentionally contribute to criminal activity.

\section{Grounds of criminal liability of the accomplice from the position of criminal consistency theory}

The criminal liability of the accomplice for aiding and abetting the crime should be based on certain theoretical principles that would serve as a fundamental basis for addressing the issue of the social danger of this type of accomplice. This issue deserves special attention, both in the context of defining the principles of differentiation of legal consequences that occur in committing a crime in complicity with roles, and in the context of individualizing the punishment for their acts.

Such a fundamental basis is the theory of complicity, the scientific development of which was carried out by a number of domestic and foreign scientists to find out the legal nature of complicity, the place and role of each 
accomplice in the crime, the signs of causation in the actions of different types of accomplices. So, only the presence of complex, logical and consistent teaching can ensure proper criminal and legal response not only to typical but also atypical manifestations of intentional joint participation in committing a crime, for example, if the perpetrator does not finish the crime voluntarily refusing to commit other accomplices crime, excesses of executors (co-executors), etc ${ }^{10}$.

It should also be borne in mind that only through the general theory of complicity can the role of the accomplice be ascertained, which in turn must be reflected in the rules of criminal law and, in view of such a role, must the relevant law be applied in practice.

However, it should be noted that issues related to the concepts of complicity theory are some of the most difficult in criminal law theory and have not been resolved for a long time. Thus, scientists argue for different theories of complicity accessory (non-independent) or independent nature of complicity. Such a condition also causes inconsistent resolution of the question of the legal consequences of the accomplices for their socially dangerous acts and other consequences of behavior that has a criminal legal value. As V. Tkachenko, in the science of criminal law, there is probably not as much scientific work than those devoted to the Institute of complicity. However, we can say with confidence that it is the focus of many problems that have not yet been fully resolved: regarding the content of the notion of complicity, criteria for classification of its forms, grounds for liability of accomplices, etc ${ }^{11}$.

The question of the legal nature of complicity is linked to the general theory of criminal liability, which is based on fundamental principles, which obviously must be adhered to when dealing with the criminal liability of accomplices. In this context, it is necessary to cite F. Burchak's thesis, who argued that it is impossible to speak of the accomplice's responsibility for the actions of the executor without contradicting the basic ideas of criminal law and justice ${ }^{12}$. First of all, this thesis deals with the principle of personal responsibility, according to which a person is only responsible for the actions he or she has committed. F. Burchak's position is certainly grounded in the context of such types of accomplices as the organizer, instigator and accomplice who, according to their role in the criminal liability law, do not perform the objective side of the crime provided for in the Special Part of the Criminal Code of Ukraine.

${ }^{10}$ Кримінальне право України. Особлива частина : підручник/ за ред. В. В. Сташиса, В. Я. Тація. Вид. 4-е, переробл. і допов. Харків : Право, 2010. 608 с.

${ }^{11}$ Арутюнов А. Пособник преступления. Закон и право. 2002. № 11. С. 28-31.

12 Бурчак Ф.Г. Соучастие: социальные, криминологические и правовые проблемы. Киев : Вища школа, 1986. 208 с. 
Researchers analyzed within this section state that accessory theory of complicity first found its place. In the Criminal Code of France in 1791, and later in the Criminal Code of 1810. This concept was developed by representatives of the classical criminal law school. Initially, she assumed responsibility for another's crime, as some of her supporters adhered to the position of indeterminism and absolute freedom of will. The content of the accessory theory of complicity is revealed in the thesis that the social danger of the accomplice's actions directly depends on the nature of the performer's actions, which determines the accessory nature of the complicity ${ }^{13}$.

On the basis of the accessory theory of complicity in the science of criminal law, there are two main provisions: 1) the accomplice should be held liable only for the presence of signs of crime in the actions of the executor (it implies that the liability of the accomplice can only take place if the executor is prosecuted); 2) the accomplice is held liable under the norm of the criminal law, according to which the executor is prosecuted.

In particular, in the context of the validity of the accessory theory of complicity, I. Heifetz noted that the principle of division of labor, which is so conducive to the development of the economy, is very dangerous for society when used by thieves. Meanwhile, by destroying complicity and incriminating everyone with their own actions, the theory leads to a decrease in punishment in these cases ${ }^{14}$.

In turn, the theory of the autonomous nature of complicity is that each accomplice performs his or her own composition of the crime, and therefore the act of each is connected with another but independent crime ${ }^{15}$. The proponent of the same theory is A. Zelinskyi, who claimed that each accomplice was responsible for the acts they committed that contained the crime. Their responsibility is not derivative, but independent. In this sense, complicity is not accessory ${ }^{16}$.

In the context of the issues under study in this section, it is important to note that scholars point out that the role of the executor in matters of criminal liability of other accomplices is not exaggerated. As F. Burchak noted, the accomplices of the accomplished crime will only take place in the actions of

13 Кузнецов В.В., Савченко А.В. Теорія кваліфікації злочинів : підручник. Київ : Алерта, 2013. $320 \mathrm{c}$.

${ }_{14}$ Кримінальне право України. Особлива частина : підручник / за ред. В. В. Сташиса, В. Я. Тація. Вид. 4-е, переробл. і допов. Харків : Право, 2010. 608 с.

15 Плужников А.В. Соучастие в преступлении (проблема соучастия общего и специального субъекта): автореф. дис. на соискание науч. степени канд. юрид. наук : 12.00.08. Москва, 2008. 22 с.

${ }^{16}$ Кримінальне право. Загальна частина : підручник / за ред. А.С. Беніцького. Київ : Істина, 2011. $1112 \mathrm{c.}$ 
the accomplices if the perpetrator of the objective side of a particular crime is executed by the executor. In this and only in this sense, as noted by the scientist, the organizer, instigator and accomplice inherit the fate of the executor: the presence of a completed crime in the actions of the executor determines the composition of the completed crime in their actions, which, in turn, leads to criminal responsibility of the executor for the completed crime and his accomplices for organizational activity, inciting or aiding and abetting a crime ${ }^{17}$.

In addition to the assessment of the accessory and the theory of selfresponsibility of the accomplices, other theoretical concepts justified in explaining the legal nature of the complicity are justified in the science of criminal law. An example of such a concept is justified by D. Bezborodov is the idea of a joint criminal act, the essence of which is the commonality of encroachment on the interests protected by law. At the same time, the communion of action is conditioned by a certain combination of objective and subjective properties of the organization of actions (inaction) of several persons involved in committing a crime. Responsibility for committing a crime must be based on the following principles: first, the principle of inevitability of responsibility for each participant; secondly, on the principle of equal grounds of criminal responsibility for joint committing of a crime and for committing a crime by one person; thirdly, on the principle of independent responsibility of each participant of the action ${ }^{18}$.

At the same time, the scientific literature emphasizes that the theories analyzed cannot autonomously provide a systematic explanation of the legal nature of complicity or of various types of accomplices, and therefore cases where aspects from another are added to one or another theoretical basis. The same applies to the legal regulation of accomplices "liability in the Criminal Code of Ukraine, which contains rules that can be considered both based on the accessory theory of complicity and the theory of the independent nature of the accomplices" liability.

Thus, in particular, the research which was conducted by O. Kvasha allowed us to conclude that the rules governing certain aspects of the accomplices' responsibilities do not clearly reflect one theory of complicity. As an example of reflection of the theory of accessory, the scientist cites the provision according to which the accomplices (organizers, instigators, accomplices) are responsible for the crime committed by the executor

17 Бурчак Ф.Г. Соучастие: социальные, криминологические и правовые проблемы. Киев : Вища школа, 1986. 208 с.

18 Дядькин Д.С. Соучастие в преступлении: монография. Москва: Компания Спутник. 2004. 156 c. 
(co-executors), and their actions are qualified under the article of the Special Part of the Criminal Code, which is qualified by the actions, but with a mandatory reference to the relevant part of Art. 27. Also according to Part 4 of Art. 29 of the Criminal Code, in case of committing the perpetrator of the crime, the other accomplices are criminally responsible for complicity in the crime. In turn, provisions based on the opposite theory are the rules of legal evaluation of the voluntary refusal of the organizer, accomplice, instigator, as well as rules governing the legal consequences of the excess of the executor and according to which the accomplices are not criminally responsible for the act committed by the executor not covered by their intent (Part 5 of Article 29 of the Criminal Code) ${ }^{19}$.

Given the above, a rather widespread and well-grounded at the present stage seems to be a mixed position, which involves a combination of the two approaches analyzed, in other words, their symbiosis. In particular, this position is based on the claim that both points of view are opposed to each other in the literature, but these views have the right to coexist. They need not be contrasted ${ }^{20}$. The "mixed" theory of responsibility of the accomplices is substantiated by S.Avetisian, who states that the corresponding theory is caused by the fault of each of the accomplices, mixed actions in the process of planning the crime, as well as a mixed causal link between their actions and the damage that has occurred ${ }^{21}$.

Thus, we can conclude that the relevant provisions should also apply in determining the role and legal nature of complicity in a crime, the grounds of criminal liability of this type of accomplice. In particular, taking into account the value of the accessory theory of complicity gives an explanation of the grounds of criminal responsibility of a person who did not participate in the performance of the objective side of a certain act, but only facilitated its commission. In turn, the theories of self-responsibility of the accomplices make it impossible to find cases of "excessive" criminalization, which, in our opinion, would have occurred in the case of complicity in the crime, if it had not been completed, or in the case of criminalization an accomplice of actions not covered by his intent.

The significance of complicity theory is to explain what constitutes the criminal liability of the accomplice, in particular, given the fact that the actions of other accomplices do not contain the objective side of the composition of a

${ }^{19}$ Гуторова Н. А. Соучастие в преступлении по уголовному праву Украины: учеб. пособ. Харьков: ООО “Рубикон П”, 1997. 101 с.

20 Науково-практичний коментар Кримінального кодексу України/ за ред. О. М. Джужі, А. В. Савченка, В. В. Чернєя. Київ: Юрінком Інтер, 2018. 1104 с.

21 Аветисян С. С. Ответственность за подстрекательство и пособничество в преступлении со специальным составом. Закон и право. 2004. № 2. С. 37-39. 
particular crime and, therefore, there is no reason to claim the existence of a "classic" causal link between the actions of other accomplices and the consequences that have come from the direct actions of the perpetrator of the crime. V.Nawrockyi emphasizes that aiding, like any complicity in a crime, is an activity that is causally related to the activity of the perpetrator ${ }^{22}$.

The raised problem is that the criminal law of Ukraine is based on the philosophical postulate that a person can be held criminally responsible only for those negative changes in the objective world that were caused by the behavior of that person, that is, if there is a causal link between acts and socially dangerous consequences that have occurred ${ }^{23}$. That is why, in view of such a postulate, it can be argued that the grounds of criminal responsibility of an accomplice who provided the other person with the information necessary for committing a crime to the time of the stay of a person in a certain room, differ from the grounds of criminal responsibility of the executor, whose actions directly led to negative changes the objective world. Therefore, this postulate requires some clarification in the aspect of responsibility of the person, who facilitates the commission of a crime, whose actions do not directly lead to negative changes. Thus, the objective circumstances of specific socially dangerous acts involving other accomplices (organizer, instigator or accomplice) require special interpretation from the standpoint of the objective manifestation of their actions and the criminal result.

In view of the above, it should be noted that with respect to causation in the science of criminal law there is a position that, for all accomplices, a socially dangerous consequence resulting from the direct actions of the performer is causally related only to the act of the performer, whereas the actions of other accomplices are not by reasons, but only by the conditions of occurrence of the corresponding consequence ${ }^{24}$. The national scientist O. Kostenko distinguishes two cause-and-effect relationships when committing a socially dangerous act in complicity: 1) between the act of the organizer, the instigator, the accomplice and the onset of the state of readiness to commit a specific crime by the performer $(\mathrm{s}) ; 2)$ between the act of the executor (s) and the onset of criminal consequences provided for by the criminal law norm of the Special Part of the Criminal Code ${ }^{25}$.

${ }^{22}$ Навроцький В. О. Основи кримінально-правової кваліфікації: навч. посіб. Київ : Юрінком Інтер, 2006. 704 с.

${ }^{23}$ Вознюк А. А. Організовані форми співучасті за Кримінальним кодексом України. Науковий вісник національної академії внутрішніх справ. 2015. № 2. С. 97-106.

${ }^{24}$ Вечерова $€$. Співучасть як один із базових інститутів сучасного кримінального права. Право України. 2016. № 10. С. 170-176.

${ }^{25}$ Кузнєцов В.О., Гіжевський В.К. Кримінальне право України : навч. посіб. Київ : Кондор, 2008. 208 с. 
Scientist O. Kvasha states that causality in the structure of complex complicity has the following features: each accomplice's actions precede the onset; each accomplice contributes his or her own actions for the consequence (role distribution of causation); the activity of the performer depending on the previous or related activities of other accomplices; a criminal consequence is created by the joint, united actions of all participants in the crime. The actions of an individual accomplice, including the performer, cannot be considered in isolation from the complicity system, since in such a case they lose the properties of interconnection, interaction, and therefore the community, which is the essence of complicity as a system as a whole. At the same time, it is not necessary to over-generalize the participation of each of the accomplices and deprive them of their own (role) "contribution" to the criminal result. The actions of an accomplice cannot be "dissolved" in the concept of "common cause" when the role character of the actions of each of them cannot be distinguished. This does not meet the principles of criminal law of Ukraine ${ }^{26}$.

In the context of the above approach, we consider it prudent to draw attention to the thesis that the actions of an individual accomplice, including the performer, cannot be considered in isolation from the complicity system, since they in this case lose the properties of interconnection. The sign of integrativeness, for example, allows to find a legal explanation of the grounds of criminal liability of the accomplice in case if the perpetrator of the crime committed by him has used it.

Structure is defined as the internal base of the system, which is caused by the existence of stable connections between its parts (elements, subsystems) ${ }^{27}$, and the system is a complete integration of elements, which is based on a certain structure with a clear hierarchy of causation and interaction ${ }^{28}$. Traditionally, an accomplice is considered a lower link in such a structure, which is conditioned by the construction of Article 27 of the Criminal Code of Ukraine, and, as will be shown later, is enshrined in foreign criminal law. While the national scientist V. Nawrockyi is skeptical of this position. The scientist notes: "It indicates that when committing a crime, in complicity with the distribution of roles, may combine the performance of several such roles, in particular, the instigator and organizer, instigator and accomplice".

In general, it should be noted that this approach to understanding the essence of causation in crimes committed in complicity, also gives grounds to

${ }^{26}$ Кваша О. Актуальні проблеми розвитку інституту співучасті у злочині. Право України. 2014. № 5. С. 167-177.

27 Кримінальне право України. Загальна частина: підручник / за ред. В. Я. Тація, В. І. Борисова, В. І. Тютюгіна. Вид. 5-е, переробл. і допов. Харків : Право, 2015. 528 с

28 Вознюк А. А. Трансформація співучасті: поняття та форми. Боротьба 3 організованою злочинністю і корупиією (теорія і практика). 2014. № 1 (32). С. 68-71. 
conclude that neither the accessory theory nor the theory of the independent nature of the liability of the accomplices is not capable of purely provide the grounds of criminal liability accomplices.

From the perception of one or another theory of complicity depends largely on the approach to solve the question of the termination of the criminal act by each of the accomplices. In particular, the researcher of the questions of the law in time M. Bloom's conclusion is that according to the organizer, the time of committing the crime is the time of committing by other accomplices all the actions that led to the desired result, since he organized and managed the crime. For the instigator, the time of committing the crime is the moment when he inclined the perpetrator to commit the crime. For the accomplice, the time of the crime must be determined on the same principle. It follows that the organizer of the crime must be responsible under the law under which the perpetrator of the crime is responsible, and the instigator and accomplice under the law that acted during the commission of the acts that facilitated the commission of the crime ${ }^{29}$. We should agree with the above approach to the question of the law that should be applied to carry out a legal assessment of the accomplice's actions, since in our view the opposite approach would be contrary to the general principles of criminal law. At the same time, it should be noted that in such circumstances the rule under which the accomplice is liable under the relevant part of Article 27 and that Article (part of the Article) of the Special Part of the Criminal Code, which provides for a crime committed by the perpetrator, will not be fully implemented ${ }^{30}$.

Along with the discussion about the time of committing a crime, each of the accomplices also faces, the problem of finding out where they are committing the crime, especially in cases where the place of committing a crime influences the criminal law evaluation of a person's actions. In this context, M.Bloom states that: 1) the place of the perpetrator's act is decisive and must be recognized as the crime scene for the other accomplices (instigator, accomplice); 2) the place of actual commission by each of the accomplices stipulated by the agreement of actions (inaction) is the place of commission of the crime, regardless of the place where the crime was committed by the perpetrator; 3) the place of committing the crime of complicity is for all accomplices the place where the perpetrator committed the criminal acts, and for each accomplice there is also the place where they

${ }^{29}$ Кваша О. О. Співучасть у злочині: структура та відповідальність. Луганськ : РВВ ЛДУВС імені Е. О. Дідоренка, 2013. 560 с.

30 Науково-практичний коментар Кримінального кодексу України / за ред. М. І. Мельника, М. І. Хавронюка. Вид. 9-те, переробл. і допов. Київ : Юридична думка, 2012. $1316 \mathrm{c}$. 
were directly perpetrated by acts causally related to the actions of the perpetrator and contributing to the overall criminal intent ${ }^{31}$.

Thus, both the issue of the time of the crime and the place of its perpetration are related to the article of the Special Part of the Criminal Code, which establishes responsibility for a specific socially dangerous act. At the same time, the analysis of scientific works shows that the supporters of the accessory theory of complicity substantiate the position according to which the crime is described exclusively in the Special part of the Criminal Code, and therefore its commission cannot be charged to persons (organizer, instigator, accomplice) whose actions are absent.

However, the opposite position is justified in the science of criminal law. The composition of a crime is a system of attributes that is necessary and sufficient to recognize that a person has committed a crime and to prosecute it. The composition of the crime is an act determined by the criminal law, and not only the Special but also the General Part of it ${ }^{32}$.

We agree that it is inadmissible, at the present stage of the development of criminal law, to apply a simplified approach to the assessment of complicity only as the act of an executor, in addition to the actions of other accomplices. In order to ensure proper criminal-law protection of the order of public relations, such an approach to crimes committed not only by the perpetrators but also by other accomplices, should provide for a supplement to the Special Part of the Criminal Code of Ukraine, which would establish this type of responsibility also for the organizers, accomplices, instigators. An appropriate way of dealing with criminal liability has been implemented, for example, in the Kingdom of Norway, the General Part of the Criminal Code which does not contain the principles of complicity of the accomplices, instead, certain types of socially dangerous complicity are enshrined in the articles of the Special Part of this Code along with the main act perpetrated by the perpetrator. Obviously, in this context, one or the other approach to the construction of the law on criminal liability should be evaluated from the standpoint of the study of historical traditions and scientific views established in a particular country. Unlike the Norwegian, which is characterized by considerable casuisticity, the domestic Criminal Code contains mostly abstract formulations, which are not characterized by excessive detail and attachment to specific life situations.

${ }^{31}$ Кримінальне право України. Загальна частина : підручник / за ред. В. О. Меркулової, В. Я. Конопельського. Одеса : ОДУВС, 2017. 432 с.

32 Кваліфікація злочинів: навч. посіб. / за ред. О. О. Дудорова, Є. О. Письменського. Київ: Істина, 2010. 430 с. 
Thus, consideration of the basis of the criminal liability of the accomplice should be based not only on the assessment of the norms of the Special Part, but also on their inseparable connection with the norms of the General Part of the Criminal Code, which determines which of the ways of promoting the perpetration of socially dangerous acts are recognized as complicity is the basis for criminal offenses.

Among other things, the fact draws attention that scientists pay considerable attention to assessing the intent of the accomplices when determining the essence of complicity. Thus, in the context of the accessory theory of complicity, it is stated that the dependence of accomplices' liability on the responsibility of the performer can only be said in the sense that the performer realizes the criminal intentions of the accomplices, and if he fails to realize the criminal intent of the accomplices, to achieve the criminal result, then the responsibility of other accomplices as well as for the perpetrator, there is a preparation or attempted crime ${ }^{33}$.

In turn, in the aspect of the theory of the independent nature of the responsibility of the accomplices, the scientists state that although the criminal intent of all accomplices is embodied by the executor, they must all bear their own responsibility, since the activity of each accomplice has an independent value $^{34}$. The doctrine of complicity is based on the provisions of community of the intent of the accomplices, however, it is false that only the executor realizes the criminal intentions of the accomplices, since in many cases the accomplishment of the objective party by this accomplice would be impossible without fully accomplished roles by other accomplices: developing a plan, inclining to commit a crime, or making and providing tools for committing a crime, etc. Also, in this context, we consider it appropriate to pay attention to the provisions of the English criminal law doctrine that have established the "common criminal purpose" rule: one person is responsible for the other's actions to achieve the common criminal purpose for which they were united. This rule does not apply to actions that go beyond the scope of a joint venture. In other words, if the perpetrator deviates to a large extent from the assault in question and deliberately performs the other, then only he is criminally responsible for the crime. Another accomplice is responsible for the crime he actually committed ${ }^{35}$. Thus, the existence of legislative and

${ }^{33}$ Ткаченко В. І. Форма співучасті як кримінально-правове поняття. Вісник Київського національного університету ім. Тараса Шевченка. 2007. № 74-76. С. 144-146.

${ }^{34}$ Мельник М. І. Види співучасників за новим Кримінальним кодексом України. Право України. 2001. № 11. С. 69-74.

35 Уголовный кодекс Республики Беларусь : Закон Республики Беларусь от 09 июля 1999 г. № 275-3. URL: http://pravo.by/document/?guid=3871\&p0=hk9900275 (дата звернення 11.12.2019 p.) 
theoretical provisions regarding the consequences of the excess of the perpetrator make it possible to state the specific nature of the common intent to commit the crime, as well as to participate in its implementation or deviation from it in the commission of the crime.

However, it should be borne in mind that the role of the accomplice is reduced not only to the joint committing of the crime, which occurs in the form of assistance, but also in the promise to contribute to the concealment of the crime. In turn, the promise of contributing to the concealment of a crime may not have a strong causal link with the consequences of the act of complicity, and therefore, obviously, such activity has certain peculiarities. In this form of assistance, at least two options should be distinguished. The first is the case where the existence of such a promise causes or confirms the determination to commit the crime by other accomplices, that is, makes it possible to commit the crime. The second, in turn, envisages an exclusively auxiliary function whereby a socially dangerous act will be committed regardless of whether or not a particular person promises to contribute to the concealment of a crime. In our view, the analysis and resolution of this issue largely depends on determining the aspects of the role-sharing of the accomplices' responsibilities in each case, which should ultimately be reflected in the specific type and amount of punishment for the crime of complicity.

A detailed theoretical analysis of the grounds of criminal responsibility of the accomplices makes it possible to investigate the rules of the law of Ukraine on criminal liability, which regulate certain aspects of the legal assessment of the actions of the accomplice from the standpoint of the basis on which concepts the relevant rules are based. In particular, this applies to articles that determine the criminal liability of accomplices (Article 29 of the Criminal Code), criminal liability of organizers and participants of an organized group or criminal organization (Article 30 of the Criminal Code), as well as the voluntary refusal of accomplices to commit a crime (Article 30 of the Criminal Code) $)^{36}$.

Thus, the manifestations of the accessory theory of complicity in the part of the liability of the accomplice are as follows: the accomplice is liable for the relevant part of Article 27 and that Article (part of the Article) of the Special part of this Code, which provides for the crime committed by the perpetrator (Part 2 of Article 29 of the Criminal Code); in the case of committing the perpetrator of the crime, the accomplice is criminally responsible for complicity in the crime (part 4 of Article 29 of the Criminal

\footnotetext{
${ }^{36}$ Мельник М. І. Види співучасників за новим Кримінальним кодексом України. Право Украӥни. 2001. № 11. С. 69-74.
} 
Code); the accomplice, in the case of committing a crime within an organized group or criminal organization, shall be criminally responsible for the crimes in which he participated in the preparation or commission (part 2 of Article 30 of the Criminal Code).

In turn, the manifestations of the independent nature of the responsibilities of the accomplices in terms of liability of the accomplice are the following: the attributes that characterize the identity of an accomplice are to blame only to him, other circumstances, which make the liability, and provided in the article of the Special Part of this Code, as indications of an offense affecting the qualifications of the perpetrator's actions, are to blame for the accomplice if he was aware of these circumstances (Part 3 of Article 29 of the Criminal Code); the accomplice is not criminally liable for the act committed by the executor, if it was not covered by his (accomplice) intent (part 5 of Article 29 of the Criminal Code); in case of voluntary refusal to commit a crime, the executor (co-executor) shall not be held criminally liable for the conditions provided for in Article 17 of this Code. In this case, the accomplice is criminally responsible for preparing for the crime or attempting to commit the crime, which the perpetrator voluntarily refused to commit (part 1 of Article 31 of the Criminal Code); not be held criminally liable for voluntary refusal of an accomplice if he has prevented the commission of a crime or has informed in due time the relevant authorities of the state of a crime which is being prepared or committed. The voluntary refusal of the accomplice is also the failure to provide him with the means or the means of committing the crime or the elimination of obstacles to the commission of the crime (Part 2 of Article 31 of the Criminal Code) $)^{37}$.

Thus, according to the results of the conducted research, it can be concluded that the legal consequences of complicity in a crime stipulated in the law on criminal liability are based on a combination of two theories of complicity: the accessory and independent nature of the accomplices' liability. At the same time, the mixed approach maximally contributes to the proportionality of the means of criminal responsibility and socially dangerous participation of a person in the negative change of the order of relations between people established in the state.

\section{CONCLUSIONS}

As a result of the historical and legal analysis of the rules on accomplice in a crime contained in the main monuments of national law, it was established: 1) the legislative definition of complicity was formulated only until the middle

37 Фріс П. Л. Кримінальне право України. Загальна частина: підручник. Вид. 3-тє, переробл. і допов. Одеса : Фенікс, 2018. 394 с. 
of the XIX century by the Criminal and Correctional Penalty of 1845 ; 2) in different periods of formation of criminal law the content of the objective side of assistance is defined in Art. 12 and 13 of the Criminal and Correctional Penalty of $1845 ; 3$ ) the definition of complicity occurred against the background of delineating complicity from involvement in a crime; 4) the concept of complicity is revealed through the listing of his actions; 5) there is an unjustified refusal of the legislator to indicate the physical concealment, the previously not promised concealment, as well as criminal indulgence in the actions of the accomplice.

The legal consequences of complicity a crime envisaged in the Criminal Code of Ukraine are based on the combination of two theories of complicity: accessory and the theory of the accomplices' self-responsibility. In view of the above, we point out the expediency of changing the domestic approach to the legislative definition of the term "accomplice" in part 5 of Article 27 of the Criminal Code of Ukraine.

\section{SUMMARY}

The article investigates the theoretical principles of the criminal liability of the accomplice and their implementation in the norms of the Criminal Code of Ukraine. According to the results of the study, it is concluded that the legal consequences of complicity a crime under the criminal responsibility law are based on a combination of two theories of complicity: accessory and independent. It is stated that the approach to formulating the definition of "accomplice", by using an exhaustive list of appropriate actions, does not contribute to ensuring the proper criminal legal response to all the variety of actions of this accomplice in committing a crime. It is substantiated that in formulating the legislative definition of an accomplice, as a kind of accomplice, to indicate the specific ways by which socially dangerous assistance to the commission of a crime is carried out. The norms of the Criminal Code of Ukraine, which define the principles of liability of the accomplice from the standpoint of accessory theory and from the standpoint of independent complicity theory, are distinguished.

It is established that on the basis of the accessory theory of complicity in the science of criminal law are considered two basic provisions: 1) the accomplice should be held liable only for the presence of signs of crime in the actions of the perpetrator; 2) the accomplice is held liable under the norm of the criminal law under which the executor is prosecuted. It has been found out that the theory of the self-character of complicity is that each accomplice performs his or her own crime, and therefore each act is related to another, but independent crime. The theoretical concept of "The idea of joint criminal act" is analyzed, which stipulates the joint encroachment on the interests protected 
by law. The "Mixed" theory of the complicity of the accomplices, which is caused by the fault of each of the accomplices, mixed actions in the process of planning the crime, as well as a mixed causal link between their actions and the damage that has occurred is disclosed.

It is proved that the rules governing certain aspects of the accomplices' responsibilities do not clearly reflect one theory of complicity.

\section{REFERENCES}

1. Аветисян C.C. Ответственность за подстрекательство и пособничество в преступлении со специальным составом. Закон и право. 2004. № 2. C. 37-39.

2. Арутюнов А. Пособник преступления. Закон и право. 2002. № 11. C. $28-31$.

3. Бурчак Ф.Г. Соучастие: социальные, криминологические и правовые проблемы. Киев : Вища школа, 1986. 208 с.

4. Вечерова $\mathcal{C}$. Співучасть як один із базових інститутів сучасного кримінального права. Право Украӥни. 2016. № 10. С. 170-176.

5. Вознюк А.А. Організовані форми співучасті за Кримінальним кодексом України. Науковий вісник національної академії внутрішніх справ. 2015. № 2. С. 97-106.

6. Вознюк А.А. Трансформація співучасті: поняття та форми. Боротьба з організованою злочинністю і корупиією (теорія і практика). 2014. № 1 (32). C. 68-71.

7. Гуторова Н.А. Соучастие в преступлении по уголовному праву Украины: учеб. пособ. Харьков: ООО “Рубикон П”, 1997. 101 с.

8. Дядькин Д.С. Соучастие в преступлении: монография. Москва: Компания Спутник. 2004. 156 с.

9. Кваліфікація злочинів: навч. посіб. / за ред. О.О. Дудорова, Є.О. Письменського. Київ: Істина, 2010. 430 с.

10. Кваша О. Актуальні проблеми розвитку інституту співучасті у злочині. Право Украӥни. 2014. № 5. С. 167-177.

11. Кваша О.О. Співучасть у злочині: структура та відповідальність. Луганськ : РВВ ЛДУВС імені Е.О. Дідоренка, 2013. 560 с.

12. Ковалев М.И. Соучастие в преступлении : в 2 т. - Свердловск : СЮИ, 1962. Т. 2. 274 с.

13. Кримінальне право України. Загальна частина: підручник / за ред. В. Я. Тація, В.І. Борисова, В.І. Тютюгіна. Вид. 5-е, переробл. і допов. Харків : Право, 2015. 528 с.

14. Кримінальне право України. Загальна частина : підручник / за ред. В.О. Меркулової, В.Я. Конопельського. Одеса : ОДУВС, 2017. 432 с. 
15. Кримінальне право України. Особлива частина : підручник / за ред. В. В. Сташиса, В. Я. Тація. Вид. 4-е, переробл. і допов. Харків : Право, 2010. 608 с.

16. Кримінальне право. Загальна частина : підручник / за ред. А.С. Беніцького. Київ : Істина, 2011.1112 с.

17. Кузнецов В.В., Савченко А.В. Теорія кваліфікації злочинів : підручник. Київ : Алерта, 2013. 320 с.

18. Кузнєцов В.О., Гіжевський В.К. Кримінальне право України : навч. посіб. Київ : Кондор, 2008. 208 с.

19. Мельник М.I. Види співучасників за новим Кримінальним кодексом України. Право України. 2001. № 11. С. 69-74.

20. Навроцький В.О. Основи кримінально-правової кваліфікації: навч. посіб. Київ : Юрінком Інтер, 2006. 704 с.

21. Науково-практичний коментар Кримінального кодексу України / за ред. М.І. Мельника, М. І.Хавронюка. Вид. 9-те, переробл. і допов. Київ : Юридична думка, 2012. 1316 с.

22. Науково-практичний коментар Кримінального кодексу України / за ред. О.М. Джужі, А.В. Савченка, В.В. Чернєя. Київ: Юрінком Інтер, 2018. $1104 \mathrm{c}$.

23. Пипия А.Г. Ответственность за совместную преступную деятельность по римскому и западноевропейскому раннефеодальному праву. Правоведение. 1990. № 6. С. 91-96.

24. Плужников А.В. Соучастие в преступлении (проблема соучастия общего и специального субъекта): автореф. дис. на соискание науч. степени канд. юрид. наук : 12.00.08. Москва, 2008. 22 с.

25. Ткаченко В. І. Форма співучасті як кримінально-правове поняття. Вісник Київського національного університету ім. Тараса Шевченка. 2007. № 74-76. С. 144-146.

26. Уголовный кодекс Республики Беларусь : Закон Республики Беларусь от 09 июля 1999 г. № 275-3. URL: http://pravo.by/ document/?guid=3871\&p0=hk9900275 (дата звернення 11.12 .2019 p.)

27. Фріс П.Л. Кримінальне право України. Загальна частина: підручник. Вид. 3-тє, переробл. і допов. Одеса : Фенікс, 2018. 394 с.

\section{Information about the author: Dombrovan N. V.,}

$\mathrm{PhD}$ in Law, Head of Scientific Work Organization Department, Odesa State University of Internal Affairs 1, Uspenska str., Odessa, 65000, Ukraine 


\section{LEGAL STATUS OF THE CHIEF OF THE NATIONAL POLICE DEPARTMENT OF UKRAINE}

\section{Izbash K. S.}

The chief, as a person empowered with authority and who has some influence over subordinates, is a central figure in any team. A chief is a profession whose need arises when work becomes collective. He is the manager who must implement the management strategy, consolidate the efforts of his subordinates to solve important management tasks, while using his power. Unlike other categories of management staff, executives are a group of officials who are delegated rights and responsibilities of authority.

In accordance with the European standards and tasks of a legal democratic state and in the current conditions of reforming the system of the Ministry of Internal Affairs of Ukraine, the personnel of the bodies of the National Police, in particular, the leadership of these bodies, are of great importance. Today, the effectiveness of law enforcement agencies, including the National Police, in protecting the rights and freedoms of the individual and the citizen, combating crime and ensuring law and order in the country, is to develop new approaches and models for the formation of senior management, with due consideration for better international experience.

The urgent need and basis for the further development and improvement of the system of the National Police of our country is the quality and transparency of selection for senior police positions, professionalism and mastery of the chiefs of the newest forms of management of bodies and units of the National Police of Ukraine. The necessity and urgency of solving the problems of management of the bodies and units of the National Police of Ukraine impose strict requirements for their managers regarding their professional and personal qualities. Thus, research into the legal status of chiefs of bodies and units of the National Police of Ukraine, as well as the development of proposals for its improvement, are becoming increasingly relevant.

Problems of managerial activity of chiefs of bodies and divisions of the National Police of Ukraine have been the subject of research of many scientists, in particular: Bandurki O.M., Divak M.M., Kisil Z.R., Klochko A.M., Kovalyova M.V., Krischenko A.E., Kudri V.O., Matyukhina N.P., Petkova S.V., Plishkina V.M., Sokurenka V.V., Shatravy S.O., Yarmisch O.N. At the same time, despite the numerous conceptual approaches to solving it, the problem of staffing of the National 
Police of Ukraine remains open. Many important issues have not been resolved at all, including the role and importance of the chief in the activities of bodies and units of the National Police of Ukraine. However, significant shifts in the workforce of a number of post-Soviet states have been made possible by techniques tested in leading countries in the world.

\section{Theoretical approaches to definition of the chief, cadre and personnel}

The dynamic changes that have taken place in Ukrainian society in recent years, which is primarily related to the democratization of all areas of state activity, including law enforcement, require finding new approaches to reforming and staffing the National Police, including increasing the requirements for the professional activity of chiefs.

For a full study, first of all, one should refer to the definition of "chief". In the Great Interpretive Dictionary of Modern Ukrainian, the term "chief" is defined as "the one who controls someone, something, chiefs someone, something". In the Legal Encyclopedia, the term "chief" defines "an official who is vested with administrative authority over his or her collective and who manages it internally"2,3.

Professor Matiukhina N.P., in the terminology dictionary for personnel management of law-enforcement bodies of Ukraine, defines the chief of a person who is empowered to make managerial decisions and organize their implementation. It divides all chiefs into:

1) linear, who lead relatively separate systems and who not only coordinate the activities of subordinates and lower-level executives, but also make decisions regarding the strategy of system development, carry out the operational management of the entire activity of the system;

2) functional - chiefs of specialized services, departments and other units of all levels, whose responsibility is to prepare specific recommendations for line managers to make the latest decisions ${ }^{4}$.

For a full study of the concept of "chief", it would be advisable to study such categories as: "cadre" and "personnel", the definition of the content of which will help to characterize in more detail the category, which is outlined in the subject of our research.

\footnotetext{
${ }^{1}$ Великий тлумачний словник сучасної української мови / уклад. і гол. ред. В. Т. Бусел. Київ : ВТФ “Перун”, 2007. 1736 с.

2 Юридична енциклопедія / гол. редкол. Ю. С. Шемчушенко. Київ: Видавництво “Українська енциклопедія" імені М. П. Бажана, 2003. Т. 5. 733 с.

3 Юридичний словник / за ред. Б.М. Бабія, Ф.Г. Бурчака, В. М. Корецького, В. В. Цвєткова. Київ : Гол. ред. Укр. рад. енцикл., 1983. 872 с.

4 Термінологічний словник 3 управління персоналом органів внутрішніх справ України / Укладач Н. П. Матюхіна; за заг. ред. проф. О. М. Бандурки. Харків : Ун-т внутр. справ, 2000. 120 с.
} 
According to Academician Bandurka O.M. terms "cadre" and "personnel" are identical: "Cadre or personnel - is the main staff of the organization's employees who perform various organizational, technological and productioneconomic functions". Concerning the cadre of law-enforcement bodies, the scientist notes that they correspond to the following basic characteristics: they are persons who permanently or temporarily perform certain work functions in law-enforcement bodies (in their departments and institutions); performing such functions is foreseen by their main profession or specialty ${ }^{5}$.

In another aspect, the concept of "cadre" is considered by Plishkin V.M. according to which positions cadres of the Interior - a collection of individuals who serve as the primary occupation or profession regulatory official duties in the limits of regular number of organ or department of internal affairs and for receiving a reward in the form of salaries ${ }^{6}$.

Exploring the concept of "personnel", Pashkov O.S. notes that it brings together both "permanent" and "temporary" workers, representatives of both "qualified" and "unqualified" labor. He also emphasizes that, unlike personnel, they are full-time skilled workers who have previous professional training and have special knowledge, work skills or experience in their chosen field of activity ${ }^{7}$.

Describing the above concepts, we came to the conclusion that the concept of "personnel" in its content is much wider than the term "cadre"; cadre, according to the views of the majority of scientists, is a permanent staff of the organization, which occupies the positions envisaged by the staffing schedule, is responsible for their qualification characteristics to the job requirements and perform functions that require special professional training; personnel covers the notion of "cadre", as well as employees who work in the organization on a temporary basis, part-time or under a short-term employment contract. At the same time, the personnel include persons performing unqualified work that does not require special education or training.

The Disciplinary Statute of the National Police of Ukraine the term "chief" is also used, which means a police officer who is empowered to organize the official activities of subordinate police officers and other police officers and to control their official activities. In this legal act, executives are divided into direct, to which police officers are subordinate to the service, at least temporarily and directly. In turn, the nearest direct chief of subordinate is the subordinate's chief.

\footnotetext{
${ }^{5}$ Бандурка О. М. Управління в органах внутрішніх справ України: підручник. Харків : Унів. внутр. справ. 1998. 480 с.

${ }^{6}$ Плішкін В. М. Теорія управління органами внутрішніх справ : підручник / за ред.

Ю.Ф. Кравченка. Київ : Національна академія внутрішніх справ України. 1999. 702 с.

${ }^{7}$ Пашков О. С. Кадровая политика и право. Москва : Юрид. лит., 1989. 288 с.
} 
However, in the case of joint performance by police officers who are not subordinate to one another, the senior is considered to be a police officer designated by a direct supervisor or holding a senior position. If police officers occupy equal positions, the senior is determined by special rank $^{8}$.

The successful resolution of tasks assigned by the chief depends, first of all, on the personal qualities of the chief of the unit. As rightly points out Kulahin M.I., the chief "will be able to perform his functions successfully only if he presents a social model for his subordinates with his personal example and his behavior" ". We must also agree with the opinion of Selie H., who stated that "the choice of a place of work should start with the choice of a chief" ${ }^{\prime \prime}$.

As a result, it should be pointed out that the choice of the optimal variant of the managerial decision depends on the manager, the rational organization of work of the team, focused on the achievement of managerial goals. Managers are a kind of officials empowered by an administrative authority over a formally organized collective managed by them, who carry out internal organizational management of them.

The legal status of the chief of an organ or police department of Ukraine is enshrined in a number of normative documents: The Law of Ukraine "On the National Police of Ukraine", the Disciplinary Statute of the National Police of Ukraine, the Regulation on the Ministry of Internal Affairs of Ukraine; Order of the Ministry of Internal Affairs of Ukraine "On approval of the Rules of Ethical Conduct of Police".

According to the Law of Ukraine "On the National Police", the following managers of the system of the National Police of Ukraine are:

1) Minister of internal affairs;

2) the chief of the National Police of Ukraine;

3) chiefs of territorial bodies and units of the National Police of Ukraine $^{11}$.

Direct police leadership is exercised by the designated police chief who is assigned and dismissed by the Cabinet of Ministers of Ukraine upon the submission of the Prime Minister of Ukraine in accordance with the proposals

8 Дисциплінарний статут Національної поліції України : Закон України від 15 бер. 2018 p. № 2337-VIII. URL: https://zakon.rada.gov.ua/laws/show/2337-19 (дата звернення: 10.10.2019).

${ }^{9}$ Кулагин Н. И. Управление следственным аппаратом ОВД: автореф. дис. на здобуття наук. ступеня д-ра юрид. наук: 12.00.02. Москва : Акад. МВД Российской Федерации, 1990. $41 \mathrm{c}$.

${ }^{10}$ Бандурка О. М. Теорія і практика управління органами внутрішніх справ України : монографія. Харків : Основа, 2004. 780 с.

11 Про Національну поліцію: Закон України від 02 липн. 2015 р. № 580-VIII. URL: https://zakon.rada.gov.ua/laws/show/580-19 (дата звернення: 10.10.2019). 
of the Minister of Internal Affairs of Ukraine. The police chief has a first deputy and deputies, who are appointed to the post and dismissed by the Minister of Internal Affairs of Ukraine upon the submission of the Chief of Police.

A person may be appointed as the Chief and Deputy Chief of Police who: 1) meets the general conditions of entry into the police service; 2) has higher legal education; 3 ) has at least seven years of experience in the field of law; 4) Has at least five years of experience in management positions.

According to Art. 3 of the Disciplinary Statute of the National Police of Ukraine the chief is responsible for observing subordinate discipline and is obliged to: 1) create the conditions necessary for the performance of the police officer's subordinate duties; 2) respect the honor and dignity of subordinates, prevent violations of their rights and social guarantees; 3) develop a reasonable initiative and independence in the performance of duties as a police officer of subordinates; 4) to promote the development of subordinate level of qualification sufficient for the performance of official powers; 5) to study the individual and professional qualities of subordinates, ensuring transparency and objectivity in the assessment of their professional activity; 6) to ensure a favorable state of the moral and psychological climate in the team, to take timely actions to prevent the violation of official discipline of subordinates and the emergence of conflicts between them; 7) to control the observance of subordinate service discipline, to analyze its status and to report it objectively to the immediate supervisor, to carry out preventive work to strengthen the service discipline and to prevent the commission of subordinate offenses; 8) in case of violation of the subject of service discipline, take measures to end such violation and apply disciplinary punishment to the offender or initiate a request for the enforcement of the punishment by the authorized supervisor.

It should be emphasized that reforming the system of the Ministry of Internal Affairs of Ukraine, fulfilling the tasks envisaged by the Constitution and laws of Ukraine on protection of human rights and freedoms, combating crime, protection of public safety and order place new demands on the personal and professional qualities of the officers of the leading police force of the National Police of Ukraine cause the need to increase the value of their role in the police management system, the level of their managerial competence.

In this regard, the issue of qualitative and transparent selection of candidates for admission to the reserve of the leadership of the bodies of the National Police remains quite important. The main elements of this selection should be: an objective assessment of their personal and business 
qualities; training of reserve candidates; selection and appointment of the most suitable employees to the vacancies and analysis of their activities.

In addition, the chief of the police department should be clearly aware that his or her actions, behavior and activities depend to a large extent on the mental well-being of the subordinate staff and, therefore, his / her psychological health. The chief should act as an active subject of preserving the psychological health of his subordinates, for which he should have adequate psychological readiness for such activity, be a strong personality with a deep self-awareness, which manages his own emotional state and behavior. It is he who must be a balanced personality, able to successfully solve his personal problems and problems of the unit ${ }^{12}$.

In order to maintain the psychological health of the subordinate staff, the chief should be characterized by such traits as inner calmness, determination, openness, politeness, lack of fuss, flexibility of mind and consistency of behavior. At the same time, the chief should not be impulsive, irritable, irrepressible, aggressive, authoritarian, self-centered and self-interested ${ }^{13}$.

As Liaskovska O.A. notes, for effective management of people, a modern chief is obliged to have certain personal qualities that would give him the moral right to lead the team. These include: knowledge of job and function responsibilities; ability to choose methods for achievement of goals and increase of efficiency of functioning of organ; understanding the nature of management work and management processes; leadership capacity; the necessary skills in the management process of using modern means of communication; ability to perform special work in the management process of the National Police, etc. In the practical activity of the chief, such abilities are manifested in the ability to manage people and themselves, in the ability to teach and develop subordinates, the ability to understand people and form small groups, direct their activities; possess pedagogical techniques and skills, subtly and imperceptibly for the subordinates to teach them the task, bringing their professional qualification to the required standards ${ }^{14}$.

The chief of a body or unit of the National Police of Ukraine must, first of all, acquire a body of knowledge, skills and abilities that would enable: to

12 Конопльов В.В. Управлінські рішення в адміністративній діяльності органів внутрішніх справ: сутність та організаційно-правові питання підготовки і прийняття : монографія. Сімферополь : ХНУВС, ВДМВ “Таврія”, 2006. 356 с.

13 Барко В. І., Остапович В. П., Барко В. В. Вимоги до керівника як до суб’єкта збереження психологічного здоров'я поліцейських Національної поліції України. Право $i$ безпека. 2016. № 3 (62). С. 113-120.

14 Лясковська О. А. Керівник в органах і підрозділах Національної поліції України як організатор управління. Науковий вісник публічного та приватного права. 2017. № 3 . C. 114-118. URL: http://www.nvppp.in.ua/ vip/2017/3/24.pdf (дата звернення: 10.10.2019). 
ensure the functioning of the body or its structural unit in accordance with current conditions and requirements; to critically evaluate and predict economic, political, cultural and social events and phenomena; to understand modern problems of administrative activity and technology of administrative work; develop and implement new approaches and ideas; think analytically; be free to current legislation governing professional activity, as well as the proper filing of official documentation; combine fundamental knowledge with practice; use a modern methodology for the development, adoption and justification of management decisions, with mandatory consideration of universal values.

Thus, it is of utmost importance today that the National Police System of Ukraine has the most competent professional chiefs, capable of confirming the newest style of work and modern forms of management of the bodies and units of the National Police, and not just highly educated people with practical and life experience.

\section{Determination of the legal status and the role of the chief in the activities of the units of the National police of Ukraine}

The Law of Ukraine "On National Police" defines to a certain extent the legal status of such police posts as "police chief", "first deputy and deputy of police chief", "chiefs of territorial police bodies", "deputy chiefs of territorial police bodies", "police officers" who are the main categories of National Police officers.

There are different views among scholars on the category of "legal status" around which there is ongoing debate. To determine the legal status of a state body, Professor Komziuk A.T. considers it necessary to find out his place in the general system of executive power, the level and form of its legal regulation; to determine the limits of its competence, to determine the sphere of public relations regulated by this body, to list the objects, subordinate to it, to find out the range of tasks entrusted to it, the set of rights and responsibilities and its officials in the performance of the functions assigned to the body, that is, to determine the extent, possible behavior of the body and its officials in the performance of their functions (rights), as well as the extent of their mandatory behavior ${ }^{15}$.

According to the scientist Muzychuk O.M., determining the location and characteristics of the activities of any of the entities of legal relations is possible provided the analysis of their legal status and suggests under the legal

${ }^{15}$ Комзюк А. Т. Адміністративно-правові засоби здійснення митної справи : поняття та види. Вісник Харківського наџіонального університету внутрішніх справ. 2003. Вип. 22. URL: http://nbuv.gov.ua/UJRN/VKhnuvs_2003_22_41 (дата звернення: 10.10.2019). 
status of the entity of administrative and legal relations to understand the system of signs, which determine its role, place, enshrined in the legal acts. and appointments in the system of legal relations indicate its difference from other entities and the order of relations between them ${ }^{16}$.

The great legal dictionary defines that in Latin the term "status" means the position, status of something or anyone: "human status", "person status", "citizen status", "body status". Therefore, the term "status" applies to individuals and legal entities; this term is used by various industry sciences to study the structural elements of the subject of study of particular social relations ${ }^{17}$.

Concerning the definition of legal status, in the opinion of Volynky K.H., legal status is a system of interconnected rights and freedoms and responsibilities, which are enshrined in the law and determine the legal position of a person in society ${ }^{18}$.

According to Kravchuka M.V., the legal status of a person is the totality or system of all subjective legal rights, freedoms and duties, which determine the citizen's legal status in a society, which is enshrined in the current legislation and other forms of law ${ }^{19}$.

Therefore, legal status is a complex category, which contains complex structural elements, the main place among which is the rights and responsibilities of the subject (authority, competence).

Based on the analysis of the provisions of the Law of Ukraine "On the National Police", we believe that the legal status of the chief of units of the National Police is composed of the following elements: 1) the procedure for occupying the position of police chief; qualification requirements for the candidate (chief) for the respective position; 3) principles and guarantees of police service; 4) the authority and legal responsibility of the police chief; 5) grounds for dismissal from the position of police chief.

The decisive role of the chief of the National Police of Ukraine is that he is a decision-making authority. Having real power, the chief significantly influences his subordinates, and in general - the nature and results of the system. Skillful chief of the body clearly articulates the tasks of the staff, clearly understands their role in the process of their implementation, he is able

16 Музичук О. М. Уточнення сутності категорії “правовий статус” суб’єкта адміністративно-правових відносин та його елементного складу. Форум права. 2008. № 1 . C. 316-321.

${ }^{17}$ Большой юридический словарь / В. Н. Додонов и др.; под. ред. А. Я. Сухарева. Москва : Инфра-М, 1998. 790 с.

${ }^{18}$ Волинка К. Г. Теорія держави і права : навч. посіб. Київ : МАУП, 2003. 240 с.

${ }^{19}$ Кравчук М. В. Теорія держави та права. Проблеми теорії держави та права : навч. посіб. Вид. 3-те, змін. і доповнене. Тернопіль : Карт-бланш, 2002, 247 с. 
to find, identify and use the internal incentives of his subordinates and direct them to independent action, he is able to anticipate possible difficulties, prevent them from failure and find the best ways in each situation.

The chief of the National Police has a various but complementary functions. He also serves as an administrator, organizer, specialist, public figure and educator. In the activities of the chief of the National Police, these functions are implemented in such a close relationship that it is not always possible to distinguish how one function goes into another, but they are relatively independent ${ }^{20}$.

Bandurka O.M. points out rightly, "The activities of a modern chief are multifaceted. It combines the activities of defining the basic goals of the organization, as well as the ways to achieve them, the strategy of development: it is both influence on subordinates and performance of certain functions, both in relation to subordinates and the organization as a whole, and to other bodies". It follows that the daily activities of a chief can be reduced to performing such functions as: 1) administrative; 2) especially professional; 3) security; 4) educational; 5) control and supervision; 6) representative, etc ${ }^{21}$.

Practice management by the police demonstrates the need for timely and accurately recognize as the main chief, correct them see his ability to lead the team's future prospects.

The provisions of Art. 15 of the Law of Ukraine "On the National Police" defines the requirements that apply to the chief, the deputy chief of the territorial police body, namely: 1) meets the general conditions of entry into the police service; 2) has higher legal education; 3) has a minimum of five years of experience in the field of law; 4) Has at least one-year experience in management positions ${ }^{22}$.

According to Art. 21 of the Law of Ukraine "On the National Police", a person may be appointed as the chief and deputy chiefs of the police, who: 1) meets the general conditions for entering the police service; 2) has higher legal education; 3 ) has at least seven years of experience in the field of law; 4) has at least five years' experience in management positions.

The Ministry of Internal Affairs of Ukraine, with the purpose of forming in the police a sense of responsibility regarding observance of professional and ethical norms of behavior during the performance of official duties, as

${ }^{20}$ Дивак М. М. Шляхи вдосконалення форм управління якістю кадрового забезпечення Національної поліції в Україні. Вісник Харківського національного університету внутрішніх справ. 2012. № 1 (56). С. 175-181.

${ }^{21}$ Бандурка О. М. Теорія і практика управління органами внутрішніх справ України : монографія. Харків : Основа, 2004. 780 с.

22 Про Національну поліцію: Закон України від 02 липн. 2015 р. № 580-VIII. URL: https://zakon.rada.gov.ua/laws/show/580-19 (дата звернення: 10.10.2019). 
well as to promote strengthening of authority and trust of citizens to the National Police, the following orders were adopted, namely: "On approval Rules of Ethical Conduct of Police Officers" of 09.11.2016, No. 1179 and "On Approval of Rules of Ethical Conduct of the Employees of the Apparatus of the Ministry of Internal Affairs of Ukraine, Territorial Authorities, institutions and enterprises belonging to the Ministry of Internal Affairs" from 04.28.2016 267 p. 326237 number, which are in accordance with art. 37 of the Law of Ukraine "On Prevention of Corruption". These prescriptions are a generalized collection of professional and ethical requirements for police rules of conduct and are aimed at ensuring police service to the public by ensuring the protection of human rights and freedoms, combating crime, maintaining public safety and order on the basis of ethics and human values.

The chiefs of bodies of the National Police must comply with basic professional and ethical standards in their activities, which define the principles of ethics, which are: 1) honest service and loyalty to the state; securing state interests while performing the tasks and functions of the state; promoting the rights and legitimate interests of citizens and businesses; formation of a positive image of the state, including by changing the philosophy of business, where employees of the Ministry of Internal Affairs and the National Police are the center of security and guarantors of inviolability for law-abiding businessmen in conducting their business activities; 2) respect for the dignity of others; politeness and adherence to a high culture of communication; kindness and prevention of conflicts in relations with citizens; preventing, including out of work, actions and acts that may damage the work or adversely affect the reputation of the Interior Ministry and National Police; 3) focus on actions to protect public interests, prioritize the general good of the public over personal, private or corporate interests; inadmissibility of using state property for personal purposes; avoiding conflict between public and private interests; non-disclosure and non-use of information made known in connection with the fulfillment of the duties of the Ministry of Internal Affairs and National Police, including after the termination of its activity (except in cases prescribed by law); Preventing any benefits and showing affection for individuals and legal entities, political parties, public and religious organizations; 4) good faith in the implementation of decisions of the Verkhovna Rada of Ukraine, the President of Ukraine, the Cabinet of Ministers of Ukraine and state bodies in which the Ministry of Internal Affairs and National Police employees work, regardless of their own beliefs and political views; abstaining from any manifestations of public criticism of the activities of state bodies, their officials; correct attitude to the chiefs and employees of the state body in the performance of the duties of the Ministry of Internal Affairs and the National Police of their duties; 5) preventing the influence of political interests on the actions and decisions of the Ministry of Internal Affairs and National Police; refusal to publicly display political views 
and sympathies; compliance with the requirements for restrictions on political activity established by law for certain categories of police officers and the National Police; avoiding the use of symbolism by political parties in the performance of duties of the Ministry of Internal Affairs and of the National Police; ensuring transparency in relations with political actors; 6) openness and accessibility of information on the activities of the Ministry of Internal Affairs and National Police, except in cases specified by the Constitution and laws of Ukraine; 7) conscientious, honest and professional fulfillment of the duties of the Ministry of Internal Affairs and National Police, identification of initiative and creative abilities; constant improvement of the level of the professional competence and improvement of the organization of the activity; avoiding decision-making and responsibility for their actions and decisions.

The chief of police must meet the following general parameters: 1) knowledge of the legislation governing the activities of the National Police, knowledge and experience of working with regard to the specific authority, aspiration to improve their professional level, the ability to acquire knowledge independently; 2) psychological readiness for leadership, ability to make the most of the opportunities of subordinates, individual approach to subordinates, ability to distribute workload; 3 ) the ability to organize the work, the ability to really assess the situation, plan, implement the planned and exercise effective control; 4) mastering the skills of analyzing professional problems and tasks and finding ways to solve them, independent thinking, the ability to clearly, clearly and convincingly formulate their thoughts and ideas; 5) ability to communicate effectively with management, colleagues, subordinates and citizens, professional tact, mastering the basics of conflictology; 6) the ability to effectively and efficiently manage both in staff and in extreme situations, the ability to take on additional tasks in the case of urgent need, the willingness to make efforts to achieve a professional goal; 7) patriotism, self-criticism, honesty, self-esteem, culture of communication, tact, principle, impartiality, responsibility, desire to adhere to the norms of professional and professional ethics, etc.

One of the important areas of activity of the chief is the staffing of the police and the selection of candidates for enlistment in the reserve of the leadership of the National Police, the objective assessment of their business and personal qualities, the provision of training of candidates during their stay in the reserve, analysis of their activities and selection and appointment of the most suitable employees to the vacant positions ${ }^{23}$.

\footnotetext{
${ }^{23}$ Про затвердження Положення про порядок формування кадрового резерву на керівні посади в Міністерстві внутрішніх справ України, його територіальних органах та підрозділах: наказ Міністерства внутрішніх справ від 17 вер. 2012 р. № 808. URL: https://zakon.rada.gov.ua/laws/show/z1700-12 (дата звернення: 10.10.2019).
} 
The leading subject of personnel work in the bodies of the National Police is the Department of Personnel Assurance of the National Police, since it is the structural unit of the central government body of the National Police, which directly ensures the implementation of state policy on personnel and civil service in the staff of the National Police of Ukraine, territorial (interregional) bodies (establishments, institutions) of the National Police.

The main tasks of the Human Resources Department of the National Police in accordance with the current legislation of Ukraine are: staffing of police services; organizational, methodological and informational support of the work of police departments; ensuring the organization of work on the selection, study and staffing of police bodies with qualified personnel; the organization and methodological provision of special training for the first time recruited police officers in order to acquire the knowledge and skills necessary for the performance of police powers, as well as the training and retraining of police officers; organization of vocational training and internships, psychological support systems for police and National Police officers; ensuring that organizational and staffing activities are carried out by the National Police, optimal allocation and effective use of the existing staffing of the police to carry out the tasks and functions assigned to it; organization of work on strengthening of discipline and legality in activity of police officers, carrying out of service investigations, etc.

In connection with this, the leadership of the National Police of Ukraine is carrying out a number of organizational measures aimed at optimizing the structure and improving the quality of its personnel. Considerable work is reflected in forms of personnel management, among which there are general forms that are characteristic of all spheres of management, and special ones that can be found only in the field of research.

General forms include publication of regulations; publication of individual (legal, administrative) acts; implementation of other legally significant actions, organizational actions and logistical operations.

Special forms of personnel management include the following: a) identifying staffing needs (forecasting new jobs, scheduling staffing and quality staffing, selecting methods for calculating staffing requirements); b) career guidance with candidates for the service (analysis of sources of selection of personnel, selection of personnel, establishment of contacts with external organizations, business evaluation of personnel during selection) ${ }^{24}$.

In order to effectively manage people, a modern chief must have such personal qualities that would give him the moral right to lead the team ${ }^{25}$.

\footnotetext{
${ }^{24}$ Коруля І. В. Роль керівника у системі управління ОВС. Юридичний вісник. 2014. № 2. C. $63-68$.

25 Барко В. I. Професійний відбір кадрів до Національної поліції (психологічний аспект) : монографія. Київ : Ніка-Центр, 2002. 296 с.
} 
For example, the knowledge and ability to perform specialized work in the field of management of the National Police, which include an understanding of the nature of management work and management processes; knowledge of job and function responsibilities, ways to achieve goals and increase the effectiveness of the body; ability to use modern information technology and communication tools required in the management process; leadership skills. In the practical activity of the chief, these abilities are manifested in the ability to manage people and themselves, in the ability to educate and develop subordinates, the ability to understand people and form small groups, direct their activities; to have pedagogical techniques and skills subtly and unnoticeably for the subordinates to teach them the task, bringing their professional qualification to the required standards ${ }^{26}$.

Thus, the chief, influencing the subordinates, must be aimed at prompting them to certain service behavior that would meet both the requirements of the unit and his own ideas. Today, it is very important that management staff not only have highly educated people with life and practical experience, but competent employees who are able to confirm the modern style of work and to master the latest forms of management of police bodies and units.

The chief of the National Police must first of all possess a body of knowledge and skills that would enable: to provide the organ or its structural unit with the modern economic, political and social conditions and requirements; to combine knowledge of fundamental issues with practice, to have a modern methodology of substantiation of managerial decisions taking into account universal values, interests of the individual, society and the state; be free to navigate the legislation relating to the field of professional activity; critically evaluate and predict political, economic, social, cultural events and phenomena; to think analytically, to understand modern problems of management, technologies of administrative work, to produce new ideas, managerial decisions; to have the style of official documents and so on.

An important prerequisite for qualitative selection for managerial positions is the development and implementation of personnel management models of management activities of management personnel.

The model includes four components: 1) theoretical and methodological: knowledge of management theory and methodology; 2) practical: professional knowledge, interests and requests; setting and solving target settings; formation and improvement of intellectual, practical skills; creative orientation; self-regulation, self-improvement, self-education; 3) organizational: knowledge of methods and techniques of management; HR; application of the latest methods and technologies; software and information and

26 Барко В. І. Професійний відбір кадрів до Національної поліції (психологічний аспект) : монографія. Київ : Ніка-Центр, 2002. 296 с. 
communication support; innovative, experimental and scientific activity; 4) psychological: individual professional abilities; work and special experience; business, moral, ideological qualities; ideals; cultural norms.

The structure of the model has three main elements: the area of competence that underlies the managerial competence; the scope of the qualities that are necessary for the chief in each area, and the key characteristics of the chief's activities and behavior according to the qualification requirements. Using the model of managerial competence provides a methodological basis for identifying potential chiefs, developing training programs, drawing up plans for the professional development of executives, appointing the most suitable employees for a specific position. Also, a significant layer of competence of the chief of the National Police should be the authority on the organization of service in the National Police, since they allow to apply at the level with the methods of direct influence (orders, orders, etc.), and measures to encourage and encourage the National Police to properly perform their duties.

It is also necessary to mention the application of an administrative contract aimed at the effective resolution of managerial tasks to support discipline in the exercise of authority by the chief of the National Police, guarantee national and public order. Chiefs who regulate managerial relations through an administrative contract have to ensure that this goal is achieved, while maximizing their power over third parties while acting within their competence, fulfilling the tasks assigned to them. Accordingly, in the sole decision-making process, the chief of the body has the right to sign the contract, if it is expressly provided for by law or within its competence. In addition to the chief, the contract may be signed by an official who has been granted the right to sign by a special document (order, power of attorney, order, etc. $)^{27}$.

The systematic reform of law enforcement agencies in Ukraine in the direction of improving personnel work should be aimed at solving the following priority tasks: organization of work with personnel based on the use of the achievements of science, best domestic and foreign experience; implementation of measures for introducing contract and competitive recruitment of personnel to the National Police, improving the qualification requirements for candidates and employees, improving the efficiency of the system of professional and psychological training of staff; improvement of the normative base of personnel work, creation of

27 Тимчишин Т. М. Окремі аспекти використання адміністративного договору в регулюванні відносин державного управління. Науковий вісник Львівського державного університету внутрішніх справ. 2016. № 1. С. 217-225. 
an optimal system of scientific and methodological and informational support of work with personnel; improving the management of personnel processes on the basis of a modern system of scientific-analytical and information support; training of qualified and competent personnel for police units; realization of social rights and guarantees of employees; adjusting the number of employees in accordance with regulatory loads; creation of an effective mechanism of mutual responsibility of educational institutions and practical units for the quality of selection of candidates for training; scientific determination of the needs of the police in specialists of different specialties and specializations with standardization of state standards for their preparation.

Thus, police officers are referred to officials who, on a regular basis and within their powers, manage the bodies and units of the National Police, have a specific mission and a dedicated subordinate team, in which they carry out their management functions; are responsible to society for their activities; in the relations with the population are professional workers, direct representatives of the state power and holders of state-power powers.

To summarize, we would like to point out that we have offered the suggestions on the main areas of work of the chief of units of the National Police; requirements for their professional, organizational, managerial and moral-psychological qualities; the formation of a staff reserve, etc., if used, will help to improve the effectiveness of the management of units of the National Police as a whole.

\section{CONCLUSIONS}

We refer to police chiefs as officials who, on a regular basis and within their powers, manage the bodies and units of the National Police, have a specific mission and a dedicated subordinate team in which they carry out their managerial functions; are responsible to society for their activities; in the relations with the population are professional workers, direct representatives of the state power and holders of state-power powers.

The National Police System of Ukraine should have competent professional chiefs, capable of confirming the latest style of work and modern forms of management of bodies and units of the National Police, and not just highly educated people with practical and life experience.

Thus, suggestions we have offered above on the main areas of work of the chief of units of the National Police; requirements for their professional, organizational-managerial and moral-psychological qualities; the formation of a staff reserve, etc., if used, will help to improve the effectiveness of the management of units of the National Police as a whole. 


\section{SUMMARY}

The article is devoted to the study of the legal status of the chief of units of the National Police of Ukraine. Theoretical approaches to the definition and correlation of the terms "chief", "personnel" and "staff" are investigated. The concept of "legal status" is defined and the elements of "legal status" of the chief of units of the National Police of Ukraine are characterized. Requirements submitted to the chief of a territorial police body are analyzed. It is justified what criteria are put forward to the chief of the National Police. The main tasks of the Human Resources Department of the National Police in accordance with the current legislation of Ukraine have been clarified. General and special forms of personnel management in the bodies of the National Police of Ukraine are revealed.

\section{REFERENCES}

1. Дисциплінарний статут Національної поліції України : Закон України від 15 бер. 2018 р. № 2337-VIII. URL: https://zakon.rada.gov.ua/ laws/show/2337-19 (дата звернення: 10.10.2019).

2. Про Національну поліцію : Закон України від 02 липн. 2015 р. № 580-VIII. URL: https://zakon.rada.gov.ua/laws/show/580-19 (дата звернення: 10.10.2019).

3. Про затвердження Положення про порядок формування кадрового резерву на керівні посади в Міністерстві внутрішніх справ України, його територіальних органах та підрозділах : наказ Міністерства внутрішніх справ від 17 вер. 2012 р. № 808. URL: https://zakon.rada.gov.ua/laws/ show/z1700-12 (дата звернення: 10.10.2019).

4. Бандурка О. М. Теорія і практика управління органами внутрішніх справ України : монографія. Харків : Основа, 2004. 780 с.

5. Бандурка О.М. Управління в органах внутрішніх справ України: підручник. Харків : Унів. внутр. справ. 1998. 480с.

6. Барко В. І. Професійний відбір кадрів до Національної поліції (психологічний аспект) : монографія. Київ : Ніка-Центр, 2002. 296 с.

7. Барко В.І., Остапович В.П., Барко В.В. Вимоги до керівника як до суб'єкта збереження психологічного здоров'я поліцейських Національної поліції України. Право і безпека. 2016. № 3 (62). С. 113-120.

8. Большой юридический словарь / В.Н. Додонов и др.; под. ред. А.Я. Сухарева. Москва : Инфра-М, 1998. 790 с.

9. Великий тлумачний словник сучасної української мови / уклад. і гол. ред. В.Т. Бусел. Київ : ВТФ “Перун”, 2007. 1736 с.

10. Волинка К.Г. Теорія держави і права : навч. посіб. Київ : МАУП, 2003. $240 \mathrm{c}$. 
11.Дивак М.М. Шляхи вдосконалення форм управління якістю кадрового забезпечення Національної поліціївУкраїні. Вісник Харківського національного університету внутрішніх справ. 2012. № 1 (56). C. 175-181.

12. Комзюк А.Т. Адміністративно-правові засоби здійснення митної справи : поняття та види. Вісник Харківського національного університету внутрішніх справ. 2003. Вип. 22. URL: http://nbuv.gov.ua/UJRN/ VKhnuvs_2003_22_41 (дата звернення: 10.10.2019).

13. Конопльов В.В. Управлінські рішення в адміністративній діяльності органів внутрішніх справ: сутність та організаційно-правові питання підготовки і прийняття : монографія. Сімферополь : ХНУВС, ВДМВ “Таврія”, 2006. 356 с.

14. Коруля І. В. Роль керівника у системі управління ОВС. Юридичний вісник. 2014. № 2. С. 63-68.

15. Кравчук М.В. Теорія держави та права. Проблеми теорії держави та права : навч. посіб. Вид. 3-тє, змін. і доповнене. Тернопіль : Картбланш, 2002, $247 \mathrm{c.}$

16. Кулагин Н.И. Управление следственным аппаратом ОВД: автореф. дис. на здобуття наук. ступеня д-ра юрид. наук: 12.00.02. Москва : Акад. МВД Российской Федерации, 1990. 41 с.

17. Лясковська О.А. Керівник в органах і підрозділах Національної поліції України як організатор управління. Науковий вісник публічного та приватного права. 2017. № 3. С. 114-118. URL: http://www.nvppp.in.ua/vip/2017/3/24.pdf (дата звернення: 10.10.2019).

18. Музичук О.М. Уточнення сутності категорії "правовий статус" суб'єкта адміністративно-правових відносин та його елементного складу. Форум права. 2008. № 1. С. 316-321.

19. Пашков О.С. Кадровая политика и право. Москва : Юрид. лит., 1989. $288 \mathrm{c}$.

20.Плішкін В.М.Теорія управління органами внутрішніх справ : підручник / за ред. Ю.Ф. Кравченка. Київ : Національна академія внутрішніх справ України. 1999. 702 с.

21. Термінологічний словник 3 управління персоналом органів внутрішніх справ України / Укладач Н. П. Матюхіна; за заг. ред. проф. О.М.Бандурки. Харків : Ун-т внутр. справ, 2000. 120 с.

22. Тимчишин Т.М. Окремі аспекти використання адміністративного договору в регулюванні відносин державного управління. Науковий вісник Львівського державного університету внутрішніх справ. 2016. № 1. C. 217-225. 
23. Юридична енциклопедія / гол. редкол. Ю.С. Шемчушенко. Київ: Видавництво "Українська енциклопедія" імені М.П. Бажана, 2003. T. $5.733 \mathrm{c}$.

24. Юридичний словник / за ред. Б.М. Бабія, Ф.Г. Бурчака, В.М. Корецького, В.В. Цвєткова. Київ : Гол. ред. Укр. рад. енцикл., 1983. $872 \mathrm{c}$.

\section{Information about the author:}

Izbash K. S.,

Candidate of Law, Associate Professor,

Senior Researcher at the Department of Organization of Scientific Work,

Odessa State University of Internal Affairs 1, Uspenskaia str., Odesa, 65000, Ukraine 


\section{VOLUNTARY INSTRUMENTS IN THE SPHERE OF PRODUCTION IN EUROPEAN UNION LAW AND THEIR IMPORTANCE TO UKRAINE}

\section{Kachuriner V. L.}

\section{INTRODUCTION}

Environmental protection is one of the priority areas of the European Union's activities, which defines the EU's competence in the field of environmental protection and causes the adoption of a large number of panEuropean regulations. However, despite the considerable regulatory framework, there is insufficient attention in the EU legal system to legal regulation in the field of production and systematization of legal instruments of such regulation. The development of European environmental law is characterized by the search for optimal approaches to solving complex problems of natural resource management.

In the Association Agreement between Ukraine and the European Union, Article 360-366 of Section V, Economic and Sectoral Cooperation, is devoted to the environment itself. The Parties to the Agreement cooperate on environmental issues and thus contribute to the achievement of the goals of sustainable development and the "green economy". An analysis of European Union environmental legislation is essential to further improve and improve the effectiveness of Ukraine's environmental legislation. The priority of Ukraine's cooperation with the European Union will also be of practical importance - achieving the goal of improving the level of production productivity, expanding its economic growth base and competitiveness.

\section{Environmental agreements and environmental impact assessment as voluntary instruments in the sphere of production}

Developing a comprehensive production policy is a top priority for the European Union, given that positive EU action is aimed at identifying existing specific pollutants and protecting human health and improving the environment. As O. Dubovik rightly pointed out, there are currently several "approaches" and, accordingly, areas of legal regulation at EU level regarding the impact of production on the environment. These include: a) chemicals (most often this approach is manifested in the limitation of hazardous substances), b) hazardous waste management, hazardous substances and product "circulation", d) Commission recommendations on products used for energy production, e) the introduction of eco-labels, e) agreements in the field 
of ecology, g) integrated production and product management policies, c) resource management strategy, and) standardization ${ }^{1}$. In addition, O. Dubovik notes that the legal instruments of regulation in the sphere of production include: certification, setting standards and standards, environmental expertise ${ }^{2}$. But $T$. Rednikova offers several other legal instruments in the field of production: ecodesign, creation of ecological markets for dissemination of information by means of eco-labeling and product declarations, as well as sustainable consumption (in other words, making it environmentally friendly) ${ }^{3}$.

From the point of view of O. Trush, M. Andriyenko and G. Lomovsky, the European Union has introduced a range of environmental instruments: LIFE; environmental agreements; environmental duties and taxes; support programs for non-governmental organizations active in the field of environmental protection; Integrated product policy; The European Environment Agency; Eco-labeling of products; EU Eco-Management and Environmental Audit Scheme (EMAS); Environmental Impact Assessment (EIA) for certain public and private projects; assessment of the environmental impact of the implementation of plans and programs; environmental checks; European inventory of pollutants and transfers of pollutants ${ }^{4}$.

Considering the opinions of scientists, we propose to include the following voluntary instruments in the field of production in the law of the European Union:

1) environmental agreements: improving the environmental aspects of enterprise operations and implementing sustainable production methods through the promotion of voluntary measures and environmental agreements;

2) EU environmental management and environmental audit (EMAS) system: EMAS aims at ensuring continuous improvement of the environmental performance of European organizations, as well as providing relevant information to the public and stakeholders;

3) eco-labeling, which is focused on minimizing the negative environmental impacts of the main production or resource extraction, production of the products that are reflected in the standard. The marking process is usually called certification;

1 Дубовик О. Л. Экологическое право ЕС : формирование, развитие, достижения и актуальные задачи. Право и политика. 2004. № 12. С. 63.

${ }^{2}$ Дубовик О. Л. Международное право. М., 2003. С. 497.

${ }^{3}$ Редникова Т. В. Современные тенденции развития экологической политики в области производства продукции в Европейском Союзе. Политика и общество. 2006. № 6. С. 103.

${ }^{4}$ Труш О. О., Андрієнко М. В., Ломовських Г. А. Формування та реалізація спільної екологічної політики Свропейського Союзу в умовах сучасних інтеграційних процесів. Державне управління. 2014. № 1. URL: http://www.kbuapa.kharkov.ua/e-book/db/20141/doc/4/05.pdf 
4) Impact assessment can broadly be defined as assessing (predicting) the effects of current or anticipated action and assessing the environmental impact of plans and programs.

Let us analyze each of these tools. EU environmental policy instruments in the field of production should include instruments of a voluntary nature, such as voluntary agreements and "self-commitments", which have made many strides in the field in the last decade. It is possible that voluntary agreements have the chance to make manufacturers fully responsible, since targets are set directly on the basis of industry proposals. T. Rednikova in this regard noted that it can serve as a further motivation for the industry and mobilize its resources if the compliance of the industrial enterprise with its own requirements means trust in it ${ }^{5}$. Through voluntary agreements, changes in the production process can be implemented that will enhance environmental responsibility. As an example, Denmark has taken a significant step in this direction. In December 1996, the Danish Environmental Protection Agency formulated an Intensified, Product-Oriented, Environmental Initiative, which set out the following objectives: environmental (reducing the overall environmental impact of production, circulation and disposal); business objectives (increasing competition for the Danish business community by establishing the basis for the development, production and marketing of products with improved environmental performance); goals of organization of the process (involvement of all stakeholders in the implementation of environmental and commercial goals) ${ }^{6}$. As a result of such an initiative, as pointed out by T. Rednikova ${ }^{7}$, the negative impact of the production process on the environment was reduced.

It should be noted that environmental problems are not limited to the problem of polluting emissions from manufacturing plants, but are increasingly global. That is, the focus is not so much on the production process but on the environmental impact of the entire product life cycle.

Thus, if the Commission completes the analysis of the proposed environmental agreement, it may inform the European Parliament and the Council of its assessment and give its opinion on the recognition and approval of the agreement. After considering the comments received, in particular from the European Parliament and the Council, the Commission may decide to

\footnotetext{
${ }^{5}$ Редникова Т. В. Современные тенденции развития экологической политики в области производства продукции в Европейском Союзе. Политика и общество. 2006. № 6. С. 107.

6 Intensified Product Oriented Environmental Initiative. Copenhagen: Environmental Protection Agency, Ministry of Environment, 1996. P. 13-14.

${ }^{7}$ Редникова Т. В. Формирование и реализация интегрированной политики в области производства продукции в ЕС на национальном уровне на примере Дании. Право $u$ политика. 2009. № 12. С. 2467.
} 
recognize the environmental agreement. Information on such an environmental agreement is available, for example, on the commission's website, in order to give the general public an opportunity to be aware of the proposed Agreement and to comment ${ }^{8}$. Any recommendations for environmental agreements should be published in an official journal.

It is necessary to stimulate the preparation of voluntary environmental agreements at the Union level in various sectors of environmental legislation, but first of all, taking into account the scope of production, since today the reduction of production cannot be avoided, as, as D. Meadows correctly stated $^{9}$, mankind cannot abandon the traditional approach and is steadily increasing its industrial production by consuming natural resources. As this tool may not necessarily be the most appropriate in all circumstances, it is useful to identify a limited number of environmental policy areas where environmental agreements may provide additional benefits.

In the industry of EU Member States, "voluntary initiatives" are emerging to strengthen the environmental orientation of businesses and organizations. Yes, a number of companies have developed environmental and sustainable development policy principles. The Union of Entrepreneurs of the European Union have developed codes of conduct and recommendations for their members that contain environmental policy principles. The experience of developing such codes of conduct for industrialists and entrepreneurs is useful for our country as it is important for compliance with legal environmental requirements and organization of environmental activities of industrial enterprises in Ukraine.

The European Commission, while emphasizing the benefits of continuing to use "environmental agreements" capable of providing an effective and costeffective solution to the problems, has developed key criteria to be followed when concluding them. V. Kruglov states that environmental agreements have significant potential at the local level, because they allow to take into account the specifics of industrial production and on this basis to solve environmental problems of enterprises and territories related to, for example, water quality or restoration works after object closure ${ }^{10}$.

Regarding the environmental impact assessment (Impact assessment) in a broad sense, P. Modak defines it as an assessment (prediction) of the effects

${ }^{8}$ Communication from the Commission to the European Parliament, the Council, the Economic and Social Committee and the Committee of the Regions - Environmental Agreements at Community Level - Within the Framework of the Action Plan on the Simplification and Improvement of the Regulatory Environment / COM (2002) 412 final. P. 10.

${ }^{9}$ Политология : хрестоматия / Сост. М. А. Василик, М. С. Вершинин. М. : Гардарики, 2000. C. 786.

10 Круглов В. В. Законодательство Европейского Сообщества в сфере охраны окружающей среды в промышленности. Экологическое право. 2005. № 2. С. 46. 
of current or anticipated action ${ }^{11}$. Regarding the environmental impact of the implementation of plans and programs, it is undertaken to facilitate the integration of environmental aspects in the development stages of such plans and programs. The most significant types of assessments considered are: the Environmental Impact Assessment (EIA), the Strategic Environmental Assessment (SEA) and the Sustainability Impact Assessment (SIA).

Environmental Impact Assessment aims to identify and predict the expected environmental, health and well-being impact of people from economic and other activities. The EIA methodology has gained recognition in almost all developed countries. Adopted 25 years ago, Directive 85/337 of the EIA was to make use of the experience gained, to amend the laws and policies of the European Union and the case law of the European Court of Justice. According to her, as stated by V. Shevchuk, it is obligatory for the EU member states to conduct an EIA before issuing a permit for the implementation of all major projects that could have a negative impact on the environment ${ }^{12}$. The Directive was aimed at protecting the environment and quality of life by ensuring the approximation of national legislation to EU legislation, taking into account the environmental impact assessment of public and private projects. It is a key tool for integrating environmental issues across a wide range of projects and aiming to make them environmentally sustainable. The Directive harmonizes the EIA principles by introducing minimum requirements, in particular as to the type of objects to be evaluated, the main responsibilities of the developers, the content of the assessment and the involvement of the competent authorities and the public ${ }^{13}$.

On 26 October 2012, the Commission adopted a proposal for a new directive. This proposal seeks to simplify administrative barriers, which are largely unnecessary and to facilitate the assessment of potential impacts without weakening existing environmental safeguards. The quality of the decision-making process will be enhanced, the current level of environmental protection will be improved, and businesses should enjoy a more harmonized regulatory framework. Changes are also expected in areas such as resource

${ }^{11}$ Modak P., Biswas A. K. Introduction to EIA, What is EIA in : Conducting Environmental Impact Assessment for Developing Countries. Tokyo-New York-Paris : United Nations University Press, 1999. P. 12-14.

12 Шевчук В.Я. Екологічне управління : підручник. К.: Либідь, 2004. URL: http://pidruchniki.com/14860110/ekologiya/otsinka_vplivu_navkolishnye_seredovische.

${ }_{13}$ Report from the Commission to the Council, the European Parliament, the European Economic and Social Committee and the Committee of the Regions on the application and effectiveness of the EIA Directive (Directive 85/337/EEC, as amended by Directives 97/11/EC and 2003/35/EC) / COM (2009) 378 final. URL: http://eur-lex.europa.eu/procedure/EN/198470. 
efficiency, climate change, biodiversity and emergency prevention will now be reflected in the assessment process. In the process of further refining the environmental impact assessment, a new Directive $(2014 / 52 / E C)^{14}$ was adopted, which entered into force on 15 May 2014. First, it lowers administrative burden. Secondly, it increases the level of environmental protection, with the aim of making business decisions at public and private enterprises, which are the most predictable and sustainable in the long run. More attention is being paid to areas such as resource efficiency, climate change and disaster prevention. The main changes are as follows: States now have a mandate to simplify the various environmental assessment procedures; decisions must be duly motivated, taking into account updated selection criteria; EIA reports should be made clearer to the public, especially with regard to assessing the current state of the environment and making alternative proposals on issues raised; the quality and content of the reports will be improved; the competent authorities must also prove their objectivity in order to avoid conflicts of interest.

Directive 2001/42 / EC applies to a wide range of national plans and programs (e.g. land use, transport, energy, waste, agriculture, etc.) but is not relevant to policy ${ }^{15}$. Strategic Environmental Assessment (SEA) is mandatory for plans/programs that: prepare for agriculture, forestry, fisheries, energy, industry, transport, waste/water management, telecommunications, tourism, urban and rural planning or land use and, which set the basis for future development with the consent of the projects listed in the EIA Directive. The SEA procedures are limited to the preparation of an environmental report that identifies the likely significant environmental impact and possible alternatives to the proposed plan or program. The public and environmental authorities receive information and advice on the draft plan or program and prepare environmental reports. In the case of plans and programs which may have a significant environmental impact in another Member State, the Member State in whose territory the plan or program is being developed should consult with other Member States. The purpose of this tool is to monitor significant environmental impacts of the implementation of plans/programs in order to identify unintended negative impacts and take appropriate remedial action.

${ }^{14}$ Directive 2014/52/EU of the European Parliament and of the Council of 16 April 2014 amending Directive 2011/92/EU on the assessment of the effects of certain public and private projects on the environment Text with EEA relevance. Official Journal. 2014. L 124. P. 1-18.

${ }^{15}$ Directive 2001/42/EC of the European Parliament and of the Council of 27 June 2001 on the assessment of the effects of certain plans and programmes on the environment. Official Journal. 2001. L 197. P. 32. 


\section{The legal basis for EMAS and eco-labeling in the sphere of production}

In 1993, the EU introduced a system of voluntary participation of industrial enterprises in environmental audit, which in 2001 became open to other organizational forms - administrations, consumer care institutions, etc. ${ }^{16}$. Directive 2001/42/EC on the assessment of the effects of individual plans and programs on the environment ${ }^{17}$ was adopted in order to harmonize a number of general provisions on the environmental impact assessment of development plans and programs developed in the field of agriculture, fisheries, forestry, energy, transport, water management, telecommunications, tourism, pollution control, urban and rural planning. Particular attention is paid to Directive 2001/42/EC in evaluating programs and plans capable of transboundary environmental impacts within the EU. The decision to carry out their assessment shall be taken on the basis of consultations between Member States. However, the system of environmental management, while emphasizing O. Bilyk, did not meet modern requirements, so it needed a qualitative restructuring of economic instruments of environmental regulation, the development of an effective economic mechanism of environmental protection activities, one of the main elements of which is an effective system of environmental management of industrial enterprises ${ }^{18}$.

Sponsor voluntary commitments are still rare in the environmental field. Most often, they offer financial assistance to avoid legal obligations. L. Kremer and G. Winter state that the exceptions are the obligations of the automobile industry, which reduce $\mathrm{CO} 2$ emissions in new cars, and the provisions on the use of detergents have become of some importance. Quite often, the degree of integration of organizations in Europe is insufficient to achieve a balanced, large-scale, substantial material commitment.

The legal basis for the functioning of the environmental management and audit system within the European Union is Regulation 761/2001, which establishes the conditions for the registration of objects by the organization, the requirements for environmental policies, programs and systems, the criteria for environmental audit and environmental audit procedures, as well

${ }^{16}$ Кремер Л., Винтер Г. Экологическое право и политика Европейского Союза : законодательные основы, реализация, судебная практика. Политика и общество. 2006. № 6. C. 55.

${ }^{17}$ Directive 2001/42/EC of the European Parliament and of the Council of 27 June 2001 on the assessment of the effects of certain plans and programmes on the environment. Official Journal. 2001. L 197. P. 30.

${ }^{18}$ Білик О. С. Екологічний менеджмент на промислових підприємствах України: зміст та сутність поняття. Экологический менеджмент. 2012. № 12. С. 49. 
as introduces requirements for environmental auditors and eco-auditors ${ }^{19}$. It has been adopted to assist businesses and organizations and aims to improve corporate governance, creating common technical standards for environmental policies for businesses operating in the European Union. At the same time, Regulation 761/2001 contributes to strengthening the compliance of companies with environmental requirements by Member States and the EU.

In 2009, the Council of Europe and the European Parliament adopted at first reading the decision to reform two key EU instruments in the area of sustainable consumption and production management - Ecolabel and the Environmental Management and Audit System (EMAS). Both schemes will continue to be voluntary.

Due to the multilingualism in the EU, it is necessary to develop symbols that inform the user without additional linguistic information about positive or negative qualities. No political system has so far been able to develop such a system of symbols. Eco-labeling is a voluntary program designed to motivate producers of goods and services. The goal is to promote products with reduced environmental impact (compared to other products in the same group), to make consumers more loyal to nature and European consumers, and to make them more recognizable as environmentally friendly products ${ }^{20}$. This program is the result of various national initiatives such as "Der blaue Engel" (Germany), "Milieukeur" (Netherlands) or "White Swann" (Scandinavian

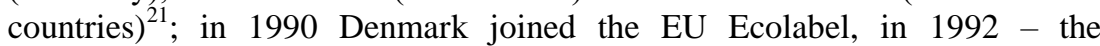
introduction of the European Flower label in Denmark ${ }^{22}$, in 1997 - Denmark joined the Scandinavian Liberty labeling system ${ }^{23}$.

Industrial products are increasingly the result of processes involving several large and small companies at the same time. Today, consumers need quality, innovative products that are environmentally friendly and of a higher quality. In this context, the isolationist competitive strategy is losing its

${ }^{19}$ Directive 2000/60/EC of the European Parliament and of the Council of 23 October 2000 establishing a framework for Community action in the field of water policy. Official Journal. 2000. L 327. P. 10.

${ }^{20}$ European Commission, 2006b. European Commission, Environment, Eco-label. URL: http://ec.europa.eu/environment/ecolabel/index_en.htm.

21 Мельник Л. Г., Дегтярьова І.Б. Європейський досвід використання економікоправових інструментів забезпечення сталого розвитку. Механізм регулювання економіки. Суми. 2012. № 1. С. 20.

${ }^{22}$ Eritja Mar Campins. European Community Eco-Labeling Scheme / Ed. by Prof. Richard. Macrory. Reflections on 30 Years of EU Environmental Law. Groningen: Europa Law Publishing, 2006. P. 109-128.

${ }^{23}$ Редникова Т. В. Формирование и реализация интегрированной политики в области производства продукции в ЕС на национальном уровне на примере Дании. Право $u$ политика. 2009. № 12. С. 2466. 
relevance. Companies and organizations are forced to work together to be able to maneuver revenues from different sources, diversify and create quality products and services. Systematic quality management is one of the important innovations of the 21st century. Quality is a concept because it combines accurate approaches, pricing aspects, meeting needs and informing consumers.

An innovative strategy to ensure the harmonization of society and the environment envisages the improvement of standardization and certification systems, their harmonization with the requirements of European legislation and regulations. According to L. Melnik, the production of environmental goods and services is a highly profitable area of economic activity, forming production that is much more gentle to the environment. Indicators of ecological excellence of products for the future should take into account packaging, which can characterize eco-degradation in the previous stages of packaging production ${ }^{24}$, where the author does not specify the meaning and function of eco-labeling.

P. Skripchuk concludes that greening the economy with the help of existing economic instruments of environmental policy on the information system of the economic sphere does not include labeling of goods, including environmental as informing the population about possible environmental damage and insufficient use of certification of quality management systems by (ISO 9000), Environmental Management Systems (ISO 14000), Life Safety (OHSAS 18001), Risk Analysis and Critical Control Point, Environmental Audit Procedures in (ISO 19011), environmental certification and many products especially food groups ${ }^{25}$.

The overall purpose of eco-labeling is to convey to consumers the information on the environmental impact of products and, on the contrary, the environment on products throughout their life cycle. One of the benefits of eco-labeled products is that they are thus identified, collected and recycled. The environmental benefits of an eco-friendly economy in many countries are well-researched and best proven in Germany (activities of associations, recyclers and recyclers, life cycle analysis of packaging or packaging, responsibility for collection of packaging in the middle of an association, etc.). packaging and packaging actually rotate into one corporation (for example, in Germany, DSD - an association of collection, processing and packaging companies that have the green marking of the "Green Dot". Other

${ }^{24}$ Мельник Л. Г. Екологічна економіка : Підручник. Суми : Університетська книга, 2002. C. 140.

25 Скрипчук П. М. Екологічне маркування: інноваційні та організаційні аспекти. Механізм регулювання економіки. № 1. 2007. С. 104-105. 
sources indicate high levels of management and environmental benefits to EU countries of using secondary packaging materials ${ }^{26}$.

An interesting report by Professor Mar Cainpins from the University of Barcelona on eco-labeling issues. This topic is especially important for the protection of consumer rights and is of interest in the field of UkrainianEuropean export-import operations. It has been noted that eco-labeling is becoming more and more important, and this is reflected in various EU programs, for example, Euro-Flower, approved by EU Decree 1980/2000 ${ }^{27}$. This program is one of the most extensive schemes in the field of legal regulation. However, there are many different kinds of endeavors that characterize different systems from different sides in different spheres, including deviations from common approaches. A key change for the EU is to address the problem of determining the place for the EU member state and thereby mediating the EU eco-labeling system and avoiding that systems that deviate from the single rule may cause barriers to the EU's internal market to increase, as well as in North-South relations. In conclusion, prof. M. Campins concluded that for successful influence on the market it is necessary to involve the society in this problem, consistency with the international character and influence of trade on developing countries ${ }^{28}$.

The voluntary nature of the Ecolabel scheme means that it does not create a barrier to market and trade, but rather gives manufacturers a competitive advantage. The Ecolabel criteria are not based on one factor, use different studies, analyze the impact of products or services on the environment throughout its life cycle, from raw material production to production, distribution and disposal. In other words, the Ecolabel European Union logo helps manufacturers and suppliers of goods and services to be recognized for high standards.

Ecolabel is part of a broader Action Plan on Sustainable Consumption and Production and Sustainable Industrial Policy, adopted by the Commission in 2008, which contains a number of key recommendations for the development and implementation of a pan-European criterion for environmentally responsible public procurement. The process of developing such a criterion at the pan-European level should take into account all existing developments in establishing an environmental criterion within the framework of sustainable production and consumption, based on the life cycle of the product or service. Examples of potential sources of such a criterion are: Energy Star energy efficiency requirements for office equipment, environmental performance

\footnotetext{
${ }^{26}$ Web-site Consumers Internationals. URL: www.consumersinter national.org/word

${ }^{27}$ Regulation (EC) № 1980/2000 of the European Parliament and of the Council of 17 July 2000 on a revised Community eco-label award scheme. Official Journal. 2000. L 237. P. 1-12.

28 Дубовик О. Л. Экологическое право ЕС : формирование, развитие, достижения и актуальные задачи. Право и политика. 2004. № 12. С. 62.
} 
criteria that will be developed in the course of implementing measures under, for example, the provisions of the Directive on the promotion of environmentally friendly and energy efficient vehicles ${ }^{29}$.

The basic principles of eco-certification are: control of the production process, not the final product; field-to-counter control, ie all stages from creation to sale to the final consumer (production, processing, sale, including importers and exporters); independence and impartiality of the certification body. Enterprises, ie manufacturers, processors, sellers, importers and exporters wishing to label their products as "environmentally friendly", "organic", "eco", "bio", etc., must undergo annual inspection and certification. The revised Ecolabel scheme simplifies the requirements for participants and focuses more on products and services that have the most significant environmental impact. During the revision of the Ecolabel provisions, the amount of the mandatory contributions was also reduced. At the end of 2009, almost 20,000 goods and services manufactured and provided in the EU were awarded the Ecolabel $\log _{0}{ }^{30}$. T. Rednikova cites such an example when, in the late 1980s, Denmark's environmental policy shifted to creating environmentally friendly "clean" production technologies. The focus was on conducting experiments to identify environmental problems in various industries and to develop demonstration projects for technical solutions to these problems within individual industrial enterprises. The disadvantage of such a program was to focus on the production process instead of exploring the entire product life cycle. Subsequently, the country paid attention to environmental management and cooperation projects between different enterprises and municipal authorities in the field of environmental protection - introduced environmental labeling of products, i.e. production and turnover issues are introduced into the common understanding of clean technologies. The introduction of clean production processes at industrial plants leads to a reduction of environmental pollution and reveals the link between environmental certification and environmental pollution control. As M. Andersen rightly pointed out, flexible environmental policies should encourage industry to introduce new forms of production and create products that are more environmentally friendly and environmentally friendly ${ }^{31}$.

${ }^{29}$ Directive 2009/33/EC of the European Parliament and of the Council of 23 April 2009 on the promotion of clean and energy-efficient road transport vehicles (Text with EEA relevance). Official Journal. 2009. L 120. P. 5.

${ }^{30}$ Directive 2009/125/EC of the European Parliament and of the Council of 21 October 2009 establishing a framework for the setting of ecodesign requirements for energy-related products. Official Journal. 2009. L 285. P. 10.

${ }^{31}$ Andersen M.S., Jorgensen U. Evaluation of Cleaner Technology Programme 1987-1992 : Results, Diffusion and Future Activities. Copenhagen : Environmental Review, 1995. № 14. 
The major changes in the EMAS scheme concerned the needs of small and medium-sized enterprises ${ }^{32}$. Innovations aimed at adopting a sectoral approach to implementing best practices in environmental management, extending EMAS beyond EU countries, and increasing monitoring of environmental compliance and developing environmental reporting systems.

The drafters believe that this should increase the number of companies participating in the Ecolabel and EMAS programs, as well as reduce the administrative pressure and costs of EU small and medium-sized enterprises ${ }^{33}$. An organization can be represented in this system or by one enterprise, or by several or even all enterprises. It has defined environmental policy and has committed itself to adhere to the relevant regulations to improve its environmental performance. The company controls the consumption of water, energy and emissions. The organization establishes a program to achieve its environmental policy goals and subject itself to internal and external audit to monitor compliance with environmental legal requirements. At the end of the progress or desired progress, this message is also checked. As a reward, an organization may indicate its affiliation with the Environmental Management and Environmental Audit system in business papers and documents, but not on products, packaging or product advertising.

For Ukraine the formation of an integrated system of environmental management in industrial enterprises is an effective tool for complex solution of the task of ensuring the quality of products, environmental protection, professional safety of production and responsibility of the enterprise to society and promoting the integration of Ukraine into the world community. The current ecological situation and trends of its change are largely determined by industrial production and economic activity in general.

Ukraine has officially joined the international community in the field of implementation and development of environmental management ${ }^{34}$. The quality of products or services is one of the most important factors in the success of any production activity. It is a set of properties and characteristics of products or services that give them the ability to meet the stipulated or foreseen needs of a modern person. O. Bilyk emphasizes that nowadays the demands of the consumer for the quality of products have considerably

32 Бут Ю.С. Управління процесами використання природних ресурсів в країнах Європейського Союзу: екологічний аспект. Виртуальная библиографическая справка. Объединенная справочная служба библиотек Украины. URL: http://www.nbuv.gov.ua/ e-journals/PSPE/2011_2/But_211.htm

${ }^{33}$ From Conflict to Peacebuilding: The Role of Natural Resources and the Environment, UNEP 2009. URL: http://www.unep.org/pdf/pcdmb_policy_01.pdf.

34 Потай О.А. Формування інтегрованої системи екологічного менеджменту промислових підприємств. Науковий вісник НЛГУ. 2009. Вип. 19.9. С. 213. 
increased all over the world, which is accompanied by the need for its constant improvement and makes it possible to achieve and maintain effective economic activity ${ }^{35}$. At the same time, requirements for the environment of the production itself, its safety for the environment, workers and society are increasing. According to this system of management of industrial enterprises are increasingly developed in integrated forms, which allows to take into account and harmoniously combine different aspects of production activity. EMAS system is not aimed at expanding economic responsibility and limiting the will of enterprises ${ }^{36}$. That is, enterprises are creating such economic incentives that encourage them to voluntarily adopt official directives in the field of environmental management. Today Ukrainian enterprises are experiencing a deep crisis, which is caused by certain objective and subjective reasons. Objective reasons are the environmental factors of the company. Subjective reasons are internal factors related to the orientation of the company, the management system, the system of supply, production and sales, organizational culture of the company, etc. In this case, one should not forget that, as V. Akulenko notes, the most important component of economic security is the human factor ${ }^{37}$.

Recommendation and eco-audit system is open to any organization that pays attention to improving the quality of its own environmental activities, regardless of ownership. The European Union also promotes such activities not only at large enterprises but also at medium and small firms, but the decision to extend the EU recommendation and eco-audit system to these categories of organizations is taken by the Member State. The need to study such issues as environmental management of production processes becomes relevant in the context of investing environmental policy programs and management in the field of environmental safety of enterprises, because stable functioning, growth of economic potential of any enterprise in terms of market relations largely depend on the availability of a reliable system environmental safety. The use of environmental management systems provides businesses with certain advantages, which include systematic reduction of negative environmental impact; systematic reduction of production and operating costs; reducing environmental payments and more

${ }^{35}$ Білик О. С. Екологічний менеджмент на промислових підприємствах України: зміст та сутність поняття. Экологический менеджмент. 2012. № 12. С. 52-53.

36 Декалюк О. В., Стасюк I. В. Впровадження екологічного менеджменту та аудиту для забезпечення екологічної безпеки підприємства. Вісник Хмельницького національного університету. 2010. № 2. Т. 1. С. 242.

37 Акуленко В. Л., Мамчук І. В. Екологічний менеджмент в контексті забезпечення екологічної безпеки підприємства. Вісник Хмельнищького національного університету. 2009. № 5. T. 1. C. 26. 
effectively complying with EU environmental legislation. Additional benefits include reducing the risk of accidents and the magnitude of their consequences; improving the competitiveness of the enterprise in the domestic and foreign markets, the possibility of developing new markets; gaining a positive image of the enterprise, improving relations with consumers, partners, investors, government bodies, and the public.

\section{CONCLUSIONS}

The measures currently being taken in the EU are currently insufficient to address the root causes of unsustainable consumption, as they are mainly aimed at mitigating its effects, and their participation is largely voluntary.

The overriding objective of voluntary instruments is to strengthen environmental responsibility through the reproduction of certain tools and procedures in EU secondary legislation, using industry proposals. Such instruments include voluntary agreements or initiatives, the eco-labeling system, the EU eco-management and environmental audit system, the environmental impact assessment and the environmental impact of the implementation of plans and programs.

Voluntary instruments use the principle of sustainable development as a dominant idea and at the same time reinforce the priority of industrial activity. It would be advisable to expand the scope of such instruments within the framework of horizontal environmental legislation, as well as to enhance the development of environmental reporting systems and environmental management of production processes, which will contribute to the establishment of a reliable system of environmental safety, health and wellbeing of people.

\section{SUMMARY}

The article deals with the analysis of voluntary instruments in the sphere of production. It includes voluntary agreements or initiatives that will enhance environmental responsibility; eco-labeling; the EU environmental management and environmental audit system; environmental impact assessment and environmental impact assessment of plans and programs. The author emphasizes that in order to better achieve environmental goals in the production sector, it is necessary not only to reproduce voluntary instruments in the secondary legislation of the European Union, but also to motivate producers to be responsible by using their proposals in industry.

The advantage of all these activities is the constant focus of public attention on the issue of interaction between production and the environment. These measures affect not only the establishment of product design in a more environmentally friendly way, but also the process of production development 
by introducing environmentally significant changes into product development, which is now a priority for the manufacturer.

Voluntary instruments use the principle of sustainable development as a dominant idea and at the same time reinforce the priority of industrial activity. For Ukraine, it would be advisable to expand the scope of such instruments within the framework of environmental legislation, as well as to enhance the development of environmental reporting and environmental management of production processes, which will contribute to the establishment of a reliable system of environmental safety, health and well-being of people.

\section{REFERENCES}

1. Акуленко В.Л., Мамчук І.В. Екологічний менеджмент в контексті забезпечення екологічної безпеки підприємства. Вісник Хмельницького національного університету. 2009. № 5. Т. 1. С. 21-26.

2. Білик О.С. Екологічний менеджмент на промислових підприємствах України: зміст та сутність поняття. Экологический менеджмент. 2012. № 12. С. 49-64.

3. Бут Ю.С. Управління процесами використання природних ресурсів в країнах Європейського Союзу : екологічний аспект. Виртуальная библиографическая справка. Объединенная справочная служба библиотек Украинь. URL: http://www.nbuv.gov.ua/ejournals/PSPE/2011_2/But_211.htm

4. Декалюк О.В., Стасюк I.В. Впровадження екологічного менеджменту та аудиту для забезпечення екологічної безпеки підприємства. Вісник Хмельнищького національного університету. 2010. № 2. T. 1. C. 235-242.

5. Дубовик О.Л. Международное право. М., 2003. 584 с.

6. Дубовик О.Л. Экологическое право ЕС : формирование, развитие, достижения и актуальные задачи. Право и политика. 2004. № 12. C. 58-67.

7. Кремер Л., Винтер Г. Экологическое право и политика Европейского Союза : законодательные основы, реализация, судебная практика. Политика и общество. 2006. № 6. С. 26-83.

8. Круглов В.В. Законодательство Европейского Сообщества в сфере охраны окружающей среды в промышленности. Экологическое право. 2005. № 2. С. 42-46.

9. Мельник Л.Г. Екологічна економіка : Підручник. Суми : Університетська книга, 2002. 346 с.

10. Мельник Л.Г., Дегтярьова І.Б. Свропейський досвід використання економіко-правових інструментів забезпечення сталого розвитку. Механізм регулювання економіки. Суми. 2012. № 1. С. 13-24. 
11. Политология : хрестоматия / Сост. М.А. Василик, М.С. Вершинин. М. : Гардарики, 2000. 843 с.

12. Потай О.А. Формування інтегрованої системи екологічного менеджменту промислових підприємств. Науковий вісник НЛГУ. 2009. Вип. 19.9. С. 212-216.

13. Редникова Т.В. Современные тенденции развития экологической политики в области производства продукции в Европейском Союзе. Политика и общество. 2006. № 6. С. 102-107.

14. Редникова Т.В. Формирование и реализация интегрированной политики в области производства продукции в ЕС на национальном уровне на примере Дании. Право и политика. 2009. № 12. С. 2465-2472.

15. Скрипчук П.М. Екологічне маркування: інноваційні та організаційні аспекти. Механізм регулювання економіки. № 1. 2007. C. 104-115.

16. Труш О.О., Андрієнко М.В., Ломовських Г.А. Формування та реалізація спільної екологічної політики Європейського Союзу в умовах сучасних інтеграційних процесів. Державне управління. 2014. № 1. URL: http://www.kbuapa.kharkov.ua/e-book/db/2014-1/doc/4/05.pdf

17. Шевчук В.Я. Екологічне управління : підручник. К. : Либідь, 2004. URL: http://pidruchniki.com/14860110/ekologiya/otsinka_vplivu_ navkolishnye_seredovische.

18. Andersen M.S., Jorgensen U. Evaluation of Cleaner Technology Programme 1987-1992 : Results, Diffusion and Future Activities. Copenhagen : Environmental Review, 1995. № 14.

19. Communication from the Commission to the European Parliament, the Council, the Economic and Social Committee and the Committee of the Regions - Environmental Agreements at Community Level - Within the Framework of the Action Plan on the Simplification and Improvement of the Regulatory Environment / COM (2002) 412 final. 14 p.

20. Directive 2000/60/EC of the European Parliament and of the Council of 23 October 2000 establishing a framework for Community action in the field of water policy. Official Journal. 2000. L 327. P. 1-73.

21. Directive 2001/42/EC of the European Parliament and of the Council of 27 June 2001 on the assessment of the effects of certain plans and programmes on the environment. Official Journal. 2001. L 197. P. 30-37.

22. Directive 2009/125/EC of the European Parliament and of the Council of 21 October 2009 establishing a framework for the setting of ecodesign requirements for energy-related products. Official Journal. 2009. L 285. P. 10.

23. Directive 2009/33/EC of the European Parliament and of the Council of 23 April 2009 on the promotion of clean and energy-efficient road transport vehicles (Text with EEA relevance). Official Journal. 2009. L 120. P. 5-12. 
24. Directive 2014/52/EU of the European Parliament and of the Council of 16 April 2014 amending Directive 2011/92/EU on the assessment of the effects of certain public and private projects on the environment Text with EEA relevance. Official Journal. 2014. L 124. P. 1-18.

25. Eritja Mar Campins. European Community Eco-Labeling Scheme / Ed. by Prof. Richard. Macrory. Reflections on 30 Years of EU Environmental Law. Groningen : Europa Law Publishing, 2006. P. 109-128.

26. European Commission, 2006b. European Commission, Environment, Eco-label. URL: http://ec.europa.eu/environment/ecolabel/index_en.htm.

27. From Conflict to Peacebuilding : The Role of Natural Resources and the Environment, UNEP 2009. URL: http://www.unep.org/pdf/pcdmb_ policy_01.pdf.

28. Intensified Product Oriented Environmental Initiative. Copenhagen : Environmental Protection Agency, Ministry of Environment, 1996. P. 13-14.

29. Modak P., Biswas A.K. Introduction to EIA, What is EIA in : Conducting Environmental Impact Assessment for Developing Countries. Tokyo-New York-Paris : United Nations University Press, 1999. P. 12-14.

30. Regulation (EC) № 1980/2000 of the European Parliament and of the Council of 17 July 2000 on a revised Community eco-label award scheme. Official Journal. 2000. L 237. P. 1-12.

31. Report from the Commission to the Council, the European Parliament, the European Economic and Social Committee and the Committee of the Regions on the application and effectiveness of the EIA Directive (Directive 85/337/EEC, as amended by Directives 97/11/EC and 2003/35/EC) / COM (2009) 378 final. URL: http://eur-lex.europa.eu/procedure/EN/198470.

32. Web-site Consumers Internationals. URL: www.consumersinter national.org/word

\section{Information about the author: Kachuriner V. L.,} $\mathrm{PhD}$, Associate Professor at the Department of State Law Disciplines, International Humanitarian University 33, Fontanska Road str., Odessa, 65009, Ukraine 
DOI https://doi.org/10.36059/978-966-397-178-0/121-142

\section{CRIME IN EPISTEMOLOGICAL-AXIOLOGICAL CONTEXT PARADIGMS OF QUALIFICATION AND COMPOSITION}

Klyuev O. M.

\section{INTRODUCTION}

The criminal code of Ukraine, which entered into force on September 1, 2001 , opened a new page in the history of domestic criminal law. Sixteen years is a sufficient period to sum up some results, to comprehend the way that science and practice have passed during this time in the application of the Criminal code.

The introduction of the criminal law covers multifaceted activities of state law enforcement agencies related to various issues, namely: criminal-legal assessment of the offense; sentencing proceedings; exemption from punishment and serving it; the application of compulsory measures of a medical nature.

Criminal-legal assessment of the offense consists of two components-the separation of criminal from non-criminal and the qualification of the crime. In practice, both components are as if one whole, and in theory they are different and are considered separately. The axiological concept of this approach is that the recognition of the offense as non-criminal eliminates the need to solve all other issues of criminal law and, conversely, if criminal causes such a need, and the qualification of the crime comes to the fore, that is, the establishment of compliance with the latter signs of a specific crime. Qualification of crimes is the basis for the imposition of punishment, exemption from criminal liability and punishment, and the like. And at the same time it allows to state that qualification of crimes makes the Central core of application of the criminal law in investigative and judicial practice. And here it should be noted that the implementation of the qualification of crimes by all law enforcement agencies and the court characterizes its activities as such that unites these bodies and the court with the same tasks and responsibilities, which ultimately binds them.

During the qualification of crimes there are numerous epistemological problems of criminal law in their various combinations, you are the problems and vulnerabilities of criminal law, theoretical concepts and the like. Here it is important to distinguish between the theoretical provisions of the qualification of crimes, or the theory of qualification of crimes, on the one hand, and the qualification of crimes in practice by investigators and judges, on the other. Theoretical positions reflect qualification of types of crimes within their 
description in criminal law norms. With regard to practical actions, it takes into account all, without exception, established and proven factual circumstances of the act in its personal manifestation. These distinctions show that the pure theory of qualification of crimes cannot recommend "ready recipes" of each separate crime because it is simply impossible to consider all nuances of the crime committed in various life situations. The theory of qualification of crimes will establish a fundamental scientific basis for criminal and legal assessment of criminal acts.

And today, when Ukraine is developing a legal state, the exact qualification of the crime in practice is one of the most important influences of such development not in words, but in reality.

This indicates the relevance of the proposed monograph and the author's forecast of a certain interest in it from practitioners and scientists, graduate students and students of higher law schools.

So, it can be stated that the composition of the crime is a legal basis for the qualification of the crime. Let us pay attention to the epistemological gap, because in the criminal law there is such a thing as" the composition of the crime", and the concept of "qualification of the crime" is not. By the way, their content in the criminal law is not defined. It is revealed in the theory of criminal law. As you can see, the theoretical provisions are the basis for the application of criminal law, namely: the qualification of crimes in the investigator and judicial practice.

\section{Qualification of crimes: epistemology, axiology, status}

1.1. Epistemological context of the qualification of the crime

In modern scientific legal literature, the issue of qualification of crimes is given considerable attention. In particular, in the textbook on criminal law of Ukraine edited by professors V. Stashis and V. Tation qualification of crimes is defined as the exact establishment of a socially dangerous act committed by the perpetrator of a specific crime, enshrined in the criminal law. Some authors interpret the qualification of crimes as "the establishment and legal consolidation of the exact responsibility between the signs of the committed act and the signs of the corpus delict provided for in the criminal law norm"1. Both definitions can be taken as a basis for a detailed disclosure of the content of the concept of "qualification of crimes".

In our opinion, this concept consists of four parts. The first determines that the qualification of the crime is an assessment of a criminal act, that is, an act that has all the signs of a crime under the criminal code of Ukraine.

\footnotetext{
${ }^{1}$ Kudryavtsev V. the General theory of qualification of pre-steps. Moscow: Yuridicheskaya Literatura, 1972. P. 8;
} 
If, assessing the act, the employee of the law enforcement Agency comes to the conclusion that it is not criminal, then the qualification of the action or inaction as a crime is excluded. It should be borne in mind that the qualification of crimes is a subjective category. Therefore, it is necessary that the person who gives a legal assessment of the offense, had, first, knowledge of criminal law, and secondly, the skills, on the one hand, to identify the signs of the committed act, and on the other - to compare the latter with the signs of the crimes provided for in the criminal code of Ukraine, as well as clearly adhere to the laws of logic, which make it possible to establish whether or not both coincide. As a consequence, it can be stated that the speed of qualification of crimes depends on the knowledge of the subject of criminal law and the level of his abilities.

The second part of the qualification of the crime is the signs of the committed act. In practice, these signs are reflected in criminal cases. They can also be used in the educational process as practical tasks in criminal law, and in the literature-in the coverage of criminal acts that have taken place or are fictional authors of crimes.

In practice definition of the specified signs are established by their analysis by the subject during which these signs are separated from others, are concretized and detailed.

The third part of the qualification of the crime, as already noted, is a comparison of the identified signs of the crime with the signs of the relevant article of the criminal code of Ukraine. Both scientists and practitioners call this part "signs of a crime, which characterize the objective side of a specific article of the criminal code of Ukraine and separate one crime from another. But it should be borne in mind that the signs of a crime are provided not only in the dispositions of articles of the General and Special part of the criminal code of Ukraine, but also in other legal acts, references to which are made in the blank dispositions of articles of the Special part of the criminal code of Ukraine.

The fourth part of qualification of crimes assumes establishment and legal fixing of exact correspondence between the signs given by us in the second and third parts. Such establishment consists in comparison of actual signs of the committed act with signs of concrete structure of a crime and a statement in case of coincidence of their identity.

Further the received conclusions concerning the guilty person are fixed or in the resolution on attraction to criminal responsibility, the indictment or in the sentence. That is, it is indicated that the actual signs of the committed act exactly correspond to the signs of a specific crime.

Therefore, qualification of crimes should be defined as establishment and legal fixing of exact correspondence between the actual signs of the 
committed and signs of structure of the crime provided by the criminal law and other laws and normative-legal acts encroachment on which are fixed in blank dispositions of articles of a Special part of UK of Ukraine.

Concerning practical workers, they under qualification of crimes understand establishment in the committed act of signs of the corresponding structure of the crime provided by article of the criminal code of Ukraine.

As you can see, the qualification of crimes, on the one hand, is a process, and on the other - the result. How the process will take place, firstly, the identification of the actual signs of the committed act, and secondly, the choice of criminal law, that is, the article of the Special part of the criminal code of Ukraine, and in the case of the latter-other laws or regulations to which there are references. And, at last, the last is a study of actions of the subject of qualification of crimes in their comparison. However, it should be noted that such a process is divided into these components only theoretically. In fact, in the thoughts of the practical worker, that is, the subject of the qualification of crimes, all these parts complement each other and are organically interconnected, and the whole process takes place as a whole. In other words, the conclusion that the factual characteristics of the offense correspond to the elements of a crime under the criminal code of Ukraine, and if the provisions of this article blanket, and even other laws or regulatory acts referenced in the specified disposition. At the same time, such consolidation occurs, as already noted, in the prepared document, where the signs of the committed act are fixed, provided for in a specific article of the Special part of the criminal code of Ukraine. And here practitioners should bear in mind that in this case, in order to reduce the registration of the offense, neither articles of the General part of the criminal code (except for cases of unfinished crime and complicity in it) nor other laws and regulations to which references are made in the article of the Special part of the criminal code of Ukraine, if its disposition is blank.

Some of the scholars and practitioners may object and say that a large number of circumstances and facts accompanies each crime. We believe that not all of these facts have criminal and legal significance, i.e. not all affect crime and its punishment. For example, the time of the offense is essential to prove the crime, however, from the point of view of criminal law for offences not affected. Thus, it can be stated that the establishment of the actual circumstances of the case corresponds to the legal norm, forms a certain crime, in its logical form-deductive syllogism. It established the actual circumstances are recorded in a smaller volume.

However, the qualification process as a whole can be reduced only to deduction, the achievement of truth is impossible without the relationship of deduction and induction, since the establishment of the actual circumstances 
of the criminal case, as well as the accumulation of various facts, occurs mainly by inductive means.

In the legal literature two types of qualification of crimes are considered: official (legal) and informal (doctrinal $)^{2}$.

The official (legal) qualification of crimes is the criminal-legal qualification carried out on a specific criminal case by a person authorized by the state, namely: an investigator, a Prosecutor, a judge, etc.

Unofficial (doctrinal) qualification of crimes is their legal assessment, which is carried out by individual citizens, including researchers, authors of articles, monographs, textbooks, manuals.

In our opinion, the unofficial qualification of the crime is not qualitatively the same and its content can be divided into two parts. To the first belongs the main informal part of the qualification of the crime, which is provided, as indicated above, by citizens. However, their qualification of a criminal act, as a rule, does not have any sign that the official qualification of the crime has. Therefore, this part should be called-unofficial qualification of crimes.

The second part of definition of informal qualification of crimes which, on the one hand, is given by participants of criminal process, that is accused, the defender, the victim, the suspect, the civil claimant and another in the statements from concrete criminal case, and with another - Plenum of the Supreme Court of Ukraine is of certain interest. As a rule, the content of the definition of the qualification of the crime is different.

It should be noted that the division of the qualification of the crime into official and unofficial is not related to the accuracy of the qualifications of the crime. Sometimes the unofficial qualification of the crime can be correct.

We will note that scientists consider qualification of a crime mainly concerning separate types of crimes (against property, bases of national security of Ukraine, against life and health of the person, etc.) which concern a Special part of criminal law of Ukraine.

\subsection{Axiology of crime qualification}

The value of qualification of crimes is multifaceted. It has a General social and criminal-legal character. General social value of qualification of crimes describes the state of the socio-legal system, on the one hand, is the Foundation of the rule of law in the state, on the other - occupies a Central place in formation of legal state in Ukraine. In General, the observance of the rule of law in the state, its provision is evidenced, first of all, by the extent to which repression is applied in accordance with the criminal law in General

${ }^{2}$ Kurinov B. Scientific bases of qualification of crimes. Moscow: Moscow state University, 1984. P. 20. 
and how objectively the qualification of committed socially dangerous acts in particular is controlled.

To assess the formation of the rule of law can be two parameters. The first is the content and form of the law, especially the criminal law. The meaning of the law is to what extent the state will, which, in fact, expresses the will of the bureaucracy, which is at the head of power, as well as large capital, corresponds to the will of the citizens of Ukraine; how justified are taken under the protection of the law public relations as the most important and valuable in the state; how the state reacts to crimes, that is, socially dangerous acts; as a matter of fact, and not declaratively, the crimes are differentiated by the degree of public danger reflected in the sanctions of the articles of the Special part of the criminal code of Ukraine.

As already noted, the criminal-legal significance of the qualification of crimes is multifaceted and appears in several cases. Distinguishing main and prominent ones, it is necessary to note that correct and accurate qualification of crimes is:

a) the enforcement of the law when administering justice;

b) reflection of socio-political and legal assessment of the offense;

c) the safeguarding of the rights and legitimate interests of the perpetrator and the promotion of individualization of criminal liability and punishment in accordance with regulations of the criminal code of Ukraine;

d) determination of possibilities of application of Institute of release from criminal responsibility and repayment of criminal record;

e) ensuring an order of investigation of crimes according to the CPC of Ukraine;

f) possibility of providing the correct characteristic of a condition, structure and dynamics of crime, and also development of effective measures of fight against it.

The above qualification of crimes will ensure compliance by law enforcement agencies, Executive authorities and the court with the constitutional principle of legality and the principles that follow from it.

The General situation, which vividly displayed the criminally-legal value of accurate classification of crimes is a provision contained in part 1 of article 2 of the criminal code, which provides that "the basis of criminal liability is any person committing a socially dangerous act which constitutes a crime under this Code" $"$.

The exact qualification of a crime is guaranteed the rights and legitimate interests of the perpetrator of the subject through individualization of criminal liability and punishment, and consequences that emerge as they implement the

${ }^{3}$ Ukrainian criminal code. Sumy: LLC "GDP Nostis”, 2015. 
article of the Special part of the criminal code that corresponds to the offense act, regulations of the General part of the criminal code regulating the possibility of bringing to criminal liability for preparation for a crime, sentencing, taking into account the degree of public safety not crime and of the perpetrator, and the like.

Taking into account the above, it can be argued that the correct qualification of the crime is important in criminology, since on its basis the qualitative structure of crime is highlighted and the necessary measures for its prevention are developed. If the qualification of crimes is wrong, it will give the wrong picture of the state and dynamics of crime, which, in turn, will lead to errors in the planning of preventive work. It should also be noted that the qualification of crimes has a certain importance in law enforcement, because the success or difficulties in qualification provide the legislator with information about the degree of law enforcement effectiveness of certain criminal law norms and can be the basis for making the necessary changes and additions to them ${ }^{4}$.

\subsection{The status of the crime in the system of offenses}

It is known that crimes are the most socially dangerous type of offenses. Encroachment on protected public relations, for example, encroachment on the life and health of a person, on sexual freedom and sexual inviolability, on the foundations of the constitutional system and others, as a rule, are criminal. However, there are many objects, attacks on which can be crimes and other offenses-civil delicts, administrative or disciplinary offenses. Therefore, it is very important to be able to separate the crime from other offenses, the responsibility for which is regulated in administrative, economic, tax, financial law and the like.

Crimes and non-crime offenses are distinguished by three main criteria: object; public danger; type of illegality.

From the stated follows that objects of crimes are interests which in other branches of the law are not present owing to their special value (for example, objects of crimes against bases of the constitutional system of Ukraine).

The closest to the criminal legislation on the diversity of protected interests is the Code of Ukraine on administrative offences (CAO) $)^{5}$. In accordance with article. 9 administrative Code administrative offense (misdemeanor) recognized illegal, guilty (intentional or careless) action or

\footnotetext{
${ }^{4}$ Sukhonos V. Criminal law of Ukraine. General part: textbook / V. V. Sukhonos . Sumy: University book, 2016. P. 46-55.

${ }^{5}$ Code of Ukraine on administrative offences. URL.: http://zakon3.rada.gov.ua/laws/show / 80731-10.
} 
omission, encroaching on public order, property, rights and freedoms of citizens, the established order of management and for which the law provides for administrative responsibility. The subject of its regulation is the dignity of man and citizen, sanitary and epidemiological safety of the population.

With regard to public danger, it is and remains an exceptional sign of crime. Despite the fact that incessant offenses are also to some extent negative, and their nature and degree of antisocialist never reach the level of criminal situation, which in criminal law has the name of public danger. And although some crimes at first glance, and resemble administrative offenses, but always cause more harm, their guilt is anti-social, criminal motives, and methods of committing more socially dangerous. Practice shows that the legislator and the courts in the interpretation of the rule of law always try as accurately as possible to distinguish between crimes and offenses. First, attention is drawn to the amount of harm caused to a person, society, the state. Material damage is confirmed in formal terms, and physical-in clearly fixed indicators of disability, organs or their functions (Art. 121-128 of the criminal code of Ukraine). In war crimes, to distinguish the crime from other disciplinary offenses of the criminal code of Ukraine as a sign calls the time, circumstances, place of Commission of the crime. For example, unauthorized abandonment of a military unit or place of service is qualified under part 1 of article 407 of the criminal code of Ukraine, if the subject did not appear after three dobi7, and up to three days - it will be a disciplinary offense.

If we take the subjective side of the crime, the law most often draws attention to the purpose, motive and form of guilt in General, distinguishing the crime from the non-criminal offense. For example, intentional slight bodily injury (Art. 125 of the criminal code) is a crime, and careless-a misdemeanor ${ }^{6}$.

A clear distinguishing feature is the type of illegality. Crime is always prohibited by criminal law under threat of punishment. Non-criminal offences are regulated by other branches of law, as already noted.

The difference between crime and offense applies to sanctions. For crimes comes criminal responsibility more strict, than measures disciplinary, economic, labor influence.

The need to distinguish between crimes and disciplinary offenses usually arises in the Commission of official and military crimes. Practice shows that quite often for disciplinary offenses hides a crime, including for violation of safety regulations. It should also be borne in mind that crime is always an act, and immoral acts can manifest themselves not only in command, but also in a way of thinking or speaking, and they are always less anti - social. As a rule,

\footnotetext{
${ }^{6}$ Ukrainian criminal code. Source: LLC “GDP NOTIS”, 2015. P. 55.
} 
the damage from them has a socio-psychological content: humiliation of honor and dignity of the person, etc. I would like to note that a clear distinction between crimes and immoral offenses takes place on the basis of illegality. If crimes are prohibited by criminal law, then immoral offenses are not regulated by legal norms at all. Norms of dignity can be written and oral (e.g. customs). The first include the Hippocratic oath-the code of medical ethics, the code of officer honor, the ethical code of journalists.

It is also necessary to take into account the requirements of part 1 of article 11 of the criminal code of Ukraine, which clearly fixed three signs of crimes: predictability in the laws on criminal responsibility, public danger of the act and guilt. The first-the predictability of the act of the criminal code of Ukraine - is formal, which reflects the illegality. Other signs-public danger and guilt-are material, revealing the socio-psychological nature of the crime.

However, part 2 of article 11 of the criminal code of Ukraine directly indicates that "it is not a crime to act or omission, which, although formally and contains signs of any act provided for by this Code, but through insignificance does not pose a public danger, that is, did not cause and could not cause significant harm to a natural or legal person, society or the state"7.

In order to apply part 2 of article 11 of the criminal code of Ukraine should, as noted above, to establish, first, the presence of crime the bottom surface of the formal criteria of an act which provided for in the criminal code, that is, all those objective subjective criteria that in the appropriate article of the Special part of the criminal code to characterize a certain crime. For example, if the abuse of power or official position (part 1 of art. 364 of the criminal code of Ukraine) there is no significant harm to the protected rights, freedoms and interests of individual citizens or the state or public interests, or the interests of legal entities, and it was not aimed at causing such harm, such abuse does not fall under part 2 of article 11 of the criminal code of Ukraine, because it does not Such an act does not refer to crimes, but to official misconduct. Secondly, it is necessary to recognize the acts such that only formally contains the signs of the act provided for by the criminal code of Ukraine. That is, it does not contain the public danger that is typical of the crime, and therefore is considered insignificant. Thirdly, it is necessary to take into account the subjective characteristic of a minor act: it objectively not only did not cause harm, but also subjectively was not aimed at causing significant, substantial harm. Only the totality of these conditions makes it possible to define the acts as insignificant, that is, not a crime.

Proceeding from the stated, we can state that crimes from non-criminal offenses and immoral offenses differ on the General object, wider and various,

\footnotetext{
${ }^{7}$ Ukrainian criminal code. Sumy: LLC “GDP Nostis”, 2015. P. 9.
} 
than in other branches of the right; anti-social system which in crimes is the highest, and is called "public not safety".

The basis of the distinction in the most public danger is harm, because the interests of citizens, society and the state are protected by law. Among other signs it is possible to define direct intention, motivation, socially dangerous actions, in particular group, with use of official position or the weapon.

It should be remembered that in criminal law it is reasonably recognized that public danger is the criterion that should be the basis for distinguishing crime from other offenses. However, there is no unity among scientists on the question of how exactly it performs this differentiating function.

\section{Corpus delicti: epistemological and axiological contexts}

\subsection{The composition of the crime in the epistemological context}

The definition of crime (both legal and doctrinal) indicates the legal and social characteristics inherent in the latter. These features (illegality, public danger, guilt and punishability) make it possible to separate the criminal act from other offenses and acts that are not a crime. Qualification of crimes, if they are defined in the most General form as a result, is the fixation of the identity of the signs of the actually committed socially dangerous act to the signs of the corpus delicts. Therefore, in order to distinguish from the total number of criminal acts a certain crime (for example, theft or murder, robbery or desertion) and there is a special concept of the crime. This gives grounds to argue that the study of the crime is the main core of the theory of criminal law.

In the study of crime examines some of the defining provisions of the General part of criminal law of Ukraine, which, on the one hand, the basis of specific offences and is the subject of his Particular part, and on the other specify a connection terminal of the latter. In the theory of criminal law, the corpus delicts is defined as a set or system of objective and subjective features that, in accordance with the criminal law, characterize a socially dangerous act as a crime ${ }^{8}$.

The composition of the crime received this name precisely because it consists of several parts that have the name of elements of the crime. It is known that four elements belong to the composition of the crime, which in their totality form an interconnected system and are in the composition of the evil in a specific sequence, that is, each element has its pre-assigned place. This rigid sequence is due to the specificity of each element and the relationship between them. The elements of the crime are: the object of the

\footnotetext{
${ }^{8}$ Halabala M. Criminal-legal science of independent Ukraine. Problems of the General part: the textbook / M. Halabala. Kyiv: Yurinkom Inter, 2013. P. 37-74.
} 
crime; the objective side of the crime (the crime); the subject of the crime; the subjective side of the crime (corpus delicts).

Therefore, the full structure of a crime have to be all four elements. The absence of at least one of them determines the absence of the crime as a whole. This gives the right to argue that in fact the criminal law and its application in practice indicate that each element of the crime should be specific. It consists that as a part of a crime the set of the signs characterizing its elements and structure as a whole which are inherent, according to the criminal law, to a concrete type of a crime contains ${ }^{9}$. In other words, the composition of the crime should be understood as a homogeneous group of legal features that characterize the crime from one side, for example, the composition of murder, theft, robbery, banditry and the like. In a particular crime, the General features inherent in this particular type of crime must be accumulated, which are revealed in each individual act of this type. At the same time, in case of manifestation of many separate acts as signs of the structure of crime General for this type in the criminal law those which, first, repeat in any separate act of a concrete type, secondly, are essential, and, thirdly, characterize their public danger are recognized.

Specific elements of crimes and their signs are provided in the criminal law-articles of special and General parts of the criminal code of Ukraine. They can also be defined in other laws or regulations, references to which are in many blank dispositions of articles of the Special part of the criminal code of Ukraine.

If you go deeper into the theory of criminal law, it should be noted that in the General understanding of the composition of the crime reflects the laws of construction of any particular crime and its elements, as well as concentrated the concept of all, without exception, the elements and features inherent in all specific crimes, and the signs manifested in individual crimes. This concept is the theoretical basis for the knowledge of specific elements of crimes in their concretized sense, ordered, systematic form. A common understanding of the crime and its contents are the result of using the scientific method of movement from abstract to concrete thinking, regardless of documented application of this method in the minds of builder this concept or not.

It can be argued that the correct qualification of crimes is impossible without the presentation of the composition and content of the relevant legal norms, that is, without their interpretation. Indeed, if the crime itself is a socially dangerous act of a person, then after carrying out certain work from the General to the private, we can argue that there are signs of a crime, and

9 Criminal law. General part: the textbook/ OTV. edited by I. Kozachenko and Z. Neznamova. Moscow: Norma, 1997. P. 114. 
this is a legal understanding defined in the criminal law. It should be remembered that the number of signs of the crime and the composition of the crime is heterogeneous, because the latter always has a set of typed signs and its volume indicates a specific crime, that is, in fact, is a crime. And since the composition of the crime always covers not the actual socially dangerous act, but all such acts of a certain kind, it differs from each crime. If a specific composition is a legal concept of a certain kind, then the General concept of composition is the concept of the structure and characteristics of all specific compositions of crimes. It summarizes the features that characterize the object, the objective side, the subject, the subjective side of all crimes, which is in the criminal legislation. And, therefore, these common signs and there is ostensibly a theoretical Foundation for the study of specific crimes. It should be understood that the General and specific crimes have different purposes.

The concrete structure of a crime is definition in the criminal law of a crime of a certain type, and therefore if in act of the person all signs of a concrete structure of a crime are established, it is the basis for criminal responsibility.

Depending on the General understanding of the crime in the theory of criminal law distinguish its generic and species composition. The first is a generalized characteristic of homogeneous crimes having a set of features inherent only in these crimes. Homogeneous crimes in the current Criminal code of Ukraine are in one section of its Special part, for example, Section II "crimes against life and health of the person"10. In addition, here it should be remembered that the generic composition covers the General characteristic of the species composition of this. The specific structure of a crime is the characteristic of separate types of the crimes United on the General sample in one Chapter of the corresponding section of the criminal code of Ukraine. For example, sections III, IV, V, etc ${ }^{11}$.

It is important to understand that the composition of the crime - a real system of signs, and not the fruit of human imagination. And if it is an objective reality, then it can be known and used in practical activities. This makes it possible to assert that reflected and detailed in the consciousness of the practical worker the content of each specific crime, its elements and features provides an opportunity to compare: a) this crime, its elements and features; b) actually committed socially dangerous act and its features.

It is also important to determine the relationship between the concepts of "crime" and "corpus delicti". These concepts are interrelated, but not

\footnotetext{
${ }^{10}$ Criminal law, General part, textbook ed. Kharkiv: Pravo, 2010. P. 85.

${ }^{11}$ Gonchar T., Streltsov, E., and such famous O. Criminal law of Ukraine. General and special parts 6 tutorial. Kharkiv: Odyssey, 2013. P. 29.
} 
identical. First, the concept of crime is characterized by four characteristics, namely: public danger, illegality, guilt and punishability. The concept of corpus delicti is also characterized by four, but not signs, but elements, which, as noted above, include the object, the objective side, the subject and the subjective side. Secondly, the concept of corpus delicti does not include such a feature of the crime as punishability. Thirdly, the concept of crime separates all criminal from all non-criminal, and the concept of crime defines each type of crime and separates it from others, which affects the legal assessment of the offense. Fourth, the concept of crime reflects the social and legal essence of any crime, and the concept of the crime-its legal structure. In addition, the concept of crime and the specific elements of crimes are defined in the criminal law. Thus, the concept of crime is defined in article 11 of the criminal code of Ukraine, and the specific crimes in the articles of the Special part and V. 18-49 of the General part of the criminal code of Ukraine, as well as, as already noted, other laws and regulations to which there are references in the blank dispositions of the special part of the criminal code of Ukraine.

It should be remembered that each element of the crime is characterized by features that are defined in the criminal law. In the General understanding of the corpus delicti, the objective and subjective features that characterize it are divided into mandatory, including alternative, and optional. Obligatory signs are such signs which presence is necessary in any structure of a crime, and absence at least one of them excludes existence of structure of a crime.

Optional are the features that are in each part of the crime: in some parts of the crime they are provided for and are mandatory for these parts, and in others-not.

Each element in the General understanding of the crime is characterized by mandatory and optional features. Thus, the object of the crime has one mandatory feature-that is, the object and two optional features: 1) the subject of the crime and 2) the victim of the crime.

The objective side of the crime is characterized by a mandatory feature-the act and eight optional features: 1) consequences; 2) causal relationship between the act and the consequences; 3) place; time; 5) circumstances (conditions); 6) method; 7) tools and 8) means of committing a crime.

It should be noted that the consequences and the causal relationship between the act and the consequences are an optional feature of all crimes and at the same time mandatory for crimes with a material composition.

As for the subject of the crime, it has three mandatory and one optional feature. Mandatory are: a natural person (article 18 of the criminal code of Ukraine); a sane person (article 19 of the criminal code of Ukraine); a person who has reached the age of criminal responsibility (article 22 of the criminal code of Ukraine). 
Optional is provided by the criminal law in addition to the above feature that characterizes the characteristics of the subject of the crime, that is, "special subject of the crime".

The subjective side of the crime is the inner side of the crime, which reveals the mental processes that characterize the consciousness and will of the person at the time of the crime. It has one mandatory feature, which is guilt and two optional features, which include: a) motive And b) purpose.

\subsection{Criminal law and corpus delicti}

It is known that the basis of the qualification of the crime is a specific crime, provided by the disposition of the relevant article of the Criminal code of Ukraine. The concrete structure of a crime is defined in the criminal law not as a certain whole, and in the form of its signs. A sign of a crime is a concept expressed in a criminal law by one term or several, as well as, in some cases, in another law and/or other normative act or international Treaty. It should be borne in mind that the signs of a crime from the standpoint of their definition in the criminal law can be classified according to some criteria. After the mandatory and optional features are: normative origin; criminal-legal significance; degree of public danger; epistemological essence; certainty; degree of permanence; specificity of criminal description in the law.

Let's analyze some of them. So, based on such criterion as a normative source, the signs of a crime envisaged in the first article of the Special part of the criminal code, which establishes liability for the crime; secondly, in the titles of the sections of the criminal code of Ukraine; thirdly, to articles of the General part of the criminal code of Ukraine; fourth, in the other (noncriminal) laws or other legal acts of Ukraine, are referenced in the blanket the dispositions of articles of the Special part of criminal code of Ukraine, fifth, in the international treaties of Ukraine, which also has a link.

In the disposition of the articles of the Special part of the criminal code of Ukraine, the signs that individualize a specific crime are determined, and also separate this composition from other crime compositions, while always all these signs belong to the objective side, and if they are present, there are all optional signs.

In addition, the dispositions of some articles of the criminal code provides for individual features that characterize the object of the crime (for example, in part 1 of article 296 of the criminal code of Ukraine), the subject of the crime (e.g. art. 364, 364-1, 365, 365-2, 368) and a subjective side (separately in article 115, 119 and in many other articles of the criminal code of Ukraine). It should be noted that the signs of the objective side of the specific corpus delicti are provided only in the dispositions of the articles of the Special part of the criminal code of Ukraine. 
In the names of sections of the criminal code of Ukraine are defined, we can say, typical, as well as generic objects of crimes, for example, in the name of the second section to such an object can be attributed to a person, and to the generic object-his life and health.

With regard to the norms of the General part of the criminal code of Ukraine, they contain, first, signs common to all or many crimes, characterizing their object and subjective side; secondly, signs inherent in the unfinished crime (preparation, attempt) and the composition of the crime against its perpetrators (organizer, instigator and accomplice, article 27 of the criminal code of Ukraine), and thirdly, signs, the presence of which excludes the crime as such. For example, in part 1 art. 1 of the criminal code specifies certain objects that are protected by law: legal protection of the rights and freedoms of man and citizen, property, public order and public security, environment, the constitutional system of Ukraine from criminal encroachments, peace and security of mankind ${ }^{12}$. However, this list is not exhaustive, the final version is listed in the sections of the criminal code of Ukraine.

The subject of a crime is defined in part 1 of article 18 of the criminal code of Ukraine, and in article 19, 20, 22 of the criminal code of Ukraine such its signs as sanity, age, limited sanity are concretized.

In Art. 23 of the criminal code of Ukraine certain wines and its forms, and in Art. 24, 25 of the criminal code of Ukraine these forms are specified. Part 2 of article 13 of the criminal code of Ukraine contains the definition of an unfinished crime, and articles 14 and 15 of the criminal code of Ukraine specify its stages.

Article 26 of the criminal code of Ukraine defines the concept of complicity, the content of which is disclosed in articles 27, 28, 29 of the criminal code of Ukraine. It should be noted that it is in these articles that the signs of a crime in the acts of accomplices who are not its perpetrators are reflected and enshrined in the articles of the Special part of the criminal code, but act as an organizer, instigator or accomplice. As already noted, the General part of the criminal code contains rules that exclude the criminality of the act and, accordingly, the composition of the crime. These include the signs provided for in part 2 of article 11 of the criminal code of Ukraine, part 2 of article 22 of the criminal code of Ukraine, part 2 of article 31 of the criminal code of Ukraine, art. 36-43 criminal code of Ukraine.

As already noted, according to part 2 of article 11 of the criminal code, "it is not a crime to act or omission, which, although formally and contains

\footnotetext{
${ }^{12}$ Sukhonos V. Criminal law of Ukraine. General part: textbook / V. V. Sukhonos. Sumy: University book, 2016. P. 59-65.
} 
signs of any act provided for by this Code, but through insignificance does not pose a public danger, that is, did not cause and could not cause significant harm to a natural or legal person, society or the state" ${ }^{" 13}$. According to the specified norm the sign causing existence of structure of crime is absence of public danger of the committed.

It should be noted that articles 36-43 of the criminal code of Ukraine provide for circumstances precluding the criminality of the act, which contains signs precluding the presence of a crime.

In blank dispositions of articles of a Special part of UK or signs of structure of a crime are not specified, or are covered, but not all. They are defined in whole or in part in other (not criminal) laws or other normative legal acts of Ukraine or international treaties, references to which are in the dispositions of the above ${ }^{14}$.

Signs of corpus delicti in its significance can be divided into two groups: 1) positive 2) negative. The first group includes signs indicating the presence of a crime, and the second-its absence. Such terminological name signs offered exclusively from the point of view of their influence on the presence or absence of crime, because with a General social position, their values are diametrically opposed: positive, that is acceptable, are those signs that indicate a lack of evidence and negative, that is unacceptable in his presence.

If you carefully read the dispositions of the articles of the Special part of the criminal code of Ukraine, you can understand that there are more positive signs than negative ones. According to the degree of public danger signs of a crime are divided into the following groups: constitutive - is inherent in both the basic and the qualified and preferred offences (article 66 and 67 of the criminal code); qualified - signs which constitute aggravating circumstances included in the offense (article 67 of the criminal code); preferred characteristics are extenuating circumstances (article 66 of the criminal code).

Aggravating and mitigating circumstances are, respectively, qualified and privileged features. However, the latter do not affect the qualification of the crime, but are taken into account only in the case of sentencing.

For gnoseological, essence signs can be divided into two groups: objective-signs that characterize the object and the objective side of the crime; subjective-the subject and the subjective side of the crime.

Academician V. Kudryavtsev proposes to divide the signs of the crime by the criterion of certainty. In his opinion, the signs of a crime can be divided into: certain-signs, the content of which is disclosed by the legislator is not

\footnotetext{
${ }^{13}$ Ukrainian criminal code. P. 53-62.

${ }^{14}$ Sukhonos V. Criminal law. The General part of: the textbook / Sukhonos V., A. Klochko, R. Belokon ; for zag. Sukhonos V. Summa, 2015. P. 62-65.
} 
included in the law; evaluation signs, the content of which is not disclosed, but is largely determined by the consciousness of the lawyer applying the law, taking into account the requirements of the criminal code and the circumstances of a particular.

Agreeing with the given definition of estimated signs, it would be desirable to object to the author of the specified work where he carries estimated signs to one of varieties of variable signs ${ }^{15}$ as, first, estimated and variable signs are independent and various legal categories, and, secondly, the essence of estimated signs does not change during action of the concrete criminal law. A lawyer discloses their content subjectively, according to his experience and legal knowledge, as well as adherence to a particular theoretical concept of criminal law, interests, etc. In addition, therefore, can be RES-Nay. Therefore, according to the degree of constancy, the signs of the crime should be divided into two groups: permanent - their content remains unchanged for the entire time of the criminal law and does not depend on the circumstances of the crime; non - permanent (variable) - the content can be changed without changing the text of the disposition of a particular article of the Special part of the criminal code of Ukraine ${ }^{16}$.

In our opinion, giving the characteristics of intermittent signs of a crime, there are two of them: 1) blanket - that is, as already mentioned, the features provided in other (non-criminal) laws, other legal acts or international treaties of Ukraine, links to which are provided in the blank in dispositions of articles of the Special part of criminal code of Ukraine and 2) the signs experiencing due to changes in norms of General part of the criminal code of Ukraine.

In the legal literature (mainly in Russia) it is proposed to divide the signs of the crime according to the specifics of the terminological definition in the law, that is, descriptive. It is impossible to agree with such statement as in the description division of signs on such which are defined is supposed: a) common terms (for example, the state or personal property); b) scientifically-theoretical terms (for example, epizootics), c) special legal terms (for example, plunder) ${ }^{17}$.

It should be noted that in the above classification system of signs of the crime, any sign has its place in each classification group. For example, someone else's property as the subject of the offense is an optional sign, and as a subject of theft under articles of section 6 of the criminal code of Ukraine - obligatory sign of structure of a crime and is seen as a sign: which

\footnotetext{
${ }^{15}$ Brainin M. Criminal law and its application. Moscow: Legal literature, 1967. P. 59-63.

${ }^{16}$ Sukhonos V. Criminal law of Ukraine. General part: textbook / V. V. Sukhonos. Sumy: University book, 2016.

${ }^{17}$ Naumov V. Russian criminal law. Common part. Course of lectures. Moscow: BECK, 1999. P. 154.
} 
provides a specific article of the Special part of the criminal code of Ukraine; positive; behavior; objective; determined; constant; as described in the criminal law commonly used term.

Depending on the reflection in the criminal law-articles of the special part of the criminal code of Ukraine-the elements of the crime are classified on three grounds: the degree of public danger; the method of description; design features.

According to the degree of public danger, the elements of crimes are divided into three types: basic; qualified; privileged $^{18}$.

\subsection{Axiological paradigm of the crime}

The meaning of the crime is diverse. It is not equally applied to the specific crime and to the General concept of the crime. The concrete structure of a crime has practical value, and the General concept of structure of a crimeis fundamental-applied, theoretical-practical. In addition, the specific composition of the crime has both General social and criminal-legal significance. The General social significance is manifested in the fact that in the aggregate of signs that form a specific crime, the negative assessment of society, the state and the law of the relevant behavior of the subject is highlighted, that is, the presence of the crime is a prohibitive norm. it can still be defined as the antinorm in the behavior of a member of society ${ }^{19}$.

The meaning of a particular crime is determined by the following: a) it is, as a rule, the legislative basis for the criminal-legal assessment of the committed act, namely: the qualification of the crime. The concrete structure of a crime can be called a standard with which signs of the committed act are compared; b) plays the main role in the process of qualification of a crime. The practical worker who is carrying out this process, compares signs of actually made act with the corresponding signs of concrete structure of a crime and, in such a way chooses the necessary norm of UK of Ukraine which forbids to make it; c) the correct, according to the law definition of concrete structure of a crime and all its signs provides exact qualification of a crime, that is such which the practical worker perceives as result because gives the chance to compare the specified signs with signs of actually committed act, to establish and legally fix conformity between them; d) establishment of identity, on the one hand, signs of concrete structure of a crime and, on the other - signs of actually committed act, guarantees to the subject who committed a crime, to demand to qualify its acts precisely with article of UK

${ }^{18}$ Kudryavtsev V. General theory of qualification of crimes / V. Kudryavtsev. - Moscow: Legal literature, 1972.

${ }^{19}$ Mychko N. Criminal law of Ukraine. Donetsk, 2006. P. 95. 
of Ukraine; e) establishment of concrete structure of a crime and all its signs is a prerequisite of the principle of legality during carrying out quicklyinvestigative actions and judicial proceedings at application of criminal-legal norms in practical activity ${ }^{20}$.

It should also be noted that the value of the General concept of a crime due to the relatively wide range of factors, namely: a) legal structure of any particular crime patterns and a build like this composition as a whole and each of its components and characteristics reflects the overall concept of the offense; b) the investigated concept is a theoretical basis of a specific corpus delicti, its elements and signs, because their inherent concentrates on General and specific; c) a General understanding of structure of a crime is a scientific basis, the Foundation of in-depth, specific knowledge of each of the elements of all specific offences; g) the notion is a methodological prerequisite of rational studying and learning the essence of certain specific offences, their elements and characteristics; d) this concept is a scientific basis, which ensures the formation and implementation of the intellectual component of qualified and civilized law-making that is implemented as in the definition, the formulation of criminal law norms and their improvement; e) in practice, the General concept of the corpus delicti is a theoretical prerequisite to understand the meaning of a particular corpus delicti, its elements and features in the application of criminal law ${ }^{21}$.

It should be noted that in the science of criminal law, the qualification of crimes is considered and investigated in relation to the qualification of certain types of crimes (for example, against property, the environment, etc.), which is the subject of study of a Special part of criminal law. The value of qualifications is diverse. Indeed, the establishment in the act of signs of a crime is achieved only by qualification, which is the legal basis for bringing a person to criminal responsibility, the use of procedural coercion, i.e., the legal basis for criminal responsibility and punishment of the person who committed the crime or his release from criminal responsibility and punishment. Thus, the qualification of the crime reflects not only protective criminal-legal relations, but also related with them criminal-procedural and criminalExecutive relations. Therefore, the correct qualification of crimes is the observance of the principle of legality in the activities of law enforcement agencies and the court. In addition, it should be noted that the correct qualification of the crime is of important criminological importance, because

${ }^{20}$ Sukhonos V. Criminal law of Ukraine. General part: textbook / V. V. Sukhonos . Sumy: University book, 2016. P. 46-55.

${ }^{21}$ Sukhonos V. Criminal law of Ukraine. General part: textbook / V. V. Sukhonos. Sumy: University book, 2016. 
on its basis the qualitative structure of crime is manifested and measures to combat it are developed. If the qualification is wrong, it will not give a real picture of the state and dynamics of crime, which will lead to errors in planning the fight against crime.

Qualification of a crime is also important for law-making work, because successes or difficulties in qualification show the legislator the degree of law enforcement effectiveness of certain criminal law norms and can be the basis for their changes or additions ${ }^{22}$.

Given allows to conclude about the importance of specific categories of crime and the General concept of a crime for law-making and law enforcement practice and theory of criminal law.

\section{CONCLUSIONS}

It is known that the fight against crime in all its forms in recent years has increasingly attracted the attention of legal scholars. Criminological science considers the issues of combating crime in a single context with other social problems associated with the further development of economic relations in Ukraine and improving the living standards of the population of the state. For this purpose it is necessary to ensure effective improvement of planning and development of complex programs on the most important scientific, technical, economic and social problems. Crime also belongs to the latter category. In Ukraine, there is an increase in organized crime and corruption, it is a complex social phenomenon. Criminal law is an instrument of social policy, but it cannot be a universal, basic, most effective means of combating crime. And in some cases, it simply cannot eradicate, for example, corruption phenomena.

Despite the above, it should be noted that the correct qualification of crimes is important for law enforcement officials and the court. No wonder the criminals by hook or by crook mislead these bodies to avoid responsibility. Therefore, the ability to correctly and quickly qualify the crime, that is, to make a choice of criminal law, accurately reflecting the actual circumstances of the case, allows to distinguish the criminal act from the non-criminal; to give them a legal assessment in accordance with the law; to determine those facts, which reflect the characteristics of the offense and must be proved in the manner specified by the criminal procedural legislation (UPK), which will make it possible in future to promptly gather evidence and secure the material, which confirms the Commission of a crime guilty. So, due to the fact that, on the one hand, the possibilities of the criminal law are

\footnotetext{
${ }^{22}$ Naumov V. Russian criminal law. Common part. Course of lectures. Moscow: BECK, 1999. P. 154.
} 
objectively limited by it to the established principles, as we wrote above, and on the other - the procedural framework of proof, it is not entirely justified to link the increase in the effectiveness of the fight against crime in the first place with changes in criminal legislation. However, it is adopted in order to contribute as much as possible to the solution of this problem. In conclusion, I would like to draw the attention of practitioners and scientists that from the point of view of criminal law, this will always be a fight not "in General" against crime, including organized, corruption-related, but with specific manifestations of socially dangerous behavior of subjects; not with phenomena in General, but with personalized excesses of representatives of criminal organizations, corrupt officials, individual criminals. Therefore, we believe that the task of the science of criminal law and criminology is to continue the study of these negative phenomena, to accurately determine the boundaries of the criminal-legal struggle against them, despite the obstacles created by persons interested in corruption.

\section{SUMMARY}

In the article based on modern achievements of the theory of criminal law the Institute of corpus delicti is investigated. Attention is paid to both axiological and epistemological aspects of the crime, its structure and theoretical and practical aspects of implementation are considered.

\section{REFERENCES}

1. Criminal law of Ukraine: General part: textbook / Y. Baulin, V. Borisov, V. Tyutyugin, etc.. The 4th form., rewritten. and extra. Kharkiv: Pravo, 2010. P. 94.

2. Kudryavtsev V. the General theory of qualification of pre-steps. Moscow: Yuridicheskaya Literatura, 1972. P. 8;

3. Kurinov B. Scientific bases of qualification of crimes. Moscow: Moscow state University, 1984. P. 20.

4. Ukrainian criminal code. Sumy: LLC “GDP Nostis”, 2015.

5. Sukhonos V. Criminal law of Ukraine. General part: textbook / V.V. Sukhonos . Sumy: University book, 2016. P. 46-55.

6. Code of Ukraine on administrative offences. URL: http://zakon3.rada.gov.ua/laws/show / 80731-10.

7. Ukrainian criminal code. Sumy: LLC “GDP Nostis”, 2015. P. 183.

8. Ukrainian criminal code. Source: LLC "GDP NOTIS”, 2015. P. 55.

9. Ukrainian criminal code. Sumy: LLC “GDP Nostis”, 2015. C. 9.

10. Halabala M. Criminal-legal science of independent Ukraine. Problems of the General part : the textbook / M. Halabala. Kyiv: Yurinkom Inter, 2013. P. 37-74. 
11. Criminal law. General part : the textbook / OTV. edited By I. Kozachenko and Z. Neznamova. Moscow: Norma, 1997. P. 114.

12. Criminal law, General part, textbook ed. Kharkiv: Pravo, 2010. P. 85.

13. Mychko N. Criminal law of Ukraine. Donetsk, 2006. P. 95;

14. Gonchar T., Streltsov, E., and such famous O. Criminal law of Ukraine. General and special parts 6 tutorial. Kharkiv: Odyssey, 2013. P. 29.

15. Sukhonos V. Criminal law of Ukraine. General part: textbook / V.V. Sukhonos. Sumy: University book, 2016. P. 59-65.

16. Ukrainian criminal code. P. 53-62.

17. Sukhonos V. Criminal law. The General part of: the textbook / Sukhonos V., A. Klochko, R. Belokon ; for zag. Sukhonos V. Summa, 2015. P. 62-65.

18. Kudryavtsev V. General theory of qualification of crimes / V. Kudryavtsev. - Moscow: Legal literature, 1972.

19. Brainin M. Criminal law and its application. Moscow: Legal literature, 1967. P. 59-63.

20. Sukhonos V. Criminal law of Ukraine. General part: textbook / V.V. Sukhonos. Sumy: University book, 2016.

21. Naumov V. Russian criminal law. Common part. Course of lectures. Moscow: BECK, 1999. P. 154.

Information about the author: Klyuev O. M., Doctor of Law, Professor, Director of the Kharkiv Scientific Research Institute of Forensic Examinations N.A. Prof. M. S. Bocarius of the Ministry of Justice of Ukraine 8-A, 49 Zolochivska str., Kharkiv, 61177, Ukraine 


\section{THE LEGAL ORDER AS A FACTOR OF INVESTMENT ATTRACTIVENESS OF UKRAINE FOR DOMESTIC AND FOREIGN ENTREPRENEURS}

\section{Kryzhanovskii A. F.}

\section{INTRODUCTION}

Legal order, as a phenomenon "integrally" reflecting the legal climate in all spheres of society, including economy, business, investment, greatly affects the investment attractiveness of the country. In order to improve the investment attractiveness of their own country, the authorities should take into account that business is extremely sensitive to changes in security and guarantees, stability and reliability of its operating conditions in investment country. The author analyzes various aspects of the Ukraine Government policy concerning strengthening of the legal order in the economic sphere, regulatory activity, financial guarantees and personal security as factors of our country's investment attractiveness in the current conditions and in the future.

\section{The legal order as the context of being human and society}

Every person, if asked, whether they "feel" the legal order in their environment is likely to answer affirmative that question. Indeed, a person feels that the events around indicate either relative safety, predictability, orderliness of social life, or vice versa, threatened by some danger from the surrounding world, which is dominated by disorder, unpredictability, and therefore that it can protect. Determining the level (degree, quality) of orderliness of others around the world is an immanent need, because only by "satisfying" it we can develop a strategy for our further life. To a large extent, a person's constantly tendency to "monitor" the state of safety of the surrounding world remains not only as a "rudiment" of natural experience. Defining a person environment as hostile, favorable, means for a person the opportunity to "save" physical and spiritual forces, to use them in other directions.

The legal order is the phenomenon that marks the "civilization" of the society of human need for security as a natural being in a legal form, which, in fact, is caused by the existence of a social type of human life.

Therefore, the claim that there is a legal order, that it is a reality from the world of our existence, is not in doubt. Another matter is the question of what kind of "appearance", the external manifestation has a legal order, according to which manifestations we can determine its absence or presence, and those 
or other gradations of its partial or sufficient "presence" in public life. Answering these questions, theory of law can not do without addressing the specifics of legal existence.

Law and legal phenomena are a special form of social existence and a specific reality, the unique nature of which acquires specific forms of expression, and therefore - the perception of person.

Unlike the economy, which exists in the form of human activity and social relations, in the process of which human beings are created, or the state, which, in turn, functions in the form of powerful political-territorial institutions, the social "existence" of law is quite peculiar. Law is not one of the objects that can be directly observed, perceived as a specific object. $\mathrm{He}$ has no clearly defined place in the surrounding physical space. All existing attempts to build his philosophical-theoretical model are forced to rely on the existing spiritual and practical experience accumulated over many generations. It gives him the opportunity to build such models. But the basis for the creation of these models must be completely different, independent of the criteria of sensory perception ${ }^{1}$.

With regard to understanding the legal order in modern conditions, this approach is of particular importance, because in the scientific literature devoted to its study, the perception of law and order as a phenomenon of ideal nature dominates mainly as a theoretical construction.

Law and legal phenomena exist in society (in comparison with other institutions of social life) in various "hypostases": in the "form" of officially recognized, formally defined norms, models and standards of behavior (legal norms), in the form of legal consciousness and in the form of acts legal behavior and legal relations. Therefore, it is difficult to agree with the statement that the right exclusively relates to the spiritual life of society ${ }^{2}$. Law also includes a component of "objectivity", and not only one that is related to its "positive" manifestation. Law is a way (form) of material and substantive activity of society, which ensures its self-preservation and development. By the way, it was precisely this combination of spiritual and substantive in legal reality that pointed out B.O. Kostyakovsky, who compared it with the reality of works of sculpture and painting on the one hand, and works of literature and music - on the other, recognizing the law a little closer to the reality of the first kind cultural benefits than the other ${ }^{3}$. With this view of an outstanding domestic jurist echoes and observations of another well-known

\footnotetext{
${ }^{1}$ Бачинин В.А. Философия права и преступления. Харьков: Фолио, 1999. С. 13.

2 Алексеев С. С. Право: азбука - теория - философия: Опыт комплексного исследования. М.: "Статут”, 1999. 226.

${ }^{3}$ Кистяковский Б. А. Социальные науки и право. Очерки по методологии социальных наук и общей теории права. М., 1916. С. 336.
} 
researcher of the problems of philosophy and theory of law. From the point of view of the genesis of the legal nature of man (and at the same time the assertion of the principles of law and law and order in the life of entire nations), the realization of the fact that in the abstractions of law by external conditionality it is the most important and essential in the life of the individual and the whole society plays a decisive role - about freedom, justice, equality, that legal "conventions" are in fact absolutely necessary conditions for a decent human life of everybody and everyone ${ }^{4}$. Therefore, the right, while remaining a phenomenon from the social spiritual world, has at the same time - though not in general, but still in some way has - merged with its external form and hence - a visible and existing character.

For further development of legal order research, development of scientific provisions for its providing in modern conditions, it is important to analyze all forms of manifestation of the legal order in public life, which combine all aspects of its existence as a coherent institutional socio-legal phenomenon, which manifests itself as a legal reality independent element.

The legal order is an integral part, an element of legal reality, which is formed in society as a result of the existence and functioning of law and legal phenomena, social and legal consequences and processes generated by law.

As a phenomenon of legal reality, the legal order is characterized by features inherent in it as a whole internally structured phenomenon.

Like law as a whole, the legal order is a universally recognized fact and an integral part of the official, public and private legal life existing in society, which manifests itself daily in the multifarious circumstances of individuals life, communities and their associations. The legal order, as well as the law as a whole, by the words of I.O. Pokrovsky, is a certain sociopsychological force that regulates people's behavior; it is a certain state of social consciousness and social will, which contains a psychic compulsion to some behavior. As a phenomenon of social psychology, the legal order is thus an undoubted reality, a fact of empirical reality, part of the "world of being" 5

Like law as a whole, the legal order is some extent characterized by such property as coercion: to ensure law and order, to protect it from unlawful encroachment by means of coercive nature.

Like law, the legal order is characterized by a well-established internal structure - its own structure (legal relations, implementation of law, lawful behavior, irregular legal practices, offenses, etc.).

${ }^{4}$ Нерсесянц В. С. Философия права. Учебник для вузов. М.: Издательская группа ИНФРА - М - НОРМА, 1997. С. 42.

${ }^{5}$ Покровский И.А. Основные проблемы гражданского права. М.: Статут. 1998. С. 60. 
Like the law as a whole, the legal order is characterized by objective laws of "existence and development" $"$.

On the other hand, the legal order appears to be a rather peculiar legal reality. The rule of law does not have a documentary likeness characteristic of the positive law components. The substantive, substantive nature of the rule of law comes from the valid actions of social subjects (law-making and implementation of law, enforcement, interpretation of legal orders, etc.), which form a coherent, established legal reality - a certain state of legal ordering of social life. Legal order in this sense emerges as an important sphere of being a society, namely a legal being that interacts with the whole system of social relations and ties, and exists as a certain form of "being of legal matter"7.

The question of how legal is "real" is not only scholastic, scientific. Specific people in their lives encounter specific legal phenomena - get acquainted with the content of the laws, learn about certain facts of a valid character (for example, that a famous Russian businessman bought one of the leading English football clubs "Chelsea", or that the combine Kryvorizhstal sold the state to the foreign owner, or the election of the President of Ukraine), the offenses committed in the society, or the actions of law enforcement agencies, justice, etc. In the course of their own legal practice, people are confronted with the legal behavior of others - managers, officials, colleagues, clients, law enforcement officials, ordinary citizens, offenders. As a result, in the mind of each person a certain relation to the surrounding legal life is formed. It encompasses both the assessment of current legislation, the level of legal protection of a person in this society, and the ability to exercise their legal rights and interests. The perception of a person related to the legal order is largely subjective, depends on the level of legal consciousness of the person, the development of his spiritual and legal world, legal experience, etc.

Law and order is that part of legal reality that cannot be fully understood in its entirety by the consciousness of an individual. The individual perceives certain facts, situations that are fragments of the whole legal order (the socalled "objective" legal order). The whole picture of the public order is reflected in the public consciousness. Features of human consciousness are manifested in the fact that on the basis of fragmentary perception of the surrounding world (a limited number of facts, circumstances and situations, a certain circle of social relations), a person constructs a holistic, generalizing

\footnotetext{
6 Алексеев С. С. Право: азбука - теория - философия: Опыт комплексного исследования. М.: “Статут”, 1999. С. 230.

7 Дражина И. В., Пономаренко Е. В. Правовое освоение действительности в системе юридических категорий. Тюмень, 1995.
} 
picture of the world, its certain image (the mechanism of this process may resemble the reconstruction of the reconstruction found by archaeologists of an individual element of the animal) The "configuration" of an image of the legal order, its substantive content depends on many factors, objective and subjective. But its disadvantages, some deformations of the perception of the legal order, to some extent, are inherent in even the scientific forms of comprehension of the surrounding world.

Thus, the real facts of the legal life of many people, that is, society, are somehow combined into a "general picture", a coherent system of legal existence of a society that constitutes a certain legal system, a social and legal climate of coexistence of people, which is reflected in the public consciousness. Specific people and society as a whole feel the influence of this system on their lives in the way they solve the problems of their legal nature (at work, in relations with the authorities, when applying to law enforcement or justice authorities). For law-abiding citizens, it is also likely to be the target of the offense, and for the offender to be able to avoid being held accountable for such acts.

The reality of the legal order is manifested in the fact that it exists as separate from other phenomena of the material world, along with these phenomena, and in unity with the surrounding world as a whole, there is a legal reality. Like some other legal phenomena that have the character of externally objective entities - institutions, that is, "educated" and "objectified" social phenomena, which as a result of alienation have acquired their own existence and, unlike the individual and social consciousness as such, are embodied in externally delineated, structurally determined, solid and established forms of existence and functioning ${ }^{8}$, law and order as a fixed form of social and legal existence is able to act as a firm and solid foundation or criterion for human behavior.

The legal order has some relation to the "geometry", geography and temporal characteristics of social and legal being, it is a "physical" space in its specific manifestation, one of the dimensions of the space of human being, along with political, economic, religious and other.

\section{Legal climate and investment image of Ukraine}

A specific feature of the legal order in the sphere of investment activity is its formation as the domestic law of the country and international investment law. The situation in the country can either contribute to or oppose the establishment of a favourable legal order (legal framework).

\footnotetext{
8 Алексеев С. С. Право: азбука - теория - философия: Опыт комплексного исследования. М.: “Статут”, 1999. С. 228.
} 
However, experts on international investment law emphasize that in the ratio of national and international investment law, they operate as separate, but mutually agreed interacting legal systems ${ }^{9}$. In accordance with the Vienna Convention on the law of treaties, 1968 years (art. 27), the State may not invoke its internal law, including the Constitution, as a justification for failure to comply with their international obligations ${ }^{10}$.

Sources of international investment law are, inter alia, bilateral international agreement decisions on promotion and protection of investments, for the avoidance of double taxation, trade agreements, agreements on the settlement of economic contracts and industrial with cooperation, as well as multilateral agreements. Among the most important documents of this kind include the Washington Convention on the procedure for settling arguments between the State and the face of another State of the year $1965^{11}$, the Seoul Convention establishing the multilateral investment guarantee agency (MIGA) of the year $1985^{12}$, the agreement on trade-related aspects of foreign investment (TRIM) in force in the $\mathrm{WTO}^{13}$ system, etc.

In accordance with the Seoul convention, the Interstate organization conducting insurance investment risks - the multilateral agency on guarantee investment was established. The investors, who concluded guarantee contracts with the Agency, provided the economic rationale for investment may obtain from the Agency of monetary compensation at insurance event occurrence. After the compensation payment, the Agency has the right to claim these funds from the state-recipient.

In Ukraine there is a block of special normative legal acts, regulating relations in the country. They are the laws of Ukraine "On investment activity"14, "On the regime of foreign investments"15, "On protection of foreign investments" 16 , "On Elimination of discrimination in the taxation of

9 Фархутдинов И. З. Международное инвестиционное право и процесс. Изд-во “Проспект". 2010. С. 82.

10 Действующее международное право. Документы в 2-х томах. Т. 1. Составители Ю. М. Колосов, Э. С. Кривчикова. М.: Междун. отношения. 2002. С. 352.

11 Конвенція про порядок вирішення інвестиційних спорів між державами та іноземними особами. URL: https://zakon.rada.gov.ua/laws/show/995_060

${ }^{12}$ Сеульська конвенція 1985p. про заснування багатостороннього агентства 3 гарантій інвестицій. URL: https://zakon.rada.gov.ua/laws/show/995_268.

${ }^{13}$ Угода про пов'язані з торгівлею інвестиційні заходи. URL: https://zakon5.rada.gov.ua/ laws/show/981_009/

14 Закон України “Про інвестиційну діяльність”. Відомості Верховної Ради Украӥни (ВВP). 1991, N 47, ст. 646.

15 Закон України "Про режим іноземного інвестування". Відомості Верховної Ради Украӥни (ВВР). 1996. № 19. Ст. 80.

16 Закон України "Про захист іноземних інвестицій на Україні". Відомості Верховної Ради Украӥни (ВВР). 1991, N 46, ст. 616. 
business entities created using the property and assets of national origin" ${ }^{17}$ as well as the Economic Code of Ukraine ${ }^{18}$. Ukraine ratified the Convention on the procedure for settlement of investment disputes between States and foreign citizens (March 16, 2000) ${ }^{19}$.

These are fundamental legal acts, which are designed to form the basis of the legal order in the field of investment activity, and, therefore, are able to influence the investment climate and investment attractiveness of our country in the eyes of foreign investors. Among the factors that also have a positive effect on the state of the legal order; legal guarantees for foreign investors in Ukraine take an important place.

Among the most important guarantees that Ukrainian legislation establishes with respect to foreign investors are the guarantee of stability of the conditions for carrying out investment activities, respect for the rights and legitimate interests of its subjects. State bodies and their officials do not have the right to interfere in the activities of subjects of investment activities, except when such interference is allowed by current legislation and is carried out within the competence of these bodies and officials ${ }^{20}$. Article 397 of the Economic Code of Ukraine, among the most important guarantees, also provides for compensation and compensation for losses to foreign investors ${ }^{21}$. Compensation and reimbursement to foreign investors of losses caused to them as a result of actions, inactivity, or improper fulfillment by the state authorities of Ukraine or their officials of obligations regarding a foreign investor or an enterprise with foreign investments includes not only direct damage, but also lost profits, as well as moral damage (damage business reputation).

At the same time, the complex of legal guarantees stipulated by the legislation of Ukraine regarding foreign investments implies that the Ukrainian legislation imposes certain requirements on the actions of a foreign investor.

First of all, these are the requirements of doing business in Ukraine legally, in full compliance with Ukrainian legislation. In 2016, in order to

17 Закон України “Про усунення дискримінації в оподаткуванні суб'єктів господарювання, створених з використанням майна та коштів вітчизняного походження". Відомості Верховної Ради Украӥни (ВВР). 2000. № 12. Ст. 97.

${ }_{18}$ Господарський Кодекс України. Відомості Верховної Ради Украӥни (ВВР). 2003. № 18. № 19-20. № 21-22. Ст. 144.

19 Конвенція про порядок вирішення інвестиційних спорів між державами та іноземними особами. URL: https://zakon.rada.gov.ua/laws/show/995_060

20 Закон України Про інвестиційну діяльність. URL: https://zakon.rada.gov.ua/ laws/show/1560-12.

${ }^{21}$ Господарський Кодекс України. Відомості Верховної Ради України (ВВР). 2003. № 18. № 19-20. № 21-22. Ст. 144. 
maximally simplify the procedure for attracting investments by introducing the declarative principle of their state accounting, Article 395 of the Economic Code was abolished, which required the registration of foreign investments by local state administrations, as well as the relevant provisions of other legal acts. The elimination of administrative control (and the corruption pressure on foreign investors) removed unjustified obstacles to business.

Nevertheless, the fact of foreign investments is recorded in the statutory documents of economic entities and is entered into the Unified State Register of legal and natural persons-entrepreneurs. The subsequent operation of the business in accordance with the requirements of the law (for example, compliance with labor laws in relation to employees, payment of taxes, etc.) is also assumed.

The question of which institutions of justice are really designed to protect a foreign investor is also very important. Ukraine supports the jurisdiction of foreign institutions operating in this area. Thus, investment disputes may be considered by arbitration provided for by the Arbitration Rules of the United Nations Commission on International Trade Law. Investors are entitled to apply for the protection of their rights to the International Center for the Regulation of Investment Disputes, established in accordance with the Convention on the procedure for resolving investment disputes between states and foreign citizens ${ }^{22}$.

Such cases can also be considered in the European Court of Human Rights, and in the state courts of Ukraine.

It should be noted the close relationship between the legal order, the investment climate, and the investment attractiveness of the country. The categories "investment attractiveness" and "investment climate" are interpreted differently in economic research. Some researchers identify them; others see significant differences between them ${ }^{23}$. Without going into details of expert discussions, it should be noted that each of these categories has its own meaning, although in a certain part they intersect and complement each other. At the same time, investment attractiveness is a peculiar result of the investment climate and legal order.

As in any case of making decisions on the allocation of capital, the entrepreneur is guided by two main considerations: 1) the investment image of the target country and 2) the objective characteristics of the investment climate in it. Each of these phenomena has its own nature, its own mode of

22Конвенція про порядок вирішення інвестиційних спорів між державами та іноземними особами. URL: https://zakon.rada.gov.ua/laws/show/995_060

${ }^{23}$ Курпаяниди К.И. Актуальные вопросы оценки инвестиционной привлекательности и факторы активизации инвестиционных потоков. Экономика, предпринимательство $u$ право. 2011. № 9. С. 11-18. 
existence, but they are closely linked, in one way or another, correlating each other.

The investment image is formed by business entities as an informal conceptual characteristic of the business environment in the country, which, above all, characterize economic efficiency in the most general characteristics of the possible financial effect from an investment project. The investment image of the country is shaped primarily by informal channels, business communications, the Internet environment, an independent press, and so on. What is not less important is the perception by the subject of the decision to invest in a given country of the decisive relationship between the risks and the financial efficiency of this project. And here begins the peculiarities of individual perception by a potential investor of many factors that are important in order to induce his decision in favor of this project. The investment image has the form of a kind of "matryoshka" in which the investment image of the country is consistently located, and further in it is the investment image of the region, city (industry), and particular enterprise. A special component of this image is information disseminated through unofficial channels about the political context and legal security of a business in Ukraine. If the sum of positive characteristics of a particular subject of decision making outweighs the conditional risks, this project can take place. In the case of the analyzed issues of attracting foreign investment in Ukraine, given the mentality and peculiarities of foreign psychology, it is the negative image of Ukraine in recent years that has been the main factor deterring foreign investors from coming to Ukraine. It should be recognized that in 2010-2013, by "joint actions" of the authorities and criminals, the investment image of Ukraine suffered significant image damage, which is gradually but steadily being overcome in our time. The main trend in this is the promotion of our country towards the introduction of European standards and business guarantees. This is not to say that this promotion is easy and smooth. But there is a feeling that the political will of the current and potential power is committed (more precisely, doomed) to follow this vector. And this is probably our best "informal" message to foreign entrepreneurs who are closely eyeing Ukraine.

The objective characteristic of the investment climate in the economic doctrine is called "investment attractiveness". In the most general form, investment attractiveness is a set of characteristics that allow a potential investor to assess how much an investment object (enterprise, industry, region, country) is more attractive than others for the investment of funds required for this investment project.

Among the factors that businessmen undoubtedly weigh, considering Ukraine as a country of location, legal (legal) conditions and guarantees of business functioning in our country are important. 
Regarding the state and trends that characterize the legal sphere, "responsible" for the investment business in Ukraine, there is a wide range of opinions - from cardinally negative to just as radically positive on the part of narrowly politically motivated characteristics. I will not argue that "the truth is, as always, in the middle" - we will try to analyze the facts.

The Law of Ukraine "On Amendments to Certain Legislative Acts of Ukraine regarding the simplification of business conditions (deregulation) and attracting investments by issuers of securities" ${ }^{24}$, adopted in 2018 , is intended to drastically improve the situation in limiting negative bureaucratic influence on business.

Another effective factor in protecting business in Ukraine should be the institution of a business ombudsman, a draft law introducing which is under consideration by the Ukrainian parliament.

An important component of the approval of European business standards in Ukraine is the policy of improving the financial sector and reforming the banking system. Since 2015, measures have been taken to remove insolvent banks from the market to clean up the banking system from institutions that had systemic risks, which should lead to a return of confidence in the national banking system, and as a result, to resume the proper level of lending, which is more necessary than ever for accelerated development business.

For businessmen information on the gradual improvement of the conditions for doing business in the field of agricultural production in Ukraine may be interesting. The most common form of agribusiness in Ukraine, acceptable to foreign investors, are business partnerships, which may be national, foreign, or with foreign investment.

One of the landmark legal tools that have emerged in the arsenal of business and investment protection in recent years in Ukraine is a production claim introduced by the Verkhovna Rada of Ukraine and signed by the President of Ukraine - the Law of Ukraine "On Amendments to Some Legislative Acts of Ukraine Concerning the Protection of Investors' Rights" No. 289 - VIII of April 7, 2015, which entered into force on May 1, $2015^{25}$. A production claim is a claim for damages filed by the participants of the economic company in order to declare the actions of the officials of this company illegal, which is the formal basis for compensation for the damage caused. The plaintiff in such cases is a business entity, in whose interests a claim is filed for damages caused to this company by the actions (inaction) of its official.

24 Закон України "Про внесення змін до деяких законодавчих актів України щодо спрощення ведення бізнесу та залучення інвестицій емітентами цінних паперів". Відомості Верховної Ради (ВВР). 2018. № 6-7. Ст. 38.

${ }^{25}$ Відомості Верховної Ради (ВВР). 2015. № 25. Ст. 188. 
The right to submit a claim to the court on behalf of the economic company, as well as a statement on the implementation of the representative of the claimant was granted to the participant (shareholder) of this company, who jointly owns 10 or more percent of the authorized capital (ordinary shares) of the company. These persons will have the status of a representative of the relevant company.

Such a representative can carry out the representation of the company personally (if it is an individual), through its bodies (if it is a legal entity), government bodies, authorities of the Autonomous Republic of Crimea, local governments (if it is a state, Autonomous Republic of Crimea, territorial community), through its other representatives. At the same time, a participant (shareholder), who collectively owns 10 or more percent of the authorized capital (ordinary shares) of a company, may carry out the company's representation through one of the participants (shareholders), or jointly authorize another person, as provided for by the new, 8 article 28 part Economic Procedural Code of Ukraine ${ }^{26}$.

As it is known, one of the most important barriers that recently kept Western investors from coming to Ukraine was the lack of real independence of courts from the political and administrative influence of the legislative and executive authorities, their corruption, as well as the unacceptable corruption of the police, customs, fiscal authorities, the licensing system and others.

Among the measures that, in the opinion of the authorities in Ukraine, should resolutely contribute to the improvement of the judicial system are the adoption of the Law of Ukraine of June 2, 2016 № 1402-VIII "On the judicial system and the status of judges" 27 . Fundamental changes in the judicial system and the legal status of judges demanded changes to the Basic Law of the country - the Constitution of Ukraine, which was implemented by the Law of Ukraine dated June 2, 2016 No. 1401-VIII "On Amendments to the Constitution of Ukraine (on Justice)" 28 .

These legislative innovations are reformist and very ambitious, their effectiveness and real results (as well as shortcomings) can be fully manifested in the medium and long term. Experts of the judicial reform proceed from the fact that these are her first steps, which will require, on the one hand, a steady adherence to the laws already adopted, and on the other, the next steps to promote the reform through legislative means.

The main component of this stage of judicial reform, provided for by these laws, is the creation of a new judicial system for Ukraine, including local courts, courts of appeal, and the Supreme Court of Ukraine. Such a system of justice is

\footnotetext{
${ }^{26}$ Відомості Верховної Ради України (ВВР), 1992, № 6, Ст. 56.

${ }^{27}$ Відомості Верховної Ради (ВВР). 2016. № 31. Ст. 545.

${ }^{28}$ Відомості Верховної Ради (ВВР), 2016, № 28, Ст. 532.
} 
intended (and, as the first results and opinions of experts already show, positive changes take place) to make the court open, transparent, accessible to the ordinary citizen. So, at present, any person online can get information about the composition of the court, the cases that are considered there, the decisions taken. The possibilities for citizens to attend court sessions, audio and photo fixing, video recording with a portable camera are also much democratized.

Very interesting from the standpoint of theoretical jurisprudence, is the legislative initiative to establish in the practice of Ukrainian justice the principle of the rule of law, designed to ensure the fairness of the decisions taken by the courts even in conditions of imperfection and inconsistency of the current legislation. This will be facilitated by the institution of a case (exemplary) case / This means that the decision made by the Supreme Court in a particular case will be an example (precedent) for other courts when considering other similar cases, which will prevent clearly illegal and unfair decisions, make decisions more open and predictable.

Or, for example, the new procedure for filling the posts of the Supreme Court, which until recently was closed, backstage, protectionist and corruption. Now, anyone who meets the formal requirements can take part in an open competition, and win - subject to successful passing of exams, tests, including psychological ones. Obviously, exam and test programs need to be improved in order to achieve $100 \%$ accuracy in the selection of applicants, but the existing practice of applying the new procedure indicates a move in the right direction.

Undoubtedly, the reform is not proceeding smoothly, citizens and society did not see rapid qualitative changes in the functioning of justice, even on the contrary, due to the dismissal of 2.5 thousand judges out of 8 thousand, the terms of consideration of cases increased, the efficiency of the courts decreased. We hope temporarily, otherwise people will be disappointed in this reform. In order to approve the meanings and tasks of judicial reform, new rules for re-evaluating judges, such new institutions as the High Council of Justice, the High Anti-Corruption Court and the High Court of Intellectual Property should be fully earned.

An important factor in improving the legal climate in the country is effective law enforcement. To this end, in Ukraine, one of the first, police reform was initiated (one of the reasons for the initiation of which was that the level of public confidence in the Ukrainian police at that time fell to 5\%). The fact that the situation has changed for the better, most experts say, is also considered by many citizens. According to the results of 2017, according to the Minister of Internal Affairs of Ukraine A. Avakov, the level of confidence in the new police is $40,7 \%{ }^{29}$. The lag in updating the police from the

29 URL: https://censor.net.ua/ua/news/3046947/riven_doviry_do_slujb_mvs_znachno_ vyris_avakov 
expectations of society is largely due to the inertia of the police system, the difficulties of recruiting new, modern police personnel (as the head of the National Police of Ukraine, Sergey Kniazev, admits, out of 132,000 police officers currently, only 18,000 are employed after 2015).

It should be recognized that the implementation of the reform of the law enforcement system is a very complex, responsible and sensitive process for the population. Therefore, there is first carried out the experimental implementation of innovations that are tested by national practice, and only after that they can be introduced throughout the country. So, now in the Kherson and Dnepropetrovsk regions an experiment is being conducted on the introduction of the custody records system, that is, the electronic registration system of the detainees, in which all actions concerning the detainee are recorded from the time it enters the temporary detention center. As you know, this is a British model, it works very effectively in its homeland, its strengths are that everything is controlled here, there are no moments when human rights violations are possible, because it fixes who performs certain actions. It is also recorded that the face is under video surveillance. The introduction of this practice requires significant financial resources for the acquisition of technical equipment and personnel training, but experts consider it very necessary.

The implementation of the service approach to its development is considered to be very promising in the transformation of the Ukrainian police. Some experts believe that the police should become a service. Service centers established in many regions that provide administrative services are already working in this direction. As Denis Monastyrsky, an expert of the program of reforming law enforcement and judicial systems, notes: “... for the second year the police have mastered the Scandinavian experience in working with mass meetings and meetings. I see a positive trend in the fact that we have a negotiating police; it is also called the "police of dialogue". In many large cities, they go to rallies, without weapons, even without uniform, communicate with the protesters, helping them to realize their right. And this is an element of the philosophy that the police should be a service ..."30.

Another important area of police reform in Ukraine is the evaluation of its activities by the level of public confidence. As envisaged by the Order of the Ministry of Internal Affairs of November 9, 2018 No. 900, registered by the Ministry of Justice of Ukraine on November 29, 2018 31 , an assessment of the level of public confidence in the National Police is carried out using indicators such as crime, police performance and police failures, as well as police and

30 Нова поліція і старі проблеми: що не так 3 правоохоронною реформою. URL: https://ukr.segodnya.ua/ukraine/novaya-policiya-i-starye-problemy-chto-ne-tak-s-pravoohranitelnoyreformoy-1161735.html

${ }^{31}$ URL: https://ips.ligazakon.net/document/view/RE32810?an=1 
public relations. The procedure for assessing the level of public confidence in the National Police is provided for by the Resolution of the Cabinet of Ministers of Ukraine of February 2, 2018 No. 58 "On Approving the Procedure for Assessing the Level of Public Confidence in the National Police of Ukraine" 32 . It seems that in this way the "feedback" of the police with the population, which is so necessary in law enforcement, will be strengthened, which should contribute to the improvement of its activities.

Important for foreign investors in such a large, on a European scale, country like Ukraine, are also regional conditions for doing business and supporting investment activities. Local state administrations (district, oblast) are empowered to develop programs for the socio-economic development of the respective territories, make proposals for the creation of free economic zones, facilitate the creation of enterprises with foreign investments, carry out investment management, including with the participation of foreign investors, submit for discussion relevant bodies of proposals for attracting foreign investment in the economic development of relevant administrative-territorial units. Also, local governments organize events aimed at promoting the investment attractiveness of the region.

\section{CONCLUSIONS}

Attraction of foreign investments into the economy is reasonably considered to be one of the most powerful resources for its development, so it is extremely important for Ukraine. The attractiveness of the country for foreign investment is determined by a number of factors, one of the most significant is modern, encouraging inward investment legislation, relevant law practice functioning of the economy and business, an adequate level of protection for business institutions of justice and law enforcement systems, tolerant attitude to business, including a foreign one. In this sense, it is a legal procedure in the area of investment and enterprise development that business is particularly sensitive concerning the country, the economy of which is planned to invest into.

Legal order is an integral indicator of the legal life quality of the state and society-legislation, its ability to protect rights and freedoms, property, economy, entrepreneurs, foreign investment among other things, against undue influence (crime, racketeering, corruption, arbitrary political decisions, populism), functioning of state institutions in strict accordance with the law, the effective functioning of the judicial system under the rule of law, as well as sustainable respect for law in society and its proper implementation by citizens, organizations and institutions.

\footnotetext{
${ }^{32}$ URL: https://ips.ligazakon.net/document/view/KP180058?an=1
} 


\section{SUMMARY}

In general, the material cited here shows that Ukraine, having embarked on the implementation of European business standards, consistently establishes them in national legislation, approves the practice of its precise and strict observance, and provides the necessary state guarantees. This creates positive conditions for strengthening the legal order in the sphere of economic activity and business, forming the image of Ukraine as an attractive country for foreign investment.

\section{REFERENCES}

1. Бачинин В.А. Философия права и преступления. Харьков: Фолио, 1999. $607 \mathrm{c}$.

2. Алексеев С.С. Право: азбука - теория - философия: Опыт комплексного исследования. М.: “Статут”, 1999. 710 с.

3. Кистяковский Б.А. Социальные науки и право. Очерки по методологии социальных наук и общей теории права. М., 1916. С. 336.

4. Нерсесянц В.С. Философия права. Учебник для вузов. М.:Издательская группа ИНФРА - М - НОРМА, 1997. 652 с.

5. Покровский И.А. Основные проблемы гражданского права. М.: Статут. 1998. 234 c.

6. Дражина И.В., Пономаренко Е.В. Правовое освоение действительности в системе юридических категорий. Тюмень, 1995. $144 \mathrm{c}$.

7. Фархутдинов И.З. Международное инвестиционное право и процесс. М.: Изд-во “Проспект”. 2010. 683 с.

8. Действующее международное право. Документы в 2-х томах. Т. 1. Составители Ю.М. Колосов, Э.С. Кривчикова. М.: Междун. отношения. 2002. $768 \mathrm{c}$.

9. Конвенція про порядок вирішення інвестиційних спорів між державами та іноземними особами. URL: https://zakon.rada.gov.ua/ laws/show/995_060

10. Сеульська конвенція 1985 р. про заснування багатостороннього агентства 3 гарантій інвестицій. URL: https://zakon.rada.gov.ua/ laws/show/995_268

11. Угода про пов'язані 3 торгівлею інвестиційні заходи. URL: https://zakon5.rada.gov.ua/laws/show/981_009/

12. Про інвестиційну діяльність: Закон України від 18 вересня 1991 p. № 1560-XII. Відомості Верховної Ради України. 1991, N 47, ст. 646.

13. Про режим іноземного інвестування: Закон України від 19 березня 1996 р. № 93/96-ВР. Відомості Верховної Ради Украӥни. 1996, N 19, ст. 80 . 
14. Про захист іноземних інвестицій в Україні: Закон України від 10 вересня 1991 р. № 1540а-XII. Відомості Верховної Ради України. 1991, N 46, ст. 616.

15.Про усунення дискримінації в оподаткуванні суб'єктів господарювання, створених 3 використанням майна та коштів вітчизняного походження: Закон України від 17 лютого 2000 p. Відомості Верховної Ради України. 2000, № 12, ст. 97.

16. Господарський Кодекс України. Відомості Верховної Ради Украӥни. 2003, № 18, № 19-20, № 21-22, ст. 144.

17. Курпаяниди К.И. Актуальные вопросы оценки инвестиционной привлекательности и факторы активизации инвестиционных потоков. Экономика, предпринимательство и право. 2011. № 9. С. 11-18.

18. Про внесення змін до деяких законодавчих актів України щодо спрощення ведення бізнесу та залучення інвестицій емітентами цінних паперів: Закон України від 16 листопада 2017 р. № 2210-VIII. Вiдомості Верховної Ради. 2018. № 6-7, ст. 38.

19. Про внесення змін до деяких законодавчих актів України щодо захисту прав інвесторів: Закон України від 7 квітня 2015 р. № 289-VIII. Відомості Верховної Ради. 2015, № 25, ст. 188.

20. Господарський процесуальний кодекс України. Вiдомості Верховної Ради України. 1992. № 6. ст. 56.

21. Про судоустрій і статус суддів: Закон України від 2 червня 2016 р. № 1402-VIII. Відомості Верховної Ради. 2016. № 31, ст. 545.

22. Про внесення змін до Конституції України (щодо правосуддя): Закон України від 2 лютого 2016 р. № 1401-VIII. Відомості Верховної Ради. 2016. № 28, ст. 532.

23. Уровень доверия к службам МВД значительно вырос. URL: https://censor.net.ua/ua/news/3046947/riven_doviry_do_slujb_mvs_znachno_ vyris_avakov.

24. Нова поліція і старі проблеми: що не так 3 правоохоронною реформою. URL: https://ukr.segodnya.ua/ukraine/novaya-policiya-i-staryeproblemy-chto-ne-tak-spravoohranitelnoyreformoy1161735.html.

Information about the author:

Kryzhanovskii A. F., Doctor of Legal Sciences, Professor, Head of State Law Disciplines Department, International Humanities University 33, Fontanska Road str., Odessa, 65009, Ukraine 


\section{JURIDICAL ACTIVITY AS A SPECIAL AREA FOR THE APPLICATION OF JURIDICAL ALGORITHMS}

Manko D. G.

\section{INTRODUCTION}

Juridical activity is a special type of social practice. It is related to such principles as legal education, analytical thinking, knowledge of current legislation, understanding of procedural and processual features of legal proceedings.

The effectiveness of such activity is based on the knowledge of the conditions of establishing the factual circumstances of the case and their proper registration, high legal qualification and the ability of legal construction, taking into account the understanding of the rules, methods, and principles of technologies for solving a legal case and the creation of legal acts.

There is no doubt that juridical activity is a special kind of legal activity. The legal activity of legal entities is manifested in the form of legally significant actions (acts or inactions).

Taking into account the fact that a system of specially authorized bodies and, accordingly, targeted logistic is necessary for the implementation of the juridical activity, the main form of such activity is the legal process. It is the main form, though not the only one since separate procedures are also carried out within the framework of juridical activity.

Legal procedure, for its part, is a form of implementation of legally significant actions (which are primarily one-off). Report submission, signing of the contract and many other legal procedures do not require "special" powers, the system of special bodies, and accordingly the logistical support from the subject of their implementation.

However, the correlation of categories of juridical activity and legally significant actions indicate a wider scope of the latter's logical content. Juridical activity is a specific form of legal action carried out by specially authorized entities.

\section{Juridical activity in the system of social activities}

In his turn, V.I. Chervonyuk states that "legal activity is a social quality that stems from social and legal principles, needs and interests of people, and is characterized by the actual implementation of legal requirements, principles, and regulations. Legal activity characterizes the life of law at the stage when its prescriptions and principles become effective. Therefore, 
simplifying, we can say that law in action tends to legal activity, the content of which is any manifestation of law in public life. Legal activity thereby reflects the interaction between society and the individual that is provided by the law. Consequently, the content of legal activity covers: 1) a set of personal social and legal qualities of the subjects which determine the possibility of their participation in the legal life (internal aspect); 2) the very real life of the individual, the community of people in its various quantitative and qualitative characteristics in the scope of law (external aspect) ${ }^{1}$.

According to I.M. Zaitsev, "juridical activity is characterized by a certain order, which must be - and in most cases is - optimal for the implementation of certain legally significant actions. It is established by the relevant regulations. For instance, the rules and regulations of representative bodies of state power, the adoption of legislative acts, the elections, the defense of dissertations, the procedure for service of a housing warrant, inheritance, etc. The optimum order contains a program of juridical activity, it is of indicative importance for the achievement of a particular legal goal, thereby increasing the efficiency of legal regulation of juridical activity and guaranteeing its legitimacy and effectiveness.Violation of the order is an offence, and in some cases, the results of such unlawful activities are legally void (invalid)"2.

However, legally significant actions can be implemented in the form of inaction. So, for example, compliance with the provisions of regulations that prohibit certain actions.

Therefore, it should be taken into consideration that the legally significant activity of legal entities can be manifested: 1) in the form of juridical activity (carried out in the form of legal process and legal procedures), 2) in the form of performing separate legal actions (carried out in the form of legal procedures), 3) in the form of legally significant inaction a) is carried out in the form of a legal algorithm for compliance with the prohibition, b) is carried out in the form of awareness of a legally significant prescription (understanding of norms-definitions, notions, regulations, principles).

Juridical activity is a reflection of the features of law-making and implementation of legal norms that are carried out in accordance with established rules, as well as: legal culture, legal technology and legal education in a particular country. This necessitates an analysis of the legal system in more detail and the separation of its constituent elements.

\footnotetext{
1 Элементарные начала общей теории права: учеб. пособие для вузов / под общей ред. д-ра юрид. наук, проф. В. И. Червонюка. Право и закон, М.: Колос С, 2003. С. 54.

2 Зайцев И. М. Понятие и содержание юридического процесса // Теория государства и права. Курс лекций. Под ред Матузова Н. И., Малько А. В. 2-е изд., перераб. и доп. - М.: Юристь, 2001. С. 442.
} 
According to N.M. Onishchenko, the structure of the legal system includes the following principal elements: "1) law as a set of norms created and protected by the state; 2) legislation as a form of expression of these norms (regulations); 3) legal requirements; 4) legal institutions implementing the legal policy of the state; 5) judicial and other legal practice; 6) the mechanism of legal regulation; 6) the implementation process (including acts of application and interpretation); 8) rights, freedoms, and obligations of citizens (law in a subjective sense); 9) legal activity; 10) systems of legal relations formed in society; 11) law and order; 12) legal ideology (justice, legal doctrines, theories, legal culture, etc.); 13) subjects of law (individual and collective); 14) systematic links that ensure the unity, integrity, and stability of the system; 15) other legal phenomena (legal liability, legal personality, legal status, regime, guarantees, legitimate interests, etc.)"3.

Along with the above-mentioned, there is a scientific position according to which "the legal system consists of the following components: 1) institutional - subjective composition (subjects of law) as a system-forming factor of the whole legal system; 2) normative (regulatory) - legal norms and principles governing the relations between the subjects of law, objectified and systematized in normative legal acts; 3 ) ideological - the legal understanding of each person, society, sense of justice, legal culture, the opportunity to evaluate the legal existence and to choose a possible variant of behavior lawful or unlawful; 4) functional (processual) - law-making, lawenforcement, law-application, legal activity, legal education, legal relations, legal practice; 5) communicative - integrative (aggregate) connections of all subsystems of the legal system of society, which generally determine the effectiveness of legal regulation, legality, law, and order ${ }^{4}$.

The last of these stances of understanding of the legal system is seen as more clearly reflecting the types and interconnections of its components, and therefore taken as a basis in our research. It is within the functional component of the legal system that we can identify the initial features of juridical activity.

However, it should be considered that the notion of juridical activity, which has recently received considerable attention, includes many positions of understanding, both with regard to its nature and its types. These issues make it difficult to develop a unified approach to the definition of juridical activity and to establish its place in the legal system of Ukraine. Juridical activity is identified with legal behavior, legal practice, activity, legal forms of state activity, legal process, legal relations, and other related phenomena.

\footnotetext{
${ }^{3}$ Оніщенко Н. М. Правова система: проблеми теорії / Оніщенко Н М. К.: Ін-т держави і права ім. В. М. Корецького НАН України, 2002. С. 18.

Правові системи сучасності. Глобалізація. Демократизм. Розвиток / В. С. Журавський, О.В.Зайчук, О. Л. Копиленко, Н. М. Оніщенко; за заг. ред. В.С. Журавського. К. : Юрінком Інтер, 2003. С. 57.
} 
Given the diversity of approaches to understanding juridical activity as a legal phenomenon in the context of research objectives, it is advisable to consider the law conditionality of juridical activity.

A characteristic feature of juridical activity as an element of any legal system is the fact, that its formation takes place under the influence of the aggregate of ideological, regulatory, economic and other factors.

In this regard, O.V. Minchenko points out that "juridical activity and law act as two sides of the existence of legal reality - theory (doctrine) and practice. The law defines the basic parameters of legal activity - functions, purpose, tasks, as well as the main objects of influence. Thus, in their relation law and juridical activity interact as cause and effect"5.

Juridical activity as a complex and multifunctional legal phenomenon can be studied and defined in different contexts or systems of "coordinates" of scientific research. The analysis of approaches to the interpretation of legal activity in the scientific literature ${ }^{6}$ allows to distinguish the main of them:

- juridical activity as a type of social activity in which it is considered in comparison with other types of social activity - such as economic activity, political activity, pedagogical activity, etc., but juridical activity is identical to legal activity since it can be performed by any subject of law as well as economic activity is carried out not only by economists and political activity not only by politicians;

- juridical activity as a type of legal activity, within which the activity of lawyers is already distinguished, unlike in other types of legal activity, that can be carried out and is carried out by "non-lawyers", but the understanding of juridical activity is usually limited to its legal properties, and to some extent, these properties are lost as a form of social activity (that is, social characteristics that are legal but not reducible to them ${ }^{7}$;

- juridical activity as a legal practice. The limitations of such a scientific analysis lie, first, in its orientation solely to legal practical activity, and thus its removal beyond the scope of the study of juridical scientific and juridical educational activity, and, secondly, its identification with legal practical activity $^{8}$

${ }^{5}$ Мінченко О. В. Особливості здійснення юридичної діяльності в умовах германської правової сім'ї. С. 67.

${ }^{6}$ Жалинский А. Э. Профессиональная деятельность юриста. Введение в специальность. Учебное пособие / А. Э. Жалинский. М. : Издательство БЕК, 1997. С. 6.

${ }^{7}$ Оніщенко Н. М. Правова система: проблеми теорії: Монографія / Н. М. Оніщенко. К. : Ін-т держави і права ім. В. М. Корецького НАН України, 2002. С. 71.

8 Леушин В. И. Соотношение правовой практики и юридической деятельности / В. И. Леушин // Юридическая деятельность: сущность, структура, виды: Сб. науч. тр. Ярославль : Яр. ГУ, 1989. С. 47. 
- juridical activity as an element of the legal system. At the same time, attention is paid to its systematicity, place, role, purpose in the legal system, relations with other elements of the legal system, etc. However, this approach, distinguishing the systematicity of legal reality and the juridical activity itself as the dominant of the scientific search, still reduces juridical activity to legal activity ${ }^{9}$;

- juridical activity as a type of professional activity, the peculiarity of which is its implementation on a professional basis in the legal sphere of public life.

Such an aspect of the study on juridical activity makes it possible to consider it as certain integrity in the unity of social and legal properties ${ }^{10}$.

Thus, pluralism of scientific approaches to the definition of the features of juridical activity, unlike monism (one-dimensionality), provides the comprehensiveness of the study, but the most appropriate for use in this research is the interpretation of juridical activity as a professional activity in the field of law or professional legal activity of lawyers since it is the professionalism of juridical activity that allows to consider it in the unity of social and legal features of a particular profession, therefore, as an element of not only legal, but also economic, political, cultural, social, state, non-state (civil society) and other spheres of public life, or the activity of lawyers as professional legal scholars (practitioners, scientists, educators) in their social properties, that is, in a comprehensive way.

In his turn, D.O. Tikhomirov, analyzing approaches to understanding the juridical activity, notes that "on the basis of those basic provisions concerning juridical activity as a type of social activity, which reflects its general and peculiar properties in relation to social activity and its other types, we should distinguish the following characteristics:

- social activity is carried out in society, and social phenomena are its conditions, forms, means, purpose, results, etc.;

- social activity emerges, exists and evolves in society and is to meet relevant needs;

- the main components of social activity are subjects, objects, subjective and objective parties, or subject - object - purpose - forms, methods, means the result and the actual process of activity;

- by the criterion of spheres of social life, it is divided into economic, political, social (in the narrow sense), spiritual, as well as state and non-state

\footnotetext{
${ }^{9}$ Оніщенко Н. М. Правова система: проблеми теорії: Монографія / Н. М. Оніщенко. К. : Ін-т держави і права ім. В. М. Корецького НАН України, 2002. С. 124.

${ }^{10}$ Гусарєв С. Д. Юридична діяльність: методологічні та теоретичні аспекти: автореф. дис. на здобуття наук. ступеня д-ра юрид. наук: спец. 12.00.01 “Теорія та історія держави і права; історія політичних і правових вчень” / С. Д. Гусарєв. К., 2007. С. 15.
} 
(public), legal and non-legal; by the levels of existence of its subjects activity of society, social collective, individual; by professional implementation - professional and non-professional"11.

In his time, V.M. Kartashov, understood juridical activity as "such mediated professional, labor, the state-power activity of competent bodies in making legal decisions, aimed for performing public functions and tasks (creation of laws, administration of justice, the concretization of law, etc.) and satisfaction of social, group and individual interests ${ }^{12}$. This position, on the one hand, reflects a close relationship with the state, juridical activity is the prerogative of state bodies, so the basic properties of state sovereignty are manifested in this activity, and on the other hand, it significantly reduces the importance of its non-state forms as institutions of civil society.

The work of V.I. Leushin is a certain development of the ideas of V.M. Kartashov. Analyzing juridical activity, Leushin refers to its subjects legislators, competent authorities and their officials who make lawenforcement decisions; bearers of subjective rights and responsibilities, and equates juridical activity with legal practice, legal activity, although puts emphasis on its professional character ${ }^{13}$.

Similar approaches to distinguishing the properties of juridical activity have been applied in the works of other authors, and therefore its peculiar features - legality and professionalism, unity of juridical practical, scientific and educational activity - have remained unaddressed. At the same time, the necessity of this is emphasized by N.M. Onishchenko, who underlines the importance of the conditions of carrying out the professional juridical activity: social environment, legal elements, a system of resource, personnel, information, technical conditions, financial support, and others ${ }^{14}$. O.E. Zhalinsky singles out professionalism as a basic feature of juridical activity ${ }^{15}$.

O.F. Skakun is also prone to this approach considering it necessary to take into account the features of legal practical, scientific or educational activities and their interaction. According to the opinion of O.F. Skakun, juridical

11 Тихомиров Д. О. Юридична діяльність в англо-американській правовій сім’ї (теоретико-правові аспекти). С. 44.

${ }_{12}$ Карташов В. Н. Юридическая деятельность: понятие, структура, ценность. Саратов: Изд-во Саратовского ун-та, 1989. С. 78.

13 Леушин В. И. Юридическая практика в социалистическом обществе: (Гносеологический и специально-юридический аспект): Автореф. дис... д-ра юрид. наук : 12.00 .01 / Свердловск. юрид. ин-т им. Р. А. Руденко. Свердловск, 1990. С. 22.

14 Жалинский А.Э. Профессиональная деятельность юриста. Введение в специальность. Учебное пособие / А. Э. Жалинский. М. : Издательство БЕК, 1997. С. 3.

15 Жалинский А. Э. Профессиональная деятельность юриста. Введение в специальность. Учебное пособие / А. Э. Жалинский. М. : Издательство БЕК, 1997. С. 3. 
activity should be seen as a juridical practice that embraces all areas of activity of lawyers, as legal scholars and is a key element of the content of juridical practice. The author concludes that, in addition to direct juridical practice, the activity of a lawyer also lies in scientific and educational forms. Moreover, the cited work convincingly substantiates the possibility and necessity of interaction of these forms of juridical activity ${ }^{16}$.

In this context, it is necessary to mention the contemporary and comprehensive study of juridical activity carried out by S.D. Gusarev. Summarizing the various positions on the understanding of the nature of juridical activity, the scientist distinguishes its following features:

- it is social in its content and is carried out in the field of law as a legal activity aimed at organizing the activities of other subjects of law, and its purpose is to regulate and harmonize social relations;

- unlike other types of legal activity, juridical activity is characterized, first of all, by professionalism and legality, as its peculiar property, and is carried out by professional lawyers who have the relevant knowledge, skills and abilities;

- the primary classification of legal activity is its division into juridical practical, juridical scientific and juridical educational activities. Other features of juridical activity in this context include the usage of legal and non-legal means, its legal regulation, procedurality and so forth ${ }^{17}$.

In the scope of our research study, the scientific position of S.D. Gusarev is supported and taken as a basis concerning that juridical practice should be considered as a form of legal activity.

S.D. Gusarev notes that "legal activity is proposed to be understood as a type of social activity carried out by legal entities with the use of legal means and with the aim of obtaining a legal result, which contributes to the creation of law, its development and materialization in the process of functioning of public relations" 18 .

In his turn, S.D. Gusarev defines juridical activity as "a kind of legal activity carried out in the field of law by expert lawyers in order to obtain a legal result, meet the legitimate needs and interests of social entities in accordance with the requirements of law"19.

${ }^{16}$ Скакун О. Ф. Правова система України на правовій карті світу / Наукові доповіді інституту державного будівництва та місцевого самоврядування Академії правових наук України. Доповідь № 1. Х.: Еспада, 2004. С.62.

17 Гусарєв С.Д. Юридична діяльність: методологічні та теоретичні аспекти / С. Д. Гусарєв. К. : Знання, 2005. С.35.

${ }_{18}$ Гусарєв С. Д. Правова діяльність в структурі соціальної діяльності // Украӥнське право. 2005. № 1. С. 41

${ }^{19}$ Гусарєв С. Д. Юридична деонтологія (Основи юридичної діяльності): навч.посіб. / С. Д. Гусарєв, О. Д. Тихомиров. К. : Знання, 2005. С. 305. 
Analyzing the above-mentioned provisions, we can state that juridical activity is an important component of the functional block of the legal system. At the same time, there is no doubt that juridical activity is a special type of legal activity within the framework of social activity.

When determining the essential characteristics of juridical activity, its features should be taken into account. According to S.D. Gusarev and O.D. Tikhomirov's juridical activities are characterized by the following features: carried out in the field of law; performed by lawyers; aimed at organizing the activities of other entities; the purpose of juridical activity is to regulate and harmonize public relations; use of both legal and non-legal means; legal regulation of the results of juridical activity; availability of specific forms of implementation: practical, scientific and educational ${ }^{20}$.

The study of these features gives us the opportunity to discover the sociolegal nature of juridical activity and to come closer to understanding its first element, which, in our opinion, is a juridical algorithm.

"Legal activity is carried out in the field of law. The existence of law implies the presence of juridical activity, which ensures the functioning of the law, its effect. In the case of absence of legal norms and law in general, juridical work ceases to be so because it loses its object of influence and its basic toolkit. The sphere of law is all the structural levels and types of social relations where law actually exercises its influence. These are the various spheres of social life, the various situations in which people are guided by the provisions of legal acts to obtain a positive result. Even in such specific spheres of social life as the sphere of religious activity, the sphere of activity of public associations, law also has its influence, though in a somewhat indirect form" 21 .

"Legal activity is carried out by lawyers. This means that legal experts are employed in the field of juridical activity - professionals who have specialized legal knowledge, relevant work skills, and perform qualified legally sighnificant actions that determine the content of their work.

The complexity of situations that are solved by lawyers, the higher standarts of the legal procedure, the peculiarities of formal abstract thinking and terminology of legal communication imply that juridical work should be performed only by specially trained experts. If we analyze the legislation of Ukraine governing the activities of prosecuting authorities, courts, bar and some other bodies and institutions engaged in juridical activity, one of the

20 Гусарєв С. Д., Тихомиров О.Д. Юридична деонтологія (Основи юридичної діяльності): Навч. пос. К.: Знання, 2005. С. 37.

21 Гусарєв С. Д., Тихомиров О.Д. Юридична деонтологія (Основи юридичної діяльності): Навч. пос. К.: Знання, 2005. С. 38. 
requirements for candidates for the post is to have higher legal education. And for the lawyer's activities, for example, there is a requirement to pass the qualification examination, which is taken by a highly competent commission.

There are also relevant qualification commissions in the courts, which periodically check the level of professionalism of their employees. Additional requirements for applicants are proposed for the occupation of particularly responsible positions in legal institutions, which demand a special level of professionalism and considerable experience of legal practice"22.

"Juridical activity is aimed at organizing the activities of other legal entities. It is well known that law in relation to all its subjects exerts a formally equal influence, which is conditioned by the formal equality of the subjects of law in terms of the force of legal orders. However, despite this, a special group of entities stands out, which, in addition to fulfilling their status obligations, must determine the legal position of others, monitor the quality of their implementation of legal norms, assist them in the exercising of subjective rights and legal obligations, to create the right conditions to ensure a high level of implementation of legal rules. With their activities, lawyers assist in the preparation of laws and regulations that govern the life of society. On the basis of legal acts, individuals and legal entities request assistance of lawyers in solving specific situations. Publication of a law enforcement act of regulatory or protective character is one of the key examples of organizational and legal influence" ${ }^{, 23}$.

The purpose of juridical activity is regulation and harmonization of public relations. Law, as we know, establishes certain limits of the possibilities of the person, which cannot be surpassed, because as the boundary of anotherperson is violated, there is an interference with the sphere of rights of another subject.

The tasks that are solved in the course of juridical activity are generally to establish the limits of a possible behavior of the subject, to represent the client's interest, to fill the subjective possibilities with content, to protect the one's sphere from the unlawful interference of other subjects and to oblige the guilty ones to restoring a trespassed border" 24 .

"In the course of juridical activity, both legal and non-legal means are used. In the field of law it is impossible to do without such means, which are in one way or another connected with the law and act as the basic tool in the exercise of the lawyers' powers. Such means are the legal norms, legal

22 Гусарєв С. Д., Тихомиров О. Д. Юридична деонтологія (Основи юридичної діяльності): Навч. пос. К.: Знання, 2005. С. 38.

23 Гусарєв С.Д., Тихомиров О.Д. Юридична деонтологія (Основи юридичної діяльності): Навч. пос. К.: Знання, 2005. С. 39.

24 Гусарєв С.Д., Тихомиров О.Д. Юридична деонтологія (Основи юридичної діяльності): Навч. пос. К.: Знання, 2005. С. 40. 
relations, rights and obligations of legally significant documents and actions, individual legal instructions, orders, legal consciousness, acts of implementation of the law, etc. They are all derivative forms of law are legal phenomena. However, they have to function in different spheres of social life and in interaction with non-legal phenomena. The latter play the role of ancillary or subsidiary means used in the practical activity of lawyers and facilitate to increase their efficiency. Therefore, characterizing legal activity, one should speak of a combination of legal and non-legal means of exercising their powers. For example, along with drawing up a protocol on an administrative offense or issuing a decree recognizing a suspect as a party to the process, the rights and obligations, the nature of the guilt, the unlawful acts and the possible negative consequences are explained"25.

"Legal regulation of juridical activity. Law itself is a very powerful tool, which is explained by the possibility of using state-government coercion, the existence of an appropriate system of guarantees. Applying the legal norm to other persons is a form of exercise of power. Legal actions of lawyers can have serious consequences for other entities. Therefore, the activity of lawyers is well regulated by the legal norms, although the regulatory role of other social norms (norms of morality, corporate norms) can be mentioned.

The existence of a coherent system of organic laws governing the activities of the court, prosecutor's office, bar, police, notary, as well as the existence of a system of procedural laws and norms testify to the orderliness of the legal procedure. Each competence of an official, a legal institution is exercised in a certain form, according to a certain procedure and within a specified term. But a clear regulation of activity demands knowledge of its requirements not only by legal experts, but also by all other persons whose cases are the subject of consideration. Failure to comply with the procedure, violation of the terms of action can have adverse consequences, including in the form of legal liability"26.

"Juridical activity is carried out in the form of practical, scientific and educational activity. Each of these forms has its own peculiarities of purpose, content, means of implementation, etc. and takes place in a specific social environment covered by the concept of the sphere. In this triad, the practice of lawyers is a leading form, and educational and scientific practice appear to be additional or specific forms. Juridical educational and juridical scientific activities are equal elements in the system, and each performs its own

25 Гусарєв С. Д., Тихомиров О. Д. Юридична деонтологія (Основи юридичної діяльності): Навч. пос. К.: Знання, 2005. С. 40.

26 Гусарєв С. Д., Тихомиров О. Д. Юридична деонтологія (Основи юридичної діяльності): Навч. пос. К.: Знання, 2005. С. 41. 
function, which makes a harmonious combination and interaction of elements in the system" 27 .

In our opinion, in addition to these features of juridical activity, the following should be distinguished: juridical activity should be carried out in accordance with legal technologies; procedural and processual form of juridical activity; public and private levels of juridical activity; specialized logistical support of juridical activity.

Conformity of the performed juridical activity to legal technologies, in our opinion, is one of its most important features because it reflects the availability of knowledge regarding the rules, methods and means of organizing and conducting juridical activity.

Procedural-processual form characterizes the external form of manifestation of juridical activity. Juridical activity is always active, aimed at achieving a legal result, carried out in a certain legal order socially significant activity. The organization and the sequence of its implementation meets the requirements of the processual form and is carried out within the juridical process and procedures.

Public and private levels of juridical activity reflect not only the specific nature of its organization, but also indicate the presence of different, by their status, subjects of its implementation, from public servants to lawyers.

The feature of specialized logistical support of juridical activity is related, first of all, to the organization of practical juridical activity, but it does not exclude the need for financing of scientific and pedagogical juridical activity. Availability of the logistic, its systematic financing is the key to high-quality and effective juridical activity.

\section{Juridical algorithms and their place in the field of juridical activity.}

Having determined the nature of juridical activity, its nature and features, it becomes possible to characterize the place of juridical algorithms in the field of juridical activity.

Social regulators in the process of normative generalization of social relations are not only a form and the result of such generalization, but also a means of further ordering influence on the social system.

There is no doubt that social regulation can only happen if it is clearly defined who and in what order should perform certain actions or refrain from their implementation. Given the above-mentioned provisions and the nature of the juridical algorithm, it is possible to classify juridical algorithms according to the following criteria:

27 Гусарєв С. Д., Тихомиров О. Д. Юридична деонтологія (Основи юридичної діяльності): Навч. пос. К.: Знання, 2005. С. 41. 
According to the level of legal regulation: a) general juridical algorithms the provisions contained in the laws, for example, in Article 655 of the Civil Code of Ukraine states that under the contract of sale one party (seller) transfers or undertakes to transfer the property (goods) to the other party (the buyer), and the buyer accepts or undertakes to accept the property (goods) and to pay for it a certain sum of money; b) special juridical algorithms - the provisions contained in law-enforcing or enforcement acts, for example, in the Resolution of the Malinovsky District Court of Odessa on filing a case № 521/22090/14-c from 18.12.2014 the following juridical algorithm is indicated: Defendant is to file written objections to the claim, with reference to the evidence on which they are based ${ }^{28}$;

According to the form of legal activity of the subjects of law: a) juridical algorithms that are implemented through the action, for example, in paragraph 49.3 of Article 49 of the Tax Code of Ukraine it is stated that the tax return is submitted personally by the taxpayer or an authorized person $^{29}$; b) juridical algorithms that are put into practice through legally significant inaction, for example, Article 11 of the Criminal Code of Ukraine states that a crime is a socially dangerous action (act or omission) provided for in this Code and committed by the subject of the crime ${ }^{30}$. Thus, the juridical algorithm of legally significant inaction is the passive behavior of a legal entity to commit a socially dangerous act;

According to the type of legal norms: a) juridical algorithms that are expressed in substantive legal norms, for example, Article 88 of the Economic Code of Ukraine stipulates that members of a business enterprise have the right: to participate in the management of the affairs of the company in the manner specified in the constituent documents, except in cases provided in this Code and other laws ${ }^{31}$; b) juridical algorithms, which are expressed in procedural legal rules, for example, part 2 of Article 27 of the Civil Procedure Code of Ukraine stipulates that persons involved in a lawsuit are required to submit all their evidence before or during the preliminary court hearing in order to confirm their claims or objections, and if the preliminary court hearing is not conducted - before the trial of the merits ${ }^{32}$;

${ }^{28}$ Єдиний державний реєстр судових рішень. URL: http://www.reyestr.court.gov.ua/ Review/42016052

29 Податковий кодекс України від 21.12.2010 p. URL: http://zakon2.rada.gov.ua/ laws/show/1798-19

30 Кримінальний кодекс України від 05.04.2001 URL: http://zakon2.rada.gov.ua/laws/ show/2341-14

31 Господарський кодекс України від 16.01.2003 p. URL: http://zakon0.rada.gov.ua/ laws/show/436-15/paran720\#n720

32 Цивільний процесуальний кодекс України від 02.12 .2010 p. URL: http://zakon3.rada.gov.ua/laws/show/2755-17/paran1206\#n1206 
According to the nature of manifestation in social activity: a) processual juridical algorithms, for example, in part 1 of Article 314 of the Criminal Procedure Code of Ukraine, it is stated that after receiving an indictment, a request for the use of compulsory measures of medical or educational character or a application for an exemption from liability, not later than five days from the date of its receipt, the court appoints a preparatory hearing and summons the participants of the court proceeding ${ }^{33}$; b) juridical algorithms related to the process of procedures, for example, the Law of Ukraine "On Elections of People's Deputies of Ukraine" regulates the procedure for the implementation of separate procedures related to the election process (voting, participation in constituent meetings, etc.), so in part 5 of the Article 85 of this law stipulates that the ballot papers are filled by the voter personally in the booth for secret ballot ${ }^{34}$; c) juridical algorithms of independent legal procedures, for example in paragraph 10 of part 2 of Article 25 of the Law of Ukraine "On State Registration of Legal Entities, Individual Entrepreneurs and Public Organizations", it is stated that the Extract from the Unified State Register in paper form is provided with the signature and seals of the state registrar ${ }^{35}$;

According to the form of expression: a) written juridical algorithms - recorded in the texts of written legal acts; b) oral juridical algorithms - expressed in the officially recognized form of algorithms of verbal implementation of legal norms, for example, verbal order, verbal warning, etc.;

c) conjunctive juridical algorithms - expressed in an officially recognized form of acts of non-verbal or symbolic enforcement of legal rules, for example, subparagraph 1 of paragraph 33 of the Traffic Rules ${ }^{36}$ contains a description of a warning road sign, which, after its actual siting, will be a symbolic conjunctive act attributing certain algorithm of the behavior of subject of law.

According to the degree of historical development of the society: a) conscious algorithms that are based on mono-norms and reflect the order of achievement of the expected result through the implementation of interdependent actions by the individual, or through the refraining from their

\footnotetext{
33 Кримінальний процесуальний кодекс України від 13.04.2012 p. URL: http://zakon3.rada.gov.ua/laws/show/4651-17/paran2769\#n2769

34 Закон України "Про вибори народних депутатів України" від 17.01.2011 p. URL: http://zakon2.rada.gov.ua/laws/show/4061-17/paran1047\#n1047

35 Закон України "Про вибори народних депутатів України" від 17.01.2011 p. URL: http://zakon2.rada.gov.ua/laws/show/4061-17/paran1047\#n1047

36 Правила дорожнього руху від $10.10 .2001 \mathrm{p}$, затверджені Постановою КМУ від 10.10.2001 p., за № 1306 URL: http://zakon3.rada.gov.ua/laws/show/1306-2001-\%D0\%BF/ paran930\#n930
} 
implementation; b) juridical algorithms - the sequence of actions of the subject of law regulated by legal acts.

According to the feature of enforcement and the form of the prescription: a) rigid - algorithms that have a legally binding form; b) mild algorithms that are advisory.

Respectively, regardless of the nature (sequence) of the execution of legal orders, whether it is an action or an inaction (as in the case of the prohibition algorithm), the basis of such implementation is a legal algorithm (a sequence of actions regulated by a legal act).

\section{CONCLUSIONS}

The content and form of juridical activity is expressed in legal acts. The activity of lawyers and many other entities, including those with a competent legal awareness, is to create, effectively use or enforce legal acts.

Legal acts are an external expression and their legal composition and legal technologies are the starting points of the content of the formalization of law. The substantive and formal nature of the legal composition reflects the desired form of legal act, and legal technologies provide the rules, methods and techniques for their creation. The future effectiveness of written legal acts and, accordingly, their impact on the processes of legal regulation of public relations depends on the quality of these provisions.

Creation of legal documents is an integral part of juridical activity, and not only the form, but also certain procedures that transfer the actual relations into the expressed in a written act rule, order, fixation of status, etc. Formalization is a binding element of the law-making process.

It should be noted that in this case, we do not reduce the understanding of law only to the legalistic approach. The idea, the spirit, the principles of law, the, all these axiology notions, along with sociological aspects (conflict and its solution, the so-called "law in life") are also taken into account.

Each of them allows us to get closer to understanding the essence of law, as the most authoritative social regulator in modern society, and to identify issues that arise in the legal field. However, in the modern conditions, the "bare" idea of law (the right of a particular subject / entities) loses effectiveness of its implementation without formal certainty and connection with the state.

\section{SUMMARY}

In summary, it should be noted that juridical activities play an important role in the processes of social relations regulation. This is related not solely to the fact that the results of such activity are the creation of legal acts, but also, it is of great importance for our study, because due to effective juridical 
activity, the rights and freedoms of the subjects of law are embodied and their protection is ensured. The latter indicates that the juridical activity is carried out in accordance with a certain order, which, in our opinion, is clearly stated in the juridical algorithms.

\section{REFERENCES}

1. Господарський кодекс України від 16.01.2003 p. URL: http://zakon0.rada.gov.ua/laws/show/436-15/paran720\#n720

2. Гусарєв С. Д. Юридична деонтологія (Основи юридичної діяльності): навч. посіб. / С. Д. Гусарєв, О. Д. Тихомиров. К. : Знання, $2005.655 \mathrm{c}$.

3. Гусарєв С. Д. Юридична діяльність: методологічні та теоретичні аспекти / С. Д. Гусарєв. К. : Знання, 2005. 375 с.

4. Гусарєв С.Д. Правова діяльність в структурі соціальної діяльності // Украӥнське право. 2005. № 1. С. 41-50.

5. Єдиний державний реєстр судових рішень. URL: http://www.reyestr.court.gov.ua/Review/42016052

6. Жалинский А. Э. Профессиональная деятельность юриста. Введение в специальность. Учебное пособие / А. Э. Жалинский. М. : Издательство БЕК, 1997. 330 с.

7. Зайцев И. М. Понятие и содержание юридического процесса // Теория государства и права. Курс лекций. Под ред Матузова Н. И., Малько А.В. 2-е изд., перераб. и доп. М.: Юристъ, 2001. 442 с.

8. Закон України "Про вибори народних депутатів України" від 17.01.2011p. URL: http://zakon2.rada.gov.ua/laws/show/4061-17/paran 1047\#n1047

9. Карташов В. Н. Юридическая деятельность: понятие, структура, ценность. Саратов: Изд-во Саратовского ун-та, 1989. 218 с.

10. Кримінальний кодекс України від 05.04.2001 URL: http://zakon2.rada.gov.ua/laws/show/2341-14

11. Кримінальний процесуальний кодекс України від 13.04.2012 p. URL: http://zakon3.rada.gov.ua/laws/show/4651-17/paran2769\#n2769

12. Леушин В. И. Соотношение правовой практики и юридической деятельности / В. И. Леушин // Юридическая деятельность: сущность, структура, виды: Сб. науч. тр. Ярославль : Яр. ГУ, 1989. С. 47-53.

13. Леушин В. И. Юридическая практика в социалистическом обществе: (Гносеологический и специально-юридический аспект): Автореф. дис. ... д-ра юрид. наук : 12.00 .01 / Свердловск. юрид. ин-т им. Р. А. Руденко. Свердловск, 1990.35.

14. Мінченко О. В. Особливості здійснення юридичної діяльності в умовах германської правової сім'ї : автореф. дис... канд. юрид. наук: 
12.00.01 / Мінченко Ольга Василівна ; Київський національний ун-т внутрішніх справ. К., 2009. 20 с.

15. Оніщенко Н. М. Правова система: проблеми теорії: Монографія / Н. М. Оніщенко. К. : Ін-т держави і права ім. В. М. Корецького НАН України, 2002. $352 \mathrm{c.}$

16. Податковий кодекс України від 21.12.2010 p. URL: http://zakon2.rada.gov.ua/laws/show/1798-19

17. Правила дорожнього руху від 10.10.2001 p., затверджені Постановою КМУ від 10.10 .2001 p., за № 1306 URL: http://zakon3.rada.gov.ua/laws/show/1306-2001-\%D0\%BF/paran930\#n930

18. Правові системи сучасності. Глобалізація. Демократизм. Розвиток / В. С. Журавський, О. В. Зайчук, О. Л. Копиленко, Н. М. Оніщенко; за заг. ред. В. С. Журавського. К. : Юрінком Інтер, 2003. 296 с.

19. Скакун О. Ф. Правова система України на правовій карті світу / Наукові доповіді інституту державного будівництва та місцевого самоврядування Академії правових наук України. Доповідь № 1. Х.: Еспада, 2004. $96 \mathrm{c.}$

20. Тихомиров Д. О. Юридична діяльність в англо-амеріканській правовій сім’і (теоретико-правові аспекти) : автореф. дис... канд. юрид. наук: 12.00.01 / Тихомиров Денис Олександрович ; Київський національний ун-т внутрішніх справ. К., 2009. 16 с.

21. Цивільний процесуальний кодекс України від 02.12.2010 p. URL: http://zakon3.rada.gov.ua/laws/show/2755-17/paran1206\#n1206

22. Элементарные начала общей теории права. Учебное пособие / Гойман-Калинский И. В., Иванец Г. И., Червонюк В. И.; Под общ. ред.: Червонюк В. И. М.: Колос С, 2003. 544 с.

Information about the author: Manko D. G., Candidate of Juridical Sciences, Associate Professor at the Department of State and Law Disciplines, International Humanitarian University 33, Fontanska Road str., Odessa, 65009, Ukraine 


\section{METHODS OF PUBLIC ADMINISTRATION}

\section{Nenko S. S.}

\section{INTRODUCTION}

The problem of the methods of any activity is directly related to the more General problem - the ratio of the goal and the means to achieve it. Under the methods of activity usually understand the ways or means to achieve the goal, the solution of certain tasks.

Management is realized, as a rule, in purposeful influence on the corresponding object of management. It is in the process of such an impact that the management functions are practically realized, the tasks set for the subjects of management are achieved. Management influence is carried out with the help of certain techniques and means. Management methods are such techniques and means. They represent the relationship between the subjects and objects of management.

\section{The concept and system of administrative and legal methods of public (state) management}

Methods of public administration are various ways, means, receptions of direct influence of subjects of management and their officials on objects of management for the purpose of performance of the tasks and functions assigned to subjects.

Scientists often consider management methods as a set of techniques, operations and procedures for preparing and making, organizing and controlling the execution of management decisions made by participants in the management process. In other words, the method of management is a way of practical implementation of the goals, objectives and functions of management. Under the methods of management activities also understand the methods and techniques of analysis and evaluation of management situations, the use of legal and organizational forms of influence on the consciousness and behavior of people in controlled social processes, relationships and relationships. More often methods of management are defined as various ways, receptions and means of purposeful influence of subjects of management on consciousness, will and behavior of objects of management for the purpose of achievement of the purposes and performance of functions of management.

The main thing that characterizes the methods of public administration is that they are closely related to the purpose of management, which determines 
the specifics of the use of methods, their choice. Through management techniques is the connection of the subject of management and its object, then there is interaction in the management of one person with another person, team, group of people or team with another team. Management methods are the most active and effective mobile element in the management system. They can be used comprehensively, alternatively, complement each other, or alternate in application ${ }^{1}$.

Regardless of the content and direction of management methods are inherent:

- objective organizational form, which is understood as a type of influence, that is, an individual order (order, order, etc.) or norm (rule) of behavior;

- the nature of the impact (direct impact, indirect impact through the creation of stimulating or limiting conditions);

- method of influence (individual, collective, collegial);

- time characteristic (short-term and long-term);

- tactical and strategic nature.

Management methods are administrative and legal methods. It is in them that all the qualities of state-management activity are manifested, within the framework of which the Executive power is implemented. By means of administrative and legal methods the subject of Executive power carries out administrative influence on object by use of administrative and legal forms of management. In administrative law it is generally recognized that the method and form of management are interrelated parties to the management process. It is in an appropriate form control method actually performs the role of a method (means) of the control action. The form of management gives life to methods, and through them-and functions of management.

The state uses various methods to perform its tasks and functions. Traditionally, management methods are generally divided into scientific and unscientific, democratic and dictatorial, state and public, administrative and economic, General and special ${ }^{2}$.

At the heart of all methods of public administration are two universal means of state and public activity - persuasion and coercion. They permeate all other forms and methods of government.

Persuasion is a system of educational and incentive measures aimed at forming the habit of objects of management to voluntarily comply with the requirements of legal norms.

1 Kolpakov, V. Administrative responsibility (administrative-tort law): studies.no. / V. Kolpakov. Kyiv: Yurinkom Inter, 2008. 256 p.

${ }^{2}$ Kolomoets, T., Gulevskaya G., Administrative law of Ukraine: textbook / for General ed T. Kolomoets, G. Gulevskaya. Kiev: Istina, 2017. 216 p. 
Such activities include explanations, education, encouragement, criticism and the like. In most cases, administrative and legal norms are implemented voluntarily. Therefore, the method of persuasion is the main one in management activities. Non-state (public) coercion is closely related to persuasion. Measures of state coercion are applied when other means of influence on the relevant subjects have been exhausted.

Depending on the nature (content) of the impact, there are administrative and economic methods (direct and indirect).

Administrative methods are expressed in the adoption of decisions binding on the object of management, non-compliance with which entails administrative or disciplinary responsibility, that is, these objects are directly attributed to certain behavior. The controlling influence in this case is manifested in the unilateral definition of tasks, rights and obligations, a particular behavior of the object of management.

Economic methods are expressed in the creation of such conditions for the objects of management, in which they themselves choose the appropriate behavior under the influence of economic (material) incentives. Here the element of prescription characteristic of administrative methods is absent. The controlling effect is achieved by determining the economic benefits or damage. This means that the object of management is prompted to proper behavior; the other entails for him not legal responsibility, but the deterioration of the material (economic) condition. The means of such influence include the regulation of prices, profitability, taxes, credit policy ${ }^{3}$.

According to the degree of impact, public administration methods are divided into regulation, General management and direct management.

Regulation refers to the definition of a General policy in relation to the relevant branch of management and its implementation in regulations, that is, legal regulation. Regulation is used primarily in relations between state bodies and non-state enterprises, institutions, organizations, associations of citizens and citizens. In addition, regulation is often a prerequisite for overall leadership and direct management. This method is most often used by Central Executive authorities.

General guidance is the practical implementation of public policy through planning and forecasting, coordination of other actors, monitoring, assistance and the like. General management is exercised by all ministries and departments and other Executive bodies.

Direct management consists in direct and systematic influence on objects of management according to the set purpose and tasks. This is a routine, day-

\footnotetext{
${ }^{3}$ Bakhrakh, D. Administrative law of Russia: Textbook for universities / D. Bakhrakh. Moscow: Norma, 2012. 444 p.
} 
to-day management of an operational nature. It extends to the objects which are in direct subordination of governing bodies.

\section{Administrative coercion in the system of public administration methods}

Administrative coercion is a type of state coercion. State coercion in a democratic country is characterized by the fact that this method of exercising state power is auxiliary, applied on the basis of persuasion and only after persuasion. This means, first, that coercion is always based on the use of various measures of education, explanation and stimulation. Secondly, it is used only when the appropriate means of persuasion are ineffective. Third, persuasion and coercion are used, as a rule, comprehensively ${ }^{4}$.

State coercion and its component - administrative coercion should be considered as one of the integral components of the exercise of state power, as its method. On the other hand, this coercion is not an end in itself, it is a consequence of certain behavior of various social actors, behavior that deviates from the requirements of legal norms, is a threat to the relations that are regulated and protected by these norms, and is used to eliminate ("remove") such behavior. There are also cases when the threat to public relations arises objectively, for example due to the action of the forces of nature, that is, in the absence of illegal behavior, but the need to eliminate it is no less urgent.

State coercion is the only one that can be applied on behalf of the whole society to any persons located on the territory of the state, and also includes measures that other social actors cannot use. Such measures are just compulsory, that is, they are implemented regardless of the will and desire of the relevant objects. At the same time in the modern state that is characterized as legal, any activity which is carried out on its behalf, and especially activity on application of coercion, has to be accurately and completely regulated by the right, to be based on strict observance of its instructions ${ }^{5}$.

Therefore, state coercion is the application of special measures of influence to certain persons in order to induce them to comply with the requirements of legal norms. State coercion comes in two forms-as judicial and administrative (extrajudicial) coercion. In addition, state coercion is regulated by the norms of various branches of law, so it is simultaneously a legal coercion (civil law, disciplinary, administrative, criminal law).

4 Kolpakov, V. Administrative responsibility (administrative-tort law): studies.no. / V. Kolpakov. Kyiv: Yurinkom Inter, 2008. 256 p.

5 Vasilyev, A. Administrative law of Ukraine (General part): Textbook / A. Vasilyev. Kharkiv: "Odyssey", 2012. 288 p. 
Each type of coercion has specific features that determine its essence and features, relative independence in the system of state coercion. This is quite true of administrative coercion.

Administrative coercion is characterized by the following features:

- the use of administrative coercion is always combined with the extensive use of multifaceted educational tools, with the active formation of legal awareness, intolerant attitude to anti-social acts;

- administrative coercion is used in public administration to protect public relations arising in this sphere of public power;

- measures of administrative coercion are applied, as a rule, by Executive authorities and local self-government and their officials without recourse to the court. Only in some cases, as an exception, their application is assigned to the courts (judges) and representatives of individual associations of citizens endowed with some state powers (for example, members of public formations for the protection of public order and the state border, various public inspectors, etc);

- not all bodies of Executive power or local self-government and not all their officials are competent to apply administrative coercion measures, but only those of them to whom such right is granted by legislative acts (state inspections, paramilitary law enforcement formations-militia, security service, border, internal troops, etc.);

- administrative and coercive measures can be applied not only in connection with the Commission of offenses, but also in their absence, when it is necessary to prevent them or to ensure public order and public safety during various emergency situations (natural disasters, epidemics, epizootics, accidents, catastrophes, etc);

- unlike other types of state coercion, which in their essence, as a rule, are equivalent to the corresponding type of legal responsibility (for example, criminal legal coercion almost completely coincides with criminal responsibility), administrative coercion in content is much broader than administrative responsibility. After all, administrative responsibility is a component of administrative coercion;

- measures of administrative coercion are applied to both individuals and legal entities (the latter can be applied, for example, such measures as restriction or prohibition of certain works, suspension of activities of various facilities, etc.);

- administrative coercion is applied to organizations, officials and citizens who are not directly subordinated to the bodies and officials applying influence; that is, administrative coercion is not related to official subordination, cannot be carried out within a particular management system, and always has an external manifestation; 
- regulation of administrative coercion, grounds, conditions and procedure for the application of measures of influence is carried out by the norms of administrative law, and not only by laws, but also by a number of by-laws;

- activity on application of measures of administrative coercion is carried out according to administrative and procedural norms which for this time are fixed mainly at the level of by-laws, and norms of substantive law are generally not separated (except for the norms regulating the order of application of administrative penalties);

- measures of administrative coercion are very various, they can have character of moral, property, personal influence, application of physical force and firearms is allowed;

- measures of influence are applied in the compulsory order, that is irrespective of will and desire of the subject to which it is applied" often with possibility of use for its implementation of other compulsory measures;

- administrative coercion is applied with a threefold purpose: 1) to prevent various anti-social manifestations, to prevent the emergence of a certain illegal situation; 2) to stop the initiated or already committed illegal act and to ensure the proceedings in cases of administrative offenses; 3 ) to punish persons who have committed offenses.

Therefore, administrative coercion can be defined as the application by the relevant subjects to persons who are not under their control, regardless of the will and desire of the latter, provided by administrative and legal norms of measures of influence of moral, property, personal (physical) and other nature in order to protect the relevant public relations by preventing and suppressing offenses, as well as punishment for their Commission.

In the administrative and legal literature, the issues of classification of administrative coercion measures have not yet been unambiguously resolved, despite their great practical and theoretical importance. At the same time, the classification of these measures, proposed at the time by N. Yropkin ${ }^{6}$, which is the basis of their classification put the purpose of application, received the greatest recognition.

As indicated, administrative coercion is used for a threefold purpose. In accordance with this, administrative enforcement measures are divided into three types (groups):

1) administrative and preventive measures;

2) measures of administrative restraint;

3) measures of administrative responsibility.

${ }^{6}$ Administrative law of Ukraine. Academic course: Textbook: in two volumes: Volume 1. Common part. / Editorial Board: V. Averyanov (head). Kiev: publishing house "legal opinion", 2014. 584 p. 
This division most clearly reflects the law enforcement purpose of administrative coercion.

Some scientists expressed opinion about lack of administratively-measures precautionary and existence of so-called restorative measures. Precautions supporters of this point of view refer to the rules of law, because they allegedly addressed not to the individual, but to all (or many) citizens. This position cannot be considered indisputable, since administrative preventive measures can be applied to both groups of citizens and individuals (for example, verification of documents, administrative supervision of persons released from prison, etc.).

In the scientific literature made reasoned objections against the attribution of these activities. More convincing is the position of scientists who believe that administrative enforcement of law as the main goal is not peculiar. The analysis of these measures shows that they include diversified coercive measures-civil law, financial law, criminal law.

Some scientists-administrativisty Express thought about existence of another independent groups measures administrative coercion administrative-procedural ensure (coercion). Such a group of coercive measures actually exists, but it is one of the types of preventive measures, and not coercion in General, that is, it is not a type of coercion, but its subspecies.

There are other approaches to the classification of administrative coercion measures with minor differences from those mentioned. However, the majority of domestic administrationists support the division of administrative coercion into measures of prevention, suppression and administrative responsibility. At the same time, the above classification, like any other, is somewhat conditional, so from time to time it is criticized, its main purpose is to fully clarify the essence of administrative coercion measures, the grounds and procedure for their application.

\section{Administrative and preventive measures}

The name of administrative measures is due to their preventive orientation. These measures are specific, factual grounds for the application are not, they are used to prevent offenses, as well as to maintain law and order under emergency conditions because a threat to public and personal interests, damage can occur not only as a result of the offense, but as a result of natural disasters, actions of the mentally ill or minors, and the like. The state is then forced to resort to the restriction of rights, the application of coercive measures to persons innocent of violating the law ${ }^{7}$.

${ }^{7}$ Bityak Y., Garashchuk V., Dyachenko O. Administrative law of Ukraine / textbook Y. Bityak, V. Garashchuk, O. Dyachenko et al.; edited by Y. Bityak. Kyiv: Yurinkom Inter, 2015. 544 p. 
These are the actions of health authorities, which forcibly treat infectious patients, veterinary medicine, which carry out quarantine measures. In most such cases, there is no offense, but the freedom of action of the person is limited, the appropriate administrative measures are applied regardless of the consent or desire of the latter, that is, have a coercive nature.

Administrative preventive measures do not perform the function of punishing the person to whom they are applied, which is typical for administrative penalties, so they do not require the establishment of the offender's guilt as a mandatory condition of application ${ }^{8}$.

The main purpose of the application of administrative measures is their focus on:

a) prevention, diversion of offences;

b) ensuring public order and public safety in various emergency situations;

c) prevention of occurrence of harmful consequences in the specified situations.

Therefore, administrative and preventive measures constitute a set of measures of influence of moral, physical, organizational and other nature, which allow to identify and prevent offenses, to ensure public order and public safety in various emergency circumstances.

These measures are applied by many bodies and their officials: the police, the internal troops, the border service, the security service, the control and Supervisory authorities (state inspections) and the like.

The application of certain administrative measures is governed by a significant number of laws and other regulations. These are the Customs code of Ukraine, the laws of Ukraine "on the National police", "on the state border service of Ukraine", "on the security Service of Ukraine", "on veterinary medicine", regulations on various state inspections, etc.

Among the administrative measures of restraint, the following occupy a dominant place.

Document check.

So, police officers have the right to check at citizens the documents proving their identity, at suspicion in Commission of an offense, and also other documents necessary for clarification of a question concerning observance of rules which supervision and control of which performance is assigned to militia (item 2 of Art. 11 of The law "about militia"). For this purpose, officials of other state bodies, which exercise control and supervision over compliance with the relevant mandatory rules, also have the right to check documents.

${ }^{8}$ Bakhrakh, D. Administrative law of Russia: Textbook for universities / D. Bakhrakh. Moscow: Norma, 2012. 444 p. 
Inspection taking into account the purpose and method of law enforcement impact on public relations is most often used as a measure of administrative prevention.

For example, customs authorities carry out customs inspection and reexamination, internal Affairs and civil aviation bodies-mandatory inspection of hand Luggage, baggage and personal inspection of passengers of civil aircraft, border guard bodies-inspection of sea and river vessels and documents; departmental security-inspection of persons who work at facilities with special regime, and so on. In all these cases, the main purpose of this measure is the prevention and detection of offenses, ensuring public safety, that is, it has a clear preventive character.

Visiting enterprises, institutions and organizations, entering land plots, residential and other premises of citizens is possible only in clearly defined cases.

So, the police have the right freely at any time of the day you go to: a) the territory and premises of enterprises, institutions and organizations, including customs, and to examine them with the aim of cessation of crimes, prosecution of persons suspected of committing crimes, in natural disaster and other emergencies; b) for land in residential and other premises of citizens, if the pursuit of the criminal or stopping a crime, endangering the lives of residents, as well as in case of natural disaster and other emergencies; c) in premises of the citizens who are under administrative supervision for the purpose of check of performance of the restrictions established by court. Officials of many other bodies can also visit enterprises, institutions, organizations to perform control and preventive functions.

Introduction of representation on elimination of the reasons and conditions promoting Commission of offenses is provided in a number of legislative acts. Administrative law is a rule established in article 282 of the code of Ukraine on administrative offences (CAO), under which the subject of administrative jurisdiction, hearing the case, setting the causes and conditions that contributed to the Commission of administrative violations, contributing to the appropriate state authority, public organization or official proposals of measures to eliminate these causes and conditions. The body (official) that made the proposal must be informed about the measures taken within one month from the date of receipt of the proposal.

Temporary restriction of access of citizens on separate sites of the district (blocking of districts of the district, separate constructions and objects) can be applied by employees of police and the military personnel of Internal troops.

Thus, police officers have the right to temporarily restrict or prohibit the access of citizens to certain areas of terrain or objects in order to ensure public order, public safety, protection of life and health of people in the event of 
escape from custody and detention of a criminal, accidents on the roads, in other emergency circumstances that threaten the life and health of people (earthquakes, floods, outbreaks of epidemics and epizootics), as well as during mass events-demonstrations, rallies, competitions, etc.

In order to ensure public order and public safety, police officers also have the right to restrict traffic and pedestrians on certain sections of streets and roads. The reasons for these restrictions may be the repair of roads, laying communications, emergency, fires, natural disasters, demonstrations, rallies, mass campaigns, competitions and the like.

Gratuitous use of vehicles and communication facilities belonging to enterprises, institutions and organizations (except for vehicles of diplomatic, consular and other missions of foreign States, international organizations and vehicles of special purpose), is carried out with the aim of preventing harmful consequences of natural disasters, other emergencies, for travel to the immediate scene, for delivery to medical institutions of persons requiring emergency medical care, to prosecute the offenders and delivering them to the police.

Administrative supervision of persons released from prison supervision is a system of temporary compulsory preventive measures to monitor and control the behavior of individuals released from prison by the National police. The decision on its application shall be taken solely by the judge of the district (city) court on the proposal of the head of the correctional labor institution or the police body for a period of one to two years and may not exceed the terms provided by law for the repayment or removal of a criminal record.

The restrictions that the supervised person must comply with include: the prohibition of leaving the house, apartment at a set time, cannot exceed 8 hours a day; the prohibition of staying in certain places of the district (city); the prohibition of departure or restriction of the time of departure for personal Affairs outside the district (city); the obligation to appear to the police for registration. A person violating these restrictions shall be subject to administrative liability in accordance with article 187 of the administrative Code.

In conclusion, it should be emphasized that the range of administrative and preventive measures under consideration is not exhaustive. These are the most common measures, the protective nature of which is almost beyond doubt. The legislation provides for the possibility of applying many other measures, which can also be considered administrative and protective 9 .

\footnotetext{
${ }^{9}$ Kolomoets, T., Gulevskaya G., Administrative law of Ukraine: textbook / for General ed T. Kolomoets, G. Gulevskaya. Kiev: Istina, 2017. 216 p.
} 


\section{Measures of administrative restraint}

Measures of administrative restraint - the most numerous and most diverse of all administrative-coercive measures-are characterized primarily by the fact that their application is caused by a real illegal (including objectively illegal) situation and begins at the moment when it has reached a certain development, that is, when the use of preventive measures becomes ineffective or completely useless.

Measures of administrative restraint do not turn away, but directly stop the existing offenses or objectively illegal acts that create conditions for establishing the identity of the offender, clarifying the circumstances of the case and the real possibility for further application of administrative or other measures to the offender.

Unlike administrative penalties, administrative preventive measures do not contain an element of punishment of the person to whom they are applied. Performing along with the educational punitive function, administrative punishment for its action in time is turned into the past, is retrospective. Measures of administrative restraint, as a rule, are directed to the present and therefore are able to independently and quickly resolve the conflict situation, in particular, forcibly suppress offenses ${ }^{10}$.

They can also provide conditions for the subsequent application of measures of responsibility to the perpetrators. Often, preventive measures are used to combat objectively illegal acts of mentally ill and young people, that is, persons who are not subject to legal responsibility. Measures of administrative termination, as well as administrative-preventive measures, do not require the presence of the offender's guilt as a mandatory condition of application.

All this allows to define measures of administrative restraint as the compulsory termination of the acts based on the law having signs of an administrative offense, and in separate cases - and criminal-legal character directed on prevention of harmful consequences of illegal behavior, ensuring production on cases of administrative offenses and attraction guilty to administrative, and in exceptional cases - criminal responsibility. Measures of administrative restraint are applied for the purpose of:

a) suppression of violations of legal norms (administrative offenses, crimes and objectively illegal acts);

b) preventing the Commission of further offences;

c) creation of conditions for further bringing the perpetrators to justice;

d) elimination of harmful consequences of the offense;

${ }^{10}$ Vasilyev, A. Administrative law of Ukraine (General part): Textbook / A. Vasilyev. Kharkiv: "Odyssey", 2012. 288 p. 
e) restoration of the previous, lawful state.

Measures of administrative restraint are very heterogeneous, differ from each other in many ways. However, their main classification should be carried out in accordance with the nature of the scope of application. According to this criterion, measures of administrative restraint are divided into two groups (types) - General and special measures.

Measures of administrative restraint of General purpose, which are used in everyday practice by many law enforcement agencies, are mainly divided, based on the purpose of their application, into independent (operational) and auxiliary (security).

1. Independent (or operational) measures of administrative restraint are characterized by the fact that they quickly resolve the conflict situation, that is, the conflict is most often exhausted completely. To some extent, it can be argued that these measures (at least most of them) are on the verge of proper preventive measures and administrative penalties. For example, an official warning about the inadmissibility of illegal behavior is very similar in nature to such an administrative penalty as a warning.

The requirement to cease the wrongful conduct. Such a requirement may (and must) put law enforcement officials, various state inspectors in the event of detection of such behavior. The basis of application of the specified action the termination can make any offense, including a crime. The requirement can be expressed orally, and also is issued in the form of the written instruction (order). It is legally binding, disobedience to this requirement is the basis for the application of other coercive measures.

Bringing persons who evade the appearance in various state bodies and institutions (courts, prosecutors, health, internal Affairs, military commissariats, etc.), is a reaction to the failure of citizens and officials of the legal obligation to be on their call, a means of ensuring the performance of this duty. The drive is carried out by the police and consists in the forcible delivery of the person to the appropriate body or institutions. That is, it is the removal of her from the place of stay and escort to the destination, combined with the use of mental or physical motivation.

Administrative detention not related to the implementation of proceedings on administrative offences. In particular, we are talking about the arrest with the content in specially designated premises: minors under 16 years old who are left without care, as well as minors who have committed socially dangerous acts and have not attained the age of criminal responsibility; individuals who showed disobedience to the lawful demands of a police officer; at the same time, on July 1, 2010, the constitutional Court of Ukraine promulgated a decision according to which law enforcement officials have no right to detain persons suspected of vagrancy, since such actions violate the 
basic principles of the Constitution and laws of Ukraine regarding the rights and freedoms of citizens. Therefore, this provision of the Law is currently not valid, then persons who evade the implementation of the court order on the direction of compulsory treatment for chronic alcoholism or drug addiction; the military personnel who have committed the acts falling under signs of a crime or an administrative offense; the persons having signs of the expressed mental disorder and create in this connection real danger for themselves and people around.

Registration and official warning about the inadmissibility of illegal behavior is applied by the police to persons who systematically violate public order, if these violations are minor in nature and do not entail legal responsibility (family conflicts, malicious drunkenness, domestic violations, etc.). Caution is to warn the person about the inadmissibility of illegal actions and the consequences of their repetition or continuation. A Protocol shall be drawn up on the issuance of an official reservation to a person. An official warning cannot be applied in cases where there are sufficient grounds for bringing a person to administrative or even criminal responsibility.

The termination of vehicles is carried out by employees of bodies of National police according to Art. 35 of the Law of Ukraine "About National police" where the exhaustive list of the bases of application of this action is provided. Failure by the driver of the requirement of the employee of police about a vehicle stop makes structure of the administrative offense provided by part one of Art. 1222 of the administrative Code.

Prohibition or suspension of certain works or operation of various objects (including operation of various machines and mechanisms-self-propelled agricultural machines, river or small vessels, etc.).

This event falls within the competence of a number of law enforcement and Supervisory authorities (state inspections). In particular, the police have the right to prohibit the operation of vehicles whose technical condition threatens road safety, to limit or prohibit repair, construction and other works on streets and roads, if the safety requirements are not met, to cancel permits for the use of objects of the licensing system in case of violations of its rules ${ }^{11}$.

According to item 4 of Art. 10 of the Law of Ukraine "About the state control and audit service in Ukraine" bodies of this service have the right to seal cash desks and cash rooms, warehouses, archives in case of detection of violations of the legislation on financial questions. Executive authorities of General competence and local self-government bodies may restrict,

${ }^{11}$ Bityak Y., Garashchuk V., Dyachenko O. Administrative law of Ukraine / textbook Y. Bityak, V. Garashchuk, O. Dyachenko et al.; edited by Y. Bityak. Kyiv: Yurinkom Inter, 2015. $544 \mathrm{p}$. 
temporarily prohibit (stop) or stop the use of atmospheric air as raw materials for primary production purposes in case of violation of the terms of permits and requirements of standards (article 32 Of the law of Ukraine "on protection of atmospheric air").

Many other state bodies - sanitary and epidemiological service, veterinary medicine, environmental protection and the like-also have similar powers.

2. Measures to ensure the proceedings in cases of administrative offenses constitute a special group of administrative preventive measures, the specificity of which is that they are not independent, but auxiliary measures of influence: their application ensures the creation of conditions for bringing the offender to administrative responsibility (in some cases to criminal).

Delivery of the offender to the police, the policing point, premises of the Executive Committee of the village, the village Council, office of the home guard shall be applied in accordance with article 259 of the administrative code to stop the offenses, the identity of the intruder and the Protocol on an administrative offense if it is impossible to make it on the spot if the Protocol is required. Delivery is compulsory escort of the offender to the appropriate premises. Police officers, officials of transport bodies, bodies that control the protection and use of natural resources, members of public formations for the protection of public order and public inspectors of nature protection have the right to exercise it.

Administrative detention as a measure of ensuring the proceedings in cases of administrative offenses is a forced short-term restriction of the freedom of action and movement of the offender. Administrative detention can be applied not for any administrative offenses, but only for some of them listed in Art. 262 of the administrative Code (petty hooliganism, malicious disobedience, violation of the rules of the border regime, etc.), and only by the bodies specified in this article. Administrative detention, as a rule, cannot exceed three hours. This is a General rule, and detention for such a period is called General. Longer periods of administrative detention can be established only by legislative acts.

A Protocol must be drawn up on administrative detention. On the place of stay of the person detained for Commission of an administrative offense, his relatives, and at his request - also the head of the corresponding enterprise, establishment, the organization or the body authorized by it are immediately notified.

Review and review things. By the nature of the object of influence, these are different coercive measures, but in content they do not differ from each other. Personal inspection is performed by a person of the same sex with the offender in the presence of two witnesses of the same sex. The law does not require the participation of witnesses. In urgent cases things can be subjected 
to review and in the absence of owner or owner, but participation understood in such cases necessarily. Carrying out inspection is made out by the special Protocol or about it record in the Protocol on an administrative offense or in the Protocol on administrative detention becomes.

The seizure of things and documents may take place after the application of two preliminary measures-administrative detention or inspection. It consists in the compulsory termination of possession (and as a consequence, use and disposal) by a person who has committed an administrative offense, a certain object or document.

Things which are the tool or a direct subject of an offense can be material evidences on business are subject to withdrawal. About their withdrawal the separate Protocol is made or the record in the Protocol on an administrative offense, administrative detention or inspection of things becomes. To the person who has committed an administrative offense in the performance of official duties, the seizure of things (as well as personal inspection and inspection of things) is applied only in urgent cases. Articles 265-1 of the administrative Code provide for the features of the seizure of certain types of things and documents, their seizure from individuals and the procedural registration of the seizure of some things.

So, Art. 265-1 of the administrative Code defines features of temporary withdrawal of the driver's license, V. 265-2-features of temporary detention of vehicles.

Suspension of drivers from driving vehicles and inspection of them on a state of intoxication according to Art. 266 of the administrative Code are applied in cases when there are sufficient bases to believe that drivers are in such state. The normative basis for the application of this measure, in addition to article 266 of the administrative Code, is also the Resolution of the Cabinet of Ministers of Ukraine of December 17, 2008. No. 1103 "On approval of the Procedure of direction of drivers of motor vehicles to conduct inspection in order to detect the condition of alcoholic, narcotic or other intoxication or stay under influence of drugs that reduce attention and speed of reaction, and such an inspection". The decision to conduct the search is made by officials of the National police. Directly inspection on a state of intoxication can be carried out by means of the Drager device or in medical institutions.

The measure of restraint for special purposes should be defined as a complex of exclusive, extraordinary measures of administrative influence. The special nature of these measures determines the specifics of the grounds for their application. These are, as a rule, urgent cases when it is necessary to stop illegal actions dangerous to life and health of people. 
In addition, special measures are used when all other forms of preliminary impact on offenders have been used and have not yielded the desired results. Therefore, the use of force, special means and weapons should be preceded by a warning of the intention to use them, if the situation permits. In cases where there is a real danger to life or health, these measures may be applied without warning.

Special these actions are called also because they are directed directly to the person of the violator, are capable to cause it a certain physical harm and even to deprive of his life. In this regard, the law requires law enforcement officials to use force within the limits of necessity and only when it is impossible to avoid its use. In this case, the possibility of harm to the health of the offender should be minimal.

The use of force against the elderly, pregnant women, persons with disabilities and minors is permitted only in cases of group or armed attack or armed resistance to law enforcement officials. If the use of preventive measures of special purpose caused harm to citizens, the necessary assistance should be provided as soon as possible.

- Measures of physical influence are applied for suppression of offenses or overcoming of counteraction to lawful requirements of militia or other law enforcement agencies.

- Special means-a variety of technical means of influence on the offender, and in some cases-also on vehicles and other things in order to eliminate the illegal situation.

- Firearms may be used by police officers of law enforcement agencies according to art. . 46 of the Law of Ukraine "on National police".

On the same grounds can use firearms, and employees of other law enforcement agencies.

\section{CONCLUSIONS}

The concept of public administration methods, their classification. Persuasion and coercion in public administration. Methods of direct and indirect control. Administrative and economic methods. Regulation, General management and direct management.

\section{SUMMARY}

The considered measures of administrative termination do not completely exhaust their list, since neither at the legislative nor at the doctrinal level this list, as well as the list of administrative measures, is clearly defined. Such a task should be solved in the course of further codification of the administrative legislation of Ukraine. 


\section{REFERENCES}

1. Administrative law of Ukraine. Academic course: Textbook: in two volumes: Volume 1. Common part. / Editorial Board: V. Averyanov (head). Kiev: publishing house "legal opinion", 2014. 584 p.

2. Bakhrakh, D. Administrative law of Russia: Textbook for universities/D. Bakhrakh. Moscow: Norma, 2012. 444 p.

3. Bityak Y., Garashchuk V., Dyachenko O. Administrative law of Ukraine / textbook Y. Bityak, V. Garashchuk, O. Dyachenko et al.; edited by Y. Bityak. Kyiv: Yurinkom Inter, 2015. 544 p.

4. Vasilyev, A. Administrative law of Ukraine (General part): Textbook / A. Vasilyev. Kharkiv: "Odyssey", 2012. 288 p.

5. Kolomoets, T., Gulevskaya G., Administrative law of Ukraine: textbook / for General ed T. Kolomoets, G. Gulevskaya. Kiev: Istina, 2017. $216 \mathrm{p}$.

6. Kolpakov, V. Administrative responsibility (administrative-tort law): studies.no. / V. Kolpakov. Kyiv: Yurinkom Inter, 2008. 256 p.

\section{Information about the author:} Nenko S. S.,

Candidate of Law, Associate Professor, Professor at the Department of Administrative,

Criminal Law and Procedure, International University of Business and Law 37-A, 49 HGD str., Kherson, 73040, Ukraine 


\title{
OFFENSES RELATED OF GOODS / ITEMS ACROSS THE CUSTOMS BORDER: NATURE AND BUSSINES COMPONENT
}

\author{
Palamarchuk G. V., Neledva N. V.
}

\section{INTRODUCTION}

In today's context, shadow economic activity plays a significant role in creating a unique socio-economic and cultural space, adversely affecting the development of the national economy as a whole and its strategic industries, in particular, contributing to the development of other illegal activities. Among the shadow business areas, special attention should be paid to its types that go beyond national borders. These are offenses related to the movement of goods / items across the customs border.

Today, not only smuggling but also other offenses related to the movement of goods / items across the customs border are a threat to Ukraine, as noncriminalized forms of cross-border shadow business cause the greatest economic and political damage. But their criminological analysis is complicated by the inconsistency of the legal assessment of a number of such offenses, the presence of temporarily occupied territories with different legal status, etc.

Given the predominantly organized nature of offenses related to the movement of goods / items across borders, the distribution of roles within criminal groups, the ramifications and resilience of corrupt relationships of the perpetrators, the organizational and legal imperfection of the available preventive measures, thorough criminological intelligence on the current state of these offenses in Ukraine at the present stage and improving its prevention system.

Comprehensive analysis of offenses related to the movement of goods / items across the customs border as a separate criminological group of socially dangerous economic activities provides an opportunity for a clearer definition of the main directions of their prevention.

\section{Offenses relating to the movement of goods / items across the customs border: nature and legal nature}

In terms of the historical patterns of the notion of offenses related to the movement of goods / items across the customs border, historically, everything started from smuggling - the economic and legal nucleus of the whole set of offenses. In the context of intelligence on the essence of this action, it is advisable to refer to foreign sources. 
A classic study of the nature of smuggling and its impact on the well-being of society is the work of J. Bhagwati and B. Hansen (1973) ${ }^{1}$. They were the first to introduce the theory of smuggling, which was considered solely as an import-substituting economic activity, and showed that smuggling was able to improve public well-being because it could transfer resources from the public to the private sector. As for the potential economic costs of the smuggler, transportation costs were indicated. The latter position was supplemented by Sheikh M.A. (1974) - an indication of risk costs (relative to goods confiscated and taxed $)^{2}$.

Model M. Pitt (1981) explained the smuggling of goods using the export duty: the reason for smuggling was suggested to be the excess of the domestic price over the world except for the duty, that is, under these conditions, legal exports brought absolute losses. However, firms are forced to export legally solely to cover smuggling activities in order to reduce the cost of smuggling ${ }^{3}$.

In his study, On Northeastern Theory of Smuggling (1988), D. Norton views smuggling as a crime of opportunity made possible by different tariffs or price disparities in different markets ${ }^{4}$.

F. Chowdhury (1999) proposed a model of production-based smuggling, in which price disparities are critical as an incentive to engage in smuggling 5 . These disparities are caused by the presence of internal indirect taxes and import duties. Therefore, the reduction of internal taxes is considered in the context of the ability of an internal producer to offer goods at lower prices and to reduce price disparities that stimulate smuggling. However, the author suggested that there was a limit beyond which a reduction in domestic production taxes would not be able to add competitive advantages. Thus, confiscation measures are needed to increase the cost of smuggling and make it uncompetitive.

The Encyclopedia of Criminology and Deviant Behavior defines smuggling as the illegal import of goods from one jurisdiction to another. Illegal operations may include the importation or exportation of illicit goods (eg drugs) or the evasion of foreign trade taxes, including duties, on goods,

${ }^{1}$ Bhagwati J., Hansen B. A Theoretical Analysis of Smuggling. The Quarterly Journal of Economics. Vol.87. № 2. (May, 1973). P. 172-187.

${ }^{2}$ Sheikh M.A. Smuggling, production and welfare. Journal of International Economics. 1974. № 4. P. 355-364.

${ }^{3}$ Pitt M. Smuggling and price disparity. Journal of International Economics. 1981. № 11. P. 447-458.

${ }^{4}$ Norton D.A. On the Economic Theory of Smuggling. Economica, New Series. Vol. 55. № 217. (Feb., 1988). P. 107-118.

${ }^{5}$ Chowdhury F.L. Smuggling, Tax Structure and The Need for Anti-Smuggling Drive. Fiscal Frontier. Vol.VI. 2000. URL: http://www.answers.com/topic/faizul-latif-chowdhury. (дата звернення: 10.12.2019) 
exports or imports of which are subject to customs duties (eg diamonds, cigarettes). Price disparities and different levels of duty rates in different jurisdictions or at different times determine the likelihood of smuggling ${ }^{6}$.

Thus, economists emphasize that smuggling is motivated by risk-taking strategies driven by the desire to avoid taxes or to obtain money from the sale of illegally imported goods. Complementing the view that economic conditions affect smuggling, economists also argue that smuggling affects price disparities and other economic aspects.

It should be emphasized that in most Western criminological studies, smuggling is defined as a "crime of opportunity" and its commission is intended to make a profit. Based on this concept of smuggling, Paulus and Gimron's (1981) studies have shown that individuals crossing the border are clearly aware of the illegality of smuggling ${ }^{7}$. When crossing the border, the smuggler must directly decide on the non-declaration of goods and, accordingly, on the violation of the law. As D. Braithwaite pointed out, if economic agents do not act in accordance with the laws, then they certainly act in the light of the existence of laws ${ }^{8}$. Accordingly, persons who commit various offenses when crossing the border try to rationally weigh the pros and cons of violations of customs rules and choose the type of behavior that benefits them in the current situation.

Smuggling is distinguished from "gray imports", although tax evasion is manifested in the case of both "gray imports" and smuggling ("black imports"). The term "gray imports" refers to goods being transported to a country with a decrease in tariff payments due to false declaration, that is, "gray schemes" of import should mean a decrease in the customs value of goods, wrong definition of the country of origin of goods and their codes 9 . Smuggling is a situation where moving across the customs border of a particular product / item does not exclude taxes at all, the fact of crossing the border is not recorded in any customs documents.

This action is aimed at avoiding / neutralizing:

1. Control in the event that the moving goods / items do not meet the existing safety requirements or are prohibited from import / export.

${ }^{6}$ Black Market Contraband Index. URL: http://www.havocscope.com/products.htm. (дата звернення: 10.12.2019)

${ }^{7}$ Paulus I., Simpson C. Opportunity, Benefit, and Subjective Disposition: Determinants of Nonprofessional Smuggling. The Pacific Sociological Review. Vol. 24. № 3 (Jul., 1981). P. 299-327.

${ }^{8}$ Брейтуэйт Д. Преступление, стыд и воссоединение / Пер. с англ. Н.Д. Хариковой; под общ. ред. М.Г. Флямера. М. : МОО Центр “Судебно-правовая реформа”. 2002. С. 210.

${ }^{9}$ Визначення митної вартості та підтвердження країни походження: Офіційний портал Державної фіскальної служби України URL: http://poltava.sfs.gov.ua. (дата звернення: 10.12.2019) 
2. Costs related to payment of customs duties and taxes.

3. Costs related to distribution (sale), since in most cases illegally imported goods are in the shadow segment of the market or legalized contrary to established requirements.

4. Regulation of intellectual property rights (audio and video recordings, finished products for domestic or industrial use, etc.).

In the economic sense, offenses related to the movement of goods / items across the customs border have traditionally been associated with tax evasion, fees, customs duties, etc., giving some reason to consider such offenses to be tax offenses.

However, it should be emphasized that these offenses are heterogeneous. They may be related to the trafficking of both illicit goods / items and illicit ones (such as drug smuggling). Obviously, the second type of offense is unrelated to tax evasion, since it is impossible to tax transactions with prohibited items.

However, if the nature of the offenses related to the movement of goods / items across the customs border is purely economic, then their legal nature is much more complicated.

Smuggling in Ukraine is an exclusively criminal act. Along with it in MK Ukraine there is a kind of offense called "violation of customs rules". Violation of customs rules is unlawful, guilty (intentional or negligent) acts or omissions that encroach on the procedure of moving goods, vehicles for commercial purposes across the customs border of Ukraine, established by the MK of Ukraine and presenting them to the customs authorities for carrying out customs control and customs clearance, as well as transactions with goods under customs control or control which are assigned to the customs authorities by this Code or other laws of Ukraine, and for which this Code provides for administrative liability (Article 458 of the Customs Code of Ukraine) ${ }^{10}$. Administrative liability for offenses arises if these offenses do not entail criminal liability.

Thus, the difference in the degree of public danger between criminal and customs offenses is due to the characteristics of the objects of the respective actions. And in a simplified form, smuggling can be presented as a "criminal offense". In this case, smuggling in Ukraine mainly involves items seized or restricted in civilian circulation. A certain exception is the subject of the criminal offense under Article 201-1 of the Criminal Code of Ukraine ${ }^{11}$.

\footnotetext{
10 Митний Кодекс України: Закон України від 13.03.2012 № 4495-VI. URL: https://zakon.rada.gov.ua/laws/show/4495-17/ed20120603(дата звернення: 10.12.2019)

11 Кримінальний кодекс України: Закон України від 17.01.2002 № 4495-VI. URL: https://zakon.rada.gov.ua/laws/show/2341-14. (дата звернення: 10.12.2019)
} 
Therefore, as a whole, smuggling, as opposed to violation of customs rules, cannot be considered as a kind of tax evasion or other payments today.

However, the question arises: does the economic nature of the smuggling persist with the position of the legislator? It seems that, because modern smuggling, like other types of offenses related to the movement of goods / items across the customs border, as will be shown below, is a kind of shady business done by organized groups. And such activity is purely economic, business, and this is a feature of organized crime.

In view of the above, it should be concluded that the offenses related to the movement of goods / items across the customs border are considered in two aspects:

1) economic, where such offenses are specific types of illegal activity and are part of a shadow economy, which involves a purely criminal business (when it comes to the movement of objects that are restricted or prohibited in civil circulation) and illegal economic activity (illegal transactions with authorized goods). At the same time such offenses can be considered as tax violations, since the main purpose of the figure is to receive income in a minimal time by minimizing taxes and other obligatory payments;

2) legal, where violation of customs rules is a generic concept for a customs offense with a similar name and criminal offenses (regardless of which section of the Special Part of the Criminal Code is a specific act).

However, these approaches, when considered separately, do not allow us to form a comprehensive vision: in the economic context, the antisocial nature of such activity is ranked second; in the legal context, it is necessary to emphasize the subjective assessment of the degree of public danger of certain actions and, accordingly, the classification of offenses of different sectoral affiliation. Thus, until 2011, the Criminal Code of Ukraine contained criminal liability for the so-called "commodity smuggling". Decriminalization of the latter led to its normative "transformation" into "violation of customs rules".

For the purposes of this study, it is advisable to rely on the European Court of Human Rights approach (ECtHR) to determining the sectoral affiliation of an action for the purpose of applying the Convention on Human Rights when developing an approach to understanding offenses related to the movement of goods / items across the customs border and fundamental freedoms.

In its practice, the ECtHR has widely used an autonomous interpretation, which is that the ECtHR does not consider binding on itself the meaning which a term has within the legal system of a State party to the Convention. In doing so, the ECtHR constantly emphasizes the need to take into account the specificity, uniqueness of a particular situation in different states, if the issue of whether a certain right or a violation has been resolved, that is, the Convention necessarily interprets the view of the current conditions in the present state at the time consideration of a specific case. 
Thus, the ECtHR uses the so-called "Engel criteria": is the offense a criminal offense under national law; what character it is; what purpose is punished for it and how severe it is ${ }^{12}$.

Another aspect is the correlation between smuggling and other criminal offenses related to the movement of certain objects across the border (for example, Articles 199, 200, 203-1 of the Criminal Code). Please note that they are an internally heterogeneous group: these acts are criminal offenses, but if you say that the systemic features of smuggling are the place of crime (customs border) and the method (outside customs control or with concealment from customs control), then directly these signs in Art. 199, 200, 203-1 of the Criminal Code are not specified. However, according to the logic of committing such acts, their subjects cross the border in various ways, among which are the evasion of customs control or concealment from customs control. These acts are criminal offenses in the field of economic activity, which means that they not only encroach on the same object, but also that they are manifestations of shadow economic activity. However, if the carriage, transfer for the purpose of sale of counterfeit transfer documents, payment cards or their use or sale (Art. export-import disks for laser reading systems, dies, equipment and raw materials for their production, since such actions are illegal because, as an indirect purpose, there is an evasion of mandatory payments.

Therefore, one can speak of legal grounds for dealing with smuggling, other criminal offenses related to the illegal movement of goods / items across borders, and breaches of customs rules in a single criminological context. Their totality defines the concept of "offenses related to the movement of goods / items across the customs border". The economic aspect determines the nature of the actions related to the movement of any goods / items across the customs border.

In the modern world, the border is losing its isolation value and acquiring a number of new features, including economic. This clearly shows itself in cross-border cooperation. The main task of the latter is to establish effective economic interaction, to create a favorable foreign economic investment climate. Border territories are peripheral, their economic development opportunities are determined by their proximity to the state border, so they are somewhat limited. The development of human capital, the preservation of cultural heritage and ecological diversity are all components of the economic potential of the territories on both sides of the border ${ }^{13}$.

12 Справедливое судебное разбирательство в международном праве: юридический сборник / Бюро ОБСЕ по демократическим институтам и правам человека. Варшава, 2016. C. 79.

${ }^{13}$ Орловська Н. Кримінальні загрози безпеці транскордонного співробітництва. Вісник Начіональної академії Державної прикордонної служби Украӥни: Юридичні науки. 2018. Вип. 2. URL: file:///C:/Users/ASUS/Downloads/vnadpcurn_2018_2_3.pdf. (дата звернення: 11.12.2019). 
In this context, the nature of the threats is also thought to be predominantly economic. In this regard, offenses related to the movement of goods / items across the customs border have all the characteristics of a business: voluntary initiative nature of the activity, organization, availability of a plan for carrying out this activity, systematic profit, partnerships, a certain place in the shadow economy of both the region and the country as a whole. And the fact that this business is illegal does not change its economic nature.

The economic dimension of offenses related to the movement of goods / items across the customs border should be individualized depending on the individual's desire to satisfy his or her needs. Individuals who use illegally imported goods meet their needs to obtain the desired goods, while individuals who supply such goods seek to meet their income needs. Thus, for a certain part of the population living in the border areas, committing these offenses has become the nature of established "fishing". However, in any case, it is about meeting economic needs. Actually, the consumer value of the offense becomes only at the end of the "commodity chain", when the specific product gets to an individual.

The criminological component involves the analysis of the criminal situation: indicators and tendencies of socially dangerous behavior, peculiarities of types and forms of organized criminal activity in the relevant sphere, etc.

The economic-criminological dimension of the study of offenses related to the movement of goods / items across the customs border includes their consideration in the context of the shadow economy.

The shadow economy should be understood as an economic activity related to the misappropriation of a part or value of a property or a part of property by a person or a group of persons due to various kinds of distortion of objective information about cash flows and tangible assets, distortion of primary accounting data to confuse sources of income., as well as through lobbying through implementation of relevant legislation. In other words, it is the production, distribution, exchange and consumption of inventory that is uncontrolled by societies ${ }^{14}$.

In its form, the shadow economy is an illegal business that includes both illegal foreign economic transactions, in particular, and offenses related to the movement of goods / items across the customs border.

Therefore, offenses related to the movement of goods / items across the customs border are a shady business that also contains signs of criminal business. Like other types of shadow business, these socially dangerous acts play an ambiguous role in the economic system of any state: on the one hand,

${ }^{14}$ Сирбу К.Г., Куцемір І.В. Тіньова економіка: причини, види, наслідки. Економіка України. 2017. № 1. С. 56-63. 
they have a significant impact on the commodity mass, leading to demand disparities - supply shortfalls in the state budget of taxes and customs payments; on the other, it cannot be denied that they provide employment (main or secondary) in the border regions and the availability of goods at the market at a more favorable price for the consumer ${ }^{15}$.

This type of shady business is more profitable than legal activity because the benefits of tax evasion and tax evasion far outweigh the risk of being held accountable, which, frankly, is not a threatening factor for offenders today.

Thus, from all the above arguments, one can conclude that the purely economic nature of all offenses related to the movement of goods / items across the customs border. Such movement occurs, as a rule, for business purposes and not for personal consumption, across the customs border, subject to the violation of the established customs rules and procedures, and regardless of the value of the goods / items being moved.

\section{Offenses related to the movement of goods / items across the customs border as a cross-border business}

Considering the relativity of legislative assessments on the degree of public danger of shadow business, it seems appropriate to address organized crime as a form of shadow business in the area of moving goods / items across the customs border.

According to V.V. Lunyev, the understanding of organized crime is even less clear today than violent, self-serving or economic ${ }^{16}$. However, the opinion of Y.I. Gilinsky is correct that it is important not so much a formal definition of organized crime as an understanding of its nature, essence ${ }^{17}$.

Experts emphasize the existence of two main approaches to the definition of organized crime: the first relates to organized crime those crimes committed by groups with certain organizational characteristics that are judged by the judiciary; the second is that the relevant normative acts list the crimes the perpetrators of which are guilty of organized crime, although it is criticized by many criminologists. Types of organized crime are constantly changing, so it is impossible to predict a comprehensive list of them ${ }^{18}$.

\footnotetext{
15 Орловська Н. А. Зарубіжний досвід запобігання контрабанді(на прикладі Китаю). Актуальні проблеми кримінального права, процесу, криміналістики та оперативнорозшукової діяльності: тези II Всеукраїнської науково-практичної конференції (Хмельницький, 2 березня 2018 року). - Хмельницький : Вид-во НАДПСУ, 2018. С. 78-82.

16 Лунеев В. В. Преступность ХX века: мировые, региональные и российские тенденции / В. В. Лунеев. [изд. 2-е, перераб. и доп.]. М. : Волтерс Клувер, 2005. С. 35.

${ }^{17}$ Гилинский Я. И. Криминология. Курс лекций. СПб., 2002. С. 207.

18 Закалюк А. П. Організована злочинна діяльність:сутність та потреби нормативного визначення. Новий Кримінальний кодекс України: Питання застосування і вивчення: Матер. міжнар. наук.-практ. конф., м. Харків, 25-26 жовтня 2001р. К.; Х., 2002. С. 62.
} 
When it comes to organized crime in the context of an activity approach, the following features of organized crime are emphasized in the professional literature:

- fatigue, regularity and duration;

- careful planning of criminal activity;

- division of labor, differentiation into managers and subordinates (specialists of different level and specialization);

- creation of cash insurance stocks ("commons") used for the needs of a criminal organization.

But it remains unclear as to how correct it is that the concept of "organized crime" covers both the perpetrators and their activities. At the same time, the final ambiguity of the concept complicates the real estimation of the prevalence of the phenomenon, allows to take into account how the simplest forms of complicity are organized, leads to the leveling of the efforts of law enforcement agencies ${ }^{19}$.

It seems that the concept of organized crime as the most socially dangerous type of organized activity is subject to analysis as a combination of forms (certain structures) and types (certain offenses).

All types of organized criminal activity are economic in nature. Organized crime as a regulator of the shadow market performs a number of economic functions: meeting the needs of goods that were missing or lacking in the market, coordinating the activities of the entities of illegal economic activity, monitoring the implementation of agreements and out-of-process conflict resolution, job creation and attracting qualified specialists for the control structures, their protection, elimination of bureaucratic obstacles, financing and crediting, etc.

For domestic organized crime, active penetration into the sphere of economic activity is characteristic.

Organized crime in Ukraine has a dual nature - one of its components arose from the involvement of criminal organizations in the shadow and legal economies, and the second component originated directly in the legal economy - through the commission of economic offenses by legalized business entities. Many business entities are involved in illegal business activities and are directly interested in the functioning of criminal organizations, which is where the smugglers begin to cover, to increase their assets, strengthen their position in the market, eliminate competitors, reduce transaction costs, and so on.

19 Шостко О. В. Визначення поняття “організована злочинність” у зарубіжній кримінології. Вістник академії правових наук Украӥни. 2014/ № 1. С. 180-189. 
The peculiarity of domestic organized crime is that the shadow economy is the basis for its active expansion, not criminal activity.

When analyzing organized forms of offenses related to the movement of goods / items across the customs border, a systemic effect becomes apparent: the illegal movement of goods / items across the customs border of Ukraine enhances the criminal direction of economic development, which is manifested in the activation of organized criminal activities in the economy, exacerbated socio-economic situation in society, deterioration of the quality of life of the population and the emergence of disparities in spatial and regional development.

Thus, the organized forms of these offenses influence the strengthening of the criminal aspect of economic development, which results in widespread self-reproduction of socially dangerous behavior.

Shadow business is a manifestation of a systemic problem. Formally, there may be no organized criminal structure of which individual offenders are members. However, they represent residents of the territories who, by establishing corrupt links with law enforcement officers, are engaged in highly specialized shadow activity, having persistent self-motivation, incomeseeking intent, hiding activities from social control by establishing corruption ties. In view of this, the mechanisms and tactics of illegal activity are constantly being adjusted in accordance with the change of the rules of registration of import to the territory of Ukraine and export of goods from it, new measures are being developed to counteract the law enforcement agencies.

Thus, offenses related to the movement of goods / items across the customs border represent organized shadow activity (shadow business), the subjects of which can be both separate structures (eg organized criminal groups) and amorphous factions that formed in the border areas as a manifestation of the established form of employment of the local population.

Another aspect of the analysis of offenses related to the movement of goods / items across the customs border is the issue of their transnationality / cross-border.

Traditionally, it is noted that transnational character, inherent within the territory of one state, is inherent in these actions, unless free economic zones are introduced (i.e. no customs border is imposed), these offenses simply cannot be committed. The offenses related to the movement of goods / items across the customs border are committed by organized groups operating in several states.

The concept of transnationality was defined at the convention level in the UN Convention against Transnational Organized Crime (2000). Article 3 of this Convention is transnational in nature if it is committed: more than one 
State; in one State, but a substantial part of its planning, management or control preparation takes place in another State; in one state, but with the participation of an organized criminal group committing criminal activity in more than one state; in one state, but its significant consequences are manifested in another state ${ }^{20}$.

It follows that "transnationality" involves the question of criminalization of a particular act in several states, the preparation / commission / occurrence of the consequences of such a crime in more than one country, as well as the countries of origin and activity of the offenders. All this determines the jurisdiction of the "interested" states in bringing those responsible to justice. It is, in fact, the creation of a common criminal space. Otherwise, there will be no legal basis for recognizing certain acts as crimes and, as a consequence, for preventing these acts.

Thus, the issue of transnationality is, in fact, a problem of the place where the committed or completed crime is committed, with the obligation of multilateral criminalization and the penalization of appropriate actions.

Transnationality of a crime means going beyond the national criminal jurisdiction, which is generally delineated on state borders (because there are some cases of extending jurisdiction of the state to acts committed outside its borders). Against this background, the concept of transnational crime distinguishes the concept of transborder crime.

Thus, transnationality is a manifestation of the globalization of criminal activity, its worldwide distribution by specialization (activities). In particular, it is emphasized in the literature that the expansion of the scale of smuggling is based on economic interests as a result of globalization, which has replaced the confrontation between the two world systems. However, in this aspect, attention is drawn not to the nature of smuggling, which, as noted, is a crossborder crime, but to the factors behind the increase in the scope of smuggling activities. Globalization seems to affect the deterioration of the criminal situation not only at the supranational but also at the national level.

In turn, cross-border, in contrast, reflects the process of globalization mediating regional features of socially dangerous activities. Glocalization can be described as a domestic crime in general, as well as some of its structural elements that have a specific territorial link. This is most clearly manifested in cross-border crime

Thus, cross-border crime mediates transnational crime in crimes that reflect the socio-economic, political, demographic specificities of the territories on both sides of the border. It embodies local criminal features, with locality signifying regional rather than national level.

\footnotetext{
${ }^{20}$ Конвенція ООН проти транснаціональної організованої злочинності: Міжнародний документ від 15.11.2000. URL: http://zakon3.rada.gov.ua/ (дата звернення: 12.12.2019)
} 
On the basis of the above, it should be concluded that the offenses related to the movement of goods / items across the customs border, in their criminalized part, are transboundary crimes. For example, as regards smuggling in general and drug smuggling, in particular, as a cross-border issue, it is listed in the 2016-2020 Cross-Border Cooperation Program, one of the objectives of which is to prevent smuggling ${ }^{21}$.

If we talk about the totality of these offenses, they act as a cross-border shadow business, which in criminological terms leads to the involvement of broad sections of the population of the border territories in criminal activity through the formation of stable anti-social ties between citizens of different countries, the formation of corrupt representatives of schemes of corruption. authorities of neighboring states, etc. But it should be emphasized that crossborder crime has not yet become a factor of economic growth in any country. Cross-border organized crime is a kind of transnational organized crime.

Considering the systemic links of offenses related to the movement of goods / items across the customs border as a kind of shadow business, one should distinguish money laundering. Between them there is feedback (twoway). On the one hand, these offenses are a source and sector of the shadow economy, a prerequisite for the emergence of money laundering as a phenomenon, on the other, - laundering is a necessary component in the scheme of modern shadow business.

It should be noted that to characterize the relationship of offenses related to the movement of goods / items across the customs border, with the laundering of income in the literature, different terms are used: stage, stage, method, means, source, mechanism, process. For example, it is noted that "smuggling can serve as a source of criminal proceeds and a means of legalizing them"22. It is believed that the initial stage of money laundering involves the physical transportation of money (cash) abroad. The integration or return and legalization of money laundering is the final stage of this crime. T.A Dikanova, V.E. Osipov believes that "currency smuggling is usually the first stage in money laundering",23.

Offenses related to the movement of goods / items across the customs border are predicate for the laundering of proceeds of crime. In this connection, it is advisable to mention the statement: "considering the specific

${ }^{21}$ Про затвердження Державної програми розвитку транскордонного співробітництва на 2016-2020 роки: Постанова Кабінету Міністрів України від 23.08.2016 р. № 554. URL: http://zakon3.rada.gov.ua/ (дата звернення: 12.12.2019)

22 Контрабанда на “кордоні": інформація 3 Офіційного сайту Служби безпеки України // URL: https://ssu.gov.ua/ (дата звернення: 12.12.2019)

${ }^{23}$ Диканова Т. А., Осипов В. Е. Борьба с таможенными преступлениями и отмыванием “грязных" денег: Методическое пособие,- М.: ЮНИДАНА, Закон и право, 2000. 310 с. 
relationship of predicate crimes (major, secondary) with legalization, we can talk about the presence and functioning of direct (unilateral) and inverse (bilateral) relations between them" 24 .

Therefore, in case of illegal transfer (export) of capital committing such offenses acts as a way and stage of money laundering. However, part of the funds is illegally returned to Ukraine. This can be explained by the fact that in most foreign countries organized crime is concentrated mainly in the sphere of criminal business, and in Ukraine it operates in all the most profitable areas.

The problem of money laundering has become urgent in Ukraine precisely with the emergence and development of organized criminal activity, one of the manifestations of which is the offenses related to the movement of goods / objects across the customs border. Money laundering is the technological side of the existence of modern organized crime

Thus, from all of the above, it can be concluded that the offenses related to the movement of goods / items across the customs border and money laundering are closely interrelated, and there is a (two-way) relationship between them.

\section{CONCLUSIONS}

Thus, within the framework of the conducted research it is possible to reach the following conclusions.

Considering the unity of content and mechanism of socially dangerous activities related to the movement of goods / items across the customs border outside the customs control or to conceal from customs control under the generic concept of "offenses related to the movement of goods / items across the customs border" to combine smuggling, other criminal offenses related to the movement of goods / items across borders, violation of customs rules.

It can also be concluded that the offenses related to the movement of goods / items across the customs border are a shady business that also contains signs of criminal business. Like other types of shadow business, these socially dangerous acts play an ambiguous role in the economic system of any state: on the one hand, they have a significant impact on the commodity mass, leading to demand disparities - supply shortfalls in the state budget of taxes and customs payments; on the other, there is no denying that they provide employment (main or secondary) in the border regions and the availability of goods on the market at a more favorable price for the

24 Журавель В.В. Предикатний фактор у структурі елементів криміналістичної характеристики легалізації (відмивання) доходів, одержаних злочинним шляхом. Вісник правових наук. 2015 р. № 1(40). С. 128-136. 
consumer. And in such circumstances, the economic and criminological nature of these offenses is manifested.

These offenses are a highly profitable type of illegal business activity, the profit margin of which compensates economic agents material costs and moral damages from the risks of its implementation. Such a vision provides an opportunity to look at these offenses as a criminologically unified set of activities that intersects with transnational / cross-border economic organized crime.

It is important that the economic and criminological dimension of offenses related to the movement of goods / items across the customs border, in view of the activity approach in understanding socially dangerous behavior, makes it necessary to consider the problems of organized forms of shadow business: on the one hand, business cannot be disorganized; the organized nature of economic activity inherent in entrepreneurship; on the other hand, the criminological literature and regulatory acts present an approach to organized crime as a phenomenon, while at the same time the issues of organized forms of noncriminalized socially dangerous activity remain insufficiently explored.

\section{SUMMARY}

The article deals with a comprehensive study of the legal nature of offenses related to the movement of goods / items across the customs border, their current state and conceptual directions of prevention of this offense.

The idea of identifying offenses related to the movement of goods / objects across the customs border as a criminological group of offenses, including crimes and administrative offenses, which are mainly a cross-border shadow business. It has been found that the fact of committing offenses related to the movement of goods / items across the customs border has the character of business activities carried out by organized entities that are subjects of the shadow economy. The modern conceptual model of organized crime in the part of the analysis of amorphous structures as a modern type of criminal groups has been improved.

An in-depth understanding of the systemic links between the shadow business, organized crime and corruption in the area of offenses related to the movement of goods / items across the customs border as a type of crossborder shadow business.

\section{REFERENCES}

1. Bhagwati J., Hansen B. A Theoretical Analysis of Smuggling. The Quarterly Journal of Economics. Vol.87. № 2. (May, 1973). P. 172-187.

2. Sheikh M.A. Smuggling, production and welfare. Journal of International Economics. 1974. № 4. P. 355-364. 
3. Pitt M. Smuggling and price disparity. Journal of International Economics. 1981. № 11. P. 447-458.

4. Norton D.A. On the Economic Theory of Smuggling. Economica, New Series. Vol. 55. - № 217. (Feb., 1988). P. 107-118.

5. Chowdhury F.L. Smuggling, Tax Structure and The Need for AntiSmuggling Drive. Fiscal Frontier. Vol. VI. 2000. URL: http://www.answers.com/topic/faizul-latif-chowdhury.

6. Black Market Contraband Index. URL: http://www.havocscope.com/ products.htm.

7. Paulus I., Simpson C. Opportunity, Benefit, and Subjective Disposition: Determinants of Nonprofessional Smuggling. The Pacific Sociological Review. Vol. 24. № 3 (Jul., 1981). P. 299-327.

8. Брейтуэйт Д. Преступление, стыд и воссоединение / Пер. с англ. Н.Д. Хариковой; под общ. ред. М.Г. Флямера. М. : МОО Центр “Судебно-правовая реформа". 2002.

9. Визначення митної вартості та підтвердження країни походження: Офіційний портал Державної фіскальної служби України URL: http://poltava.sfs.gov.ua. (дата звернення: 10.12.2019)

10. Митний Кодекс України: Закон України від 13.03.2012 № 4495-VI. URL: https://zakon.rada.gov.ua/laws/show/4495-17/ed20120603

11. Кримінальний кодекс України: Закон України від 17.01.2002 № 4495-VI. URL: https://zakon.rada.gov.ua/laws/show/2341-14. (дата звернення: 10.12.2019)

12. Справедливое судебное разбирательство в международном праве: юридический сборник / Бюро ОБСЕ по демократическим институтам и правам человека. Варшава, 2016. С. 79.

13. Орловська Н. Кримінальні загрози безпеці транскордонного співробітництва. Вісник Національної академії Держсавної прикордонної служби України: Юридичні науки. 2018. Вип. 2. URL: file://C:/Users/ ASUS/Downloads/vnadpcurn_2018_2_3.pdf.

14.Сирбу К.Г., Куцемір І.В. Тіньова економіка: причини, види, наслідки. Економіка України. 2017. № 1. С. 56-63.

15. Орловська Н. А. Зарубіжний досвід запобігання контрабанді(на прикладі Китаю). Актуальні проблеми кримінального права, процесу, криміналістики та оперативно-розшукової діяльності : тези II Всеукраїнської науково-практичної конференції (Хмельницький, 2 березня 2018 року). Хмельницький: Вид-во НАДПСУ, 2018. С. 78-82.

16. Лунеев В. В. Преступность XX века : мировые, региональные и российские тенденции. изд. 2-е, перераб. и доп.. М. : Волтерс Клувер, $2005.35 \mathrm{c}$.

17. Гилинский Я. И. Криминология. Курс лекций. СПб., 2002. 
18. Закалюк А. П. Організована злочинна діяльність:сутність та потреби нормативного визначення. Новий Кримінальний кодекс України: Питання застосування і вивчення: Матер. міжнар. наук.-практ. конф., м. Харків, 25-26 жовтня 2001р. К.; Х., 2002.

19. Шостко О. В. Визначення поняття “організована злочинність” у зарубіжній кримінології. Вістник академії правових наук Украӥни. 2014. № 1. С. 180-189.

20. Конвенція ООН проти транснаціональної організованої злочинності: Міжнародний документ від 15.11.2000 / URL: http://zakon3.rada.gov.ua/

21. Про затвердження Державної програми розвитку транскордонного співробітництва на 2016-2020 роки: Постанова Кабінету Міністрів України від 23.08.2016 p. № 554. URL: http://zakon3.rada.gov.ua/

22. Контрабанда на “кордоні”: інформація з Офіційного сайту Служби безпеки України. URL: https://ssu.gov.ua/

23. Диканова Т. А., Осипов В. Е. Борьба с таможенными преступлениями и отмыванием “грязных" денег: Методическое пособие,- М.: ЮНИДАНА, Закон и право, 2000. 310 с.

24. Журавель В. В. Предикатний фактор у структурі елементів криміналістичної характеристики легалізації (відмивання) доходів, одержаних злочинним шляхом. Вісник правових наук. 2015 р. № 1(40). C. $128-136$.

Information about the authors: Palamarchuk G. V., Lecturer at the Department of Criminal Law, Process and Criminology, International Humanitarian University 33, Fontanska Road str., Odessa, 65009, Ukraine

Neledva N. V., Associate Professor at the Department of Criminal Law, Process and Criminology, International Humanitarian University 33, Fontanska Road str., Odessa, 65009, Ukraine 


\section{THE SUBJECTS OF THE ADMINISTRATIVE PROCESS}

\section{Popovich Ye. M.}

\section{INTRODUCTION}

The variety of administrative and procedural activities involves a significant number of its subjects. First of all, this is due to the fact that the administrative and procedural sphere covers almost all aspects of society.

In the General theory of law, the subject of law is a participant in public relations, endowed with rights and obligations and having two characteristics: social (participation in public relations as a separate, able to develop and implement a single will of a personified subject) and legal (recognition by legal norms of its ability to be a bearer of rights and obligations, to participate in legal relations).

Participants of administrative process can be characterized as citizens, other persons, collectives of citizens and organizations in the person of their representatives having the rights and certain duties allowing them to participate in consideration of administrative cases for the purpose of protection of the rights and legitimate interests or the rights and legitimate interests of the person, collective or organization which they represent, The necessity of differentiation of these concepts is explained by the fact that in the course of clarifying the General and characteristic inherent to each group of subjects, there is an opportunity to clarify important questions regarding the characteristics of the powers of leading actors, on the one hand, and the rights and duties of participants of process, on the other. This underscores the need for the leading actors of the process to protect and respect the rights and legitimate interests of its participants through their actions and decisions. Thus, the legal status of each of groups of subjects of administrative process becomes clear, possibilities of protection of the rights and legitimate interests of its participants expand.

\section{General characteristics of subjects of administrative procedure law}

In the General theoretical understanding, the subject is recognized (from the Latin subjectus - the one who is at the heart), the carrier of subjectpractical activity and knowledge (an individual or a social group), the source of activity aimed at the object.

In turn, in the theory of law, the subject of law is a person (natural or legal) that by law has the ability to have and implement directly or through a representative of the rights and legal obligations (that is, legal personality). 
Legal personality, which includes legal capacity and capacity, are endowed with both subjects of material administrative-legal relations and subjects of procedural administrative-legal relations ${ }^{1}$.

Administrative-procedural legal capacity is the ability to have legal rights and obligations in the administrative process. It is recognized for all citizens of Ukraine, foreigners, stateless persons, as well as for public authorities, other state bodies, authorities of the Autonomous Republic of Crimea, local authorities, their officials and officials, enterprises, institutions, organizations that are legal entities.

Administrative procedural legal capacity arises in citizens from the moment of their birth and is terminated by death. For legal entities, it arises from the moment of their creation and ends with their liquidation. To participate in the administrative process, in addition to the General administrative procedural legal capacity, it is also necessary to have a specific administrative procedural legal capacity, that is, in this particular case.

In order to personally participate in the consideration of an administrative case, it is not enough to have only administrative procedural legal capacity. Possession of administrative procedural capacity is also necessary for the participant of the case ${ }^{2}$.

Administrative-procedural capacity is the ability to personally exercise their administrative procedural rights and obligations, including to entrust the conduct of the case to a representative.

It belongs to individuals who: 1) have reached the age of majority; 2) are not recognized by the court as incapacitated.

It may also belong to individuals until the age of majority in disputes over public relations, in which they are in accordance with the law can independently participate.

Administrative procedural capacity is also vested in public authorities, authorities of the Autonomous Republic of Crimea, their officials and officials, enterprises, institutions, organizations (legal entities) $)^{3}$.

The component of the procedural capacity is the administrative-procedural delict worthiness, i.e. the ability of the subject to bear legal responsibility for the violation of administrative-procedural norms.

It is necessary to distinguish the concepts of "subject of administrative process" and "subject of administrative-procedural legal relations".

${ }^{1}$ Kuzmenko O. Course of administrative responsibility. Textbook. Kyiv: Yurinkom Inter, 2015. $568 \mathrm{p}$.

${ }^{2}$ The code of Ukraine on administrative offences dated 7 December 1984, No. 8073-x. URL: http://zakon4.rada.gov.ua/laws/show/80731-10

3 Administrative and legal protection of citizens ' rights: studies.-method. possib./ K. Afanasiev et al.; Lugan. state University EXT. cases to them. E. Didorenko. Lugansk : RIO LGUSD them. E. Didorenko, 2011. 279 p. 
The subject of the administrative process has the potential ability to enter into administrative-procedural legal relations. In a particular case, he may not be a party to these legal relations.

The subject of administrative-procedural legal relations is the actual participant of legal relations in the sphere of public administration, that is, he necessarily participates in them.

\section{Classification of subjects of administrative procedure law}

At present, the Institute of subjects of administrative process is seriously studied in the theory of administrative process. The theorists of the administrative process proposed different classifications of subjects of procedural legal relations, depending on what is invested by each of the theorists in the content of the administrative process. For example, S. Mahina proposed such a classification:

Three groups of subjects take part in the management process.

The first group - "endowed with their own powers (the party that governs) - the President, senior officials, the highest Executive authorities".

The second group is the subjects, which are subject to their own influence (controlled party). These include individuals and legal entities that are not endowed with their own powers in the field of management.

In the third group, the author includes subjects who simultaneously have their own powers and are under managerial influence. These are officials, state and municipal employees, structural units of public authorities, etc.

As for the administrative process as a form of coercive influence, as N.G. Salisheva notes, its subjects can be divided into two groups ${ }^{4}$.

The first group includes entities directly interested in the results of the legal process, whose interests and subjective rights are subject to protection by all procedural methods and techniques.

The second group includes the leading actors who perform their functions in the interest of others, for the purpose of a legal and reasonable decision on the case.

V. Sorokin divides subjects of administrative process on individualcitizens, foreign citizens, persons without citizenship; collective-Executive authorities, the enterprises, establishments, public associations, the state and municipal employees.

M. Tishchenko defines participants of process as citizens, other persons, collectives of citizens and the organizations represented by their representatives who are allocated with the rights and bear certain duties

${ }^{4}$ Administrative law: textbook / Y. Bytyak, etc.; the NAT. Yuri. Acad. Ukraine them. Yaroslav The Wise. Kharkiv: Pravo, 2010. 624 p. 
allowing them to participate in consideration of administrative cases for the purpose of protection of the rights and legitimate interests or the rights and legitimate interests of the persons represented by them, collectives of citizens or the organizations, and also to promote implementation of administrative process 5 .

It defines organizers (leading subjects) as subjects of administrative process acting for the purpose of conducting process, capable to make decisions on business on the state-power basis.

The group of organizers (leading subjects) is heterogeneous. The relation of this or that body (official) to law enforcement, i.e. the decision of business has essential value. The body (official) deciding the case leads not only at the decision stage. It has enough procedural possibilities to provide production at other stages: powers of procedural control, authorization of the procedural actions which are carried out by other leading subjects, ensuring execution of the decision. Of the organizers, he offers to call the wire. Therefore, other leading entities, depending on the degree of publicity of the legal case (jurisdictional, positive), are more or less dependent on the management.

In jurisdictional cases, the leading subjects are given greater freedom in the enforcement of power in relation to interested persons. in other proceedings, such leading subjects turn to the wire for the sanction of power influence. In the latter case, the procedural status of the leading actors approaches the status of stakeholders.

Finally, all the leading actors can be attributed to the composition of the participants, since the implementation of compulsory procedural actions in the vast majority of cases is carried out with the approval of the leadership.

Therefore, the scientist proposes to divide the subjects of production into groups and participants. And the latter - on the leading actors, stakeholders and persons contributing to the consideration of the case.

Wire. The subject of the process is the management body as a whole (for example, the Ministry of economic development and trade of Ukraine). Procedural functions of the Ministry in production are carried out by its management, legal management, other divisions. At the same time, the Deputy Minister acts as a guide in the case. It should be considered a legal form realist procedural functions leads to such a level of administrative organization as a Ministry.

At the same time, the functions of the Commission can rely not only on the bodies on behalf of which their senior officials act. An official to whom such a right is specifically delegated may also ensure the proceedings in an

${ }^{5}$ Kolpakov V. Administrative-tort process: studies. benefit. / Kolpakov V., Gordeev V. Kharkiv: Kharkiv legal, 2012. 227 p. 
administrative case. Therefore, the leadership should be understood as bodies and officials ${ }^{6}$.

The judge performs procedural actions that are of a key nature during a certain stage, the previous stage of the decision of the case. As a rule, it is the expert who appoints the examination, demands evidence from interested parties, communicates with the authorities of foreign countries. If the judicial or administrative authorities of one party to an international Treaty, in connection with their consideration of violations of customs legislation and regulations, request it, the customs authorities of the other party to such Treaty may authorize their employees as experts and witnesses in such judicial or administrative proceedings.

However, some procedural actions cannot be committed or authorized even by wire. It is a question of restriction of the rights and freedoms of citizens which can be applied only by court, or about measures which can be used only by the Central office of system of a certain service.

First, administrative detention. It is applied judicially in order to:

1) the transfer of a person to a competent authority established by law on the basis of a reasonable suspicion that he has committed an offence or if there are reasonable grounds to consider it necessary to prevent him from committing an offence or fleeing after it has been committed;

2) the prevention of the illegal entry of a person into the country or the detention of a person to whom measures are taken for the purpose of deportation or extradition;

3) application of Supervisory measures of educational character to the minor or his lawful detention of the minor for the purpose of its delivery to the competent authority established by the law; 4) prevention of distribution of infectious diseases, lawful detention of mentally ill, alcoholics, addicts or vagrants.

Secondly, according to part 1 of article 30 of the Constitution of Ukraine, inspection of objects in housing or other possession of a person is applied in court.

Third, only a higher authority (the Central office of the Ministry, another Central Executive authority) decides to extend the terms of production (for example, the extension of the terms of execution of the decision on the land dispute).

V. Kolpakov distinguishes five groups of subjects of administrative process: 1) citizens; 2) Executive and administrative bodies and structural parts of their apparatus; 3 ) associations of citizens and their bodies, and also

${ }^{6}$ Kuzmenko O. Course of administrative responsibility. Textbook. Kyiv: Yurinkom Inter, 2015. 568 p. 
bodies of self-organization of the population which have administrative and procedural legal personality; 4) civil servants, employees of local governments, officials, are allocated with administrative and procedural rights and duties; 5) other state bodies and their officials ${ }^{7}$.

A special place among them is occupied by citizens.

They, first, they are the bearers of rights and obligations (including administrative and procedural) in any branch of public administration (economic, socio-cultural, administrative, political);

- secondly, the specificity of the General legal status of citizens generates in all other subjects of the administrative process the obligation to ensure compliance with their rights;

- thirdly, unlike other subjects, citizens are not competent to solve administrative cases (if not endowed with special powers, but in this case they already belong to another category of subjects);

- fourthly, citizens cannot enter into administrative and procedural relations directly with each other.

Executive and administrative bodies as subjects of the administrative process are characterized primarily by the fact that they solve individual cases. However, the administrative and procedural legal personality of Executive and administrative bodies varies. It is divided into General, branch and special.

General legal personality are those bodies whose competence includes the solution of a wide range of cases, regardless of their sectoral competence. These include, for example, local state administrations, bodies of local self-government.

Branch legal personality are bodies whose tasks include the resolution of cases within the industry. These are, for example, departments, services, departments of ministries.

Special legal personality have bodies created specifically to solve a narrow range of cases. For example, the administrative Commission of the district state administration.

The relevant normative acts determine the administrative and procedural legal personality of officials, civil servants, employees of local selfgovernment bodies. Its features are due to two circumstances ${ }^{8}$ :

- first, it is important that civil servants belong to a certain category of managers or specialists (the legal personality of a Manager is broader than that of a specialist);

7 ComSoc A. Administrative process of Ukraine: textbook. no./ ComSoc A. T., V. Bevzenko R. Miller. Kiev : A Precedent, 2007. 531 p.

${ }^{8}$ Scientific and practical commentary of the Code of Ukraine on administrative offences / G. Kalyuzhny, N. Inshin, I. Shopina, etc. - fifth Edition, with amendments and additions as of September 10, 2013 Kyiv: Alerta, 2013. 976 p. 
- secondly, the content of official rights and duties plays a significant role. Therefore, the head of the district state administration and the head of Department of the Ministry belong to one category-the third, but, it is clear that their legal personality different.

Other state bodies and officials provided for by law have special administrative and procedural legal personality.

So, district (city) judges individually consider a number of cases on administrative offenses (Art. $221 \mathrm{CAO}$ ), in bodies of Prosecutor's office production on complaints and statements of citizens is conducted.

The Ukrainian Parliament Commissioner for human rights exercises parliamentary control over the observance of constitutional rights and freedoms of man and citizen and the rights of everyone in Ukraine and has the right to invite officials and officers, citizens of Ukraine, foreigners and stateless persons for verbal or written explanations regarding circumstances that are verified by the case.

In the literature the administrative-procedural legal personality of such state bodies as the national security and defense Council of Ukraine, the Central election Commission and others is considered.

Given the current trends in the development of administrative-procedural legislation and theoretical studies of scientists- system of subjects of administrative process can be presented as follows:

- Citizens, foreign citizens and stateless persons;

- State bodies, enterprises and institutions;

- Public associations and other non-governmental organizations, enterprises and institutions;

- Civil servant;

- Employees of public associations and other non-state formations.

Citizens, foreign citizens and stateless persons form the most numerous group of subjects of administrative process. They act in the administrative process as:

- persons who have initiated an administrative case before the body entitled to its decision in connection with the exercise of their rights or performance of duties;

- administrative dispute, have declared in the body authorised to consider administrative proceedings, requirements for the protection of violated or disputed rights, or the party to whom a claim to the authority about the violation or contesting its rights applicant;

- third parties, that is, a person who has made an independent claim on the subject of the dispute, has not made such a claim, but joined the requirements of one of the parties;

- authorized representative, unless otherwise provided by law; 
- the person brought to administrative responsibility;

- the victim, i.e. the person to whom moral, physical or material harm is caused by an administrative offense;

- a person protecting the rights and interests of others;

- witness, interpreter, expert.

In each of these cases, the legal status of a citizen as a participant in the administrative process has its own specifics, which is due to the role that the citizen performs in the process. However, the legislation enshrines the General procedural rights and obligations, recognizing the administrativeprocedural legal capacity and administrative-procedural capacity of citizens.

State bodies, enterprises and institutions. They have a special role in the sphere of public-legal relations. Legislative (representative) authorities, Executive authorities, courts, Prosecutor's office are to some extent endowed with the rights to resolve specific administrative cases.

State bodies, first of all Executive authorities, can act in the administrative process as:

- bodies considering and deciding an administrative case;

- bodies that initiate proceedings in connection with the exercise of their functions before the body entitled to its resolution;

- parties to an administrative dispute, third parties;

- bodies protecting the rights and legitimate interests of other persons (bodies, institutions, organizations).

State enterprises, institutions, associations and other legal entities may participate in the administrative process on the same grounds as state bodies.

Public associations and other non-governmental organizations, enterprises and institutions may act in the administrative process as: non-state formations (organizations, etc.), which initiated an administrative case in connection with the exercise of their functions before the body that has the right to solve it; parties to an administrative dispute; third parties; organizations that protect the rights and interests of other persons; organizations that solve an administrative case in cases and within the limits established by law.

Civil servant. As subjects of administrative process employees can act as: the official who considers and makes decisions on administrative business; the official who initiated administrative business in connection with implementation of the functions assigned to it before the body having the right to its permission; the parties of administrative legal dispute; the representative of state body, the state enterprise, establishment; the third persons; the person brought to disciplinary or administrative responsibility.

Employees of public associations and other non-state formations. Nonstate employees may act in the administrative process as: an employee who initiated an administrative case in connection with the exercise of official 
functions before a body entitled to its resolution; parties to an administrative dispute; a representative of a public Association or other non-state formation, third parties; an employee who considers and makes decisions on an administrative case in cases provided for by law; the person brought to administrative responsibility in the cases specified in the law ${ }^{9}$.

In cases stipulated by the legislation, representatives of public associations, organizations, for example, trade unions, consumer protection societies and the like may participate in the administrative process.

\section{Features of the administrative-procedural status of citizens}

Citizens, first of all, are carriers of the rights and duties (including administrative and procedural) in any branch of the public-administrative sphere (economic, socio-cultural, administrative, political);

- secondly, the specificity of the General legal status of citizens generates in all other subjects of the administrative process the obligation to ensure compliance with their rights;

- thirdly, unlike other subjects, citizens are not competent to solve administrative cases (if they are not endowed with special powers, but in this case they already belong to another category of subjects);

- fourthly, citizens cannot enter into administrative and procedural relations directly with each other.

The administrative-procedural status of a citizen should be considered in a broad and narrow sense, which relate to each other as a whole and a part.

In a narrow sense, it is a set of legal qualities that the state confers on a citizen. First of all, these are rights and obligations. The attitude of the state towards citizens in the sphere of administrative law and procedure is also expressed through other legal categories, such as legal guarantees of the rights, freedoms and obligations of citizens. In other words, everything that legislates the position of a citizen in society, mediates the types of ties and relations between the state and the citizen, should be understood as the legal status of a citizen in a broad sense.

Thus, in a narrow sense, the administrative-procedural status of a citizen is a set of legal possibilities of citizens regulated by administrative-procedural norms as carriers of subjective rights and obligations to participate in administrative-procedural activity.

In a broad sense, the administrative-procedural status of a citizen is a set of all legal means fixed in the administrative-procedural norms, with the help of which the position of a citizen in the administrative process is determined.

9 Administrative and legal protection of citizens ' rights: studies.-method. possib./ K. Afanasiev et al.; Lugan. state University EXT. cases to them. E. Didorenko. Lugansk : RIO LGUSD them. E. Didorenko, 2011. 279 p. 
It is advisable to allocate the following types of administrative and procedural status of a citizen: General administrative and procedural status of citizen, which is characteristic for all types of industries; special (special) the status of specific industries; single administrative and procedural status of a particular participant in the particular circumstances. Realization of the individual status of the citizen is connected with stages, stages of productions and separate procedural actions.

Illustrating this provision, we note, for example, that absolutely for all citizens participating in the process, the law provides for the right to receive information, at the constitutional level, the right to appeal in court the actions of officials. These rights are characteristic of the entire administrative process, and therefore, they can be attributed to the General administrative-procedural status of a citizen, analyzing which, we come across a special procedural status. Thus, in the proceedings on administrative offenses, we observe a set of procedural rights and obligations characteristic of this production and enshrined by the legislator in an independent section of the administrative Code.

As elements of the administrative-procedural status of a citizen include: a) administrative-procedural rights; b) administrative-procedural legal capacity; c) administrative-procedural capacity; d) administrative-procedural freedoms; e) administrative-procedural duties; e) administrative-procedural legitimate interests.

Through the mechanism of subjective rights, a broader category of human and civil rights is realized.

Administrative and procedural rights of citizens can be divided into groups (types). Depending on the stage of the administrative process: the rights associated with the possibility of initiating an administrative process on the initiative of the citizen (in particular, the right to receive specific information from the competent authorities, the right to submit an application, etc.); the rights associated with informing the citizen about the reasons and purpose of involving him in the administrative process initiated by other entities. In particular, these are the rights to familiarize with the case materials, to obtain an explanation of the grounds for applying coercive or administrative preventive measures to it; the rights that enable a citizen to influence the course and results of the administrative process. As the largest group, administrative procedural rights are most fully enshrined by the legislator, although to a greater extent this applies to jurisdictional proceedings. For example, the right to give explanations, to present evidence, to file petitions, etc; the rights connected with possibility of the appeal by the citizen of actions and decisions of competent authorities and officials. 
Depending on the possibility of personal exercise of administrative and procedural rights by a citizen, it is possible to distinguish the rights that a citizen realizes independently; the rights that a citizen delegates to other persons (legal representatives) in accordance with the law.

Finally, the method steps include: administrative procedure law, the implementation of which the citizen should make certain actions, for example to declare the petition for granting translator; administrative procedure law, the implementation of which the citizen does not need to actually act (e.g. the right to consideration of the application within the statutory period specific).

Administrative-procedural rights of the second type, as a rule, are not fixed in normative-legal acts. In most cases, they arise from the procedural obligations of other subjects of the administrative process.

It is obvious that the ratio of administrative and procedural rights of citizens and their respective responsibilities of the competent authorities and officials is the most important factor in the reality and effectiveness of the Arsenal of procedural rights of the individual ${ }^{10}$.

Administrative-procedural legal capacity, as a rule, is associated with the implementation of procedural rights of citizens in specific legal relations. But, a number of administrative and procedural rights are enshrined directly in the sources of law, regardless of specific legal relations (an example of such a right is the right to appeal to the Executive authorities for assistance in the implementation of subjective rights). Implemented in accordance with the will of the citizen, they give rise to certain legal relations. In connection with these legal relations, the citizen has procedural rights due to them.

\section{Administrative and procedural status of individual subjects of the administrative process}

In the existing classifications of subjects of procedural legal relations, proposed by theorists of administrative process, all subjects of administrativeprocedural activity are taken into account.

However, the proceedings on administrative offences have a certain list of subjects whose functions and competence are clearly defined by the norms of the Code of Ukraine on administrative offences and other legal acts of Ukraine.

According to this, according to the nature of the procedural status of the subjects of the said proceedings can be divided into three groups: 1) the subjects who decide the case (subjects of jurisdiction); 2) the subjects against whom the case is decided (interested subjects); 3 ) auxiliary participants in the proceedings (disinterested subjects).

${ }^{10}$ Kuzmenko O. Administrative justice in Ukraine: textbook. Kyiv: Atika, 2007. 156 p. 
The first group always includes state bodies and their officials.

The second group can include almost any subjects, both bodies and persons.

The third includes witnesses, victims, experts, translators, lawyers and the like. The specific list of participants in administrative-procedural relations depends on the type of administrative proceedings.

Subjects of administrative jurisdiction are public administration bodies and their officials who carry out administrative and jurisdictional activities related to the decision of a particular case of an administrative offense and the issuance of the relevant law enforcement act.

The Executive bodies of councils can be referred to the public bodies exercising jurisdictional activity, because, in accordance with section II of the Constitution of Ukraine and article 5 of the Law "on local self-government in Ukraine", these are components of the local self-government system in Ukraine, which satisfy the public interests. Although the Executive bodies of councils can also be defined as local self-government bodies, there are no administrative commissions in their list (article 5 of the Law).

Thus, the system of subjects of administrative jurisdiction includes authorized bodies (officials) of public authority, court (judges) (in terms of resolving cases of administrative offenses), bodies and structures of local selfgovernment.

The interested subject - the person brought to responsibility, the victim and their legal representatives (parents, adoptive parents, guardians, Trustees, lawyers). Unlike the subjects of the first group, none of the representatives of this group does not enjoy authority ${ }^{11}$.

The personality of the offender is characterized primarily by the signs inherent in the subject of the offense (age, sex, official, social status, illegal behavior in the past), as well as behavior in the workforce and at home, attitude to family, colleagues, school, and the like. All these circumstances must be established by the body (official), considering the case, to have a full idea of the identity of the offender.

The rights of stakeholders should include:

1. The right to get acquainted with the materials of the case, except for those with limited access. Such materials include official documents of the leading entity confidential materials. The confidential nature of the information must be recognized by the lead entity or wire. Information may be considered confidential if its disclosure may cause harm to the interested

11 Course of administrative law of Ukraine: Textbook / V. Kolpakov, O. Kuzmenko, I. Pastukh, V. Sushchenko, etc. 2nd ed., processing. and extra. Kyiv: Yurinkom Inter, 2013. $872 \mathrm{p}$. 
person who provided it, or / and other participants in the process. A leading entity may deny access to confidential information if it is determined that a person has divulged sensitive data.

2. The right to produce evidence. 3. The right to invite experts and provide expert opinions.

3. The right to submit petitions, oral and written explanations (objections), statements.

4. The right to object to the petitions of other interested persons.

7. The right to participate in the proceedings conducted by the leading actors (in particular, the preparation of an act of offense, including in hearings held at the stage of investigation).

8. The right to appeal the decision.

Responsibilities of stakeholders are: 1) conscientiously exercise their corresponding rights; 2) timely provide to its leading entity the necessary information; 3) as jurisdictional, and positive processes sometimes provides for the obligation of the presence on stage of the case.

Responsibility of interested persons for non-performance of duties:

1) accelerated adoption of the final decision, in fact, less favorable for the interested person (if the interested person evades cooperation with the leading entity-does not give access to information, does not provide it in a timely manner, hinders the investigation).

Applicant. The applicant is the person who filed the application, the body (official) makes representations about the violation of the legislation.

Disinterested subjects - persons and bodies that facilitate the implementation of the proceedings: a lawyer, witnesses, experts, specialists, translators, witnesses and the like.

A lawyer or other specialist in the field of law, who has the right to provide legal assistance in person or on behalf of a legal entity, may get acquainted with the case materials, submit petitions, on behalf of the person who invited him, on her behalf, bring complaints against the decision on the case. His powers to participate in the consideration of the case are certified by the relevant document confirming the right to provide legal assistance ${ }^{12}$.

Witness. A witness is a person about whom there is evidence that he knows any circumstances to be established in the case under consideration.

The witness participates in exceptional cases. A civil servant as an impartial subject of law unilaterally fixes the circumstances of the case. However, it is necessary to provide for a wider involvement of witnesses to record the circumstances that are the leading actors. Interesting is the combination of the

${ }^{12}$ Kolpakov V. Administrative-tort process: studies. benefit. / Kolpakov V., Gordeev V. Kharkiv: Kharkiv legal, 2012. 227 p. 
status of a witness and an interested person. Thus, when considering a case of violation of the legislation on protection of economic competition, the Antimonopoly Committee bodies receive explanations from any persons who are not participants in the case) at their request. And in the other case, the law defines the circle of such interested witnesses. National commissions on regulation of natural monopolies, when making decisions on such regulation, take into account information on the activities of a natural monopoly subject provided by consumer associations, natural monopoly subjects, and other interested parties. This does not raise the question of admission to the production of such an interested witness. For example, on personal reception citizens can come with relatives, others, at will persons who have direct relation to the questions raised in the statement of such citizen. At the same time, the term "witnesses" is rarely used due to the fact that the vast majority of disinterested persons receive information due to their social status. First of all, we are talking about officials. But with regard to citizens, it is really worth using the term witnesses.

The duties of the witness include: 1) to appear at the call of the leading subject or the wire; 2) to give a truthful explanation; 3) to report the circumstances known to him in the case and answer the questions posed".

Expert. The expert is appointed by the body (official) considering the case when there is a need for special knowledge. Examination can be carried out by an expert of a special institution, individual experts, expert commissions. Thus, the Antimonopoly legislation provides for the granting by the Cabinet of Ministers of Ukraine of permission for concerted actions only in the presence of the conclusion of the Commission from among independent experts with a positive assessment of the consequences of such actions'.

To the rights of the expert are: 1) the right to request him to review the case materials relating to the subject of examination if it is necessary to give an opinion; 2) the right to refuse to give conclusions if provided materials are not enough or not necessary knowledge to complete the examination; 3 ) the right to request additional materials necessary to give an opinion; 4) to put the person concerned, the witness questions which relate to the subject of examination, to be present at the resolution of the case.

The duties of the expert include: 1) the duty to be responsible for refusing to give an opinion without good reason; 2) the duty to be responsible for the disclosure of information with limited access".

Others (translators, witnesses) are needed to consolidate evidence or provide the necessary conditions for administrative proceedings.

Translator. This participant in the proceedings is engaged by the leading entity (wire) at the request of the person concerned, who does not speak the language in which the proceedings are conducted, or on his own initiative in the interests of ensuring a complete and accurate translation, which he is entrusted. 
The translator, who is appointed in case of need by the body (official) considering the case, is obliged to appear at the call of the latter and make the translation fully and accurately entrusted to him.

Witnesses. An adult person who is not interested in the outcome of a case and participates in the proceedings to certify its fact, progress and results in cases established by the SCCR is understood ${ }^{13}$.

A witness has the right: 1) to know the conduct of procedural actions he is involved, who runs it and who participates; 2) to do about procedural acts in which he participates, the statements and comments that shall be included in the minutes of the procedural action; 3 ) the transcript of the procedural action in which he participated, and to require corrections and additions; 4) to sign the minutes of the procedural action in the part, which reflects perceived personally the circumstances;

5) to receive compensation for the expenses incurred by him related to participation in the proceedings. A witness is obliged: 1) to report on the claim of an official of the body conducting administrative process, information about the relationship of persons in administrative proceedings; 2) certify with his signature the minutes of the procedural action, the fact that the production of this action, its progress and results; 3 ) observe the procedure in the production of procedural actions; 4) to obey the lawful orders of the officers of the body conducting administrative process.

The defendant may be questioned as a witness about the circumstances related to the proceedings in which he took part.

Specialists. These include specialists of non-governmental organizations operating in the field, subjected to individual legal regulation (for example, specialists of self-regulatory organizations).

Another type of specialists are specialists who simultaneously present their views on the legal qualification of circumstances. The participation of such specialists is necessary to obtain reasonable assessments and conclusions about the legality of the actions of officials in respect of whom an internal investigation is appointed.

This group also includes public organizations, labor collectives, administration at the place of work, study or residence of offenders. They cooperate with the state authorities, helping them in the implementation of educational work. In some cases, such participants in the proceedings must be informed about the administrative measures taken against the perpetrators. They can apply for mitigation of administrative responsibility. A person who has committed an offense may be released from administrative responsibility

${ }^{13}$ Kolpakov V. Administrative-tort process: studies. benefit. / Kolpakov V., Gordeev V. Kharkiv: Kharkiv legal, 2012. 227 p. 
with the transfer of materials for consideration by a public organization or a labor collective.

Thus, the proceedings in cases of administrative violations has a wide range of subjects, which are guaranteed the relevant rights and freedoms. Detailed regulation of relations between subjects of jurisdiction and participants of the specified production is a guarantee of objective resolution of legal disputes which arise, in exact accordance with the legislation. The easier and bezkonfliktnishe relationship between a citizen and the state in the face of its bodies and officials, the calmer and more secure he feels, resulting in increased law-abiding, respect for the state and its bodies, increases the authority of the latter.

\section{CONCLUSIONS}

The concept of the subject of administrative process. Classification of subjects of administrative process. Features of administrative legal personality of individuals and legal entities, civil servants (employees of local governments) and officials who are endowed with administrative and procedural rights and duties (administrative and procedural legal capacity, administrative and procedural capacity). General characteristics of administrative-procedural legal personality of other subjects of administrative process. The distinction between the concepts "subject" and "participant" of the administrative process.

\section{SUMMARY}

In the General theoretical understanding, the subject is recognized (from the Latin-the one who is at the heart), the carrier of subject-practical activity and knowledge (an individual or a social group), the source of activity aimed at the object.

In turn, in the theory of law, the subject of law is a person (natural or legal) that by law has the ability to have and implement directly or through a representative of the rights and legal obligations (that is, legal personality).

Legal personality, which includes legal capacity and legal capacity, is vested in both subjects of material administrative-legal relations and subjects of procedural administrative-legal relations.

Administrative-procedural legal capacity is the ability to have legal rights and obligations in the administrative process. It is recognized for all citizens of Ukraine, foreigners, stateless persons, as well as for public authorities, other state bodies, authorities of the Autonomous Republic of Crimea, local authorities, their officials and officials, enterprises, institutions, organizations that are legal entities. 
Administrative procedural legal capacity arises in citizens from the moment of their birth and is terminated by death. For legal entities, it arises from the moment of their creation and ends with their liquidation. To participate in the administrative process, in addition to the General administrative procedural legal capacity, it is also necessary to have a specific administrative procedural legal capacity, that is, in this particular case.

In order to personally participate in the consideration of an administrative case, it is not enough to have only administrative procedural legal capacity. Possession of administrative procedural capacity is also necessary for the participant of the case.

Administrative-procedural capacity is the ability to personally exercise their administrative procedural rights and obligations, including to entrust the conduct of the case to a representative.

The administrative process is characterized by a variety of subjects. As parties (participants, subjects) in the administrative process are legal entities and individuals; Executive and administrative bodies of the state and local self-government; administrations of enterprises, institutions, organizations and public organizations; political parties and bodies of public initiative; Association of citizens and ordinary citizens, as well as foreigners and stateless persons and others.

The analysis of the whole array of participants of administrativeprocedural relations allows us to identify five groups of subjects of administrative process:

1) citizens;

2) Executive and administrative bodies and structural parts of their apparatus;

3) Association of citizens and their bodies, as well as bodies of selforganization of the population having administrative and procedural legal personality;

4) civil servants and officials vested with administrative and procedural rights and duties;

5) other state bodies and their officials.

\section{REFERENCES}

1. Administrative justice. Administrative proceedings: studies.benefit. / T. Kolomoets, G. Gulevskaya, R. Sinelnik. Kiev: Istina, 2007. 152 p.

2. Administrative law: textbook / Y. Bytyak, etc.; the NAT. Yuri. Acad. Ukraine them. Yaroslav The Wise. Kharkiv: Pravo, 2010. 624 p. 
3. Administrative law of Ukraine. Vol. 1: General administrative law textbook: in 2 volumes / Galunko V. et al. Kherson: PJSC "Kherson city printing house", 2011. $320 \mathrm{p}$.

4. Administrative procedural (judicial) law of Ukraine: Studies. / Odessa national law Academy / S. Kivalov (Ed.). Odessa: Legal literature, 2017. $312 \mathrm{p}$.

5. Administrative and legal protection of citizens ' rights: studies.method. possib. / K. Afanasiev et al.; Lugan. state University EXT. cases to them. E. Didorenko. Lugansk : RIO LGUSD them. E. Didorenko, 2011. 279 p.

6. Administrative procedural law of Ukraine: Textbook. / Edited by O. Kuzmenko. Kyiv: Atika, 2007. 416 p.

7. Bandurka O. Administrative process: Textbook for the University / O. Bandurka, M. Tishchenko. Kiev: Litera LTD, 2002. 286 p.

9. Demsky E. Administrative procedural law of Ukraine: studies. no. I E. Demsky. Kyiv: Yurinkom Inter, 2008. 496 p.

10. Kolpakov V. Administrative responsibility (administrative-tort law): Textbook / V. Kolpakov. Kyiv: Yurinkom Inter, 2008. 256 p.

11. Kolpakov V. Administrative-tort process: studies. benefit. / Kolpakov V., Gordeev V. Kharkiv: Kharkiv legal, 2012. 227 p.

12. ComSoc A. Administrative process of Ukraine : textbook. no. I ComSoc A. T., V. Bevzenko R. Miller. Kiev : A Precedent, 2007. 531 p.

13. Kuzmenko E. in Administrative-procedural law of Ukraine: textbook. Kyiv: Atika, 2007. 416 p.

14. Kuzmenko O. Administrative justice in Ukraine: textbook. Kyiv: Atika, 2007. 156 p.

15. Kuzmenko O. The Course of the administrative process: proc. benefit. NATs. Acad. EXT. cases'. Kyiv: Yurinkom Inter, 2014. 207 p.

16. Perepelyuk V. Administrative process. General part: Tutorial. Kyiv: center of educational literature, 2004. $367 \mathrm{p}$.

17. Administrative law: textbook / NU "YUAU im. Yaroslav the Wise"; for zag. ed: Y. P. bytyak, V. Garashchuk, V. Zui. 2nd ed., Rev. and additional. Kharkiv: Pravo, 2013. 56 p.

18. Administrative procedural law: studies. no. / Dnepropetr. state University EXT. del; for zag. ed. Kharkiv: Pravo, 2013. $352 \mathrm{~s}$

19. The code of Ukraine on administrative offences dated 7 December 1984, No. 8073-x URL: http://zakon4.rada.gov.ua/laws/show/80731-10

20. Course of administrative law of Ukraine: Textbook / V. Kolpakov, O. Kuzmenko, I. Pastukh, V. Sushchenko, etc. 2nd ed., processing. and extra. Kyiv: Yurinkom Inter, 2013. 872 p. 
21. Scientific and practical commentary of the Code of Ukraine on administrative offences / G. Kalyuzhny, N. Inshin, I. Shopina, etc. - fifth Edition, with amendments and additions as of September 10, 2013 Kyiv: Alerta, 2013. $976 \mathrm{p}$.

22. Kuzmenko O. Course of administrative responsibility. Textbook. Kyiv: Yurinkom Inter, 2015. 568 p.

\section{Information about the author:}

Popovich Ye. M.,

Doctor of Law, Professor,

Professor at the Department of Administrative,

Criminal Law and Procedure, International University of Business and Law 37-A, 49 HGD str., Kherson, 73040, Ukraine 


\section{PROCEEDINGS FOR CONSIDERATION OF CITIZEN'S APPEALS}

Predmestnikov O. G.

\section{INTRODUCTION}

The development of the rule of law in Ukraine is inextricably linked with the strengthening and development of subjective rights and freedoms of citizens. In the implementation and protection of such rights and freedoms, one of the most important places is occupied by proposals, applications and complaints of citizens. At the same time, they play a role that guarantees the rule of law in public administration. The level of compliance with the rule of law in the state directly depends on the participation of law-abiding citizens in activities to support it. On the other hand, it is impossible not to agree that the presence of a large number of complaints about the actions of employees of the Executive apparatus is an alarming symptom, forcing us to closely analyze the state of Affairs in this apparatus and take measures to improve its work. One of the key areas of strengthening the rule of law is to improve the existing legislation, primarily administrative and procedural rules governing the exercise and protection of subjective rights and freedoms of citizens.

The main sources of information needed to address issues of state, economic and socio-cultural construction should include citizen's appeals as one of the most important means of exercising and protecting their rights. Appeals can relate to a variety of aspects of life and society-from the national interests of a particular person.

\section{The concept and types of appeals of citizens}

The appeal of citizens is considered as one of the ways to ensure legality and discipline in public administration. The attribution of this image to those by which it is possible to influence the state of law and discipline in the state is extremely important. The fact is that citizens ' appeals should be perceived as: a) a means of protection against violations of their rights, freedoms and legitimate interests by Executive authorities; b) the possibility of real influence on the activities of Executive authorities and officials; c) the opportunity to get a positive result for the citizen without the use of special legal knowledge for the registration of certain documents; d) the indicator of the formation of civil society ${ }^{1}$.

\footnotetext{
${ }^{1}$ Kuzmenko O. Course of administrative responsibility. Textbook./ed. Kuzmenko O. Kiev: Yurinkom inter, 2015. 568 p.
} 
Proposal (remark)-citizens ' appeal, where they Express advice, recommendation on the activities of state authorities and local selfgovernment bodies, deputies of all levels, officials, as well as opinions on the settlement of public relations and living conditions of citizens, improvement of the legal basis of state and public life, socio-cultural and other spheres of activity of the state and society.

Application (petition) - the appeal of citizens asking for assistance in the implementation embodied in the Constitution and current legislation rights and interests or violation of current legislation or drawbacks in activity of enterprises, institutions, organizations irrespective of forms of ownership, people's deputies of Ukraine, deputies of local councils, officials, as well as a statement of opinion regarding improvement of their activities. Petition - a written request for recognition of a person's relevant status, rights or freedoms, and the like.

The complaint-the appeal with the requirement about renewal of the rights and protection of legitimate interests of the citizens broken by actions(inactivity), decisions of state bodies, local governments, the enterprises, establishments, the organizations, associations of citizens, officials.

Decisions, actions (inaction), which may be appealed, in the field of public administration include the following, which violated rights and legal interests or freedoms of a citizen (group of citizens); created obstacles to the implementation of citizen's rights and legal interests or freedoms; illegal placed on the citizen any duties or illegally prosecuted ${ }^{2}$.

Requirements for applications:

1. Addressed to bodies and organizations, associations of citizens or officials, whose powers include the solution of the issues raised in the appeals.

2. The need to specify the surname, name, patronymic, place of residence of the citizen, statement of the essence of the issue, comments, suggestions, statements or complaints, requests or requirements.

3. Oral requests shall be a citizen and recorded by an official at personal reception and written sent by mail or handed over a citizen to the appropriate authority, the institution, personally or through authorized person.

Failure to comply with these requirements allows the subjects of power not to consider such appeals. In addition, under article 8 of the law of Ukraine "About addresses of citizens" not subject to review: re-treatment one and the same body by the same citizen on the same issue if the first is decided on the merits; complaints against the decision appealed against, if it is submitted to

2 Kuzmenko E. Administrative-procedural law of Ukraine: textbook / O. Kuzmenko, T. A. Gurzhiy; za zag. ed . Kyiv: Atika, 2007. 416 p. 
body or official of higher level after one year from the date of its adoption, but no later than one month from the time of familiarizing the citizen with the decision; appeals of persons recognized by the court as incapable.

An important factor to pay attention to is the period of consideration of applications. According to the requirements of the current legislation, appeals are considered and resolved within a period of not more than one month from the date of their receipt, and those that do not require additional studyimmediately, but not later than fifteen days from the date of their receipt. If within a month it is impossible to resolve the issue violated in the appeal, the head of the relevant body, enterprise, institution, organization or his Deputy shall establish the necessary period for its consideration, as reported to the person who filed the appeal. The General term of the decision of the questions raised in the address cannot exceed 45 days.

It should also be noted that in addition to the above types of appeals of citizens, the Law of Ukraine "on access to public information" allocates another type of appeal-a request for information.

Like other types of citizens ' appeals, the request for information can be individual or collective; it can be submitted orally, in writing or in another form (by mail, Fax, telephone, e-mail).

The request for information is submitted in a free form and must contain: 1) name (name) of the requestor, mailing address or email address, and the number of communications, if any; 2) General description of information or type, name, requisites or content of the document for which the request is made, if the questioner is known; 3) the signature and date, subject of the request in writing ${ }^{3}$.

The law clearly stipulates that a response to a request for information must be provided no later than five working days from the date of receipt of the request. If the request for information relates to information necessary to protect the life or freedom of a person regarding the state of the environment, the quality of food and household items, accidents, catastrophes, natural hazards and other extraordinary events that have occurred or may occur and threaten the safety of citizens, the response must be provided no later than 48 hours from the date of receipt of the request. And if the request concerns the provision of a large amount of information or requires the search of information among a significant amount of data, the term of consideration of the request may be extended to 20 working days with mandatory notification of the requester in writing not later than five working days from the date of receipt of the request.

${ }^{3}$ Scientific and practical commentary of the Code of Ukraine on administrative offences / G. Kalyuzhny, N. Inshin, I. Shopina, etc. - fifth Edition, with amendments and additions as of September 10, 2013 Kyiv: Alerta, 2013. 976 p. 
The request for information may be refused or delayed by the subject of authority. It is possible to refuse to provide information to a person if: - the information Manager does not own and is not obliged according to its competence provided by the legislation to own the information concerning which the request is made; - the information which is requested belongs to the category of information with limited access in accordance with part two of article 6 of this Law; - the person who submitted the request for information has not paid the actual expenses related to copying or printing stipulated by the legislation; - the requirements for the request for information have not been met.

A delay in the satisfaction of a request for information is allowed if the requested information cannot be provided for review within the time limits provided for by this Law in the event of force majeure. The decision on delay is brought to the attention of the requesting in writing with explanation of the order of the appeal of the made decision.

Public administration as a complex phenomenon, which is due to the regulatory influence of public administration in various spheres of public life, can be meaningful only if efficient mechanisms through which the public authorities receive information about its performance in the system of public administration through such means as monitoring, supervision and complaints of citizens, which today are combined as a way to ensure the legality and discipline ${ }^{4}$.

\section{Subjects of proceedings on citizens appeals}

The current legislation, law enforcement practice and theoretical research make it possible to confidently point out the existence of four types of participants in such legal relations, that is, 4 types of subjects of production on citizens ' appeals.

The first type (subjects, applicants) are persons whose applications are considered and on which decisions are made. These are capable citizens of Ukraine, foreigners and stateless persons who are in the territory of the state on legal grounds (unless otherwise provided by international treaties), whose treatment is not subject to article 8 of the Law of Ukraine "on citizens' appeals.

The second type (subjects considering appeals) includes subjects considering appeals and making decisions on them. Such are: public authorities; local governments; enterprises, institutions, organizations; associations of citizens; mass media; prosecutors (according to article 12 of

${ }^{4}$ Kuzmenko O. The Course of the administrative process: proc. benefit. / O. Kuzmenko; NAT. Acad. EXT. cases'. Kyiv: Yurinkom Inter, 2014. 207 p. 
The law of Ukraine "on Prosecutor's office" of October 5, 1991, the Prosecutor considers applications and complaints about violations of the rights of citizens and legal entities, except for complaints, consideration of which is referred to the competence of the court).

A common feature of the administrative-procedural status of these entities is that they cannot refuse to accept and consider appeals. The legislator establishes that appeals duly executed and filed in accordance with the established procedure are subject to mandatory acceptance and consideration.

It is prohibited to refuse to accept or consider a petition with reference to political views, party affiliation, gender, age, religion, nationality, citizen ignorance of the language.

If the issues raised in the appeal received by the authority are not included in the authority's powers, it shall be forwarded to the address within no more than five days. This is reported to the citizen who filed the appeal. If the address does not contain the data necessary for adoption of the proved decision by body or the official, it in the same term returns to the citizen with the corresponding explanations.

The third type (auxiliary subjects) are persons who contribute to the adoption of informed decisions. The law provides for their participation only in the processes of consideration of applications or complaints. The current legislation does not contain a special list of such persons.at the same time, the analysis of the Law of Ukraine "on citizens appeals" shows that such persons are a lawyer, a representative of the labor collective, a representative of an organization performing a human rights function, persons whose fault violations were committed, persons who provide information to the competent authorities during the verification of appeals in accordance with the requirements of articles 15 and 19. The peculiarity of this group of subjects is that the competence of auxiliary subjects is realized at the second stage of production - the stage of consideration of the application or complaint ${ }^{5}$.

The fourth type (patronage subjects) are persons who file an appeal in the interests of the citizen on his authority. The law provides for their participation in the processes of all types of appeals. It should be noted that their participation is regulated in detail in the proceedings on complaints. The peculiarity of this group of subjects is that the competence of patronage subjects is implemented at the 1st stage of production - the stage of filing an appeal. The patronage subjects include: legal representatives of minors and incapacitated persons, labor collectives, law-protective organizations, other persons, authorized persons.

5 Kolpakov V. Administrative-tort process: studies. Benefit./ Kolpakov V., Gordeev V. Kharkiv: Kharkiv legal, 2012. 227 p. 
The General features of the administrative-procedural status of subjects, for example, are: first, the obligation to fulfill a number of requirements. So, in the address the surname, a name, a patronymic, a residence of the citizen has to be specified, the essence of the raised question, remarks, offers, statements or complaints, requests or requirements is stated. Appeals are addressed to public authorities and local self-government, enterprises, institutions, organizations, regardless of ownership, associations of citizens or officials, whose powers include the solution of the issues raised in the appeals. The address issued without observance of these requirements, returns to the applicant with the corresponding explanations not later than in ten days from the date of its receipt; the obligation to bear responsibility for giving of addresses of illegal character. Thus, the law establishes that the submission by a citizen of an appeal containing slander and insults, discredit of state authorities, local self-government bodies, associations of citizens and their officials, heads and other officials of enterprises, institutions and organizations, regardless of ownership, calls for incitement to national, racial, religious hatred and other actions, entails responsibility under the current legislation; allocation in their array of two groups: Heroes of the Soviet Union, Heroes of Socialist Labor, invalids of the great Patriotic war and established that the proposals (comments) of this group of citizens are considered by the first heads of state bodies, local governments, enterprises, institutions and organizations personally; citizens who have benefits established by law and established that their appeals are considered as a priority ${ }^{6}$.

\section{Forms of work on ensuring consideration of citizens ' appeals}

Executive bodies, bodies of local self-government, heads of enterprises, institutions and organizations, regardless of ownership, should be strictly guided by the Constitution of Ukraine, the Law of Ukraine "on citizens appeals" of October 2, 1996 No. 393/96-BP, By presidential decree No. 109/2008 of 7 February 2008 "on priority measures to ensure the implementation and guarantee of the constitutional right to appeal to higherlevel state authorities and local self-government bodies" to ensure the creation of the necessary conditions for the realization of citizens' rights to a written appeal or personal reception and the mandatory receipt of a justified answer to it; to take prompt measures on the merits of the issues raised; to identify and eliminate the causes of complaints and statements of citizens, to decide

\footnotetext{
${ }^{6}$ Scientific and practical commentary of the Code of Ukraine on administrative offences / G. Kalyuzhny, N. Inshin, I. Shopina, etc. - fifth Edition, with amendments and additions as of September 10, 2013 Kyiv: Alerta, 2013. 976 p.
} 
questions of responsibility of officials, through whose fault the violations, the bureaucracy and red tape; to analyze the status of work with citizens and to inform the population; to consider the results of the analysis in practical work; - to actively use the experience of organization of the personal reception directly on the plants at the place of work and residence.

Today, almost all Central and local Executive authorities and local selfgovernment have special structural units to work with citizens' appeals, on the Internet pages of which information on the consideration of citizens' appeals, schedules of personal reception, analytical certificates and the like are submitted. The regional state administrations have established commissions for the consideration of citizens' appeals, commissions for the consideration of repeated appeals, "days of control" of the results of the execution of citizens ' appeals are held, exit receptions, helplines and so on are organized.

Another important mechanism for the implementation of citizens' rights to appeal is the institution of the Verkhovna Rada Commissioner for human rights (Ombudsman), which embodies parliamentary control over the observance of constitutional rights and freedoms of man and citizen. According to article 55 of the Constitution of Ukraine, "everyone has the right to apply for protection of their rights to the Commissioner of the Verkhovna Rada of Ukraine for human rights". According to article 16 of the Law of Ukraine "on the Commissioner of the Verkhovna Rada of Ukraine for human rights", the Commissioner carries out his activities on the basis of information about violations of human and civil rights and freedoms, which he receives from appeals of citizens of Ukraine, foreigners, stateless persons. Such appeals are accepted and considered by the Commissioner in accordance with the Law of Ukraine "on citizens' appeals",

Today, in the system of state bodies, such structures can be conditionally considered law enforcement agencies-the Prosecutor's office and internal Affairs bodies. However, the specificity of their work is that they consider the appeals of citizens in fact, when they are talking about a direct violation of the law. If the law is not violated, the appeal of citizens is not related to their competence. Thus, the issue of creating a separate state body for the purpose of comprehensive objective consideration and analysis of citizens' appeals under the patronage of the President of Ukraine becomes urgent.

It should be noted that the legislator gives special attention to the organizational actions taking place at the first stage of production. In order to provide citizens with an unhindered opportunity to apply, a special form of

\footnotetext{
${ }^{7}$ The code of Ukraine on administrative offences dated 7 December 1984, No. 8073-x URL.: http://zakon4.rada.gov.ua/laws/show/80731-10
} 
receiving proposals, applications and complaints - personal reception of citizens-is established and fixed at the legislative level.

Heads and other officials of public authorities, local governments, enterprises, institutions, organizations, associations of citizens, necessarily carry out such reception. The reception is held regularly on fixed days and hours, at a convenient time for citizens, at their place of work and residence. Reception schedules are brought to the attention of citizens. Heads of the specified structures define the order of reception of citizens.

Consideration of citizens "appeals under the" single window" system is carried out according to the scheme, which can be divided into a number of successive stages:

- advice on the procedure for filing an application and the timing of preparation of the necessary additional documents.

- check of correctness of registration of the application and the package of documents attached to the application;

- registration of the application in the electronic database and issuance to the applicant of an extract from the electronic journal confirming the acceptance of the application;

- formation and direction of inquiries in profile structures for the purpose of obtaining necessary data, coordination and conclusions concerning the decision of the question stated in the statement;

- control over the timing of individual requests and the total period of preparation of the response;

- registration of the prepared response and related documents in the electronic database;

- notification of the applicant;

- issue to the applicant of the answer, necessary documents for the solution of a question or the motivated refusal.

Transformation of the "single window" service multifunctional centers will receive citizens' appeals, provide a full range of public services for issuing documents to individuals, legal entities and individual entrepreneurs, as well as provide other related services to the population. In particular, an integral part of the work of such centers are consulting and reference services, Internet service, legal assistance and the like. Therefore, the creation of an extensive network of special bodies to work with citizens' appeals on a wide range of issues is a positive experience that is used in Ukraine ${ }^{8}$.

In the modern conditions of information society formation, measures within the framework of e-government development are seen as an important

\footnotetext{
${ }^{8}$ Administrative law : textbook / Y. Bytyak, etc. NAT. Yuri. Acad. Ukraine them. Yaroslav The Wise. Kharkiv: Pravo, 2010. 624 p.
} 
direction of increasing the efficiency of work with citizens ' appeals. It has become a common world practice to recognize certain legal force behind appeals transmitted through electronic communication systems.

With the introduction of an automated system of relations "citizen-state" can be counted on to improve the efficiency of public administration and limit corruption. Electronic interaction changes the very nature of government, making it more transparent and controlled by the public, because every citizen will be able to monitor the activities of public authorities and local governments, directly interact with public officials without queues and unnecessary bureaucracy.

Social information, which is in the appeals of citizens, is of great importance for improving the work of the authorities. As you know, the typical meaning of a phenomenon, trends in the development of practice can be recorded with sufficient certainty based on data analysis of a large number of facts that are in the appeals, their generalization. The analysis of such information allows drawing conclusions about the reasons and conditions, prompts ways of elimination of violations, mistakes, shortcomings, to make suggestions for improvement of business, legal response and other

\section{The concept and types of complaints. The ratio of the concepts of "complaint" and "appeal"}

The Constitution of Ukraine establishes the following important ways to protect rights and legitimate interests:

- the administrative and legal method of protection of the rights and freedoms of citizens, enshrined in article 40 of the Constitution of Ukraine, which provides that a citizen has the right to send individual or collective written appeals or personally appeal to state authorities, local self-government bodies and officials and officials of these bodies, who are obliged to consider the appeal and give a reasonable response within the period established by law. One such way is to exercise the right to file a complaint of citizens in administrative proceedings in connection with the violation of their rights and freedoms, including a complaint to the Prosecutor's office, the Commissioner of the Verkhovna Rada of Ukraine for human rights (part 2 of article 55 of the Constitution of Ukraine);

- judicial protection of rights and freedoms (article 55 of the Constitution of Ukraine), which is guaranteed to every citizen and is implemented in accordance with part 2 of article 1 of the Law of Ukraine "on the judicial system" in the forms of civil, economic, administrative, criminal and constitutional proceedings;

Common to all methods is a universal method of protection-appeal to the relevant authorities with a complaint. That is, it can be argued that by 
means of an administrative complaint it is possible to defend and defend, as well as to remove obstacles to the realization of any right or the satisfaction of any interest that does not contradict the General principles and current norms of law.

By means of the complaint in Ukraine it is possible to protect the rights and interests-public, special and office. By the way, not only those that are directly violated or infringed, but also those concerning which persons have doubts about their "non-violation" by public authorities, that is, a complaint filed in connection with possible violations.

This provision is certainly a positive element of the legal system of a democratic state and requires fixing in the legislation, especially in relation to an administrative complaint ${ }^{9}$.

Again, based on the meaning of legal institutions, it can be stated that the Institute of administrative complaints can be used by subjects in both positive management relations and in relations that are associated with coercive influence, including those associated with the use of punitive measures.

In the modern period of development of the legal system of Ukraine, the right to complain finally received legislative form.

The possibility of protecting the rights of citizens by filing a complaint is established by a significant number of acts, according to which a wide range of relevant officials are obliged to consider administrative complaints. The addressees of the complaint may be:

- President of Ukraine;

- Commissioner of the Riding Council for human rights;

- Executive authorities (including the highest) and their officials;

- bodies of Prosecutor's office of Ukraine;

- courts and other subjects authorized to consider complaints.

That is, it can be concluded that all actions for the final legal registration of an administrative complaint at the level of a real and effective way to protect the rights and interests of citizens in Ukraine have been formed.

"To serve as a means of protecting the rights and legitimate interests of citizens is one of the main functions ... right to appeal". That is why the right to a complaint should be considered from the position of legal guarantees, as a legal guarantee of the realization of human rights-it is important that not only citizens of Ukraine, but also foreign citizens, stateless persons, as well as all forms of their associations located on the territory of Ukraine ${ }^{10}$.

\footnotetext{
${ }^{9}$ Perepelyuk V. Administrative process. General part: Textbook / V. Perepelyuk. Kyiv: center of educational literature, 2004. 367 p.

10 Administrative justice. Administrative proceedings: studies.benefit. / T. Kolomoets, G. Gulevskaya, R. Sinelnik, I. Skvirsky. Kiev: Istina, 2007. 152 p.
} 
Thus, a complaint is an appeal of the subject of administrative and legal relations in the public administration (court) and its officials (judges), who are authorized to solve the administrative and legal dispute (within the established competence), in order to protect the subjective rights and interests that are violated or may be violated by the decisions, actions or inaction of the power subject of administrative and legal relations.

Types of complaints:

In the form of receipt: by mail; at a personal reception; through an authorized person; through authorities, through the media; from other bodies, institutions, organizations.

Based on income: primary; repeated; doublet; repeated; mass.

For the article the authors of references: men's; women's.

On the subject of: individual; collective; anonymous.

By type: telegram; letter; oral.

By category the authors of references: a war veteran; children of war; the invalid of the great Patriotic war; disabled veteran; combatant; a veteran of labor; group disability; group II disability; a disabled person of group III; a disabled child; single mother; a mother; a large family; a victim of the Chernobyl disaster; the participant of liquidation of consequences of Chernobyl accident; the Hero of Ukraine, Hero of the Soviet Union; Hero of Socialist Labor; child; other categories.

According to the social status of the authors of appeals: pensioner; worker; peasant; public sector employee; civil servant; soldier; entrepreneur; unemployed; student, student; Minister of a religious organization; a person deprived of liberty; a person whose freedom is limited; others.

By results of consideration: it is solved positively; it is refused satisfaction; explanations are given.

Treatment, returned to the author under articles and of the law of Ukraine "About addresses of citizens": the Appeal is forwarded to the facilities in accordance with article of the law of Ukraine "On appeals of citizens"; an Appeal is not subject to review in accordance with the articles of the law of Ukraine "On appeals of citizens".

The form of the complaint can be classified into administrative complaint; statement of claim.

The complaint and the administrative claim are specific forms of the address of physical and legal entities through which they pronounce own discontent with actions or inaction, decisions of public governing bodies and their officials. the Administrative claim (statement of claim) is in many respects similar to the administrative complaint, but similarity is external. In the administrative complaint, the claim element is contained in an underdeveloped form. Filing an administrative complaint does not make a 
citizen a party, does not stipulate his personal participation in the administrative process. "The Complainant," as rightly pointed out. Zagryatskov - - has no signs of the party in disputes about the right, he remains the person who asks". This position in legal relations takes the character of a vertical. The citizen waits for the decision on the complaint "from above". At the same time, filing a lawsuit in an administrative court leads to the emergence of original management relations: they are law enforcement and at the same time horizontal, in which subjects (citizenplaintiff and official-defendant) confront each other as equal parties. The plaintiff does not wait for "mercy" from above, but receives the decision of an independent and objective body. A natural or legal person dissatisfied with the actions (inaction) or decisions of the public administration takes a personal part in the process as a party. The right of administrative action is the right of a citizen to judicial protection in cases of violation of his subjective right in the field of public administration.

At the same time, it is necessary to dwell on the theoretical terms "complaint" and "appeal", as in the theoretical literature in practice, these terms are often used as synonymous ${ }^{11}$.

For the first time misunderstanding concerning these terms was brought by the legislator who in the Constitution of the USSR of 1977 used a turn not "the right to the complaint", and "the right to the appeal".

The concept of the complaint we have defined above, at the same time, the "appeal" is the law consistent procedure for submitting a complaint to public authority (court) and its officials (judges) who are empowered to resolve administrative-law dispute (within established authority), in order to protect subjective rights and interests that are violated or may be violating the decisions, actions or inaction of the power of the subject of administrative legal relations.

That is, an appeal is an activity to implement a public complaint. It should be noted that the order of implementation of the complaint depends on what body (official) the person addresses. Accordingly, the appeal of a person to a public management body is regulated by the legislation on citizens ' appeals, other normative-legal acts of the branch direction and lay the procedural basis for the consideration of positive cases of a managerial and service nature.

The appeal of subjects to administrative court with the statement of claim accepts the maintenance of administrative-procedural consideration of the address according to requirements of judicial process.

11 Administrative law: textbook / NU "YUAU im. Yaroslav the Wise"; for zag. ed: Y. Bytyak, V. Garashchuk, V. Zui. - 2nd view., rewritten. and extra. Kharkiv: Pravo, 2013. $656 \mathrm{p}$. 
Thus, consideration and resolution of complaints of individuals and legal entities is carried out by the public administration in a certain manner regulated by legal norms, through separate administrative and procedural proceedings.

\section{Structure of administrative proceedings on the complaint of individuals and legal entities}

Administrative and procedural proceedings on complaints of citizens in accordance belong to the group of procedural proceedings, as has the conditional name "on appeals of citizens".

In administrative and procedural proceedings on the complaint of a person, the following stages can be distinguished:

1) initiation of proceedings on the complaint;

2) checking the content of the complaint;

3) consideration and decision - making on the complaint;

4) appeal of the decision taken on the complaint to a higher authority (court). (Optional stage);

5) implementation of the decision on the complaint.

Let us consider in detail the content of these stages.

The law of Ukraine "About addresses of citizens" (article 16) defines the General rule, according to which, the complaint against actions or decisions of a public administration, enterprises, institutions, organizations, associations of citizens, mass media, officials is served in subordination order to higher body or official that does not deprive the citizen of the right to appeal to court in accordance with applicable law, and in the absence of such body or disagreement of the citizen with the decision on the appeal decision directly to the court.

The procedure of administrative appeal, in which the addressee of complaints is the Executive authority of the highest level (official), follows from the principles of functioning of the system of Executive authorities, namely-subordination, which implies the subordination of lower - level body's hierarchically higher bodies. Subordination and subordination, as elements of subordination, of the Executive authority of a lower level to a higher authority create for the latter an opportunity to influence the functioning of the subordinate authority, in particular, to change or cancel its decisions or oblige it to commit or terminate certain actions.

However, analyzing the content of the norm establishing a rule that the subject of the complaint stands Higher in the chain of command, the public authority (official) regarding the body (official) that made the decision, committed an act or made an omission, should indicate that it has the character rather of the norm-the principle than the norm-imperative, 
establishing a single possible behavior. According to the principle of action, such a rule is provided in art. 55 of the Constitution of Ukraine - "human and civil rights and freedoms are protected by the court", which does not exclude the possibility of the protection of human and civil rights and other authorized bodies. That is why the subject of the complaint may be not only higher as subordination body (official), the body (official) decisions, actions or omissions which are appealed, if the subject of application that addresses their requirements. Often, the appeal to the body (official), the decision, actions or inaction of which are appealed, allows to ensure, firstly, a qualified examination of the complaint, since the Executive authority is already familiar with the case and, secondly, helps to remove the conflict between the authority and the person, which is important for the formation of positive relations between these subjects.

The complaint may be filed orally or in writing. Oral complaints are stated by the citizen and fixed by the official on personal reception of citizens. The duty for heads and other officials of Executive authorities to carry out personal reception of citizens is fixed in Art. 22 of the Law of Ukraine "About addresses of citizens".

Any documents and other materials relating to the issues raised in the appeal may be attached to the Complainant's written application.

Anonymous appeal is registered, but is not subject to consideration and filed in the case of the nomenclature of cases. The decision on recognition of the address anonymous and leaving it without consideration is made by the Chairman of public body on representation of the head of Department of organizational and documentary maintenance or other official of public body authorized on record keeping on addresses of citizens.

All citizens' complaints received by public authorities must be accepted, previously considered and centrally registered on the day of their receipt in the manner prescribed By the instruction on record-keeping on citizens' appeals in state and local authorities, associations of citizens, enterprises, institutions, organizations, regardless of ownership, in the media, approved by the resolution of the Cabinet of Ministers of Ukraine of 14 April 1997 No. 348.

Thus, all complaints received should be accepted and centrally registered on the day of their receipt on registration and control cards suitable for processing by personal computers, or in journals. Envelopes (clippings from them) are stored together with the complaint. Registration of personal reception of citizens is conducted on cards, in magazines or by means of electronic computer equipment.

The journal form of registration of offers, applications and complaints and the account of personal reception of citizens is allowed in the organizations 
with annual volume of receipt to 600 offers, applications and complaints and the same number of addresses of citizens on personal reception.

Written complaints filed at a personal reception are also subject to centralized registration on registration and control cards suitable for processing by personal computers, or in journals ${ }^{12}$.

Automated registration of complaints and registration of personal reception of citizens are carried out from the registration and control forms by entering into a personal computer the following elements: date of receipt of the appeal; surname, name, patronymic, category (social status) of the applicant; where the appeal was received, date, index, control; issues raised-summary, indices; content and date of resolution, surname of the author, performer, deadline; date of dispatch, index, content of the document, decisions taken, date of removal from control; case number on the nomenclature.

An official authorized to conduct record keeping on citizens' appeals carries out preliminary consideration of citizens' complaints in public administration bodies.

Preliminary consideration includes verification of correctness of registration, acquaintance with the contents, and determination of the order of further work on the complaint of the citizen (citizens).

The applicant (s) with the date must sign the written complaint.

A complaint filed without complying with these requirements shall be registered and returned to the Complainant with the relevant explanations no later than five days from the date of its receipt. A copy of such complaint and a copy of the letter of explanation, which returned the complaint to the applicant, remains in the body to which the applicant applied. The decision to return the appeal to the Complainant is made by the head of the authority ${ }^{13}$.

Repeated complaints by the same body from the same citizen on the same issue are not considered, if the first is resolved in fact, as well as complaints that are filed in violation of the terms provided for in article 17 of the Law of Ukraine "on citizens "appeals" and complaints of persons recognized by the court as incapable.

At the request of a citizen who filed a complaint with the organization, on the first sheet of a copy of the appeal, a stamp is stamped indicating the name of the organization, the date of receipt and the incoming number of the appeal. Such copy is returned to the citizen.

${ }^{12}$ Scientific and practical commentary of the Code of Ukraine on administrative offences / G. Kalyuzhny, N. Inshin, I. Shopina, etc. - fifth Edition, with amendments and additions as of September 10, 2013 Kyiv: Alerta, 2013. 976 p.

${ }^{13}$ Administrative and legal protection of citizens ' rights: studies.-method. possib. / [Col. K. Afanasiev et al.]; Lugano. state University EXT. cases to them. E. Didorenko. Lugansk : RIO LGUSD them. E. Didorenko, 2011. 279 p. 
Complaints containing issues that are not within the competence of a public body shall be forwarded to the relevant body competent for consideration within five days after its registration, and the Complainant shall be notified thereof at the same time, with an explanation of the grounds for submitting the complaint. The decision to forward the complaint by affiliation is made by the head of the public body or his Deputy in accordance with the distribution of functional responsibilities. The copy of the complaint of the citizen remains in business of public body, which forwarded the original of the address on accessory to the corresponding body.

The complaint is sent by mail or transmitted to the appropriate body by a citizen personally or through an authorized representative, if his powers are issued in accordance with the current legislation.

In addition, according to the content of the Law of Ukraine "on electronic documents and electronic document management" of 22.05.2003, the complaint can be sent (filed) in electronic form with mandatory compliance with the requirements for its details and requirements for the submission of electronic documents.

According to article 5 of the Law of Ukraine "on electronic documents and electronic document circulation", an electronic document is a document in which information is recorded in the form of electronic data, including mandatory document details. This Law (article 8) provides that the legal force of an electronic document cannot be rejected solely because it has an electronic form. The author or the intermediary in electronic form by means of information, telecommunication, and information and telecommunication systems or by sending electronic carriers on which this document is recorded carries out Sending and transmission of electronic documents.

Citizens have the right to file complaints with the public administration or its officials in Ukrainian or another language acceptable to the parties. A citizen may file a complaint in person or through another person authorized to do so. Complaints may be filed in the interests of citizens by a labor collective, an organization engaged in human rights activities, or another person, if their powers are issued in accordance with the procedure established by law.

The complaint shall be accompanied by the decisions available to the citizen or copies of the decisions that were taken on his appeal earlier, as well as other documents necessary for the consideration of the complaint, which after its consideration shall be returned to the citizen ${ }^{14}$.

14 Administrative law of Ukraine. Vol. 1: General administrative law: textbook: in 2 volumes / Galunko V. et al. Kherson: PJSC "Kherson city printing house", 2017.320 p. 
The prohibition of refusal to accept and consider complaints with reference to political views, party affiliation, gender, age, ignorance of the language of the appeal. At the same time, it should be noted that the legislation still establishes some restrictions on the age of persons who have the right to file complaints independently. For example, in the interests of minors, their legal representatives file complaints. The same procedure is provided for filing complaints and in the interests of incapacitated persons.

Complaints duly executed and filed in accordance with the established procedure are subject to mandatory acceptance and consideration. Each complaint must be made one of these decisions:

- take to production;

- submit the decision to a subordinate body or institution. At the same time, it is forbidden to send citizens ' complaints for consideration to those bodies or officials whose decisions, actions or inactivity are being appealed;

- transfer by affiliation to another office, if the issues raised in the complaint are not within the competence of the body that received the complaint, which is simultaneously reported to the subject of the appeal;

- to leave without consideration, in the presence of the bases defined by the law.

A written complaint is logged, it is exposed retrace control card, which is the main accounting document written request of a citizen, which gradually, as the consideration of the application is filled in such information, in particular:

a) registration index and date of receipt of the complaint;

b) surname, name and patronymic of the citizen;

c) address of the citizen;

d) the name of the public authority, other bodies, institutions, organizations, mass media, the surname and initials of the authorized person complaining in the interests of the applicant, the outgoing number and date of the letter to which the complaint was sent;

e) summary of the complaint;

f) resolution of the head of the public body;

f) date and grounds for refusal to consider the complaint or termination of consideration, position, surname and initials of the official who made this decision;

g) data on bringing the complaint to the executors and moving the complaint in accordance with the subordination;

h) the outgoing number and date of the letter by which the complaint, the decision of which is not within the competence of the public authority, was sent for consideration to another body; 
i) information about the requests sent during the complaint (where or to whom they were sent, dates and outgoing numbers of requests, registration numbers and dates of responses received);

j) results of consideration of the complaint, date and outgoing number of the answer to the citizen;

k) the case number in which the complaint is stored;

1) data on the receipt of repeated and duplicate complaints.

The head of a public body is obliged to find out the reasons for the receipt of a repeated complaint of a citizen. If it is caused by violation of the established order of consideration, the officials who have allowed violation of the rights of the citizen bear responsibility according to their job descriptions and the legislation of Ukraine.

Written complaints of citizens addressed to the head of a public body shall be subject to mandatory consideration by the head of a public body (an official performing his duties) or Deputy heads of a public body in accordance with their powers in order to determine whether the issues raised in these complaints fall within the competence of public bodies;

Appeals of women who are awarded the honorary title of Ukraine "Mother-heroine", Heroes of Ukraine, Heroes of the Soviet Union, Heroes of Socialist Labor, invalids of the great Patriotic war are taken under personal control and are considered by the heads of public bodies personally.

Citizens' complaints are sent to the head of the public body or his deputies for consideration on the day of their receipt.

Repeated and duplicate complaints received after the processing of the primary complaint are submitted for consideration together with the materials of the primary complaint ${ }^{15}$.

It is prohibited to entrust the consideration of a citizen's complaint to an official whose decision, action or inaction is being appealed.

Decisions taken on complaints must be motivated and based on the norms of the legislation and brought to the attention of the applicant. The official, having recognized the complaint subject to satisfaction, is obliged to provide timely and correct execution of the made decision, and in case of recognition of a question of the complaint reasonable - to take measures to restoration of the violated rights of citizens.

When considering complaints, special attention is paid to solving problems faced by war and Labor veterans, disabled people, citizens affected by the Chernobyl disaster, large families, single mothers and other citizens in need of social protection and support.

${ }^{15}$ Administrative procedural law of Ukraine: Textbook. / Edited by O. V. Kuzmenko. Kyiv: Atika, 2007. 416 p. 
It should be noted that at any stage of consideration of the complaint, the public body (official) must ensure the subject of the appeal and other participants of administrative proceedings the implementation of their procedural rights. According to the Law of Ukraine "on citizens' appeals" the subject of the appeal has the following rights:

- personally present the arguments to the person who checked the complaint, and participate in the verification of the complaint;

- to get acquainted with materials of check;

- submit additional materials or insist on their request by the body that considers the complaint;

- to be present at consideration of the complaint;

- to use the services of a lawyer or a representative of a labor collective, an organization that performs a human rights function, having issued this authority in accordance with the procedure established by law;

- receive a written response on the outcome of the complaint;

- to Express orally or in writing the requirement about observance of secrecy of consideration of the complaint;

- claim damages if they were the result of violations of the established procedure for consideration of complaints.

The specified volume of procedural rights of the subject of the address as a whole is sufficient for realization of its legitimate interests in the process of consideration of complaints. At the same time, in our opinion, the subject of the appeal should have the right to demand compensation not only for those losses that resulted from violations of the established procedure for consideration of complaints, but also those that were caused due to nonexecution or improper execution of decisions on the complaint.

In turn on the subject of the decision of the case the following duties are assigned:

- objectively, comprehensively and on time to check complaints;

- in case of adoption of the decision on restriction of access of the citizen to the relevant information at consideration of the complaint to make about it the reasoned resolution;

- at the request of a citizen to invite him to a meeting of the relevant body considering his complaint;

- to cancel or change the appealed decisions in the cases provided by the legislation of Ukraine if they do not meet the law or other normative acts, immediately to take measures to the termination of illegal actions, to reveal, eliminate the reasons and conditions promoting offenses;

- to ensure the restoration of violated rights, the real implementation of the decisions taken in connection with the complaint;

- to inform in writing to the citizen about results of check of the complaint and an essence of the made decision; 
- to take measures regarding the compensation in the manner prescribed by law material losses if they were caused to a citizen as a result of infringement of his rights or legal interests, decide issues on responsibility of persons, through whose fault the violation has taken place, and at the request of the citizen not later than within a month to bring the decision to the attention of the local authority, labor collective or Union of citizens at citizen's place of residence;

- in case of recognition of the statement or the complaint unreasonable, to explain an order of the appeal of the decision made on it;

- to prevent unjustified transfer of complaints to other bodies;

- to organize and check the status of consideration of citizens' complaints, to take measures to eliminate the causes that give rise to them, to systematically analyze and inform the population about the progress of this work.

This list of duties of the subject of the resolution of the case should be supplemented by the obligation to familiarize the participants of administrative proceedings with their procedural rights and obligations, which would be an additional guarantee of their implementation in this production ${ }^{16}$.

At the same time, it is necessary to emphasize an important feature that characterizes the content of the complaint proceedings. It is manifested in the fact that the specified production is characterized by clearly defined deadlines.

So, the term of consideration of the complaint of citizens is calculated from the day following the day of registration of the complaint in public body, on the day of registration to the Complainant of the answer to his complaint. If the last day of the term of consideration of the complaint falls on a nonworking day, the last day of the term is the first working day after it.

Complaints are considered and decisions are made on them within a period of not more than one month from the date of their receipt, taking into account weekends, holidays and non-working days, and those that do not require additional study and verification on them - immediately, but not later than 15 days from the date of their registration.

If it is impossible to resolve the issues raised in the complaint within a month, the head of the relevant public body or his Deputy shall set the time required for consideration of the appeal, as reported to the person who filed it. At the same time, the total term for resolving the issues raised in the appeal may not exceed 45 days. The specified terms are settled In. 17 of the Law of Ukraine "on citizens' appeals", which notes that a complaint against a decision, appealed, may be filed with a body or an official of the highest level within one year from the date of its adoption, but not later than one month

${ }^{16}$ Administrative procedural law of Ukraine: Textbook. / Edited by O. V. Kuzmenko. Kyiv: Atika, 2007. 416 p. 
from the time of familiarization of the citizen with the decision. Complaints filed in violation of the deadline are not considered.

At the same time it should be noted that the term of the administrative appeal provided by Art. 17 of the Law of Ukraine "on citizens' appeals" contradicts Art. 289 of the Code of Ukraine on administrative offenses, where it is determined that the complaint against the decision in the case of an administrative offense can be filed within ten days from the date

At the same time, certain provisions establish the possibility of increasing the time for consideration of complaints. So, for example, in the order of consideration of appeals and personal reception of citizens in the State customs service of Ukraine, other customs authorities, specialized customs institutions and organizations it is specified that in case of impossibility owing to objective reasons of performance in due time of the instruction of the head (Deputy head) of customs body on consideration of the address this term can be extended by the head (Deputy head) of customs body which provided the instruction. Thus the head of division-executor in advance, but not later than five days before the end of term, reports on it to the head (the Deputy head, charged to consider addresses) of customs authority and raises a question of extension of term of execution of the order within the terms established by the legislation on addresses of citizens. In this case, the applicant no later than one day before the expiration of the previously defined period of consideration of the appeal is sent a written notice of the extension of the period of consideration of the appeal with reasoned explanations.

At the same time, in the Instruction on the order of consideration of addresses and personal reception of citizens in bodies of the state tax service it is specified that the complaint against the decision appealed, can be submitted to body of The state tax service of the highest level within one year from the moment of its acceptance, but not later than one month from the time of acquaintance of the citizen with the made decision. Complaints filed in violation of the specified period, the State tax authorities are not considered.

To resolve these differences, it is necessary either to establish a single deadline for filing complaints, or to stipulate in the Law of Ukraine "on citizens' appeals" the possibility of establishing other deadlines for appeal in legislative acts.

Complaints filed in violation of the term specified in the law are not considered. At the same time, separate normative legal acts establish that if the deadline for filing complaints is missed for a good reason, the body or official considering the complaint can restore it.

For example, in the Instruction on the procedure for consideration of appeals and personal reception of citizens in the state tax service, it is indicated that the State tax service body considering the complaint can restore 
the time missed for a good reason. That is, the specified norm violates the rule of conduct established in art. . 8 of the Law of Ukraine "on citizens" appeals". At the same time, from the point of view of democratic principles of formation of the legislation it is impossible to forbid consideration of complaints, which term of submission, is missed for the objective reasons. Therefore, in our opinion, the specified article demands editing in the following: "the address of citizens which deadline is passed for the objective reasons can be renewed by the body considering the address".

It should be noted that when considering a complaint, it is prohibited to disclose information about citizens and the content of the complaint to persons not involved in the implementation of the complaint.

The answer on results of consideration of the complaint without fail is provided by that public body which received it and which competence includes the decision of the questions raised in the complaint, under the signature of heads or persons to whom the right to make the signature is provided by the head of public body.

The decision on refusal in satisfaction of the requirements or requests stated in the complaint is brought to the attention of the citizen in writing with reference to the current legislation and statement of motives of refusal, and with explanation of the order of the appeal of the made decision. The measures taken by the public authority to verify the complaint are indicated.

The complaint is considered fully processed if considered all its questions, made an informed decision and taken the necessary measures to address the issues raised and the applicants notified of the outcome of the complaint and the decision.

It should be noted that the legislation establishes the obligation to generalize the content of complaints, critical comments that they contain in order to timely identify the causes that lead to violations of the rights and interests of citizens, study public opinion, improve the work of public administration. Special attention is paid to the elimination of the causes that cause repeated and collective complaints, as well as forcing citizens to contact the public authorities, the media on issues that can and should be considered by the public administration on the spot. According to the results of the analysis, an analytical report with specific proposals for further improvement of the organization of work with citizens ' appeals is necessarily drawn up.

At the same time it should be noted that in modern conditions of information society formation an important direction to enhance the efficiency of work with citizens 'complaints are measures in the framework of e-government development. A common world practice has become the recognition of appeals (including complaints) transmitted through electronic communication systems, a certain legal force. 
Thus, in the United States, government officials are required to receive and process citizens' letters sent to the authorities by e-mail, and to give official answers to them. The Scottish Parliament has an electronic appeals system (e-petitioning), which allows each citizen to promptly propose any issue for consideration. All requests are considered and a response is prepared for each. The UK Parliament introduces a similar system. In 2008, this way more than $7 \%$ of the citizens of the state addressed to the Parliament with their complaints and proposals. In 2002 in the Italian city of Bologna, a special decree was issued, which instructed the city Executive authorities to actively use the advice of citizens expressed at the municipal Internet forum, to answer questions, as well as based on messages to highlight and analyze pressing problems. A slightly different scheme was used in the city of Modena, where instead of a forum; a system of the so-called electronic newssheet (newsletter) was created. Leaving your personal data, the citizen was able to regularly obtain on their own e-mail address information about the plans of the city Council, ask questions via email and receive answers in the statutory period, to complain of actions of officials and get an answer on the merits. In addition, a number of online counselling centers have been set up and online surveys have been conducted. Similar experiments were also conducted at the local government level in other Italian cities ${ }^{17}$.

With the introduction of an automated system of relations "citizen-state" can be counted on to improve the efficiency of public administration and limit corruption. Electronic communication can change the very nature of government, make it more transparent and controlled by the public, because every citizen will be able to monitor the activities of the public administration, directly interact with government officials without queues and unnecessary bureaucracy.

Therefore, the development of such a form of work with citizens 'complaints as electronic complaints via the Internet and e-mail should be considered not as an auxiliary, but as one of the main directions in the field of improving the work with citizens' complaints and overcoming corruption [3].

\section{Legal liability for violation of the legislation on citizens' appeals}

The structure of the system of work with citizens 'appeals is incomplete without considering the issue of legal liability for violation of the legislation on citizens' appeals.

As a General rule, prosecution for violation of the legislation on citizens' appeals takes place in accordance with the current legislation on

\footnotetext{
${ }^{17}$ Demsky E. Administrative procedural law of Ukraine: studies. no. / E. F. Demsky. Kyiv: Yurinkom Inter, 2008. 496 p.
} 
administrative, criminal and civil liability. That is, it will depend on the features of the offense, the importance of the issue, the complexity and severity of the act.

Legal liability for violation of the legislation on citizens' appeals can be divided into:

1) legal liability of officials;

2) legal responsibility of citizens.

Article 24 of the Law of Ukraine "on citizens' appeals" provides for civil, administrative or criminal liability for persons guilty of violating the legislation on citizens' appeals, provided for by the legislation of Ukraine.

Citizens have the right to recovery of the material (monetary) losses caused to them by illegal actions of the officials who took part in consideration of addresses of citizens or directly solved business. Such cases are decided in court. Note that you do not need to "fear" the trial; remember that according to the Constitution of Ukraine, the court is the main guarantor of the protection of citizens' rights. Article 55 of the Constitution of Ukraine establishes the right of everyone to appeal against decisions, actions or inactivity of public authorities, local authorities, officials and officials.

In the case of satisfaction of complaint, body or official person who has accepted an illegal decision concerning application of the citizen, reimburse him for the damage associated with the submission and consideration of complaint, reasonable expenses incurred in connection with the departure for the consideration of the complaint at the request of the relevant body, and lost during this time earnings. Disputes on recovery of expenses are considered in court.

A citizen at his request and in accordance with the procedure established by the current legislation may be compensated for moral damages caused by unlawful actions or decisions of the body or official when considering a complaint. The amount of compensation for moral (non-property) losses in monetary terms is determined by the court (article 25 of the Law of Ukraine “on citizens' appeals").

Material losses may include both costs associated with travel for consideration of the complaint by the relevant authority, and lost earnings, lost income during this time. Non-pecuniary damage can be more substantial for monetary as it concerns physical and mental health. The amount of compensation for moral damage in monetary terms is determined by the court. Moral harm is recognized that it led to moral suffering, loss of normal life relationships, the cost of additional efforts to organize their lives. The characteristics of moral harm are contained in the resolution of the Plenum of the Supreme Court No. 4 of 31 March 1995 "on judicial practice in cases of 
compensation for moral (non-property) harm". In particular, moral damage includes loss or humiliation of a person's business reputation.

The law of Ukraine" on citizens' appeals" also provides for the responsibility of citizens for filing appeals of an illegal nature. Thus, article 26 of this law States that the submission by a citizen of an appeal containing slander and insults, discredit of public authorities, local self-government bodies, associations of citizens and their officials, heads and other officials of enterprises, institutions and organizations, regardless of ownership, calls for incitement to national, racial, religious hatred and other actions, entail responsibility under the current legislation.

The legislation also provides for property liability of citizens. In particular, expenses incurred by a public authority, local self-government, institution, organization, regardless of ownership, associations of citizens, enterprise, mass media in connection with the verification of appeals containing false information may be recovered from citizens by a court decision (article 11 of the Law of Ukraine “on citizens' appeals).

It should be noted that the legislation does not directly provide for liability for specific offenses in the process of consideration of appeals, and the articles of the Law of Ukraine "on citizens' appeals" do not define sanctions for relevant violations, which, undoubtedly, is a serious drawback of the current legislation.

\section{CONCLUSIONS}

Thus, the Law of Ukraine "About addresses of citizens" (article 16) defines the General rule, according to which, the complaint against actions or decisions of a public administration, enterprises, institutions, organizations, associations of citizens, mass media, officials is served in subordination order to higher body or official that does not deprive the citizen of the right to appeal to court in accordance with applicable law, and in the absence of such body or disagreement of the citizen with the decision on the appeal decision directly to the court.

The procedure of administrative appeal, in which the addressee of complaints is the Executive authority of the highest level (official), follows from the principles of functioning of the system of Executive authorities, namely-subordination, which implies the subordination of lower - level bodies' hierarchically higher bodies. Subordination and subordination, as elements of subordination, of the Executive authority of a lower level to a higher authority create for the latter an opportunity to influence the functioning of the subordinate authority, in particular, to change or cancel its decisions or oblige it to commit or terminate certain actions. 


\section{SUMMARY}

Constitutional provision of citizens to appeal. The concept of production on appeals of citizens. Place of production on citizens' appeals in the administrative process. The legal basis of the proceedings on the treatment of citizens. Term of consideration of citizens' appeals. Forms and types of appeals of citizens. Requirements for treatment. Appeals that are not subject to consideration and decision. Stages of production on appeals of citizens. Responsibility for violation of the legislation on citizens' appeals.

The concept and types of administrative appeal. Appeal in administrative procedure. Deadline for filing a complaint. Decisions, actions (inaction) that can be appealed. Judicial appeal of actions and decisions of subjects of power. Administrative justice as a form of judicial protection of human and civil rights and freedoms in the sphere of Executive power. Functions and powers of administrative courts. Types of proceedings in administrative courts. Subject of appeal in administrative courts. Characteristics and types of proceedings in cases of administrative appeal.

\section{REFERENCES}

1. Administrative justice. Administrative proceedings: studies.benefit. / T. Kolomoets, G. Gulevskaya, R. Sinelnik, I. Skvirsky. Kiev: Istina, 2007. $152 \mathrm{p}$.

2. Administrative law: textbook / Y. Bytyak, etc. NAT. Yuri. Acad. Ukraine them. Yaroslav the Wise. Kharkiv: Pravo, 2010. 624 p.

3. Administrative law of Ukraine. Vol. 1: General administrative law: textbook: in 2 volumes / Galunko V. et al. Kherson: PJSC "Kherson city printing house", 2017. $320 \mathrm{p}$.

4. Administrative procedural (judicial) law of Ukraine: Studies. / Odessa national law Academy / S. Kivalov (ed.). Odessa: Legal literature, 2007. 312 p.

5. Administrative and legal protection of citizens' rights: studies.-method. possib. / [Col. K. Afanasiev et al.]; Lugano. State University EXT. cases to them. E. Didorenko. Lugansk: RIO LGUSD them. E. Didorenko, 2011. 279 p.

6. Administrative procedural law of Ukraine: Textbook. / Edited by O. V. Kuzmenko. Kyiv: Atika, 2007. 416 p.

7. Bandurka O. Administrative process: Textbook for the University / O. Bandurka, M. Tishchenko. Kiev: Litera LTD, 2002. 286 p.

8. Demsky E. Administrative procedural law of Ukraine: studies. no. / E. F. Demsky. Kyiv: Yurinkom Inter, 2008. 496 p.

9. Kolpakov V. Administrative responsibility (administrative-tort law): Textbook / V. Kolpakov. Kyiv: Yurinkom Inter, 2008. 256 p. 
10. Kolpakov V. Administrative-tort process: studies. Benefit. I Kolpakov V., Gordeev V. Kharkiv: Kharkiv legal, 2012. 227 p.

11. ComSoc A. Administrative process of Ukraine: textbook/ ComSoc A. Bevzenko, R. Miller. Kiev: A Precedent, 2007. 531 p.

12. Kuzmenko E. Administrative-procedural law of Ukraine: textbook / O. Kuzmenko, T. Gurzhiy; za zag. ed . Kyiv: Atika, 2007. 416 p.

13. Kuzmenko O. Administrative justice in Ukraine: textbook / O. Kuzmenko. Kyiv: Atika, 2007. 156 p.

14. Kuzmenko O. The Course of the administrative process: proc. benefit. / O. Kuzmenko; NAT. Acad. EXT. cases'. Kyiv: Yurinkom Inter, 2014. 207 p.

15. Perepelyuk V. Administrative process. General part: Textbook / V. Perepelyuk. Kyiv: center of educational literature, 2004. 367 p.

16. Administrative law: textbook / NU "YUAU im. Yaroslav the Wise"; for zag. ed: Y. Bytyak, V. Garashchuk, V. Zui. 2nd view., rewritten. and extra. Kharkiv: Pravo, 2013. 656 p.

17. Administrative procedural law: studies. no. / Dnepropetr. state University EXT. del; for zag. ed. Kharkiv: Pravo, 2013. $352 \mathrm{~s}$.

18. The code of Ukraine on administrative offences dated 7 December 1984, No. 8073-x URL: http://zakon4.rada.gov.ua/laws/show/80731-10

19. Course of administrative law of Ukraine: Textbook / V. Kolpakov, O. Kuzmenko, I. Pastukh -2nd ed., redistribution. and extra. Kyiv: Yurinkom Inter, 2013. $872 \mathrm{p}$.

20. Scientific and practical commentary of the Code of Ukraine on administrative offences / G. Kalyuzhny, N. Inshin, I. Shopina, etc. - fifth Edition, with amendments and additions as of September 10, 2013 Kyiv: Alerta, 2013. 976 p.

21. Kuzmenko O. Course of administrative responsibility. Textbook./ed. Kuzmenko O. Kiev: Yurinkom inter, 2015. 568 p.

\section{Information about the author: Predmestnikov O. G., Doctor of Law, Professor,} First Deputy Head of the Main Territorial, Department of Justice in the Kherson Region 42/14, Potiomkinska str., Kherson, 73040, Ukraine 


\section{ORGANIZATION OF ACTIVITIES OF PATROL POLICE, SECURITY POLICE AND SPECIAL PURPOSE POLICE}

\section{Rachinska I. M.}

\section{INTRODUCTION}

This work highlights the main issues relating to the organization and activities of the newly established Institute-patrol police, namely: legal regulation and principles of the patrol police of Ukraine; tasks and functions of the patrol police; organization of the patrol police of Ukraine; rights and duties of the inspector of the patrol police of Ukraine; administrative and jurisdictional activities of the inspector of the patrol police of Ukraine regarding the consideration of cases of administrative offenses. As well as other issues associated with: the legal regulation of police activities for the protection; the main tasks and functions of the special purpose police; the rights and duties of the special purpose police.

\section{Legal regulation and principles of the patrol police of Ukraine}

Since the adoption of the Act of proclamation of independence of Ukraine, political, economic and social changes have taken place, along with a significant democratization of public relations. A big step in the development of the independent state was the signing of the agreement between Ukraine and the European Union on associate membership on June 27, 2014. One of the important factors of Ukraine's entry into the Commonwealth of European States should be the implementation of a large number of reforms in many spheres of public and political life. One of these reforms was the reform of law enforcement agencies of Ukraine.

The system of internal Affairs of Ukraine was largely built on the achievements of the Soviet Union. In 1990, the law of the Ukrainian SSR "on police" laid the legal basis for the functioning of the modern police of Ukraine. This law until recently was the fundamental document of its activity. However, some questions of activity of militia were settled by other legislative acts. In particular, the issue of the structure of internal Affairs bodies and the number of their employees is regulated by the Law of Ukraine "on the General structure and number of the Ministry of internal Affairs of Ukraine", and the issue of disciplinary proceedings and the Law "on the Disciplinary Statute of internal Affairs bodies of Ukraine". During the independence of Ukraine, large-scale reform did not happen. With each change of state power, there were attempts to modernize the system of internal 
Affairs bodies (only 9 attempts), however, as a rule, the reform process did not give the large-scale, global results that were needed.

In recent years, more and more has been said about the inefficiency of the Ukrainian system of internal Affairs, which is explained by its inconsistency with modern democratic social, economic and political realities. The need to reform the internal Affairs bodies is confirmed by the results of an expert survey conducted by the International center for advanced studies in the period from July to September 2015. Thus, $65 \%$ of respondents recognized the reform of law enforcement agencies as the most important task of the government.

Thus, the European way of development of Ukraine requires a reassessment of the activities of all components of the public authorities, the direction of their functioning to ensure the rights and freedoms of the citizen. A special place is given to the reform of the law enforcement sector, in particular the Ministry of internal Affairs ${ }^{1}$.

All this became prerequisites of creation by the Expert Council of the Ministry of internal Affairs of the Main actions for reforming of law enforcement Agency. On October 22, 2014, the Cabinet of Ministers of Ukraine approved the Concept of reforming the Ministry of internal Affairs and the Strategy for the development of internal Affairs bodies. It became a certain start for the beginning of carrying out strategic reform of militia. Which should result in a new European law enforcement Agency whose mission is to serve and protect.

AcOSACing to the development Strategy of Ukraine 2020, the goal of the state policy in the field of reforming the law enforcement system was to adjust the tasks and functions of law enforcement agencies, the introduction of new principles of service, new criteria for assessing the work of law enforcement officers to improve the protection of human rights and freedoms, as well as the interests of society and the state from illegal encroachments. The new system of the Ministry of internal Affairs is a civil body that forms the state policy in the areas of combating crime and ensuring public security and order (public order), integrated management of the state border, combating illegal migration, civil protection, fire safety and combating emergency situations by creating specialized departments.

Thus, the objectives of the reform of the MIA are:

- demilitarization of the Ministry of internal Affairs;

- reduction of a significant number of bodies, units and services with related tasks and functions;

\footnotetext{
${ }^{1}$ Violence in the family and the police to overcome it: training manual for cadets of higher educational institutions of the Ministry of internal Affairs of Ukraine / compilers: Zaporozhtsev A., Laban A., Zabroda D., Bassist I., Drozdova I., Brizhik V. Kiev, 2012. 246 p.
} 
- ensuring effective coordination of activities and coordinated interaction of the National police, National guard, border, migration services, as well as emergency services under the political leadership of the Ministry of internal Affairs;

- legislative definition of the updated General structure of the Ministry of internal Affairs, structure and number, tasks and powers of internal Affairs bodies and other conditions of their activity, the priorities of which is the implementation of social and service functions;

- depoliticization of the activities of bodies and services controlled by the Ministry of internal Affairs, their autonomy and optimization;

- elimination of duplication of functions of offices, departmental enterprises, institutions and organizations;

- introduction of the European model of training and advanced training of personnel of internal Affairs bodies, application of uniform unified standards of law enforcement training aimed at improving the efficiency of interaction between the internal Affairs bodies of different member States of the European Union;

- development of effective means and mechanisms of control over the activities of internal Affairs bodies and individual police officer;

- increasing public confidence in the activities of the internal Affairs bodies, as well as the authority of the employee of the internal Affairs body;

- increasing the role of civil society institutions and local selfgovernment bodies in measures to ensure the rights and freedoms of the population;

- establishing close cooperation with the population and local communities.

To achieve the above objectives, the following tasks must be performed:

- complete the certification of personnel;

- change of heads of both Central and regional departments of the Ministry of internal Affairs;

- reduction of the administrative apparatus (city administrations);

- reorganization of the special forces unit;

- creation and deployment of the patrol police as a full-fledged structure of public order;

- formation of a unit to combat crimes in cyberspace acOSACing to new principles;

- reorganization of the unit for combating economic crimes;

- liquidation of the unit for combating drug trafficking;

- creation of the expert service independent of regional and district chiefs of the Ministry, that is completely with direct submission to the Minister;

- reforming the National Guard, which will be staffed on the basis of professional requirements exclusively from volunteers; 
- volunteer battalions of the Ministry of internal Affairs will eventually be disbanded, and their members will move to the professional structures of the police and the national guard.

Another point is the formation of the National police as it is the Central Executive body that serves society by ensuring the protection of human rights and freedoms, combating crime, maintaining public security and order, with the following structure: criminal police; patrol police; pre-trial investigation bodies; security police; special police.

The reform of the system of internal Affairs bodies also provides for the adoption of four basic laws: "On internal Affairs bodies", "on the National police", "on services and service centers of the Ministry of internal Affairs of Ukraine", "on amendments to some legislative acts of Ukraine on improving the regulation of relations in the field of road safety" 2 .

The first stage of the reform was the creation of a patrol police. The creation of a patrol police differs from other government initiatives in several points. First, a new institution was created, the selection of personnel in which was transparent, but which should continue throughout the first phase of the reform. As the Georgian experience shows, for the selection of several thousand qualified and uncorrupted employees, several waves of "screening" are needed, since final conclusions about the professional suitability of some personnel can be made only on the basis of their actions in real conditions, and not only during testing and training.

Second, in addition to new institutions, reform requires new procedures, standards and skills. During the training, the emphasis was not on theory, but on the study of about 500 procedures-scenarios in which the new patrol should operate. Thirdly, the key to a new quality of the police should be a high level of salaries and strict internal control mechanisms.

Patrol police in its activity is guided by Constitution of Ukraine, international treaties of Ukraine agreed to be binding by the Verkhovna Rada of Ukraine, laws of Ukraine" On the national police"; "On amendments to some legislative acts of Ukraine on improving regulation of relations in the sphere of ensuring road traffic safety", "On Disciplinary Statute of bodies of internal Affairs of Ukraine"), acts of the President of Ukraine and resolutions of Verkhovna Rada of Ukraine, accepted acOSACing to the Constitution and laws of Ukraine ${ }^{3}$.

\footnotetext{
${ }^{2}$ Code of Ukraine on administrative offences of December 07, 1984 No. 8073-X. sheets of the Supreme Soviet of the Ukrainian SSR. 1984. Annex to No. 51. P. 1122. (with changes and additions)

${ }^{3}$ The administrative activities of the police: a Training manual. Third edition, revised / For zag. edits. Kovalenko V. / Olefir V., Konstantinov S., Bratel S., et al. Kiev: KNT, 2011. 512 p.
} 
Principles of the patrol police of Ukraine. The work of the patrol police is based on the following basic principles: the rule of law; the rule of law; respect for human rights and freedoms; openness and transparency; political neutrality; interaction with society on the principles of partnership and continuity (Section II of the Law of Ukraine "on the National police"). A brief look at their content.

AcOSACing to the principle of the rule of law, a person, his rights and freedoms are recognized as the highest values and determine the content and direction of the state.

The principle of legality is that the police act solely on the basis, within the powers and in the manner prescribed by the Constitution and laws of Ukraine. Police officers are prohibited from carrying out both criminal and illegal orders and orders. Therefore, any orders, orders and instructions of the highest bodies, heads, officials and officials, official, political, economic or other expediency are not a reason for violation by the police of the Constitution and laws of Ukraine.

During the performance of its tasks, the police adhere to and promote the implementation of the principle of respect for human rights and freedoms guaranteed by the Constitution and laws of Ukraine, as well as international treaties of Ukraine, the consent to be bound by the Verkhovna Rada of Ukraine. Restriction of human rights and freedoms is allowed only on the grounds and in the manner prescribed by the Constitution and laws of Ukraine, as necessary and to the extent necessary to perform the tasks of the police. Such restrictions must be a justifiable goal, and therefore must be immediately terminated if the purpose of the application of such measures is achieved or there is no need for their further application ${ }^{4}$.

Police officers are prohibited under any circumstances from facilitating, carrying out, inciting or tolerating any form of torture, cruel, inhuman or degrading treatment or punishment. In case of detection of such actions, each police officer is obliged to immediately take all possible measures to stop them and be sure to report to the direct management of the facts of torture and the intention of their use and notify the pre-trial investigation body authorized to investigate the relevant crimes committed by the police.

In addition, any privileges and restrictions on the grounds of race, color, political, religious and other beliefs, sex, ethnic and social origin, property status, place of residence, language or other grounds are prohibited directly in the activities of the police.

\footnotetext{
${ }^{4}$ Kolpakov V. administrative responsibility (administrative-tort law): studies. benefit. / V. Kolpakov. Kyiv: Yurinkom Inter, 2008. 256 p.
} 
The police operate on the principles of openness and transparency within the limits defined by the Constitution and laws of Ukraine. Which is embodied in the fact that:

- the police shall ensure constant informing of state authorities, local self-government bodies, the public about their activities in the field of protection and protection of human rights and freedoms, combating crime, ensuring public security and order;

- the police shall ensure access to public information of which it is the owner, in the manner and in accordance with the requirements established by law;

- the police may release restricted information only in cases and in the manner prescribed by law;

- normative legal acts regulating the activities of the police must be published on the web-portal of the Central police authority (and with limited access-published in cases and in the manner prescribed by law);

- draft normative-legal acts concerning human rights and freedoms shall be subject to public discussion in accordance with the procedure established by the Minister of internal Affairs of Ukraine.

The principle of political neutrality is that the police ensure the protection of human rights and freedoms regardless of political beliefs and party affiliation, as well as decisions, statements or positions of political parties and public associations 5 .

It is forbidden to use any objects on which the symbols of political parties are depicted and to carry out political activities, to express personal attitude to the activities of political parties during the performance of official duties, as well as to use official powers for political purposes.

The activities of the police are carried out in close cooperation and interaction with the population, territorial communities and public associations on the principles of partnership and are aimed at meeting their needs. The assessment of the level of public confidence in the police is carried out by independent sociological services in accordance with the procedure established by law, and the level of public confidence in the police is the main criterion for assessing the effectiveness of police bodies and units

Principle of continuity. The police ensure the continuous and round-theclock performance of their tasks. Everyone has the right at any time to seek the assistance of police (AOP), and the latter has no right to refuse to consider or to defer consideration of petitions for the rights and freedoms of individuals and legal entities, interests of society and state from illegal encroachments

\footnotetext{
${ }^{5}$ About Central Executive authorities: the law of Ukraine of 17 birches. 2011 No. 3166-VI. Sheets of the Supreme Soviet of the USSR. 2011. No. 38. P. 385.
} 
with reference to weekend, holiday or non-working day or after business hours ${ }^{6}$.

\section{Tasks and functions of patrol police}

The tasks of the National police (which includes the patrol police) are defined in article 2 of the Law of Ukraine "on the National police":

- ensuring public safety and order;

- protection of human rights and freedoms, as well as the interests of society and the state;

- the crime-fighting;

- provision, within the limits defined by law, of assistance services to persons who, for personal, economic, social reasons or as a result of emergency situations, need such assistance.

These are common tasks facing each structural unit of the National police of Ukraine. The special tasks of the patrol police include:

1. Ensuring public order and public safety; ensuring the safety of persons, protection of their rights, freedoms and legitimate interests; creating a state of protection of vital interests of society, concentrated in its material and spiritual values, normal conditions of human life, the activities of enterprises, institutions and organizations.

2. Prevention of criminal and administrative offences; prevention, detection and suppression of criminal and administrative offences, cases of domestic violence, as well as identification of the causes and conditions conducive to their Commission.

3. Interaction with society. Which is the "police and society", which is cooperation and interaction with the public, community organizations, other units of internal Affairs bodies, bodies of public authority, to prevent violations, ensure safety, reduce crime, and build trust between police and the community.

4. Ensuring road safety; organization of control over compliance with laws and other legal acts on road safety.

Patrol service according to the tasks assigned to it carries out:

- round-the-clock patrolling of the service area to ensure proper protection of public order and public safety;

- control over observance of traffic rules in order to ensure its safety and traffic regulation;

- rapid response to reports of offences, as well as timely response to assist citizens to reports of offences;

\footnotetext{
${ }^{6}$ The Constitution of Ukraine of 28 red. 1996 Vedomosti of the Verkhovna Rada of Ukraine. 1996. No. 30. P. 141.
} 
- emergency care;

- providing emergency assistance to victims of accidents, offenses, accidents, fires and other emergencies before the arrival of the competent services;

- self-identification of offences during patrol and in other cases provided by the legislation, draws attention to offences for the purpose of their prevention, suppression, documentation and prosecution;

- termination of criminal and administrative offences, applying for this purpose the rights and powers provided by the legislation:

- review in cases and in the manner prescribed by law, considers cases of administrative offenses and applies administrative measures to offenders;

- detention of offenders and their delivery to divisions of lawenforcement bodies.

- protection of the scene, that is, takes measures to protect and preserve the scene in its original, unchanged condition until the arrival of authorized persons, in particular investigative task forces

- cooperation with other structural units of internal Affairs bodies.

- communication and cooperation with society:

- performance of other powers provided by normative legal acts of the Ministry of internal Affairs.

- other functions aimed at achieving their objectives.

\section{Organization of work of patrol police of Ukraine}

Citizens of Ukraine at the age of 18 years who have complete General secondary education, regardless of race, color, political, religious and other beliefs, gender, ethnic and social origin, property status, place of residence are accepted for service in the police. A prerequisite is the possession of a fluent Ukrainian (state) language. The Ministry of internal Affairs of Ukraine ${ }^{7}$ approves requirements to the level of physical training.

For candidates who are accepted for service in the patrol police, in addition to General, additional requirements are put forward:

- age from 21 to 35 years;

- complete General secondary or higher education;

- availability of a driver's license category b;

- no criminal record;

- fluency in Ukrainian language;

${ }^{7}$ About the statement of Regulations on Department of the organization of activity of divisions of patrol service of special purpose of the Ministry of internal Affairs of Ukraine : The order of the Ministry of internal Affairs of Ukraine of August 11, 2014 No. 809. URL: search.ligazakon.ua/l_doc2.nsf/link1/MVS518.html. 
- physical health and moral stability.

The selection of candidates takes place in several stages: filling out the questionnaire; checking the General level of knowledge; psych diagnostic test; medical examination; checking driving skills; personal interview; theoretical training; professional training. The last two stages are regulated by the Regulation on the organization of courses of primary professional training (specialization) of employees of patrol units, which is approved by the order of the Ministry of internal Affairs of 16.03.2015 No. 276.

Theoretical education and training of patrol officers is in the form of courses on the basis of educational institutions of the interior Ministry, they are assigned to the first special rank of private police) and the probation period up to one year. Students are divided into training groups of no more than 30 people, from which the commander of the group is determined. Students during training may not be involved in the service as part of the daily orders, to maintain internal order in educational institutions, as well as to protect public order After successful completion of training, students receive a document of the established sample, which is attached to their personal files, and are sent to the place of service.

The personnel of the patrol force is equipped with acOSACing to the Provisions on service by ordinary and authoritative bodies of internal Affairs, approved by the decree of the Cabinet of Ministers of the Ukrainian SSR of July 29, 1991 No. 114, the relevant provisions regulating the activities of the divisions of patrol service of the MIA of Ukraine and other normative-legal acts ${ }^{8}$.

The organization of activities, control over the activities of the patrol service is carried out by the head of the Department of patrol service of the Ministry of internal Affairs of Ukraine (hereinafter-STS MIA). The rights and duties of the head of the STS of the Ministry of internal Affairs are determined by the relevant Regulations on the STS of the Ministry of internal Affairs.

The officer of patrol service during performance of the official duties is the representative of the state power. Patrol police work in nonstop mode (around the clock and continuously) two days in two. Two working days consist of two shifts: day - from 7.00 to 19.00 and night-from 19.00 to 7.00. Patrolling is carried out by a police crew which consists of two police officers in clearly defined areas also works and foot patrol. The police are subordinate to the platoon commanders.

\footnotetext{
${ }^{8}$ On the Disciplinary Statute of the National police of Ukraine: law of Ukraine of 15 Mar. 2018 No. 2337-VIII. Official journal of Ukraine. 2018. No. 54. P. 1882.
} 
Employees of the patrol service of the National police have a uniform, badges and distinctions. During the patrol, the police are provided with a rubber baton, a gas canister, a special pocket, a tactical flashlight, handcuffs, a pistol "Fort-17" (9 mm caliber), two magazines and other devices to perform the tasks assigned to them. The patrol police officer has an individual badge with a personal number and a video camera that captures the work of the law enforcement officer. In addition, the police have GPS equipment that captures the movement of patrols and makes it easier to manage them.

They have the right to apply physical force, including unarmed combat techniques to ensure personal safety or the safety of others, suppression of offences, detention of the perpetrator of the offence, if the use of other police measures does not ensure the execution of police powers imposed on it by law. Police officers of the patrol service are authorized to use special means to ensure public safety and order, provided they undergo appropriate special training, and to use service dogs or horses when patrolling.

At the same time, police officers, including those who serve in the patrol police, are prohibited:

- strike rubber (plastic) batons on the head, neck, clavicle, genitals, lower back (coccyx) and stomach;

- during application of the means equipped with substances of tear and irritating action to carry out sighting firing on people, scattering and shooting of grenades in crowd, their repeated application within the zone of defeat during action of these substances;

- to shoot the cartridges equipped with rubber or similar for the properties throwing projectiles of nonlethal action, with violation of certain technical characteristics of requirements concerning distance from the person and firing in separate parts of the head and a body of the person;

- to use means of a compulsory stop of transport for a compulsory stop of motorcycles, sidecars, scooters, mopeds, vehicles engaged in passenger transport, and to apply such funds on mountain roads or roads with limited visibility, level crossings, bridges, viaducts, trestles, tunnels;

- the use of a small explosive device for the opening of premises is justified if the damage caused to the rights and interests protected by law is less than the damage that has been diverted

- apply handcuffs for more than 2 hours of continuous use or without easing their pressure.

Employees of the patrol service are authorized to use firearms in cases of:

- when a person who is detained by a police Officer with a firearm in his hands tries to approach him, reducing the distance determined by him, or touch the weapon; 
- armed attack, as well as in the case of a sudden attack with the use of military equipment, vehicles or other means that threaten the life or health of people;

- if a person detained or arrested for committing a particularly serious or serious crime escapes with the use of a vehicle;

- if a person resists with an armed weapon;

- the need to stop trying to take possession of firearms.

The use of firearms without warning is allowed.

\section{Rights and duties of the inspector of patrol police of Ukraine}

Employees of patrol service of the Ministry of internal Affairs of Ukraine have the right:

- to demand from citizens of observance of public order;

- to demand from the persons violating a public order, the termination of offenses;

- to check at citizens at suspicion in Commission of offenses the documents proving their identity, and also other documents in the cases provided by the law and the way;

- to carry out personal inspection, inspection of things and documents, the vehicle and cargo in the order established by the legislation;

- to withdraw from citizens and officials of subjects and things forbidden or limited in circulation, and also documents with signs of forgery;

- to apply measures of physical influence, special means and firearms in cases and the order provided by the legislation;

- at implementation of patrol on the vehicle to include special light, sound signals, and also in exceptional cases not to observe requirements of traffic rules;

- temporarily restrict or prohibit access of persons to a certain territory or objects, if it is necessary to ensure public order and public safety, protection of life and health of people, as well as to conduct certain investigative actions in accordance with the legislation;

- to restrict or prohibit in cases of detention of criminals at accidents, other emergency circumstances threatening life and health of people, movement of vehicles and pedestrians on separate sites of streets and highways acOSACing to the legislation;

- to use technical means and technical devices for detection and fixing of offenses acOSACing to the legislation;

- to detain citizens on the grounds and in accordance with the law and to deliver them to the internal Affairs bodies in accordance with the legislation;

- delay and ensure delivery of vehicles for temporary storage in accordance with the legislation. 
Duties of employees of patrol service:

- strictly observe the provisions of the Constitution of Ukraine, laws of Ukraine and other legal acts regulating the activities of the police, and The oath of the police;

- professionally perform their duties in accordance with the requirements of legal acts, official (functional) duties, orders of management;

- respect and not violate human and civil rights and freedoms;

- to render urgent, in particular do medical and medical, help to persons who suffered as a result of offenses, accidents, and also to the persons who appeared in a helpless condition or a condition dangerous for their life or health;

- keep information with limited access, which became known to him in connection with the performance of official duties;

- to inform the direct head of the circumstances precluding his further service in the police or stay in office.

- restrict human rights and freedoms only in the manner and in cases established by law;

- referring to the person, say Hello, put his right hand to the headdress, to give his name, position, special rank and produce on request official identity, providing an opportunity to see it with the above information, while not letting him out of my hands;

- during communication with the person to observe accurately norms of office ethics;

- to warn drivers of vehicles of the danger which has arisen on the way of their movement, and to take measures for their elimination;

- during carrying out repair and construction and other types of works on streets and roads to provide optimization of traffic and to control observance of rules of traffic safety;

- if possible, to assist the driver in case of malfunction of his vehicle;

A police officer on the entire territory of Ukraine, regardless of the position he holds, location and time of day, in the event of any persons contacting him with a statement or report on events threatening personal or public safety, or in the case of direct detection of such events, is obliged to take the necessary measures to save people, provide assistance to persons who need it, and report this to the nearest police authority.

The employee of patrol service is forbidden:

- violate the rules of the road and the rules of improvement, if it is not related to the need to perform official activities;

- communicate with people while in a service vehicle;

- give directions or wishes to road users with incomprehensible gestures, use a loudspeaker or special signals for other purposes; 
- identify disrespect or ill will towards citizens;

- other that is provided by the legislation, including normative legal acts of the Ministry of internal Affairs.

In case of Commission of illegal acts, police officers bear criminal, administrative, civil and disciplinary responsibility according to the law.

\section{Basic principles of police protection}

The security police is the only security structure in Ukraine, whose employees have the rights and powers defined by Law for armed protection and the use of power functions for offenders. After the establishment of the National police, legal entities and individuals who used the services of the State security service came under the protection of the security police.

August 10, 1993 Decree of the Cabinet of Ministers of Ukraine No. 615 "About measures on improvement of protection of objects of state and other forms of ownership", on the basis of units of the security at internal Affairs bodies, the State security service under MIA of Ukraine, which acted on a self-financing basis.

The service was entrusted with the protection of particularly important state objects, the duties of the law enforcement State service and a set of paid security services that have developed in market conditions.

During 1993-1998, the State security servise (SSS) Department addressed a range of personnel, legal, technical, financial, economic and other issues, developed and implemented policy directions for the further development of the security service, it is planned to improve management and develop a regulatory framework, strengthen the economic condition, carry out technical re-equipment and ensure the reliability of protection, improve logistics and improve personnel management.

Given the complexity of the economic situation, which turned out to be security, work was done to improve the system management units, which was now aimed at improving security and strengthening the economic condition of the units. This allows the system of the State security service under MIA of Ukraine was created in service of the special police protection "Titan", a collection Service, the protection of banknotes and securities and the Commission for tender for special armored vehicles that were used for collection and transportation of values. Thus, in June 1998, 95 regular units of the collection Service were established in the SSS system, with which 13764 contracts were concluded. For five years of the existence the regular number of special forces of militia of protection "Titan" reached 3 thousand people who carried out about 9 thousand security actions on support of valuable freights, papers and money, carried out protection of property of legal entities and personal safety of physical persons, rendered complex protection of objects and so forth. Also reorganization of organizational and 
staff structure was carried out, personnel apparatuses were reformed, thanks to what the Concept of uniform system of professional training of a category of personnel of the State security service was realized.

Subsequently, the centre was established to provide informational support for subdivisions of the bonds, the system of the local computer network HUDSO and email system at the level of the "Center-region", developed the Concept of management of advertising activities and the Regulation on promotional activities of SSS Ministry of internal Affairs of Ukraine ensured the publication of materials in mass media about the activities of the departments of SSS, he began producing a variety of promotional and souvenir products.

18 December 1998 based on the existing legal framework and legislative acts of Ukraine in connection with the order SSS at the interior Ministry of Ukraine in the Department of State security service it was decided to open a Museum of the history of SSS.

Defined in 2000 by the Ministry of internal Affairs Board of Ukraine areas continues the process of restructuring the organizational structure of SSS, its financial-economic activities, the introduction of new technical means of protection, the Institute of civic guards, and the exemption of the police from performing irrelevant tasks, separation of power and self-supporting functions.

On the way of such transformations, the number of employees of the administrative and managerial apparatus was significantly reduced, unnecessary management links disappeared, and unprofitable divisions were liquidated.

It was also extremely important that considerable attention was paid to the training of personnel. Eight training programs for initial training, retraining and advanced training of security personnel have been developed and implemented. Such important tasks as special training of employees for protection of schools and preschool institutions, specialists in marketing and sales of security services on which further development of service, its competitiveness largely depended were solved.

Currently, the Department has carried out operational tests and introduced a new generation of centralized surveillance systems, such as: "Chestnut", "signal", "Ozone", "Integral", "alpha", "Danube", receiving and control devices VBD-6, Is-8001, etc. In order to ensure the protection of telephoned objects, radio monitoring was introduced.

Within the limits of the powers, the State security service carried out licensing of services in protection by non-state security formations. To ensure the high quality of security services and social protection of employees in the State security service created Ukrainian security and insurance company "USC". 
In June 2007, the State security service consisted of 192 combat units, 146 collection services, 38 Special Forces units "Titan" and other services, which employed more than 48 thousand employees. It is possible to note also considerable material and technical potential of service: 251 points of the centralized supervision, modern means of communication, Park of special cars, the newest firearms. Specialized educational institutions, one secondary and two higher vocational schools have been established to train employees in the SSS. Under protection of Service there were more than 177 thousand objects among which 86800 housing of citizens. At the same time, 486 detention groups took over the service, which prevented about 37 thousand crimes and detained more than 40 thousand criminals. Elite divisions of SSS "Titan", in turn, provided support of freights and values, safety of the Ukrainian and foreign citizens (290 physical persons).

November 7, 2015 according to the Law of Ukraine "On the National police" and the decree of the Cabinet of Ministers of Ukraine from 13 October 2015 No. 834 "Questions of functioning of police protection as territorial bodies of the National police and the elimination of some territorial bodies of the Ministry of internal Affairs", was created by a police Department protection, as well as control and police protection as the regional offices of the National police. The security police has more than 200 centralized security consoles, modern communications equipment, a fleet of special vehicles, the latest firearms.

All protected objects with the help of technical means are connected to centralized security panels. Units of the security police are equipped with alarm buttons and relevant information labels 3085 emergency call places. For the organization of remote control of the operational situation in places of mass stay of citizens, 604 video surveillance systems are installed. Detention groups-mobile squads round the clock patrol the cities and regions of Ukraine. At the same time, about 500 detention groups take over the service.

In 2009 under protection there were almost 95 thousand objects and over 92,5 thousand dwellings of citizens (apartments, offices, shops, shopping centers, strategic objects, country houses and so forth). The guard police are part of the National police. The Cabinet of Ministers of Ukraine by its resolution No. 834 of 13 October 2015 established as territorial bodies of the National police the Department of police protection as an interregional territorial body of the national Police; The police Department of protection of objects of strategic importance, as well as police protection in areas of Kiev, the Autonomous Republic of Crimea and Sevastopol, Kryvyi Rih city Department police protection in the Dnipropetrovsk region, the Mariupol Interdistrict Department of management of police protection in the Donetsk region, as well as police protection to physical security in Kiev. To protect 
individuals, goods and valuables, property of individuals and legal entities in the structure of the security Police there are physical security units ${ }^{9}$.

\section{Special police}

OSAC (ADB. from the Operational-Sudden Action Corps) - a unit of the National police to deal with emergencies, the level of which is so high and complex that it may exceed the capabilities of the rapid response forces or operational search units.

On March 12, 2015, interior Minister Arsen Avakov in his report "100 days of Government activity: the way to stabilization" said that on the basis of special purpose battalions and special forces of the interior Ministry will be created a single special purpose unit and it will be called OSAC (Corps of operational and sudden action).

On March 4, 2016, the first 37 fighters of group "A" of Special Forces OSAC, after a rigorous selection and two-month training course, began to perform their duties. The head of the National police Hatia Dekanoidze noted that today is another historic day in the history of the National police of Ukraine. With the support of American partners, the first commandos who were selected among 900 candidates received certificates of completion of the training course. During the two-month training course, they adopted the experience and tactics of police special operations of the drug enforcement administration (DEA) of the U.S. Department of justice and the bortac border patrol. Eighty percent of the course was practical. The practical part includes classes on fire training, which is the basic discipline, as well as tactics in extreme conditions, in particular, indoors and in the forest. In addition, the candidates received skills of sniping, knife fighting, and tactics of action in the detention of criminals using cars. The theory included the study of the legal basis of the police special forces, familiarization with the qualification of crimes, the passage of psychological training.

On March 17, 2016, as part of the creation of the witness protection program, the first trainings with US Marshal were launched as part of the OSAC of the national Police. In addition, in two weeks 17 instructors of group "U" of Special Forces "OSAC" of National police of Ukraine received certificates of completion of training. Also on this day, 1 April, began the selection of candidates for the unit "OSAC" throughout Ukraine. The special unit is planned to recruit 3076 police officers.

\footnotetext{
${ }^{9}$ The administrative activities of the police in questions and answers: textbook / for zag. ed. Sciences, prof., Acad. National Academy Of Legal Sciences Of Ukraine O. Bandurka. Ministry of internal Affairs of Ukraine, Kharkiv. NATs. UN-t EXT. cases'. Kharkiv: HNUVD, 2017. 242 p.
} 
On July 22, 2016, a representative of the FBI handed Ukrainian soldiers certificates of completion of the basic course with the use of special weapons and tactics. For 10 days instructors of the Federal Bureau of investigation of the USA shared experience of detention of violators of a law and order with fighters of police Special Forces OSAC.

In General, in 2016, the special unit OSAC began its work in Kiev, Kiev, Sumy, Kharkiv, Donetsk and Rivne regions. A special role was assigned to the units in the last two areas, for the specifics of work in the frontline settlements of the Donetsk region and the fight against the amber mafia in the Rivne region.

On January 31, 2017, soldiers of the Special Forces OSAC together with the police regiment "Kiev" and the special purpose battalion of the criminal and preventive units of the GUNP in the Donetsk region were sent to the frontline city of Avdiivka, which was attacked by militants and gangs the day before. All fighters have experience in combat and proper training. Among the tasks of law enforcement officers to preserve law, order, and prevent looting. For service in the line of fire, the police are provided with special vehicles.

On May 28, 2017, a special unit OSAC was sent to Krasnogorovka, Donetsk region, shelled by terrorists, to assist citizens, as well as to strengthen the protection of public order and destroyed administrative buildings. The regional police Department reported that the commandos will serve to protect public order, evacuate people on armored vehicles if necessary, to carry out anti-terrorist activities ${ }^{10}$.

On June 22, 2018, the 14th edition of the soldiers of the special purpose police units OSAC in Cherkasy and Ternopil regions took place. This issue completely completed the formation of the territorial divisions of OSAC in Ukraine.

Tasks OSAC:

- develops, prepares and conducts special operations to capture dangerous criminals;

- stops offences committed by members of criminal groups;

- release the hostages;

- provides power support during operational search activities, investigative (search) and secret investigative (search) actions, as well as measures to ensure criminal proceedings;

- providing support to other police units with the goal of providing superior firepower of the offenders;

\footnotetext{
${ }^{10}$ Provision by the internal Affairs bodies of international legal standards of human rights in the protection of public order. Scientific-practical, documentary-source and educationalmethodical complex (in 3 parts). Kyiv: Institute of state and law. V. Koretsky NAS of Ukraine, 2010. $460 \mathrm{p}$.
} 
- participates in anti-terrorist operations conducted by the anti-Terrorist center under the security Service of Ukraine;

- studies, summarizes domestic and foreign experience, as well as the methodology of similar foreign units in this area of work;

- ensures the implementation of security measures for persons involved in criminal proceedings.

The greatest need to attract OSAC has a criminal unit MDNP in the Donetsk region, in a region where since 2014 there is a war, where there is a large number of weapons, ammunition, and where people who commit crimes can be armed. In the absence of Special Forces to perform special operations to detain criminals participated special battalion MDNP in the Donetsk region.

In the structure of the regional Central Board of the Donetsk region formed units OSAC, which has more than 100 people, has a duty unit, headquarters, staff instructors, inspection Department, analysts who develop special operations, and directly-a special forces team of 70 people.

On October 28, 2016, the first 17 members of the police special forces completed the training course and received OSAC certificates. This is the assault squad, whose task in combat is neutralization prospecting groups of the opponent, the detention of terrorists, the release of the hostages. Most of them - fighters of the former "Falcon", have experience of service in the conditions of anti-terrorist operation and took direct part in special operations on the demarcation line.

In addition, OSAC units take part in all-Ukrainian anti-terrorist exercises together with the SBU, NSU and GNSU units. So in 2016, joint exercises were held to liberate the Embassy of the state of Israel in Kiev, the international airport "Boryspil", Kharkiv regional state administration and other important objects of national and international importance.

On November 21, 2017, joint exercises of Special Forces of the National Guard of Ukraine - "omega", The state border service - "Dozor" and the National police of Ukraine "OSAC" were held at the training ground of the National guard of Ukraine in Novy Petrovtsi, Kyiv region, with the technical assistance of the US Government. The commandos worked out the elements of a parachute landing from a helicopter with the use of various equipment, and established the evacuation of the group from a given area with the help of a special rope.

According to the state special unit, "OSAC" consists of Department and managements "OSAC" MDNP in and Kiev, in total-1206 police officers.

Special operations units are staffed on a voluntary and contractual basis.:

1. They have experience of practical work (service) in the internal Affairs bodies, the National police, the Armed forces, the security Service of Ukraine for at least three years. 
2. Took part in carrying out anti-terrorist operation as a part of the divisions formed according to the legislation of Ukraine.

3. Were interviewed by the leadership of the Department of OSAC.

4. They underwent special psychological and medical examinations, acOSACing to the results of which they were recognized as fit for service in special operations units.

5. Successfully passed the standards for physical training and passed a five-day endurance course.

6. Passed specialized training in The Department of organization of the Corps of operational and sudden action and successfully passed the exams.

The candidate (with his consent) to fill the vacancy in the Department of special operations of the special unit OSAC can be surveyed by specialist services using computer polygraph.

The "OSAC" team gear is designed for a variety of special situations, including close combat in an urban environment. Commandos are provided with summer (camouflage MULTICAM) and winter (camouflage NATO a-ODU AU) uniforms and shoes of the established sample, as well as personal protective equipment (gas masks, helmets, body armor, shockproof and bulletproof shields, protection for hands and feet).

OSAC units use pistols, submachine guns, carbines, shotguns and sniper rifles. Tactical AIDS such as police dogs stun grenades and tear gas grenades.

As of the beginning of 2016, special forces soldiers OSAC received pistols Glock 17 and Jericho 941, shotguns "Fort-500", machine guns "Fort-221", "Fort-224", carbines "Z-10", "Z-15", machine guns "Fort-401", hand grenade launchers "Fort-600", sniper rifles "Fort-301" and Barrett M107A1.

For rapid hacking doors (castles, hinges or destruction the entire door frame) can use battering rams, shotguns with destructive charges, explosive packages.

While ensuring public safety at mass events, OSAC teams also use nonlethal weapons: pepper spray canisters, shotguns with rubber charges, weapons firing pepper balls, tear gas grenades, and stun grenades.

Fighters of group "A" (assault groups) for work on a line of fire are provided with special transport: armored cars "VARTA" which were developed specially for special purpose police and the modernized BRDM-2 which are used only in special operations in a zone of military operations in the East of Ukraine.

Suspects also use modified buses, vans, trucks and other vehicles that look like regular vehicles to avoid detection during operations. In particular, it is armored Toyota Land Cruiser, Volkswagen T6, and Peugeot Boxer. 
In addition, the police actively use helicopters for aerial reconnaissance, transportation of personnel, wounded or detained. For this purpose at the disposal of Special Forces, there are mi-8MSB-B helicopters.

\section{CONCLUSIONS}

The creation of the patrol police is the first example in Ukraine, when changes in legislation were combined with an attempt to create a new institution and innovations such as transparent selection of employees, their training in new procedures, standards and skills, as well as appropriate financial support. This is a large-scale step towards reforming the internal Affairs bodies, which consists of completely new employees seeking qualitative changes.

More modern technical devices, which are used by employees of patrol service, allow them to react quickly to offenses, and also to warn and reveal them.

Companies and battalions of special purpose are created mainly for the protection of public security and order. Laws and other legal acts regulate the list of special purpose police units and its functions. A separate stage of the reform of the internal Affairs bodies is the creation of the corps of operational and investigative actions. A high level of physical training and possession of special skills that allow them to perform the tasks assigned to them characterize special police officers.

Thus, the State security service and special purpose police units perform extremely important functions, including ensuring public order and public security. Relations of divisions of the State security service with legal entities and citizens in connection with provision of services in protection and safety, responsibility, the rights and duties of the parties are defined by contracts, and services which it provides-paid.

\section{SUMMARY}

The article reveals the legal regulation and principles of the patrol police of Ukraine, the principles of the patrol police of Ukraine, the tasks and functions of the patrol police, the organization of the patrol police of Ukraine, the rights and duties of the inspector of the patrol police of Ukraine, the basic principles of the security police, the special purpose police

\section{REFERENCES}

1. Administrative activities of the police of Ukraine: textbook / ed. Sciences, Assoc. V. Sokurenko; Ministry of internal Affairs of Ukraine, Kharkiv. NATs. UN-t EXT. cases'. Kharkov: HNUVD, 2017. 432 p.

2. The administrative activities of the police in questions and answers: textbook / for zag. ed. Sciences, prof., Acad. National Academy of Legal 
Sciences Of Ukraine O. Bandurka. Ministry of internal Affairs of Ukraine, Kharkiv. NATs. UN-t EXT. cases'. Kharkiv: HNUVD, 2017. 242 p.

3. Administrative activities: studies. benefit. for students. in Moscow. Studies'. zacl. / Ed. collective: M. Kovaliv, Z. Kisil, D. Kalayanov, etc. Kyiv: legal unity, 2009. $432 \mathrm{p}$.

4. Administrative (police) activities of the police: General part: Textbook. Second edition / ed. V. Kovalenko, Y. Rymarenko, V. Olefir Kyiv: "Direct Line", 2012. $816 \mathrm{p}$.

5. The administrative activities of the police: a Training manual. Third edition, revised / For zag. edits. Kovalenko V. / Olefir V., Konstantinov S., Bratel S., et al. Kiev: KNT, 2011.512 p.

6. Violence in the family and the police to overcome it: training manual for cadets of higher educational institutions of the Ministry of internal Affairs of Ukraine / compilers: Zaporozhtsev A., Laban A., Zabroda D., Bassist I., Drozdova I., Brizhik V. Kiev, 2012. 246 p.

7. The administrative activities of the police in questions and answers. Textbook. Kyiv: PE "Direct Line", 2012. 224 p.

8. Kurennoy E. Legal and organizational bases of activity of patrol service of the Ministry of internal Affairs of Ukraine: Uch. - method. possib. I E. Kurennoy, D. Zabroda, Dnepropetrovsk: Dnepropetr. state University EXT. del, 2009. 104 p.

9. Provision by the internal Affairs bodies of international legal standards of human rights in the protection of public order. Scientific-practical, documentary-source and educational-methodical complex (in 3 parts). Kyiv: Institute of state and law. V. Koretsky NAS of Ukraine, 2010. 460 p.

10. Mechanisms of interaction between state authorities and nongovernmental organizations in combating child abuse. Educational and methodical manual (ed. Shevchenko K., Trubavina I. Kiev: legal Counsel. 2005. $452 \mathrm{p}$.

11. Kolpakov V. administrative responsibility (administrative-tort law): studies. benefit. / V. Kolpakov. Kyiv: Yurinkom Inter, 2008. 256 p.

12. Mironyuk, G. bodies of internal Affairs as subjects of the enforcement proceedings on cases of administrative offences: proc. benefit. / R. Mironyuk, S. Goncharuk. - Dnepropetrovsk: Dnepropetr. state University EXT. del, 2006. 96 p.

13. Administrative responsibility in Ukraine: studies. no. / V. Gumenyuk, G. Yagupov, O. Salmanova, etc.; for the General editorship of A. Kasuka. Kharkiv: HNUVD, 2007. 80 p.

14. The Constitution of Ukraine of 28 red. 1996 Vedomosti of the Verkhovna Rada of Ukraine. 1996. No. 30. P. 141. 
15. About Central Executive authorities: the law of Ukraine of 17 birches. 2011 No. 3166-VI. Sheets of the Supreme Soviet of the USSR. 2011. No. 38. P. 385 .

16. On the National police: law of Ukraine of 02 July 2015 URL: http://www.zakon1.rada.gov.ua.

17. On the prevention of domestic violence: the law of Ukraine of January 15. 2001 Vedomosti of the Verkhovna Rada of Ukraine. 2002. No. 10. P. 70.

18. On prevention of corruption: law of Ukraine No. 1700-VII of 14 October 2014. Voice of Ukraine from 25.10.2014 № 206.

19. On the purification of power: law of Ukraine of September 16, 2014 No. 1682-VIII. Information of The Verkhovna Rada. 2014. No. 44. P. 2041.

20. On the Disciplinary Statute of the National police of Ukraine: law of Ukraine of 15 Mar. 2018 No. 2337-VIII. Official journal of Ukraine. 2018. No. 54. P. 1882.

21. About the state secret: the law of Ukraine of January 21, 1994. No. 3855-XII. Sheets of The Verkhovna Rada of Ukraine. 1994. No. 16. P. 93 (as amended).

22. About addresses of citizens: the law of Ukraine of 02 Oct. 1996 No. 393/96. Sheets of The Verkhovna Rada of Ukraine. 1996. No. 47. P. 256 (as amended).

23. About public associations: the law of Ukraine of March 22. 2012, No. 4572-VI. Sheets of The Verkhovna Rada of Ukraine. 2013. No. 1. C. 1.

24. About information: law of Ukraine of 02 Oct. 1992 No. 2657-XII. Sheets of The Verkhovna Rada of Ukraine. 1992. No. 48. P. 650 (as amended).

25. About access to public information: the law of Ukraine of January 13, 2011 No. 2939-VI. Sheets of The Verkhovna Rada of Ukraine. 2011. No. 32. P. 314

26. On local state administrations: Law of Ukraine No. 586-XIV of 09 April 1999. Sheets of The Verkhovna Rada of Ukraine. 1999. No. 20-21. P. 190.

27. About judicial system and the status of judges: the Law of Ukraine: from June 2. 2016 No. 1402-VIII. Official journal of Ukraine. 2016. No. 56.

28. On the participation of citizens in the protection of public order and the state border: the law of Ukraine of 22 June. 2000 No. 1835-III. Official journal of Ukraine. 2000. No. 30. P. 1248.

29. On international treaties of Ukraine: law of Ukraine of June 29. 2004 No. 1906-IV. Sheets of The Verkhovna Rada of Ukraine. 2004. No. 50. P. 540.

30. Code of Ukraine on administrative offences of December 07, 1984 No. 8073-X. sheets of the Supreme Soviet of the Ukrainian SSR. 1984. Annex to No. 51. P. 1122. (with changes and additions) 
31. About the statement of Regulations on the Ministry of internal Affairs of Ukraine: the resolution of the Cabinet of Ministers of Ukraine of August 13, 2014 No. 401. Uryadovy courier from 10.09.2014. No. 165.

32. About formation of some territorial bodies of the Ministry of internal Affairs: The Resolution of the Cabinet of Ministers of Ukraine of May 20, 2015 No. 314. URL: http://ligazakon.ua/1_doc2.nsf/link1/KP150314.html

33. About the statement of the Order of consideration of addresses and messages concerning abuse of children or threat of its Commission: the Order of Ministry of social Policy of Ukraine, the Ministry of internal Affairs of Ukraine, MES of Ukraine of August 19, 2014 No. 564/836/945/577. Official Bulletin of Ukraine from 03.10.2014. 2014. No. 77. P. 409, p. 2214.

34. Instruction on the organization of activities of duty units of bodies and divisions of internal Affairs of Ukraine aimed at protecting the interests of society and the state from illegal encroachments: order of the Ministry of internal Affairs of Ukraine of 28 APR.2009 No. 181. URL: http://www.zakon1.rada.gov.ua.

35. About the statement of Regulations on Department of the organization of activity of divisions of patrol service of special purpose of the Ministry of internal Affairs of Ukraine: The order of the Ministry of internal Affairs of Ukraine of August 11, 2014 No. 809. URL: search.ligazakon.ua/ 1_doc2.nsf/link1/MVS518.html.

36. About the statement of Regulations about the patrol service of the interior Ministry: the order of MIA of Ukraine from July 02, 2015 No. 796 (is Registered in Ministry of justice of Ukraine 03.07. 2015 No. 777/27222). URL: www.zakon1.rada.gov.ua.

37. On approving the Instructions on registration of employees of patrol service of the interior Ministry materials on administrative violations in the sphere of ensuring road safety: the order of the MIA of Ukraine of July 10, 2015 No. 842. URL: //search.ligazakon.ua/l_doc2.nsf/link1/RE27275.html

38. About the statement of rules of conduct and professional ethics of persons of ordinary and commanding structure of police of Ukraine: The order of the Ministry of internal Affairs of Ukraine of February 22. 2012 No. 155. Official Bulletin of Ukraine from 21.05.2012. No. 36. P. 342.

39. About questions of application of the administrative legislation of Ukraine by bodies of internal Affairs of Ukraine: the order of the Ministry of internal Affairs of Ukraine of October 04, 2013 No. 950. URL: www.zakon1.rada.gov.ua.

40. About the statement of the Instruction on accounting of administrative offenses: the order of the Ministry of internal Affairs of Ukraine of November 07, 2012 No. 1017. URL: www.zakon1.rada.gov.ua. 
41. Approval On approval of the Instruction on organization of activity of district police officers [Electronic resource]: the order of MIA of Ukraine from 28.07.2017, No. 650 (Registered in Ministry of justice of Ukraine 21.08.2017, No. 1041/30909). URL zakon3.rada.gov.ua/laws/show/z1041-17.

42. About the organization of response to messages on criminal offenses, other offenses, emergency situations and other events and providing operative informing in bodies and divisions of internal Affairs of Ukraine: The order of the Ministry of internal Affairs of Ukraine of October 22. 2012 No. 940. Official journal of Ukraine. 2012-No. 9. C. 105. C. 350.

\section{Information about the author: Rachinska I. M.,}

Candidate of Law, Associate Professor, Associate Professor at the Department of Administrative,

Criminal Law and Procedure, International University of Business and Law 37-A, 49 HGD str., Kherson, 73040, Ukraine 


\section{LEGAL SIGNIFICANCE OF THE CONCEPT "ACADEMIC INTEGRITY"}

\section{Tytska Ya. O.}

\section{INTRODUCTION}

Task statement and relevance of the research subject. The requirements, which the life sets today towards the professional training of individuals, receivers of education services, necessitate the strengthening of methodological educational fundamentals as a whole. Dynamic development of the legislation, particularly the consolidation of new categories in the Laws of Ukraine "On Education", "On Higher Education" etc., which incline to come to grips with their methodological role and legal significance both for the entire system of domestic education and specific participants of the educational process, should be arranged with the provisions of other statutory instruments that regulate related social relations. The legal concepts and definitions have become more relevant for the formation of professional awareness of a scholar. This is linked with the implementation of some provisions of the European Union, including the education sector, in the domestic legislation and the need overall to reflect the complexity of perception of general vectors in training support and activities of education seekers at different levels, scientists according to the principles acting in the EU countries. These problems become complicated in the domestic legal environment that has been highlighted and is highlighted by scholars.

However, the consolidation of individual concepts in the Laws of Ukraine "On Education", "On Higher Education" needs reinterpretation. For example, the concept "academic integrity" is not just a criterion for compliance with a certain standard of behaviour but a direction for a radical reform of the education system in Ukraine. The conclusions on the conceptual nature of the mentioned concept can be drawn from the analysis of part 1 marked 1 of Article 1 of the Law of Ukraine "On Education" which indicates that academic integrity is a set of ethical principles and rules defined by this Law and other laws of Ukraine, which should be followed by the participants of the educational process during learning, teaching and conducting scientific (creative) activities in order to ensure reliance in the learning outcomes and/or scientific (creative) achievements ${ }^{1}$. Moreover, such a concept reflects an

${ }^{1}$ Про освіту: Закон України / Відомості Верховної Ради (ВВР), 2017, № 38-39, ст. 380. URL: http://zakon.rada.gov.ua/laws/show/2145-19 
element of training of achievement-oriented human capital and acts as a major part of the foundations of the functioning of the higher education system in Ukraine - efficiency. Thus, in the context of observing (supporting) "academic integrity", it is possible to attain some tasks of the Law of Ukraine "On Education", including innovation-driven development, personal selffulfilment, meeting the demands of society, labour market and state for skilled professionals etc ${ }^{2}$.

Analysis of recent research and publications. The category of integrity is newish in domestic legal science. Many research papers are devoted to the issue of "integrity", including ones of L. Prudyus, L. Kurochka et al. The scientific efforts of I. Fedorovych, T. Semkiv, L. Zuieva, S. Hlushchenko et al. cover the problems of the integrity of judges. The research subject becomes topical in the process of applying the term "integrity" under the conditions of modification of the legislation in the education sector.

\section{Definition of the term "integrity" and "academic integrity"}

Having recourse to reference literature, it is essential to mark that the term "integrity/chastity" (Church Slavic: pudicity, moral and carnal purity, virtue, Latin: castitas) is a moral quality and honesty that is expressed in carnal purity in all its manifestations (as a rule, this concept is more typical for secular societies). Integrity is a positive opposite of sexual incontinence, adultery, lascivious behavior, and nowhere more so than in singledom. Lust (craving, Latin: luxuria) is contrary to integrity ${ }^{3}$. Thus, the analysed concept is intended to specify a complex of moral qualities of the individual. In such a framework, "integrity" is considered by some Ancient Greek philosophers. Among others, Socrates interpreted the above term as a conscious and responsible attitude of the individual to his lifestyle, principally moral behaviour. Integrity means a capability to be ruled by own beliefs and to resist to misconceptions of others ${ }^{4}$. Now, the mechanisms of academic integrity and tools of pathology counteraction are implemented in the internal programme documents on research ethics and statutory principles and introduced into the text of laws and regulations in the area of scientific policy in Europe. It is interesting to note that unlike the USA where integrity is academic and covers all functioning spheres of higher education institutions and scientific establishments and, in Europe, integrity becomes more relevant in the very

${ }^{2}$ Про вищу освіту: Закон України / Відомості Верховної Ради (ВВР), 2014, № 37-38, ст. 2004. URL: http://zakon.rada.gov.ua/laws/show/1556-18

${ }^{3}$ Етимологічний словник української мови: У 7 т. / Редкол. О. С. Мельничук (голов. ред.) та ін. К.: Наук. думка, 1983 Т. 6: / Уклад.: Г. П. Півторак та ін. 2012. 568 с.

4 Лис В. Про Сократа, Данила Галицького, Фернандо Магелана, Ісаака Ньютона, Шарлотту, Емілі, Енн Бронте. К. : Грані-Т, 2008, С. 27-28. 
context of research activity that determines the use of term "research integrity" in the key documents and declarations related to the development of European research space and scientific policy in the EU and funding programme for research "Horizon 2020" in particular".

In Ukraine, the above concept embraces not only the research process (conducting of scientific, creative activity) but also centres on the training and teaching (in all education institutions) like in the United States.

\section{2. "Integrity" as a category of legal science}

"Integrity" as a category of legal science is used in the anti-corruption legislation. Thus, the Center for Support of Civil Service Institutional Development proposes to define integrity as a course of conduct of a civil servant on the protection of public interest and his refusal of meeting individual private interests while realizing his governmental powers ${ }^{6}$. In the Law of Ukraine "On the Principles of State Anti-Corruption Policy in Ukraine (the Anti-Corruption Strategy) for 2014-2017", "integrity of assets of officials" is a part of the recommendations of Group of States Against Corruption (GRECO) and the EU, and the effectiveness of corruption prevention and combating directly depends on bringing in line with "integrity standards" for individuals who hold elective positions. Moreover, one of the key elements for supporting integrity in the civil service (integrity system of the public service) is legislation reformation. Therefore, the reasons are as follows: a) non-compliance with international standards and best global practices; b) remuneration (components of salaries, transparency and motivation of remuneration); c) responsibility nature, etc ${ }^{7}$. In order to achieve integrity, it is adopted the Law of Ukraine "On Rules of Ethical Conduct" and a range of branch Codes of Ethical Conduct which are aimed at, according to Article 12 of the Law, shaping a positive image, contributing to the confidence building, honesty consolidation, impartiality and effectiveness. It also should be marked the availability of the provision on the responsibility of individuals who violate the rules of ethical conduct. In line with Article 18 of the analysed regulatory legal act, the specified individuals bear disciplinary, administrative, criminal, pecuniary liability, taking into account their legal

5 Академічна доброчесність: проблеми дотримання та пріоритети поширення серед молодих вчених : кол. моногр. / за заг. ред. Н. Г. Сорокіної, А. Є. Артюхова, І. О. Дегтярьової. Дніпро : ДРІДУ НАДУ, 2017. С. 129.

6 Україні - європейські принципи державної служби : буклет. К. : ГУДС, Центр сприяння інституційному розвитку державної служби. 2006. 7 с.

7 Про засади державної антикорупційної політики в Україні (Антикорупційна стратегія)" на 2014-2017 роки : Закон України. Відомості Верховної Ради (ВВР), 2014, № 46, ст. 2047 URL: http://zakon3.rada.gov.ua/laws/show/1699-18 
status $^{8}$. Moreover, the concept "integrity" is not defined within the framework of anti-corruption legislation in Ukraine, along with its wide use. Integrity, as a category of anti-corruption legal regulation, doesn't have clear content and internal architectonics. The above conclusions is confirmed by the Resolution of the Cabinet of Ministers of Ukraine dated April, 29, 2015 No. 265 "On Approval of the State Program for Implementing the Principles of State AntiCorruption Policy in Ukraine (Anticorruption Strategy) for 2015-2017 in which the fifth point of the section "Expected results, effectiveness of the Program" marks the creation of an effective mechanism of prevention of corruption, conflict of interests, violation of ethical conduct standards and emphasizes maintenance of control over the adherence to rules of the integrity of individuals (public servants, officials of local authorities, others) ${ }^{9}$. Consequently, following the line of thinking of the Program's authors, the abovementioned elements, which will make it possible to carry out an effective control and compose the content of the term "integrity, should become constituents of integrity. However, taking into account the above, according to the Program (point 5 of the section "Expected results, effectiveness of the Program"), it is significantly narrowed the structure of entities, whose activities are directed towards integrity control because that sort of task is exercised by the National Agency on Corruption Prevention under the Law of Ukraine "On Prevention of Corruption" and the analysed Plan. Other listed entities, which are entrusted to perform anti-corruption activities, are not intended to control "civil servants integrity" under the Law of Ukraine "On Prevention of Corruption"10.

The concept "academic integrity", which is seen at the new version of the Law, consists of two main parts: 1) as a set of ethical principles; 2) as rules defined in the Law of Ukraine and other statutory legal acts ${ }^{11}$. Referring to the content of the term "academic integrity", as a set of ethical principles, it is important to highlight the Codes of Academic Integrity implemented (introduced) in higher education institutions (hereinafter - "HEIs"). The tendency is mediated by the borrowing of "best practices" of leading world

${ }^{8}$ Про правила етичної поведінки : Закон України Відомості Верховної Ради (ВВР), 2013, № 14, ст. 94. URL: http://zakon.rada.gov.ua/laws/show/4722-17

9 Про затвердження Державної програми щодо реалізації засад державної антикорупційної політики в Україні (Антикорупційної стратегії) на 2015-2017 роки : Постанови Кабінету Міністрів України від 29 квітня 2015 року № 265. URL: http://zakon3.rada.gov.ua/laws/show/265-2015-\%D0\%BF

${ }^{10}$ Про запобігання корупції : Закон України. Відомості Верховної Ради (ВВР), 2014, № 49, ст.2056 URL: http://zakon.rada.gov.ua/laws/show/1700-18

${ }^{11}$ Про освіту: Закон України / Відомості Верховної Ради (ВВР), 2017, № 38-39, ст.380. URL: http://zakon.rada.gov.ua/laws/show/2145-19 
higher education institutions and for the observation of requirements of Article 42 of the Law of Ukraine "On Education". The development of the program "The Fundamental Values of Academic Integrity" of the International Centre of Academic Integrity under Rutland Institute for Ethics at Clemson University, South Carolina, is a ground for the implementation of such measures. As defined in the Program, academic integrity is a commitment of the academic community, even in the face of adversity, to six fundamental values: honesty, trust, fairness, respect, responsibility, courage ${ }^{12}$. However, despite the fact that "fundamental principles of ethical conduct for public officials" are consolidated in the relevant Law of Ukraine and branch programs for the prevention of corruption of executive authorities and other entities are elaborated upon Decision of the National Agency on Corruption Prevention (hereinafter - "the NACP") dated January 19, 2017 No 31 "Methodical Recommendations on the Preparation of Anti-Corruption Programs" ", taking into account the provisions of the Law of Ukraine "On Prevention of Corruption" ", it is essential to use the similar approach - to fix the rules of ethical conduct in a particular Law of Ukraine, for example, "On the Rules of Academic Ethical Conduct, to improve the effectiveness in supporting "academic integrity". Moreover, it makes sense to elaborate "unified" methodical recommendations for the preparation of branch codes of academic integrity which would contribute to the unification of measures for ensuring academic ethics (academic ethical principles for certain entities).

Provisions on the formation of a national integrity system designed to cover all areas, including the education sector in Ukraine (the author's note), are especially noteworthy. Transparency International attempted to set the National Integrity System as a general approach to the evaluation, the discovery of corruption in Ukraine and the drafting of anti-corruption measures. It stands to mention that there is no a unified standard for the introduction of the streamlined anti-corruption system and, consequently, it complicates the process of shaping the integrity of a public servant and the system of "academic integrity".

Among the high priority measures of the promotion of "academic integrity", one can mark the first steps to the creation of the system for

12 Сацик В. Академічна доброчесність: міфічна концепція чи дієвий інструмент забезпечення якості вищої освіти?URL: http://education-ua.org/ua/articles/930-akademichnadobrochesnist-mifichna-kontseptsiya-chi-dievij-instrument-zabezpechennya-yakosti-vishchojiosviti.

13 Затверджено Методичні рекомендації щодо підготовки антикорупційних програм органів влади. URL: https://nazk.gov.ua/news/zatverdzheno-metodychni-rekomendaciyishchodo-pidgotovky-antykorupciynyh-program-organiv-vlady

${ }^{14}$ Про запобігання корупції : Закон України. Відомості Верховної Ради (ВВР), 2014, № 49, ст.2056 URL: http://zakon.rada.gov.ua/laws/show/1700-18 
prevention and detection of academic plagiarism in the higher education institutions which meets the provisions of part 8 of Article 16 of the Law of Ukraine "On Higher Education". Moreover, the building of the above system is performed within one particular institution. Thus, such a trend doesn't raise doubts about its development. However, while realizing paragraph 1 of part 1 of Article 1 of the Law of Ukraine "On Higher Education"15, which defines the autonomy of "education" institution, its self-reliance, independence towards the realization of academic freedom, research, etc., the system of prevention and detection of academic plagiarism becomes a closed system, namely, one that doesn't consider scientific achievements carried out within other HEIs. Therefore, the autonomy of the functioning of the system can't be considered as an effective one to the fullest extent.

An individual issue of the support of academic integrity, which needs resolving, is the establishment of the National Agency for Assurance of Higher Education Quality and accredited independent institutions for the evaluation and quality assurance of higher education regarding its compliance with the requirements for the system of quality assurance of higher education, compliance with international standards of higher education quality and maintenance of "academic integrity". It is also important to draw attention to the procedure of integrity verification of persons who are obtaining/or have obtained academic ranks (professor, associate professor). According to the Order of the MES of Ukraine No. 13 dated 14.01.2016 "On Approval of the Procedure for Conferment of Academic Ranks to Academic and Research Staff", there is a procedure for assignment of academic ranks. Thus, Section II sets the key criteria for the assessment of academic activity of the candidates for academic ranks among which there is: carrying out educational activity at a high level; a certificate on training/internship, participation in the international projects, top-level teaching in the national or other languages (OECD), work experience, teaching-learning and research papers, which are indexed by the relevant scientometric databases, certificates in compliance with the Common European Framework, etc. ${ }^{16}$. The correspondence of activities of a research/other official defined by the Procedure with the indicated criteria gives ground to obtain an academic rank (associate professor/professor). The above is confirmed by Section IV of the Regulation "Deprivation of academic ranks", in particular, part 1 states that deprivation of academic ranks is carried out under the procedure of their conferment and

${ }^{15}$ Про вищу освіту: Закон України / Відомості Верховної Ради (ВВР), 2014, № 37-38, ст. 2004. URL: http://zakon.rada.gov.ua/laws/show/1556-18

16 Про запобігання корупції : Закон України URL: http://zakon.rada.gov.ua/laws/ show/1700-18 
considered by the MES (it is concluded about the invalidation of the certificate of a person who has obtained an academic rank) upon a decision of the Academic Council of a higher education institution ${ }^{17}$. Therefore, there is a statutory option of the Academic Council of HEI, which has recommended the MES to uphold its decision of awarding a person with an academic rank following the certification case of an applicant and a relevant resolution, to reconsider such (own) decision. However, it is worth noting that deprivation of the person's academic rank (certificate annulment) can take place in the event of a violation of the procedure of case formation and inconsistency of the person, at the time of filing a case to the MES, with the criteria defined in the Procedure. If the violations are revealed after the approval of a decision of the Academic Council of HEI of the MES of Ukraine, it is essential to envisage the procedure of bringing HEI representatives, who were responsible for the case formation, to an academic liability. We believe that statutory consolidation of such a procedure will facilitate the carrying out of arts. 1 and 11 of the Law of Ukraine "On Higher Education" which are the basis for determination of the autonomy of a higher education institution taking into account an advanced level of its "academic integrity". Individual attention is paid to the elimination of the possibility to practice upon the HEI requirements in order to "manipulate" applicants for academic ranks because the Law arranges a special type of "academic coercion" which is mediated by the availability of provisions on academic responsibility. Considering the urgency of the issue of the application of measures of academic responsibility, its solution lies in further research results.

\section{CONCLUSIONS}

Summing up the presentation of the basic research information, it stands to focus on the importance of the use of other statutory acts, well-established concepts, categories, definitions in the Law. Primarily, the emphasis should be placed on the unified approach to the content and essence of the concepts, which are used in the Laws "On Education", "On Higher Education". The above fact is connected with the use of such terms in other statutory acts in relation to which the mentioned ones are special. At the outset, it would be expedient to define "academic integrity", "academic responsibility" etc. Being the fragment of theoretical knowledge of scholars, they would reflect that phenomenon existing in the peal practice, clear up its essence drawn a line between concepts and categories which are the subject-matter of other sciences. The theoretical ground of the concepts used in the Laws would make

17 Про запобігання корупції : Закон України URL: http://zakon.rada.gov.ua/laws/ show/1700-18 
it possible to ensure a logic nature and consistency of their use by legal practitioners. And vice versa, when there is no definition, the legislator can (as exemplified in this research) pursue a somewhat hasty implementation of rulemaking innovations. This problem subsists in the form of "swiftness" of imitating European Union countries that is mediated by a lack of time for sound scientific inquiry.

\section{SUMMARY}

The article analyzes the essence and legal significance of the concept of "academic integrity". It is conducted a comparative analysis of the essence of the concept of "integrity" in the legislation controlling the education sector in Ukraine and anti-corruption legislation. The paper establishes the statutory differences between the application of the above term and prospects of forming its generally accepted definition to use the unified approach.

\section{REFERENCES}

1. Про освіту: Закон України / Відомості Верховної Ради (ВВР), 2017, № 38-39, ст. 380. URL: http://zakon.rada.gov.ua/laws/show/2145-19

2. Про вищу освіту: Закон України / Відомості Верховної Ради (BBP), 2014, № 37-38, ст. 2004. URL: http://zakon.rada.gov.ua/laws/ show/1556-18

3. Етимологічний словник української мови: У 7 т. / Редкол. О. С. Мельничук (голов. ред.) та ін. К.: Наук. думка, 1983 Т. 6: / Уклад.: Г. П. Півторак та ін. 2012. 568 с.

4. Лис В. Про Сократа, Данила Галицького, Фернандо Магелана, Ісаака Ньютона, Шарлотту, Емілі, Енн Бронте. К. : Грані-Т, 2008, 134 с.

5. Академічна доброчесність: проблеми дотримання та пріоритети поширення серед молодих вчених : кол. моногр. / за заг. ред. Н. Г. Сорокіної, А. Є. Артюхова, І. О. Дегтярьової. Дніпро : ДРІДУ НАДУ, 2017. $169 \mathrm{c}$.

6. Україні - європейські принципи державної служби : буклет. К. : ГУДС, Центр сприяння інституційному розвитку державної служби. 2006. 7 c.

7. Про засади державної антикорупційної політики в Україні (Антикорупційна стратегія)" на 2014-2017 роки : Закон України. Відомості Верховної Ради (ВВР), 2014, № 46, ст. 2047 URL: http://zakon3.rada.gov.ua/laws/show/1699-18

8. Про правила етичної поведінки : Закон України Відомості Верховної Ради (ВВР), 2013, № 14, ст. 94. URL: http://zakon.rada.gov.ua/ laws/show/4722-17

9. Про затвердження Державної програми щодо реалізації засад державної антикорупційної політики в Україні (Антикорупційної 
стратегії) на 2015-2017 роки : Постанови Кабінету Міністрів України від 29 квітня 2015 року № 265. URL: http://zakon3.rada.gov.ua/laws/show/265$2015-\%$ D0\%BF

10. Про запобігання корупції : Закон України. Відомості Верховної Ради (ВВР), 2014, № 49, ст. 2056 URL: http://zakon.rada.gov.ua/ laws/show/1700-18

11. Сацик В. Академічна доброчесність: міфічна концепція чи дієвий інструмент забезпечення якості вищої освіти?URL: http://educationua.org/ua/articles/930-akademichna-dobrochesnist-mifichna-kontseptsiya-chidievij-instrument-zabezpechennya-yakosti-vishchoji-osviti.

12. Затверджено Методичні рекомендації щодо підготовки антикорупційних програм органів влади. URL: https://nazk.gov.ua/news/ zatverdzheno-metodychni-rekomendaciyi-shchodo-pidgotovkyantykorupciynyh-program-organiv-vlady

13. Про запобігання корупції : Закон України URL: http://zakon.rada.gov.ua/laws/show/1700-18

Information about the author: Tytska Ya. O.,

Candidate of Law, Associate Professor, Associate Professor at the Department of Administrative, Criminal Law and Procedure, International University of Business and Law 33, Fontanska Road str., Odessa, 65000, Ukraine 
DOI https://doi.org/10.36059/978-966-397-178-0/287-303

\section{CONCEPT, PROPERTIES AND PRINCIPLES OF ADMINISTRATIVE RESPONSIBILITY}

Voronin Ya. G.

\section{INTRODUCTION}

The Institute of administrative responsibility is an outstanding institution of administrative law, an important means of protecting public order, which is characterized by all the signs of legal responsibility.

The role and place of administrative responsibility in the administrative and legal space is determined by the fact that the relations of administrative responsibility, together with the relations of public administration, administrative services and administrative proceedings form the subject of administrative law. And also the essential feature of administrative responsibility consists in pragmatism of its theoretical concepts which dominating orientation is defined by a problematics of the Code of Ukraine about administrative offenses.

\section{The concept, characteristics and reasons of administrative responsibility}

The concept of administrative responsibility, its content and scope to this day remains one of the most controversial issues of Ukrainian administrative and legal science.

The activity of discussions on this legal category is largely due, firstly, to the breadth of the use of the term "administrative responsibility" in the legal, scientific, law enforcement, educational spheres and at the domestic level, and secondly, to the dual position of the legislator, who uses this term in numerous regulations, but does not give its definition ${ }^{1}$.

In fact, there is no legal definition of such a category as "administrative responsibility" in the current legislation. And all definitions of administrative responsibility are usually provided in scientific publications and have a research character.

For example, the legal encyclopedia in the article "Administrative responsibility" defines that: administrative responsibility-a type of legal responsibility of citizens and officials for the administrative offenses committed by them.

\footnotetext{
${ }^{1}$ Code of Ukraine on administrative offences. URL: http: Iwww.rada.gov.ua (access date: 08.08.2019)
} 
In the legal literature it is possible to meet such definitions:

a) administrative responsibility is the application of the offender, coercive measures (L. Koval, Y. Bytyak, V. Zui, and other);

b) administrative responsibility is the definition of restrictions on property, as well as personal benefits and interests for the Commission of administrative offenses (I. Dodin and others);

c) administrative responsibility is a set of administrative legal relations arising in connection with the application of administrative penalties to the subject of misconduct (I. Golosnichenko and others).

According to V. Kolpakov, the listed definitions lack the absence of instructions on the performance by the subjects of illegal actions of administrative coercion measures applied for their Commission, which is an essential component of any responsibility, including administrative. After all, responsibility comes only when the offender has carried out the measures of influence established by the competent person, or otherwise implemented.

Proceeding from the stated, administrative responsibility is provided by the legislation, compulsory, with observance of the established procedure, application by the competent subject concerning the persons who have committed administrative offenses of measures of influence which implementation is legally recognized.

Administrative responsibility, as well as other types of legal responsibility comes from the presence of normative, factual and documentary grounds:

- factual grounds are legal facts related to the offense, in particular, the fact of committing a misdemeanor and the fact of carrying out measures of responsibility, in addition, they include the facts of detention, inspection, filing appeals, recognition of evidence of factual data, etc;

- legal (normative) bases form norms on which act is recognized as an administrative offense (offense), measures of coercion for performance of structure of offense are defined, subjects of responsibility and jurisdiction, rules on which penalties are imposed and carried out, legality, the rights of participants of production, etc. are provided;

- procedure (documentary) grounds are procedural rules that bringing the guilty persons to administrative responsibility and documents in accordance with established requirements and the established legislation procedure, first and foremost, a Protocol on administrative offense and the decision on business about an administrative offence, and this includes certificates, statements, treatment records, etc.

There is no normative act that would contain all the legal norms that form the basis of administrative responsibility, or at least submit a list of them. 
These grounds are determined by the requirements of a significant number of legal acts: codes, individual laws, regulations, rules and other acts ${ }^{2}$.

Certain indications on their system are observed in the Code of Ukraine on administrative offences (CAO). So, in article 2 CAO established that the legislation of Ukraine on administrative offenses make:

a) the code of Ukraine on administrative offences;

b) other laws on administrative offences (such laws, for inclusion in the administrative Code, apply directly to them and in this case the provisions of the CAO apply).

In article 5 "powers of local councils on decision-making for which violation administrative responsibility is provided" fixed the right of local governments to make decisions for which violation administrative responsibility is provided.

According to it rural, settlement, city and regional councils make decisions on questions of fight against:

a) with natural disaster. The code of civil protection of Ukraine defines a natural disaster as a natural phenomenon, acts with great destructive force, causes significant damage to the territory in which it occurs, violates the normal life of the population, causes material damage;

b) epidemics. Violation of such decisions entails liability under Art. 42 "Violation of sanitary and hygienic and sanitary-antiepidemic rules and regulations";

c) epizootics. Violation of such decisions shall entail liability under art. $107 \mathrm{CAO}$ "Violation of rules concerning quarantine of animals and other veterinary and sanitary requirements".

Besides, rural, settlement and city councils can establish:

a) rules of improvement, observance of cleanliness and an order in territories of settlements. Violation of such rules shall entail liability under article 152 of the CAO "Violation of state standards, norms and rules in the field of improvement of settlements, rules of improvement of territories of settlements";

b) rules of trade in the markets. Violation of such rules shall entail liability under article 159 of the CAO "Violation of the rules of trade in the markets";

c) rules of silence in settlements and public places. Violation of such rules shall entail liability under article 182 of the CAO "Violation of the requirements of legislative and other normative legal acts concerning the protection of the population from the harmful effects of noise or the rules of

${ }^{2}$ Kolpakov V. Administrative responsibility: studies. no. / V. Kolpakov. Kyiv: Yurinkom Inter, 2008. $256 \mathrm{p}$. 
silence in settlements and public places". These provisions are correlated with the provisions of articles 26, 43 of the Law "on local self-government in Ukraine".

In addition, article 2 of the CAO contains a fundamental provision regarding administrative liability for violation of customs rules. It clearly indicates: the issue of administrative responsibility for violation of customs rules are regulated by the Customs code of Ukraine. This norm is correlated with the norms of article 487 of the Customs code of Ukraine, from which it follows that the legal support of proceedings on violation of customs rules in certain cases is carried out by the Code of Ukraine on administrative offenses ${ }^{3}$.

An example of a law which contains provisions on administrative liability, which are applied directly (not included in CAO) can serve the Law of Ukraine from 04.03.1992 "On state property privatization", which in article 29 established the administrative responsibility of officials of bodies of privatization in the form of a penalty for unfounded refusal to accept the application on privatization; violation of terms of consideration of the application on privatization; violation of conditions and order of carrying out of competition, auction, sale of shares (shares, shares); violation of the conditions and procedure for the transfer of shares of joint stock companies created in the process of privatization, corporatization.

In addition, the current legislation contains a significant number of normative documents, which establish various rules and requirements, for violation of which the administrative Code provides for administrative responsibility. This, for example, road traffic Rules, approved by the decree of the Cabinet of Ministers of Ukraine from October 10, 2001 No. 1306 (administrative responsibility for their violation is provided by article 121-129 and other Art); Temporary rules of the circulation in Ukraine of household pyrotechnic products, approved by order of the Ministry of interior, dated 23 December 2003. No. 1649 (administrative responsibility provided by article 1956 "Violation of the order of production, storage, transportation, trade and use of pyrotechnics"); "Rules of air transportation of passengers and baggage" approved by the order of the Ministry of infrastructure of Ukraine on November 30, 2012 No. 735 (administrative responsibility is provided by Art. 112 "Violation of the rules of conduct on the aircraft"). In addition, the article (art. 112) establishes liability for noncompliance by persons on the aircraft, orders of the commander of the vessel,

${ }^{3}$ Kolomoets T. Administrative responsibility: studies. benefit. Kiev: Istina, 2011. 177 p. 
who is a representative of the air carrier and is guided by the rules established by him, that is, corporate norms ${ }^{4}$.

Special attention is paid to identify and eliminate the causes and conditions conducive to an administrative offence (article 6 of the "Prevention of administrative offence"), and rule of law in this sphere (article 7 "the rule of law in the application of measures of influence for administrative offences"). In particular, such methods of ensuring the rule of law as:

- systematic control by higher authorities and officials;

- prosecutorial supervision;

- right of appeal.

Important provisions concerning the normative provision of liability for administrative offences are contained in article 8 of the CAO "Operation of the law on liability for administrative offences", which establishes that:

- prosecution is carried out according to the norms in force at the time and place of the offense;

- laws that mitigate or annul the responsibility shall be retroactive (apply to offences committed prior to their publication);

- laws that establish or strengthen liability are not retroactive;

- proceedings for misconduct are conducted on the basis of the law in force during and at the place of consideration of the case.

Important importance for ensuring legality of administrative responsibility belongs to provisions which define the circumstances excluding administrative responsibility (Art. 17), and also release from it (Art. 21, 22).

The circumstances excluding administrative responsibility are directly spelled out in Art. 17 of the CAO:

1) a state of extreme necessity is the Commission of actions with signs of administrative misconduct to eliminate the danger threatening the state or public order, property, rights and freedoms of citizens, the established order of management, if this danger in these circumstances could not be eliminated by other means and if the harm caused is less significant than the harm prevented;

2) self-defense - it acts with signs of administrative violation in the protection of state or public order, property, rights and freedoms of citizens, the established order of management wrongful assault by inflicting harm to the attacker, if it was not admitted exceeding the limits of necessary defense and excess of limits of necessary defense, the law recognizes a clear discrepancy between the protection of nature and social harmfulness of infringement.

${ }^{4}$ Code of Ukraine on administrative offences. URL: http:॥www.rada.gov.ua (access date: 08.08.2019) 
3) the state of insanity is the Commission of actions with signs of administrative misconduct by a person who could not be aware of his actions or direct them due to chronic mental illness, temporary mental disorder, dementia or other painful condition.

Exemption from administrative liability is the result of the conclusion of the subject, considering the case, about:

1) possibility of transfer of materials on an administrative offense for consideration of the public organization or labor collective in a case when character of the committed offense and the personality of the offender testifies to expediency of application to it of measures of public influence (Art. 21 $\mathrm{CAO}$ ). In this case, a person who has committed an administrative offense is released from administrative responsibility with the transfer of materials for consideration of a public organization or a labor collective. On the public measures applied to persons who committed offenses under article 51, the first part of article 129, parts first and second of article 130, articles 156, 173, 176, 177, $178-180$ Art, the owner of the enterprise, institution, organization or authorized body or Association must, not later than within ten days from the date of receipt of materials to inform the body (official) who sent the materials.

2) recognition of insignificance of a misdemeanor (Art. $22 \mathrm{CAO}$ ). In this case, the body (official) authorized to solve the case may release the offender from administrative responsibility and limit himself to an oral comment ${ }^{5}$.

Taking into account the stated provisions, it can be concluded that the signs of administrative responsibility are:

1) bringing to administrative responsibility is possible only as a result of committing an administrative offense;

2) administrative responsibility consists in application to guilty of administrative penalties. In article. $23 \mathrm{CAO}$ "The purpose of administrative penalty" it is specified that administrative penalty is a measure of responsibility;

3) the purpose of administrative responsibility is:

a) educating the person in the spirit of compliance with the laws, respect for the rules of the hostel;

b) preventing the Commission of new offenses;

4) the right to bring to administrative responsibility is provided to many subjects, among which-bodies of the state Executive power, local selfgovernment, courts (art. $213 \mathrm{CAO}$ "Bodies (officials) authorized to consider cases of administrative offenses");

5 . Kolpakov V. Administrative responsibility: studies. no./V. Kolpakov. Kyiv: Yurinkom Inter, 2008. $256 \mathrm{p}$. 
5) an act on bringing to administrative responsibility may be adopted: a) individually (judges and officials of the relevant bodies); b) collegially by voting (Executive committees and administrative commissions);

6) the legislation establishes a special procedure for bringing to administrative responsibility (drawing up a Protocol, collecting and evaluating evidence, making a decision, etc.);

7) the rules governing administrative responsibility are contained in various legal acts: a) codes; b) laws; c) rules. Rules can be approved by the Cabinet of Ministers, Executive authorities, established by decisions of local councils and even corporate acts.

\section{Principles of administrative responsibility}

Principle (from lat. principium-the beginning of, basis) - this the main the initial position any teachings, science, worldview and the like.

The principles of administrative responsibility are the main provisions enshrined in the Constitution and other laws of Ukraine, on which the procedure for bringing perpetrators to administrative responsibility is based.

The principles of administrative responsibility include:

- rule of law;

- legalities;

- expediencies;

- validities;

- inevitabilities;

- timeliness's;

- justices;

- humanism's;

- the individualization of punishment;

- correspondence of guilt and punishment, and the like.

The rule of law is a priority in the rule of law state. This principle is that administrative responsibility in Ukraine and the procedure for bringing to administrative responsibility is based on constitutional principles and legal presumptions, which are conditioned by the implementation and operation of the principle of the rule of law in Ukraine. The Constitution of Ukraine has the highest legal force, laws and other normative legal acts are adopted on the basis of the Constitution of Ukraine and must comply with it (part 2 of article 8 of the $\mathrm{CU}$ ).

The principle of the rule of law is, in its essence, the principle of natural law as a set of ideal, spiritual and just concepts of law. Recognition of the constitutional principle of the rule of law means that the laws of the state, as well as their application, must comply with the law as a measure of universal and equal freedom and justice for all. In addition, the laws should 
limit the arbitrariness of both individuals, legal entities and the state for the common good.

The principle of the rule of law means that the freedom of citizens should be ensured by such a legal order, when no one forces to do something that is not stipulated by the law, and the person, his rights and freedoms are recognized as the highest value. The rule of law also means that the government forms a law, but the law is the basis of life and existence of the state represented by its bodies, officials and other organizations ${ }^{6}$.

The principle of legality is, firstly, that administrative responsibility comes only for those acts that are provided by law, secondly, to bring to administrative responsibility have the right only provided by law competent authorities, thirdly, public administration bodies when deciding on bringing the guilty person to administrative responsibility should be guided by the law and exercise their powers within the competence provided by law. The principle of legality of administrative responsibility is fixed in Art. 7 of the CAO.

The principle of expediency. The content of the concretizing decision, taken on the basis of administrative discretion, does not in all cases follow directly from the normative prescription. This objectively determines the existence of the principle, which makes it easier for the authorized subject to find the right solution. So, art. 21 of the Cao stipulates that a person who commits an administrative violation may be released from administrative liability with the transfer of materials for consideration of public organization or labor collective, if given the nature of the offense and the offender to him appropriate to apply a measure of societal impact. According to article 22 CAO body (official), authorized to solve the case, can release the offender from administrative responsibility and be limited to an oral remark at the insignificance of administrative misconduct. In expediency of release of the offender from administrative responsibility on the grounds of insignificance of his offense the various circumstances mitigating responsibility, including the conditions allowing to reach the educational and preventive purposes without application of measures of administrative influence, in particular, the fact of absence at the violator of steady antisocial installations can convince.

The principle of validity is that arbitrary bringing of a person to administrative responsibility is not allowed. Law enforcement bodies shall establish the fact of Commission of administrative offense, and also establish other circumstances of the case having value for qualification of

\footnotetext{
${ }^{6}$ Kolomoets T. Administrative coercion in the public law of Ukraine: theory, experience and practice: dis. ... doctor. Yuri. Sciences : 12.00.07. NATs. Ministry of internal Affairs. Kharkiv, 2005. $454 \mathrm{p}$.
} 
administrative offense and individualization of administrative responsibility. Also, the choice of a specific measure of administrative punishment should be based on a thorough study of the case materials and taking into account the mitigating and aggravating circumstances of the case. The principle of reasonableness is not directly enshrined in the alms, but follows from its provisions. Thus, article 251 of the Cao stipulates that evidence in the case on administrative offence is any evidence on the basis of which in accordance with the law, the body (official) sets the presence or absence of administrative violation, guilt of the person in its Commission and other circumstances relevant to the proper resolution of the case ${ }^{7}$.

The principle of inevitability assumes the inevitability of administrative responsibility for the person who committed an administrative offense. The inevitability of administrative responsibility depends to a greater extent on the well-established work of law enforcement agencies, on the professionalism of employees authorized to prosecute and apply sanctions. An administrative offence to which the state has not responded causes serious damage to the state. Impunity for offenders encourages them to commit new offences and sets a negative example for other vulnerable individuals.

The principle of timeliness of administrative responsibility means the possibility of bringing the offender to justice within the Statute of limitations, i.e. the period of time not too distant from the fact of the offense. The Statute of limitations for the application of administrative penalties to a person is regulated by article 38 of the administrative Code, which stipulates that an administrative penalty may be imposed no later than two months from the date of its detection, except when cases of administrative offenses in accordance with the administrative Code are subordinated to the court (judge). If cases on administrative offenses according to the administrative Code or other laws are subordinated to court (judge), penalty can be imposed not later than in three months from the date of Commission of an offense, and at the continuing offense - not later than in three months from the date of its detection. Administrative penalties for committing a corruption offense may be imposed within three months from the date of detection, but not later than one year from the date of its Commission. In case of refusal in excitation of criminal case or closure of the criminal case, but if the violator signs an administrative offence, the administrative penalty may be imposed not later than one month from the date of taking decision about refusal in excitation of criminal case or its closure.

${ }^{7}$ Mikolenko A. Administrative process and administrative responsibility in Ukraine: studies. no. Kharkiv: Odyssey, 2010. 365 p. 
After the expiration of the limitation period, the possibility of imposing an administrative penalty is excluded. It is also necessary to note the fact that the Statute of limitations under article 38 of the CAO are absolute, that is, they cannot be continued by anyone, and their omission, regardless of the reasons, clearly excludes the imposition of an administrative penalty. However, practice shows another thing-the Statute of limitations for bringing to administrative responsibility are violated. And the reason here not only of incompetence, negligence, neglect of the body (official) deciding on the case, which violates the principle of legality and timeliness of administrative responsibility, but in ignorance of the legislation on administrative responsibility by the offender and the lack of proper control by the public over the activities of the administrative courts that are entitled to bring the perpetrators to administrative responsibility.

The principle of justice is that the legislator, providing for a sanction for an administrative offense, must proceed from the degree of public danger of this illegal act.

Principle of humanism. Its essence is respect for the dignity and rights of the person. Proceeding from the principle of humanism, officials are prohibited, under the guise of formal procedural regulations, to humiliate the dignity of a person, to infringe on his slightest needs and interests. Law enforcement exists only to realize the rights and obligations of citizens. And means, as it is known, should correspond to the purpose-to safe existence and development of the person in society. The choice of procedural forms that do not correspond to this goal hinders or even hinders the implementation of the ideas of humanism. In addition, humanism is a criterion for the correctness of the decision, and also manifests itself in circumstances that exclude the proceedings on an administrative offense (for example, the insanity of a person, a state of extreme necessity). The exact truth of the case must be judged according to moral principles.

The principle of individualization of punishment requires a correspondence between the degree of exposure to the elected offender and the degree of public danger of administrative misconduct. The application of this principle is closely related to the individualization of administrative responsibility depending on the degree of public danger of the offense and the characteristics of the offender. This principle is not enshrined in the CAO, however, follows from its provisions. For example, part 2 of art. $33 \mathrm{CAO}$ fixes that at imposition of administrative penalty the nature of the committed offense, the personality of the violator, degree of its fault, property status, the circumstances mitigating and aggravating responsibility are considered.

The principle of conformity of guilt and punishment requires that when choosing a specific measure of administrative punishment, all the 
circumstances of the offense and the identity of the offender are taken into account. Implementation of the specified principle is promoted by fixing in the legislation of possibility of a choice of administrative penalty from several possible (alternative sanctions) or the specific size of collecting within the provided minimum and maximum (rather certain sanctions), proceeding from character of an offense and the person guilty.

The principle is explained as follows: what is more harmful than an offense, a more significant type of administrative penalty should be applied by the competent authorities (officials). For an example of implementation in practice of this principle it is necessary to specify that violation of rules of behavior on the aircraft, namely, non-performance by the persons who are on the aircraft, orders of the commander of the vessel involves the prevention or imposition of the penalty from one to five non-taxable minima of the income of citizens (part 1 of Art. 112 of CAO). At the same time, willful disobedience of a lawful order or demand of the employee of militia, the member of public formation on protection of a public order and state border, the soldier because of their participation in the protection of public order punishable by a fine from eight to fifteen non-taxable minimum incomes of citizens or public works for a period from forty to sixty hours, or correctional labor for a term of one to two months with assignment of twenty percent of earnings, and if the circumstances of the case, given the person, the application of these measures will be deemed insufficient, - administrative arrest for up to fifteen days (part 1 of article 185 of the $\mathrm{CAO}$ ).

\section{Delineation of administrative responsibility from other types of legal responsibility}

Administrative responsibility cannot be perceived differently than in the context of other types of responsibility, because the synthesizing principle here is the need to be responsible for their own actions, illegal actions, to take the blame for their consequences. Although there are common features that are inherent in any type of legal liability, administrative liability, at the same time, differs from other types of legal liability. The criteria of differentiation include:

a) grounds for bringing to administrative responsibility;

b) a circle of subjects which are allocated with the right of initiation and consideration of cases on administrative offenses; establishment of administrative responsibility;

c) legal consequences;

d) procedural procedure;

e) sanctions. 
Administrative liability is dissociated from criminal liability on the following grounds:

1) administrative responsibility comes for Commission of an administrative offense which structure is defined both by laws (administrative Code, the Customs code of Ukraine, the Law of Ukraine "About Association of citizens"), and by-laws (the decision of local governments). Criminal liability occurs for the Commission of a crime, the composition of which is determined exclusively by the norms of the Criminal code of Ukraine;

2) a wide range of subjects of public administration have the right to initiate cases of administrative offences, as well as the right to consider such cases. The right to initiate criminal cases is vested exclusively with the bodies of inquiry and preliminary investigation, defined by the criminal procedure code of Ukraine, and the Prosecutor's office, and the right to review exclusively the courts. As for the subjects who establish legal liability, unlike criminal liability, which is established exclusively by the Verkhovna Rada of Ukraine, administrative liability is established by other subjects of public administration (local self-government bodies);

3) only individuals shall be held criminally liable, and both individuals and legal entities shall be held administratively liable;

4) bringing a person to administrative responsibility and applying administrative sanctions to him does not lead to such consequences as a criminal record, which further manifests itself in certain restrictions on her legal personality (for example, free travel outside Ukraine);

5) administrative responsibility is realized both in extrajudicial, and in a judicial order, criminal-only in judicial;

6) bringing a person to administrative responsibility takes place in a short time and under a simplified procedure (the possibility of imposing an administrative penalty at the place of Commission of an illegal act, without drawing up a Protocol on an administrative offense-article 258 of the CAO).

It should also be noted that criminal liability takes precedence over administrative liability. In part 2 of article 9 of the Code of Ukraine on administrative offences, it is noted that administrative responsibility for offences under the administrative Code occurs if these violations by their nature do not entail criminal liability in accordance with the law ${ }^{8}$.

Administrative responsibility is dissociated from civil law on the following grounds:

1) in the Institute of administrative responsibility there is a presumption of innocence, and in civil-a presumption of guilt;

\footnotetext{
${ }^{8}$ Kolomoets T. Administrative responsibility: studies. benefit. Kiev: Istina, 2011. 177 p.
} 
2) the purpose of bringing to administrative responsibility is education of the person and prevention of Commission of offenses further and by other persons, civil-first of all, compensation of damage;

3) administrative responsibility falls within the competence of public administration bodies and their officials, while civil liability falls within the competence of the courts;

4) measures of civil liability public relations, as a rule, are protected at the expense of the property of the perpetrator in order to restore the former property status of the injured party, and measures of administrative responsibility, as criminal, are directed against the person of the offender;

5) normative grounds of administrative and civil liability are regulated by different legislation-administrative and civil. Differences on the actual bases consist in specificity of concrete structures of administrative and civil offenses-object of illegal encroachment, legal consequences of their Commission.

The object of civil illegal actions are property relations, which are protected in court. The object of administrative illegal actions is anotherpublic relations in the field of public administration, which are protected both in court and out of court by the authorities of the relevant bodies and officials.

Administrative liability differs from civil liability and the consequences of an unlawful act. If for administrative offenses such element as illegal consequence (material damage) is not always obligatory, the structure of a civil offense, as a rule, provides it;

6) administrative liability occurs mainly out of court in a short time or even at the place of Commission of the offense, but the civil law cannot take place without the appropriate application of the interested party to the court with a claim. Terms of bringing to civil liability, as opposed to administrative, - up to 3 years, they can be interrupted, lengthened, updated and the like.

There are significant similarities between administrative and disciplinary responsibility. They have about the same degree of public danger. Characterized by such traits as guilt, unlawfulness, criminal liability.

Evidence of their closeness is the position of the legislator, who in article 15 of the CAO establishes that person's subject to disciplinary statutes, for administrative offenses are subject to disciplinary responsibility.

It is supported by the explanations of the Plenum of the Supreme Court of Ukraine "on the practice of consideration by courts of complaints against decisions in cases of administrative offenses", which States that bringing officials and citizens to disciplinary responsibility for their offenses does not exclude the application of administrative penalties for these violations and does not exempt them from the obligation to compensate for the harm caused by them. 
At the same time, the urgent need is to determine the features on which administrative responsibility differs from disciplinary, namely:

1) the main feature that determines all other differences between administrative and disciplinary responsibility is their different legal nature. It finds its expression in the fact that the duty to comply with the rules, for violation of which administrative responsibility is provided, relies on the relevant subjects authoritatively. The obligation to adhere to the rules, for violation of which disciplinary responsibility is provided, is assumed by the relevant subjects voluntarily.

Thus, the nature of administrative responsibility is public law. It occurs in violation of generally binding rules, which are established by the public administration. Such rules are legal expression of generalizations about socially useful behavior of subjects of public relations. They are contained in laws and operate throughout the country, regardless of the territorial, institutional, ethnic, property, demographic, production and other characteristics of the regions and their population. By means of these rules strengthening of legality, prevention of an offense, education of citizens in the spirit of exact and steady observance of the Constitution and laws of Ukraine, respect for the rights, honor and advantage of other citizens, to rules of cohabitation, conscientious performance of the duties, responsibility before society is carried out. And also protection and protection of the rights and freedoms of citizens, property, the constitutional system of Ukraine, the rights and legitimate interests of enterprises, institutions and organizations, the established law and order.

Obligatory rules are subject to execution by all subjects, regardless of personal ideas about the appropriateness of certain actions. Their violation implies legal responsibility (administrative responsibility).

The nature of disciplinary responsibility is civil. It arises on the condition that the parties have entered into an employment contract and come to an agreement on mutual rights and obligations that will be performed voluntarily. An integral part of such agreements is the obligation to comply with the internal labor regulations (the rules of discipline established in the organization) and bear responsibility for its violation. It should be defined that a disciplinary offence is a breach of discipline that operates within a particular organizational structure. In this context, discipline is a set of regulations governing the obligations of the parties to labor relations. The legal encyclopedia gives such definition of a disciplinary offense: illegal non-performance or improper performance by the employee of the labor duties for what to it disciplinary punishment can be applied. Thus, administrative and disciplinary responsibility are different in nature objects of encroachment. Thus, the objects of encroachment of an 
administrative offense are characterized by a national scale and importance (constitutional system, established law and order, property, rights of citizens). And objects of encroachment of a disciplinary offense are localized by the employment contract within the limits of concrete organizational structure. The General object here will be the discipline of labor. Direct objects-its individual elements. For example, the rules of working time, organization of the labor process at the enterprise, rules for the use of the property owner, rules for admission, rules of disclosure, rules for compulsory medical examination and the like.

It should be noted that in some cases, labor duties and General duties (administrative and legal) may coincide. This applies to drivers, trade workers. In such cases the violations committed by them are both disciplinary and administrative;

2) administrative responsibility is carried out under the legislation on administrative offences, which currently acts as a separate legislative branch. Here the definition of an administrative offense is given, specific structures are described, jurisdiction on consideration of cases is established, procedural questions are in detail regulated. Disciplinary responsibility does not form a separate branch of legislation. It is directly or indirectly expressed in the normative material of administrative, labor, correctional labor and other branches of law. This, for example, the labor Code of Ukraine of December 10, 1971 (articles 40, 41, 139, 140, 147); Criminal Executive code of Ukraine of July 11, 2003 (articles 68, 82 and others); laws of Ukraine "on labor protection" of October 14, 1992 (article 19); "on collective agreements and agreements" of July 1, 1993 (articles 17, 18, 19); statutes and regulations on discipline (for example, "Disciplinary Statute of the civil protection service" of March 5, 2009, "Disciplinary Statute of the State service for special communications and information protection of Ukraine" of September 4, 2008, "Disciplinary Statute of internal Affairs bodies" of February 22, 2006).

The Central place among the listed normative acts belongs to the labour Code. It serves as a guideline for all other acts that establish disciplinary responsibility.

In contrast to clearly written out compositions of administrative offenses, the compositions of disciplinary offenses are defined in the most General form. Thus, the Disciplinary Statute of the Armed Forces of Ukraine recognizes as a disciplinary offense violation of military discipline or public order. The disciplinary Statute of the internal Affairs bodies recognizes as a disciplinary offense the failure or improper performance by a person of the rank and file or commanding staff of the service discipline;

3) administrative responsibility differs from the disciplinary characteristic of the subject who committed the illegal act. The subject of an administrative 
offense is a sane person who has reached the age of 16 and has performed the administrative offense described in the law. Thus, the main features of the subject of administrative misconduct are age, sanity, guilt. And the subject of disciplinary misconduct can only be a person who is in an employment relationship with the employer. Such a person may be both an adult and a minor. The main feature of the subject of disciplinary misconduct is the stay in the employment relationship with the employer. Absence of this sign excludes recognition of the person as the subject of a disciplinary offense;

4) administrative offences differ from disciplinary offences by the characteristics of the subject who has the right to consider them and make decisions. Thus, the subject of disciplinary cases is the head of the team in which the offender works. Between them (the head and the violator of discipline) necessarily there are steady organizational communications of type "the chief-the subordinate". And the subject of consideration of cases on administrative offenses is the carrier of the functional power which powers are accurately defined and fixed in the legislation. There are no stable organizational ties between him and the offender.

\section{CONCLUSIONS}

Therefore, administrative responsibility is a special type of legal responsibility. Administrative liability has a number of specific features that distinguish it from other types of legal liability. Traditionally, legal responsibility is associated with the use of measures of state coercion, it is considered as a reaction to the offense provided for by the sanctions of legal norms, as the implementation, application and implementation of sanctions. The application of measures of legal responsibility entails for the offender burdensome consequences of property, moral, personal or other nature, which he is obliged to undergo and actually endure. Thus, the offender "holds accountable" to the state for misconduct.

\section{SUMMARY}

The article reveals the concept, features and grounds of administrative

responsibility principles of administrative responsibility, differentiation of administrative responsibility from other types of legal responsibility

\section{REFERENCES}

1. Kolomoets T. Administrative responsibility: studies. benefit. Kiev: Istina, 2011. $177 \mathrm{p}$.

2. Kolomoets T. Administrative coercion in the public law of Ukraine: theory, experience and practice: dis. ... doctor. Yuri. Sciences : 12.00.07. NATs. Ministry of internal Affairs. Kharkiv, 2005. 454 p. 
3. Mikolenko A. Administrative process and administrative responsibility in Ukraine: studies. no. Kharkiv: Odyssey, 2010. 365 p.

4. Administrative responsibility / Rel. ed. L. Bachilo, N. Kameneva; Institute of state and law of Russian Academy of Sciences ; Acad. legal UN-T. Moscow, 2001. $150 \mathrm{p}$.

5. Kolpakov V. Administrative responsibility: studies. no. / V. Kolpakov. Kyiv: Yurinkom Inter, 2008. 256 p.

6. Course of administrative law of Ukraine: Textbook / V. Kolpakov, O. Kuzmenko, I. Pastukh. Kyiv: Yurinkom Inter, 2012. 808 p.

7. Code of Ukraine on administrative offences. URL: http: Iwww.rada.gov.ua (access date: 08.08.2019)

\section{Information about the author:}

Voronin Ya. G.,

Doctor of Law, Professor,

Professor at the Department of Administrative,

Criminal Law and Procedure, International University of Business and Law 37-A, 49 HGD str., Kherson, 73040, Ukraine 


\section{EVOLUTION OF THE HIGHER EDUCATION ISSUES IN THE INTERNATIONAL TREATIES}

\section{Hromovenko K. V.}

\section{INTRODUCTION}

The improvement of regulation of the aspects of educational relations has now become an extremely important issue of the domestic legal doctrine. Such a scientific analysis cannot be complete without studying the processes of development of international mechanisms in the field of education, in particular, in the formation of international law of the classical period, which seems relevant to the modern legal doctrine. The purpose of this Article is to define the specifics of the regulation of the aspects of higher education in bilateral and multilateral international legal acts of XIX - XX centuries.

To achieve it, it is necessary to solve the scientific tasks of analyzing and comparing the content of relevant agreements, searching for common features or subjects of regulation in them, and determining the specificity of their emergence, taking into account global social, political and legal factors. Among domestic specialists, such domestic authors as B.V. Babin, M.V. Buromensky, V.G. Butkevych, O.O. Grinenko, A.I. Dmitriiev, V.V. Mytsyk ${ }^{1}$, etc. paid attention to the issues of the development of sources of international law in the period preceding the modernity, at the same time the educational issues were not practically raised in their works.

The importance of the format of international regulation of cooperation in the field of education in bilateral treaties is due to the rapid growth of the number of these agreements in the nineteenth century, which have received in comparison with the previous period a significant diversity in the subject matter and regulatory mechanisms. For instance, a number of bilateral interstate treaties of the 19th century with Asian countries directly focused on certain issues of the organization of education, including higher education. In particular, Article 18 of the Treaty of Peace, Amity, and Commerce, between the United States of America and the Chinese Empire of 3 July 1844 (the Treaty of Wangxia) established the right for the officials and citizens of the USA located in China, to «employ scholars» for «teaching any languages of the Empire and for assistance in literary works». Article 10 of the Treaty of

\footnotetext{
${ }^{1}$ Babin B. Legal Statute and Perspectives for Indigenous Peoples in Ukraine / Borys Babin, Olena Grinenko and Anna Prykhodko // Indigenous, Aboriginal, Fugitive and Ethnic Groups Around the Globe. L. : IntechOpen, 2019. P 161-177.
} 
Amity and Commerce (the Harris Treaty) between the United States and Japan on 29 July 1858 established the right of the Japanese Government to exchange the «scientific men» with the United States.

The Treaty between the USA and China of 1868 (the Burlingame Treaty of 1868) regulated the issue of education even more thoroughly. In particular, Article 7 of this Act states that the citizens of the USA may enjoy all the privileges of public educational institutions that are under the control of the Chinese Government and, based on reciprocity, Chinese citizens may enjoy all the privileges of public educational institutions that are under the control of the Government of the USA.

Under these privileges, the Treaty provided for the granting of «most privileged nations» in both states. Moreover, the Treaty allowed the citizens of the USA to establish and maintain schools in China in places where foreigners are allowed to live, and accordingly, Chinese citizens were granted similar privileges and immunities in the United States. And the level of such «schools» was not determined by the Treaty, obviously, they could also have a format of higher ones.

The mentioned educational norms of the agreements between the USA and China were interestingly continued in the first half of the 20th century. In particular, the matter concerns the implementation of the Boxer Protocol, an act signed on September 7, 1901, between the Government of Imperial China and eight allied states (Austria-Hungary, Great Britain, Italy, Germany, Russia, the USA, France, and Japan) on payment by China of huge indemnity (18000 tons of silver or 333 million of US dollars) to the winners of the Boxer Rebellion within forty years. The USA received $7.32 \%$ of these payments ${ }^{2}$.

This Treaty was already perceived as clearly unfair at that time, and in 1906 President Edmund J. James of the University of Illinois proposed to US President T. Roosevelt a plan to establish a programme to educate Chinese students in the United States. He wrote that «a nation that will succeed in educating young Chinese of the current generation will be one that will get the most benefit from the incurred losses due to the moral, intellectual, and commercial influence» on China. T. Roosevelt supported this plan and addressed an annual message to the US Parliament with a proposal to finance such a training of Chinese students at the expense of the indemnity that the USA receives from China under the Boxer Protocol; this decision was made on the basis of 17 million dollars that the USA was to receive from China respectively ${ }^{3}$.

\footnotetext{
${ }^{2}$ Boxer Protocol ; URL: https://en.wikipedia.org/wiki/Boxer_Protocol\#The_clauses

3 Boxer Indemnity Scholarship ; URL: https://en.wikipedia.org/wiki/Boxer_Indemnity_ Scholarship
} 
The programme was started since 1909 by establishing selection, initial training, and transportation of Chinese students to the USA. For this training, since April 2011, under this funding, the United States of America opened a preparatory school in Peking - Tsinghua College, which in the next was developed for studying at a four-year preparatory programme and postgraduate training, and became Tsinghua University since 1929.

Since 1924, the China Foundation has been operating in the United States of America, and under this programme, it provided funds to the China Institute in New York, founded in 1926. In total, until 1929, up to 1300 Chinese students received higher education within the framework of the Boxer Indemnity Scholarship programme in the USA. A similar programme was founded in Great Britain (a little later than in the USA), which was to receive from China $11.25 \%$ of the Boxer Indemnity amount ${ }^{4}$.

In 1924 during the Soviet-Chinese negotiations, the issue of Chinese students' education at Soviet universities at the expense of the Boxer Indemnity was also raised ${ }^{5}$. Though in Article 11 (approved after these negotiations) of the Agreement concerning General Principles for the Settlement of the Questions Between the Union of Soviet Socialist Republics and the Republic of China on May 31, 1924, the USSR formally refused to receive the Boxer Indemnity without any conditions, in the Declaration of the parties, added to the present Agreement, it was noted that the Russian part of the Boxer Indemnity «after satisfaction of all past obligations» will be directed «exclusively and completely to the formation of the fund for the improvement of the Chinese people's education». The distribution of resources of this fund should be implemented by a special commission of three persons, two of whom were appointed by the Government of China and the third - by the USSR. The prescription of Article 15 of the Treaty of Friendship between Persia and the Russian Socialist Federal Soviet Republic on February 26, 1921, is also interesting in this context. According to this prescription, Russia gave the property and the territory of Russian religious missions in this country to Persia on condition of their further use for «cultural and educational institutions».

It is also worth providing the Agreement between China and Japan on Detailed Arrangements for the Execution of the Treaty for the Settlement of Outstanding Questions Relative to Shantung (with Annex. Agreed Terms of Understanding and Notes Exchanged) of December 1, 1922. In Article 7 of

${ }^{4}$ Boxer Indemnity Scholarship (United Kingdom) ; URL: https://en.wikipedia.org/wiki/ Boxer_Indemnity_Scholarship_(United_Kingdom)

5 Boxer Indemnity Scholarship ; URL: https://en.wikipedia.org/wiki/Boxer_Indemnity_ Scholarship 
this Agreement, which regulated the transfer of a number of Chinese territories to Japan, the Government of Japan was assigned to the secondary school («Ariake - mashi») and the higher school for girls («Mikasa - mashi») on the relevant Chinese territory. In addition, the Agreement provided for the granting of a number of facilities for the needs of the Commercial University and guaranteed the further operation of the Chinese Public School in the former German possession of Kiao-Chao in China ${ }^{6}$. The Agreement in the form of Exchange of Notes between Germany and China regarding the Restoration of the State of Peace dated 20 May 1921 has also got a significant meaning for the regulation of education. This act defined the rights of Chinese students in Germany; the Government of Germany was to provide every possible assistance to such students in their enrolment in German universities and in their pre-diploma internship placement ${ }^{7}$.

At the end of the nineteenth century and at the beginning of the twentieth century, the aspects of guaranteeing education, including higher education, continued to be reflected in bilateral interstate treaties also in other regions of the world, in particular, on issues related to colonial wars. Thus, Article 8 of the Treaty of Peace Between the United States of America and Spain of 10 December 1898 regulated the transfer of Spanish public property in Cuba, Puerto Rico, Guam, and the Philippines, and established that the peaceful possession and use of public property by the relevant municipal, public and private entities are preserved; this norm has certainly been extended to the educational institutions. Article 9 of this Agreement preserved the right of local residents to continue their own professional activities, and Article 10 of the Treaty of 1898, among other things, established the right of intellectual property for scientific works, previously legalized in the indicated territories by Spain.

These norms of the Treaty of 1898 have been successfully applied to the oldest university in Asia, the Pontifical and Royal University of Santo Tomas, which was founded in 1611 in Manila under the Royal Charter of Philip III, confirmed by Pope Innocent $\mathrm{X}$ in 1645 and continued working under American jurisdiction as the Catholic University of the Philippines (59). The Peace Treaty of Vereeniging, between the South African Republic and the Orange Free State, on the one side, and the United Kingdom on the other side,

\footnotetext{
${ }^{6}$ Agreement between China and Japan on Detailed Arrangements for the Execution of the Treaty for the Settlement of Outstanding Questions Relative to Shantung (with Annex. Agreed Terms of Understanding and Notes Exchanged) signed at Peking, December 1, 1922 [№ 559] ; URL: https://treaties.un.org/doc/Publication/UNTS/LON/Volume\%2027/v27.pdf

${ }^{7}$ Agreements between Germany and China regarding the Restoration of the State of Peace. Pekin May 20, 1921. [№ 261] ; URL: https://treaties.un.org/doc/Publication/UNTS/LON/ Volume\%209/v9.pdf
} 
of 31 May 1902 in Article 5 guaranteed teaching of Dutch in schools of Transvaal and the Orange River Colony at the request of parents or pupils.

After the First World War, the issue of higher education has sometimes been raised in bilateral treaties as well as in unilateral acts of states of international importance; this has usually concerned the provision of education to ethnic minority groups in geographically altered states and overcoming the consequences of regional and local conflicts. As an example, it is worth mentioning the bilateral Agreement for the Purpose of Executing and Completing the Polish-Danzig Convention of 9 November 1920, signed on 24 October 1921. In its Article 228, it was defined that the Parties will conclude a separate agreement to determine the ways and limits of mutual recognition of certificates issued by schools and institutions of higher education, other diplomas, and certificates in the territory of both Parties of the Agreement ${ }^{8}$.

Albania in the Declaration concerning the Protection of Minorities in Albania of 2 October 1921 stipulated in Article 5 that the citizens of the country belonging to racial, religious or linguistic minorities shall establish and use the educational institutions; Article 6 regulated the teaching of minority languages as well as the education in minority languages in public institutions in Albania. The Protocol and Additional Article Regarding the Settlement of the Question of Western Hungary, signed in Vienna on 13 October 1921, contained the measures of the Hungarian Government concerning the «pacification» of the West of the country. This Protocol obliged the students who took part in the riots to report to universities and schools within ten days of the announcement of the special Government proclamation; the students, who evaded such a reporting, shall be expelled.

Bilateral agreements concluded with the Holy See (the Vatican City) and individual states with a significant proportion of the Catholic population were of particular importance for streamlining the higher education issues. In fact, such agreements reflected a medieval understanding of the supranational authority of the Church in the regulation of educational issues, but in the 20th century, their subject was primarily spiritual rather than secular higher education.

The Lateran Pacts between the Vatican City and Italy of 1929 are a prime example of such bilateral acts, in particular, the Lateran Treaty of 11 February 1929, Article 16 of which guarantees inviolability and tax immunities for papal institutions in the territory of Italy, including the Gregorian University,

\footnotetext{
${ }^{8}$ Agreement for the Purpose of Executing and Completing the Polish-Danzig Convention of November 9, 1920. Signed at Warsaw, October 24, 1921 [№ 2699] ; URL: https://treaties.un.org/ doc/Publication/UNTS/LON/Volume\%20116/v116.pdf
} 
Lombard College, the Bible, Pontifical Oriental, and Archaeological institutions and the Russian Seminary. In addition, Article 18 of this Treaty guarantees the students the free access to the «artistic and scientific treasures» of the Vatican City, while preserving the right of the Holy See to regulate the corresponding access of the public.

The Concordat between the Holy See and Italy, concluded at the same time as this Treaty, regulates the aspects of Catholic spiritual education in this country very thoroughly. According to Article 3 of the Concordat, the students of theology, who in the last two years of study are preparing for obtaining the priestly rank, may be granted a postponement in military service until the age of 26. Article 26 of the Concordat regulated in detail the activity of church structures, including the seminaries, established the guarantees of their existence by the state.

In addition, the Concordat also affected the secular Italian education, because according to its Article 36, the teaching of «Christian doctrine within the framework established by the Catholic tradition» in higher schools was to be implemented by means of the programme agreed between Italy and the Vatican City, and professors and other persons, who were to carry out this teaching, were obliged to obtain permission from the church authorities, confirmed by a special certificate. The church authorities had the right to revoke the certificate, which meant that the right to teach was revoked; the textbooks for the relevant teaching had to be approved by the church authorities.

According to Article 38 of the Concordat of 1929, the nomination of professors of the Catholic University of the Sacred Heart and the Academy of the Immaculate Conception of the Virgin Mary, which is dependent on it, should be the subject of agreement (nihil obstat) with the Vatican City regarding the moral and religious qualities of candidates. According to Art. 40 of this Act, the doctorate in theology, donated by the faculty that is acting with the support of the Holy See, will be determined by the Italian state, as well as the diplomas issued by the schools of paleography, archives and diplomatic documents based in the Library and Archives of the Vatican City. The key is Article 39 of this Act, according to which the universities, large and small diocesan, inter-diocesan or regional seminaries, academies, colleges, and other spiritual and cultural Catholic institutions will continue to operate in Italy in the exclusive dependence on the Holy See, without any interference in their activities by the Italian public educational authorities.

Also, it is worth mentioning the provisions of the additional Agreement between the Holy See and the Roumanian Government of 30 May 1932 Regarding the Interpretation of Article IX of the Concordat that was approved between them on 10 May 1927. Article 5 of this Agreement regulated the 
issues of the use of church property in Transylvania concerning the establishment of foundations for the support of students and teachers of educational institutions of the respective Catholic Diocese.

Article 7 of the Agreement of 1932 regulated the transfer of lands, buildings and adjoining constructions of the University of Cluj, which were in the ownership of the Roumanian state, to the full possession to another university, while its Article 9 regulated the status of the church adjoining this educational institution, where the monks were engaged in educating of the Catholic Order of Piarists. An annex to the Agreement contained the Statutes of the Council of the Catholic Diocese of Alba-Iulia, according to which the General Assembly of the Council should include the professors of theological seminary and university professors as well as the teachers of academic schools located in the Diocese ${ }^{9}$.

The Concordat concluded between the Holy See and the German Reich on 20 July 1933 cannot be ignored either. According to the norms of Article 14 of this act, the Church «as a rule» had the autonomous right to appoint the spiritual officials, including the teaching posts. At the same time, this Article of the Concordat laid down the requirements for persons, who were to be engaged in educational activities, to hold a German citizenship, to have a certificate (a diploma) of completion of German higher education and to have studied philosophy and theology for at least three years at a German state university, a church academic college, or a Papal higher school in Rome ${ }^{10}$.

Article 19 of the Concordat pointed out that the Catholic faculties of theology at state universities in Germany were to be maintained and that their interaction with the church organs was to be further regulated by the protocols to the Concordat concluded in accordance with the church law, while the uniforms at these faculties, established by the state, were to conform to the «general spirit» of such a regulation, taking into account a number of instructions approved by the Holy See and mentioned in the Concordat.

In addition, Article 20 of the Concordat enshrined the right of the Church to establish theological and philosophical colleges for the training of clergy; if no public funds were spent on these colleges, they were to depend solely on the church organs. This Article of the Concordat also included the foundation, management, and administration of seminaries and dormitories for the seminarians; for tax purposes, such dormitories were recognized as church institutions ${ }^{11}$.

${ }^{9}$ Agreement Regarding the Interpretation of Article IX of the Concordat of May 10th 1927, between the Holy See and the Roumanian Government, signed at the Vatican, May 30th, 1932 [№ 4719] ; URL: https://treaties.un.org/doc/Publication/UNTS/LON/Volume\%20201/v201.pdf

${ }^{10}$ Concordat between the Holy See and the German Reich signed on 20 July 1933 ; URL: http://www.newadvent.org/library/docs_ss33co.htm

${ }^{11}$ Concordat between the Holy See and the German Reich signed on 20 July 1933 ; URL: http://www.newadvent.org/library/docs_ss33co.htm 
According to Article 21 of Concordat of 1933, the Catholic religious regulations must be taught in Germany, including in higher schools, in accordance with the principles of the Catholic Church. At the same time, there was a requirement to foster patriotic, civic and social consciousness during the religious education. The curriculum and textbooks for religious teaching were to be determined in Germany by agreement with the supreme ecclesiastical authority (but not by this authority itself as the Concordat of 1929 with Italy envisaged). Also, the supreme ecclesiastical authority in Germany was given the right to control the educational process «in harmony with the authority of the educational institution».

According to Article 22 of the Concordat, the bishopric and the Governments of the German states had to make deals on the personalities of teachers of religious subjects; the bishops had the right to dismiss such teachers for both teaching and moral qualities. Article 23 of this Act guaranteed the continuation of existing Catholic educational institutions and the possibility of opening new ones, while Article 25 granted the right to open the educational institutions to religious orders and congregations.

However, in the period between the First and the Second World Wars, the aspects of higher education in bilateral international agreements were regulated not only on the issues of religious education. For example, the InterSchool Convention concluded between Estonia and Latvia on 17 February 1934; although it mainly concerned secondary education, Article 5 of the Convention defined the levels of requirements for teachers, according to which, those persons, who had the right (including the respective higher education) to teach in a school in Latvia, had to obtain the right to teach in a Latvian-speaking school in Estonia and vice versa.

Also during this period, bilateral agreements covered the involvement of higher educational institutions in the interstate exchange of official publications. For instance, the Agreement in the form of Exchange of Notes between the Government of the United States of America and the Estonian Government Constituting an Agreement for the Exchange of Official Publications of 6 December 1938, is worth noting. In particular, the Smithsonian Institution, as the key research and educational organization of the USA, became the institution responsible for such an exchange on the part of this country under the mentioned Agreement (on the Estonian side this function was performed by the National Library of the country). While on the US side the publications of the authorities (but also the annual reports of the Smithsonian Institution) were to be provided first of all to Estonia, the monthly publications of the Estonian Institute of Economic Research, academic publications and lecture schedules of the University of Tartu and Tallinn University of Technology were to be provided to the USA from Estonia. 
Thus, the analysis of interstate agreements of the XIX and the first half of the $\mathrm{XX}$ centuries proves that there were a few special acts on educational issues between the countries during this period, and the aspects of higher education were usually one of the subjects of regulation in them, which, above all, did not have a key role. As an exception, the Agreement concerning Scientific, Scholastic and Artistic Relations Between the Republic of Poland and the Kingdom of Yugoslavia on 2 December 1931 should be mentioned.

The preamble to the Agreement, as a basis for its endorsement, referred to the necessity of implementing the Pact of Friendship and Cordial Collaboration of 1926 between these countries in the field of «mutual intellectual cooperation» and stated that the relevant scientific and educational relations between the countries should contribute to «rapprochement of the two nations in view of their racial and linguistic affinity» ${ }^{12}$.

According to Articles 1 and 2 of the Agreement of 1931, the Technical Commission was to study all the aspects of scientific and educational relations between the two countries and provide proposals on their development. This Commission was divided into two sub-commissions, one in Belgrade and the other one in Warsaw, which were to be headed by the Ministers of Education of the two sides respectively. Each of the sub-commissions was to be comprised of four members, including one delegate from the Ministry of Foreign Affairs, two delegates from the Ministry of Education and one delegate from the sub-commission of the other side of the Agreement.

The members of the sub-commissions, except for a foreign subcommission, were appointed by the parties for a period of three years, the chairpersons of the sub-commissions and their deputies were elected annually, and the meeting of the sub-commissions was to be held at least once a year; the sub-commissions themselves determined their own rules of procedure. At the same time, according to Article 5 of the Agreement of 1931, the subcommissions could directly address to each other all the issues that were within their competences for the decision-making by the Government of Poland or Yugoslavia, respectively. According to Article 4, the subcommissions had the following powers:

- to organize more frequent contacts between the representatives of higher education of the Parties, with the promotion of the widest possible study of geography and history of another nation participating in the Agreement;

- to introduce, through special regulatory and organizational procedures, the comparability of the academic qualifications and student assessments in

${ }^{12}$ Agreement concerning Scientific, Scholastic and Artistic Relations Between the Republic of Poland and the Kingdom of Yugoslavia. Signed at Warsaw, December 2, 1931. [№ 3207] ; URL: https://treaties.un.org/doc/Publication/UNTS/LON/Volume\%20139/v139.pdf 
order to encourage the citizens of one side of the Agreement to attend courses in another country and to be admitted to the examinations without undue hindrance, bearing in mind that the access to certain specialties for the foreigners may be legally restricted by the state concerned;

- to simplify the exchange of pupils and students on the most favourable conditions and to organize the exchange of teachers in higher education;

- to organize the vacation activities and the camps for young people and cooperation between the student associations;

- to organize the exchange of scientific publications, to simplify and initiate the relations between the scientific institutions and the centres of national education.

At the same time, such agreements did not become widespread among the states of modernity in the first half of the 20th century.

The evolution of the regulation of the organization of higher education can be seen in multilateral international treaties. It can be claimed that certain issues of the organization of higher education were for the first time regulated at the level of collective agreements from the 19th century. In particular, in the acts of the Vienna Congress of 1815 , despite the lack of general norms in the field of regulation of education, much attention was paid to the status of the University of Cracow (the Jagiellonian University).

This educational institution, founded in May 1364 by King Casimir III the Great with the permission of Pope Urban V, was mentioned in Article 10 of the Final Act (Treaty) of the Congress of Vienna of June 9, 1815, according to which the constitution of the Free City of Cracow should, among other things, reflect the status of the «academy» of this city according to articles 7, 15, 16 and 17 of the Additional Treaty relative to Cracow, which had the similar effect as the Final Act (Treaty).

The said Additional Treaty relative to Cracow («The Free, Independent, and Strictly Neutral City of Cracow with its Territory») was signed in Vienna between Austria, Prussia, and Russia on 21 April 1815. According to Article 13, the property of the former Duchy of Warsaw, which was created on the territory of the Free City of Cracow, must belong to the city and constitute one of its financial sources. At the same time, the income from such property was to be used for «support of the academy and other literary institutions and mainly for the improvement of public education».

In addition, according to Article 15 of this Treaty, the buildings and the libraries owned by the "Academy of Cracow», its land property and the invested capital, together with all the privileges that it received, shall continue to be assigned to this university. Moreover, taking into account the position of the three states that shared the Duchy of Warsaw between themselves, the 
right to enter and study at this university was to be guaranteed to the population of their Polish provinces that were close to Cracow ${ }^{13}$.

Also, the status of the Jagiellonian University was regulated by the initial version of the Constitution of the Free City of Cracow, which was signed on May 3, 1815, by authorized representatives of the three states that divided Poland. According to Article 11 of this international legal act, the Assembly of Representatives of the Free City included three Doctors of Faculties appointed by the University ${ }^{14}$.

However, during the first ten years of these treaties, the privileges of the university were decreasing, primarily because of the support of its leadership of the pro-Polish position in the authority of the Free City, the supervisory bodies over its activities were established, and three states gradually prohibited their own subjects from entering this educational institution.

Also noteworthy is another act of the Vienna Congress, namely the Federative Constitution of Germany, signed by representatives of the sovereign German states of that time on 8 June 1815. According to parts 3 and 4 of Article 12 of this international act, the four free German cities (Bremen, Hamburg, Lübeck, Frankfurt) were to establish a single judicial body, the Supreme Court; but every person, who was a party to the proceedings of such a tribunal, was entitled to demand that the case be submitted from that tribunal to «a law faculty belonging to a foreign [German] university». This mention of universities as an alternative to the Supreme Court of the Free Cities is not surprising, considering that the signatories of this Federative Constitution from Lübeck and Frankfurt titled themselves in the Treaty as Doctors of Law.

Later on, Article 6 of the General Act of the Berlin Conference on West Africa, signed by the majority of the then states on 26 February 1885, laid down their duty «to protect and promote» «all kinds of ... scientific institutions» which are founded with the aim of improving the «moral and material welfare» of the population of West Africa, destroying slavery and «educating the natives so that they may understand and appreciate the benefits of the civilization».

The following act, the Brussels Act on these issues of 2 July 1890, contained no norms concerning the education or the enlightenment in Africa,

${ }^{13}$ Additional Treaty relative to Cracow, between Austria, Prussia, and Russia of 21st April (3d May) 1815 [Act № III]. ; URL: https://en.wikisource.org/wiki/Final_Act_of_the_Congress_ of_Vienna/Act_III

${ }^{14}$ Constitution of the Free City of Cracow. Done at Vienna the 3d day of May, 1815 ; URL: https://en.wikisource.org/wikiFinal_Act_of_the_Congress _of_Vienna/Constitution_of_the_Free_ City_of_Cracow 
but the Convention on the Revision of the said Acts of 1885 and $1890^{15}$, approved on 10 September 1919, between Belgium, the United Kingdom of Great Britain, Italy, Portugal, the United States of America and Japan at SaintGermain-en-Laye, in Article 11, part 2, contained the provisions similar to those of the General Act of Berlin concerning the scientific and educational activities in Africa «to assist the indigenous peoples in their progress and civilization». At the same time, these norms in practice did not particularly contribute to the establishment of higher educational institutions by the colonial powers.

In Central Africa, for example, the first institution of the appropriate level (Fourah Bay College, present-day Sierra Leone) was founded by Britain in 1827, but the school became an affiliated college of the English Durham University in 1876 and only awarded the first scientific degree in Africa in 1878 (it was not until 1967 that this college became a full-fledged university). The colleges founded in South Africa in 1829 and 1866 respectively became the University of Cape Town and the Stellenbosch University only in April 1918. The Makerere University in Uganda was established in 1922, and the formation of the University of Khartoum in Sudan was preceded by its activities as a college since 1902. The rest of the universities and even colleges in Africa were actually founded after World War II and in the context of decolonization.

The issue of organization of higher education was mentioned to a certain extent in international intellectual property law, which began to develop rapidly in the last decades of the XIX century. In particular, the Convention Concerning the Creation of An International Union for the Protection of Literary and Artistic Works of September 9, 1886 (the Berne Convention) is interesting not only by regulating the relations important for the educational process in the field of scientific works and periodicals (Articles 4 and 7). In Article 8, it establishes the freedom of use of the fragments (citations) of the works protected by copyright in the publications with educational and scientific orientation, as well as in the anthologies.

These provisions were confirmed in Article 10 of the Berlin Act, Revised Berne Convention for the Protection of Literary and Artistic Works ${ }^{16}$ and in Article 10 of the Rome Act of July 2, 1928. In addition, the Rome Act in Art. 2bis further granted the states parties the right at the national level to determine the order of printing and distribution of lectures and speeches as a

\footnotetext{
${ }^{15}$ Babin B. Legal Statute and Perspectives for Indigenous Peoples in Ukraine / Borys Babin, Olena Grinenko and Anna Prykhodko // Indigenous, Aboriginal, Fugitive and Ethnic Groups Around the Globe. L. : IntechOpen, 2019. P 164.

${ }^{16}$ Berlin Act, Revised Berne Convention for the Protection of Literary and Artistic Works, of November 13, 1908 ; URL: http://global.oup.com/booksites/content/9780198259466/15550017
} 
special form of implementation of copyrights, with the presumption of freedom of such printing, while preserving the exclusive right of the author to publish the lectures in the form of their collections (courses).

Other collective agreements of that period also contained certain exceptions from various areas of international relations to facilitate scientific and educational activities. As an example, the International Convention for the Protection of Birds Useful to Agriculture, Art. 7 of which did not extend the relevant restrictions on catching such birds to activities related to scientific activity ${ }^{17}$. Thus, the relevant specialized work of the Faculties of Natural Sciences was objectively simplified.

Also, during this period, interstate research institutes are beginning to be formed under international agreements. For example, according to the Convention of 7 July 1905 for the Creation of an International Institute of Agriculture, a designated institution began to function in Rome, consisting of a general assembly and a standing committee, whose members were delegated by the states parties to the Convention.

Despite its broad powers in the field of organizing the scientific research on the issues of statistical, technical and economic information related to the farming, crop production, and animal husbandry, agricultural trade and relevant pricing, the International Institute of Agriculture cannot be considered as an international educational institution, because the Convention of 1905 did not provide for the training of personnel there. At the same time, the approach itself to the possibility of forming international research institutions is important for the evolution of the attitude in international law towards the problems of higher education.

The issue of protection of the educational institutions was raised at the turn of the nineteenth and twentieth centuries in the international humanitarian law, too. In particular, the Regulations concerning the Laws and Customs of War on Land, added to the Convention (II) with Respect to the Laws and Customs of War on Land of 29 July 1899, in Article 27, among other things, proposes to take all the necessary means for the protection during the sieges and bombardments of «the buildings that serve for the purposes of science», the institutions of higher education undoubtedly belong to this category. The party to the conflict controlling these buildings should mark them with the special visual signs, which were to be provided in advance. Moreover, according to Article 56 of these Regulations, the property of the educational and scientific institutions, both public and other ones, shall be equated to the private property. This means that any intentional seizure, destruction or

${ }^{17}$ Bowman M. J. The 1902 Convention for the Protection of Birds in Historical and Juridical Perspectiveal / Michael J. Bowman // Ardeola. 2014. Vol. 61. № 1. P. 175. 
damage of such institutions is prohibited and must be prosecuted by the party to the conflict that has taken control of these institutions.

These norms are fully reproduced in Articles 27 and 56 of the Regulations concerning the Laws and Customs of War on Land annexed to the Convention (IV) respecting the Laws and Customs of War (the Hague Convention IV) of October 18, 1907. Besides, the Hague Convention IX of 1907 in Article 5 provided the protection of «buildings which serve for the purposes of science» from bombardments from the sea, and the Hague Convention XI of 1907 in Article 4 prohibited the seizure of the scientific vessels (apparently also those ones belonging to the universities).

A number of mentions of the aspects of the organization of higher education can be seen in the Treaty of Peace of Versailles of June 28, 1919, signed by a significant number of states, the relevant norms were very variable and fragmented. For example, according to the Treaty concerning the French Occupation of Saarland, Part III, Section IV, Chapter I, § 14, the relevant occupation authorities were empowered to establish the technical educational institutions in the mining industry. In Art. 134 Germany renounced the right of ownership for the colleges, which it had in Shanghai, in favour of France and China.

A group of norms of the Treaty of Versailles was aimed at restricting military education in Germany, including higher education. Thus, according to part 3 of Article 175, the officers, demobilized after the reduction of the army, were forbidden to participate in the training process, and according to part 5 of Article 194, it was forbidden to provide military training to the officers and the privates of the merchant fleet. According to Article 177 of this Agreement, two months after the entry into force of the Treaty of Versailles, Germany was to reduce the number of military schools in the quantity corresponding to the needs of the recruitment of the officers in the authorized units, and no more than one school per one type of troops, with a limited number of students. All the military academies «and similar institutions» were to be closed in Germany.

Moreover, according to Article 177 of the Treaty of Versailles, all the educational institutions and universities in Germany «shall have no right to deal with any military matters», in particular, with the teaching or training of their own pupils or teachers in the field of military arts or weapons possession. In addition, all the educational institutions and universities in Germany were prohibited from having any connection with the military ministries or any other military authority. Special measures of supervision over the compliance of Germany with the above prescriptions on the part of the victorious states were fixed in articles 211 and 213 of the Treaty of Versailles. 
Article 247 of the Treaty of Versailles of 1919 is of particular interest, under which Germany undertook to provide the Catholic University of Leuven with the manuscripts, incunabula, printed books, maps, and objects from the collections that «correspond in quantity and value to similar objects destroyed during the burning of the Library of the Catholic University of Leuven by Germany» within three months after receiving through the Reparation Commission the relevant request. The details of the appropriate replacement intended for the Belgian university were to be determined by the Reparation Commission.

It is worth adding that the Catholic University of Leuven was opened in 1425 by Pope Martin V upon request of John IV, Duke of Brabant, and operated continuously until World War I, except for the period of 1797-1834, caused by the French intervention. The seizure of Leuven by German troops in 1914 was accompanied by the burning of half of the city, during which the university library burned down along with 300 thousand publications and a thousand incunabula, a large number of unique manuscripts. The mentioned destruction of the university library during the First World War was actively used in anti-German propaganda ${ }^{18}$.

In addition to these fragmented requirements, the Treaty in Versailles did not contain any general prescriptions for the regulation of education; the only general norm found in this area is the provision of p. 6 of Article 427 of this Treaty, under which the states must impose restrictions on the work of young people of both genders to enable them to continue their education. Moreover, paradoxically, the Covenant of the League of Nations, approved during the Versailles Peace Conference on 28 April of 1919, generally contained no norms on education and did not enshrine the powers of the League, giving priority to political, economic and legal issues.

It is important to trace the impact on relations in higher education and on the conventions that were concluded in the first half of the twentieth century under the auspices of the International Labour Organization (hereinafter the ILO) established in 1919. Although none of these conventions was specifically devoted to the educational issues, a number of relevant agreements contained the norms that were significant for the organization of the educational processes, including in higher education. In particular, a number of the ILO conventions, which set a minimum age for the workers, contained the clauses on the possibility of working for the purpose of training of persons who are students of vocational education institutions.

\footnotetext{
${ }^{18}$ Catholic University of Leuven (1835-1968) ; URL: https://en.wikipedia.org/wiki/Catholic University_of_Leuven_(1835-1968)
} 
In particular, Article 3 of the ILO Convention No. 5 Fixing the Minimum Age for Admission of Children to Industrial Employment of 1919 contained such norms; Art. 3 of the ILO Convention No. 7 Fixing the Minimum Age for Admission of Children to Employment at Sea of 1920 (for work on the educational or training vessels), Art. 3 of the ILO Convention No. 10 concerning the Age for Admission of Children to Employment in Agriculture of 1921, Art. 2, p. «b» of the ILO Convention No. 33 concerning the Age for Admission of Children to Non-Industrial Employment, 1932, Art. 3 of the ILO Convention No. 58 Fixing the Minimum Age for the Admission of Children to Employment at Sea of 1936 (Revised) and Article 3 of the ILO Convention No. 59 Fixing the Minimum Age for Admission of Children to Industrial Employment of 1937 (Revised). Part 2 of Article 3 of the ILO Convention No. 13 concerning the Use of White Lead in Painting, 1921 and part 1 of Article 2 of the ILO Convention No. 17 concerning Workmen's Compensation for Accidents, 1925 also contained the mentioning of the industry training.

Also, a number of the ILO conventions of that time provided for the possibility of not including the persons, related to the training, by relevant prescriptions. Thus, the prescriptions of the ILO Convention No. 22 concerning Seamen's Articles of Agreement, 1926, and the Convention No. 23 concerning the Repatriation of Seamen, 1926, did not apply to the cadets, the students on the training vessels and the students under the training agreements. The above-mentioned ILO Convention No. 17 of 1925 in paragraph «d» of part 2 of Article 2 allowed the national legislator not to extend its requirements to «the persons of intellectual work».

Such exceptions were also included in the «insurance» conventions of the ILO approved in 1933, such as the ILO Convention No. 35 concerning Compulsory Old-Age Insurance for Persons Employed in Industrial or Commercial Undertakings, in the Liberal Professions, and for Outworkers and Domestic Servants; the ILO Convention No. 36 concerning Compulsory Old-Age Insurance for Persons Employed in Agricultural Undertakings; The ILO Convention No. 37 concerning Compulsory Invalidity Insurance for Persons Employed in Industrial or Commercial Undertakings, in the Liberal Professions, and for Outworkers and Domestic Servants; the ILO Convention No. 38 concerning Compulsory Invalidity Insurance for Persons Employed in Agricultural Undertakings; The ILO Convention No. 39 concerning Compulsory Widows' and Orphans' Insurance for Persons Employed in Industrial or Commercial Undertakings, in the Liberal Professions, and for Outworkers and Domestic Servants, and the ILO Convention No. 40 concerning Compulsory Widows' and Orphans' Insurance for Persons Employed in Agricultural Undertakings. 
Although all these conventions in part 1 of Article 2 provided for the extension of «non-physical work, including apprentices», in part 2 of this Article they allowed the states not to extend their action to «apprentices», to «any non-physical workers engaged in the activities which are generally regarded as free professions» and to «workers who, during their own training, give lessons or carry out paid work while preparing for a profession that corresponds to the purpose of such training» ${ }^{19}$.

At the same time, it is interesting to note that the ILO Convention No. 30 concerning the Regulation of Hours of Work in Commerce and Offices of 1930 did not include any reference to the educational institutions among the detailed list of possible forms of work outside the industry, indicating only about «the institutions ... where the workers are primarily engaged in clerical work» (p.»b «, part 1 of Article 1$)$.

In addition, p. «b» of part 1 of Article 11 of the ILO Convention No. 29 concerning Forced or Compulsory Labour, 1930, provided for the restrictions on the involvement of «school teachers and pupils» in this kind of work, but not in relation to the teachers and students of higher education. The ILO Convention No. 53 concerning the Minimum Requirement of Professional Capacity for Masters and Officers on Board Merchant Ships of 1936 should be considered as the first convention that actually provided for a particular educational level for a certain professional activity. This act in Article 4 provided for the special examinations and the existence of professional training for the candidates for posts, although the Convention No. 53 also did not require higher education.

So, we should come to the following conclusions. The increase in the number of references to the aspects of higher education in bilateral international acts, noticeable in the second half of the XIX century, should be connected with the penetration of European standards in this field in the Asian states such as China and Japan. At the same time, the guarantees of the realization of educational rights and the preservation of educational institutions in the territories that changed their status are characteristic of the interstate agreements of the nineteenth and twentieth centuries concluded after the colonial wars.

Attention to the organization of higher education can be traced in the new national states of Europe that emerged according to the results of the First World War. The concordats concluded with the Holy See in the first half of the 20th century are of special importance in the organization of higher education in the states with a significant part of the Catholic population. The

19 Convention concerning Compulsory Invalidity Insurance for Persons Employed in Agricultural Undertakings № 38 ; 29 June, 1933 ; URL: https://www.ilo.org/dyn/normlex/en/f?p= NORMLEXPUB:12100:0::NO:12100:P12100_INSTRUMENT_ID:312183:NO 
further reflection of higher education issues in the international treaties of the second half of the twentieth and twenty-first centuries should be the subject of separate research.

The international agreements of the XIX and the first half of the $\mathrm{XX}$ centuries as a whole did not ensure the formation of holistic international legal institutions in the field of higher education. The references to higher education in the acts of the Vienna Congress of 1815 referred to individual practical circumstances that the states parties had to resolve. The prediction of the mechanisms of education and enlightenment in the collective agreements concerning West Africa of the late nineteenth century did not lead to the development of the higher education systems in these territories.

\section{CONCLUSIONS}

The reflection of the higher education aspects in the conventions concerning the humanitarian law and the protection of intellectual property was certainly of practical importance, but fragmented and specialized. The Treaty of Peace of Versailles of 1919 put the educational issues into the format of reparations for Germany and limited the development of its military system, while the statutory acts of the League of Nations and the International Labour Organization, in general, avoided the issues of educational relations. However, the realities of life have led to the reflection of individual educational issues in the conventions approved under the auspices of the ILO in 1919-1939. The definition of the role of these norms in the next formation of modern international legal institutions in the field of higher education should become a subject for new scientific research.

\section{SUMMARY}

This Article is devoted to the evolution of the international legal provision of the regulation of educational relations in bilateral and multilateral international agreements of the XIX and XX century. Special attention was devoted to the issues of the coherent international legal framework of the treaties with Asian states, of the agreements targeted to the defense of the minorities' educational rights and of the concordats with Holy See. Particular attention is paid to the role of higher education in the universal peace agreements, the impact of agreements in the fields of intellectual property protection, of labour and social rights, and of humanitarian law on the educational relations is highlighted.

\section{REFERENCES}

1. Additional Treaty relative to Cracow, between Austria, Prussia, and Russia of 21st April (3d May) 1815 [Act № III]. ; URL: https://en.wikisource.org/ wiki/Final_Act_of_the_Congress_of_Vienna/Act_III 
2. Agreement between China and Japan on Detailed Arrangements for the Execution of the Treaty for the Settlement of Outstanding Questions Relative to Shantung (with Annex. Agreed Terms of Understanding and Notes Exchanged) signed at Peking, December 1, 1922 [№ 559] ; URL: https://treaties.un.org/doc/Publication/UNTS/LON/Volume\%2027/v27.pdf

3. Agreements between Germany and China regarding the Restoration of the State of Peace. Pekin May 20, 1921. [№ 261] ; URL: https://treaties.un.org/doc/Publication/UNTS/LON/Volume\%209/v9.pdf

4. Agreement concerning Scientific, Scholastic and Artistic Relations Between the Republic of Poland and the Kingdom of Yugoslavia. Signed at Warsaw, December 2, 1931. [№ 3207] ; URL: https://treaties.un.org/doc/ Publication/UNTS/LON/Volume\%20139/v139.pdf

5. Agreement for the Purpose of Executing and Completing the PolishDanzig Convention of November 9, 1920. Signed at Warsaw, October 24, 1921 [№ 2699] ; URL: https://treaties.un.org/doc/Publication/UNTS/LON/ Volume\%20116/v116.pdf

6. Agreement Regarding the Interpretation of Article IX of the Concordat of May 10th 1927, between the Holy See and the Roumanian Government, signed at the Vatican, May 30th, 1932 [№ 4719] ; URL: https://treaties.un.org/doc/Publication/UNTS/LON/Volume\%20201/v201.pdf

7. Babin B. Legal Statute and Perspectives for Indigenous Peoples in Ukraine / Borys Babin, Olena Grinenko and Anna Prykhodko // Indigenous, Aboriginal, Fugitive and Ethnic Groups Around the Globe. L. : IntechOpen, 2019. P 161-177.

8. Berlin Act, Revised Berne Convention for the Protection of Literary and Artistic Works, of November 13, 1908 ; URL: http://global.oup.com/ booksites/content/9780198259466/15550017

9. Bowman M. J. The 1902 Convention for the Protection of Birds in Historical and Juridical Perspectiveal / Michael J. Bowman // Ardeola. 2014. Vol. 61. № 1. P. 171-196.

10. Boxer Indemnity Scholarship ; URL: https://en.wikipedia.org/wiki/ Boxer_Indemnity_Scholarship

11. Boxer Indemnity Scholarship (United Kingdom) ; URL: https://en.wikipedia.org/wiki/Boxer_Indemnity_Scholarship_(United_Kingdom)

12. Boxer Protocol ; URL: https://en.wikipedia.org/wiki/Boxer_Protocol\# The_clauses

13. Catholic University of Leuven (1835-1968) ; URL: https://en.wikipedia.org/wiki/Catholic_University_of_Leuven_(1835-1968)

14. Concordat between the Holy See and the German Reich signed on 20 July 1933 ; URL: http://www.newadvent.org/library/docs_ss33co.htm 
15. Constitution of the Free City of Cracow. Done at Vienna the 3d day of May, 1815 ; URL: https://en.wikisource.org/wiki/ Final_Act_of_the_Congress_ of_Vienna/Constitution_of_the_Free_City_of_Cracow

16. Convention concerning Compulsory Invalidity Insurance for Persons Employed in Agricultural Undertakings № 38 ; 29 June, 1933 ; URL: https://www.ilo.org/dyn/normlex/en/f?p=NORMLEXPUB:12100:0::NO:1210 0:P12100_INSTRUMENT_ID:312183:NO

17. Convention concerning Compulsory Invalidity Insurance for Persons Employed in Industrial or Commercial Undertakings, in the Liberal Professions, and for Outworkers and Domestic Servants № 37; 29 June, 1933 ; URL: https://www.ilo.org/dyn/normlex/en/f?p=NORMLEXPUB: 12100:0::NO:12100:P12100_INSTRUMENT_ID:312182:NO

18. Convention concerning Compulsory Old-Age Insurance for Persons Employed in Agricultural Undertakings № 36 ; 29 June, 1933 ; URL: https://www.ilo.org/dyn/normlex/en/f?p=NORMLEXPUB:12100:0::NO:1210 0:P12100_INSTRUMENT_ID:312181:NO

19. Convention concerning Compulsory Old-Age Insurance for Persons Employed in Industrial or Commercial Undertakings, in the Liberal Professions, and for Outworkers and Domestic Servants № 35 ; 29 June, 1933 ; URL: https://www.ilo.org/dyn/normlex/en/f?p=NORMLEXPUB: 12100:0::NO:12100:P12100_INSTRUMENT_ID:312180:NO

20. Convention concerning Compulsory Widows' and Orphans' Insurance for Persons Employed in Agricultural Undertakings № 40; 29 June, 1933; URL: https://www.ilo.org/dyn/normlex/en/f?p=NORMLEXPUB:12100:0:: NO:12100:P12100_INSTRUMENT_ID:312185:NO

21. Convention concerning Compulsory Widows' and Orphans' Insurance for Persons Employed in Industrial or Commercial Undertakings, in the Liberal Professions, and for Outworkers and Domestic Servants № 39 ; 29 June, 1933 ; URL: https://www.ilo.org/dyn/normlex/en/f?p=NORMLEXPUB: 12100:0:: NO:12100:P12100_INSTRUMENT_ID:312184:NO

22. Convention concerning Forced or Compulsory Labour № 29; 28 June, 1930 ; URL: https://www.ilo.org/dyn/normlex/en/f?p=NORMLEXPUB: $12100: 0::$ NO:12100:P12100_INSTRUMENT_ID:312174:NO

\section{Information about the author: Hromovenko K. V., Ph.D., Docent,} Rector of the International Humanitarian University Odesa, Ukraine 
Publishing house "Liha-Pres"

9 Kastelivka str., Lviv, 79012, Ukraine 44 Lubicka str., Torun, 87-100, Poland

Printed by the publishing house "Liha-Pres"

Passed for printing: September 27, 2019.

A run of 150 copies. 